


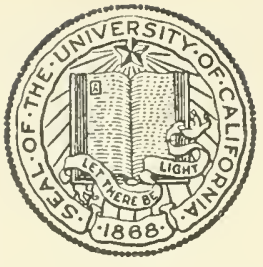

THE LIBRARY

OF

THE UNIVERSITY

OF CALIFORNIA

IOS ANGELES 
UNTVERGITY OF CATIFORNLA

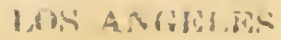





\section{IN THE LAND OF THE BORA}

"God send us all safe back to Monmouthshire"

SMOLLETT 



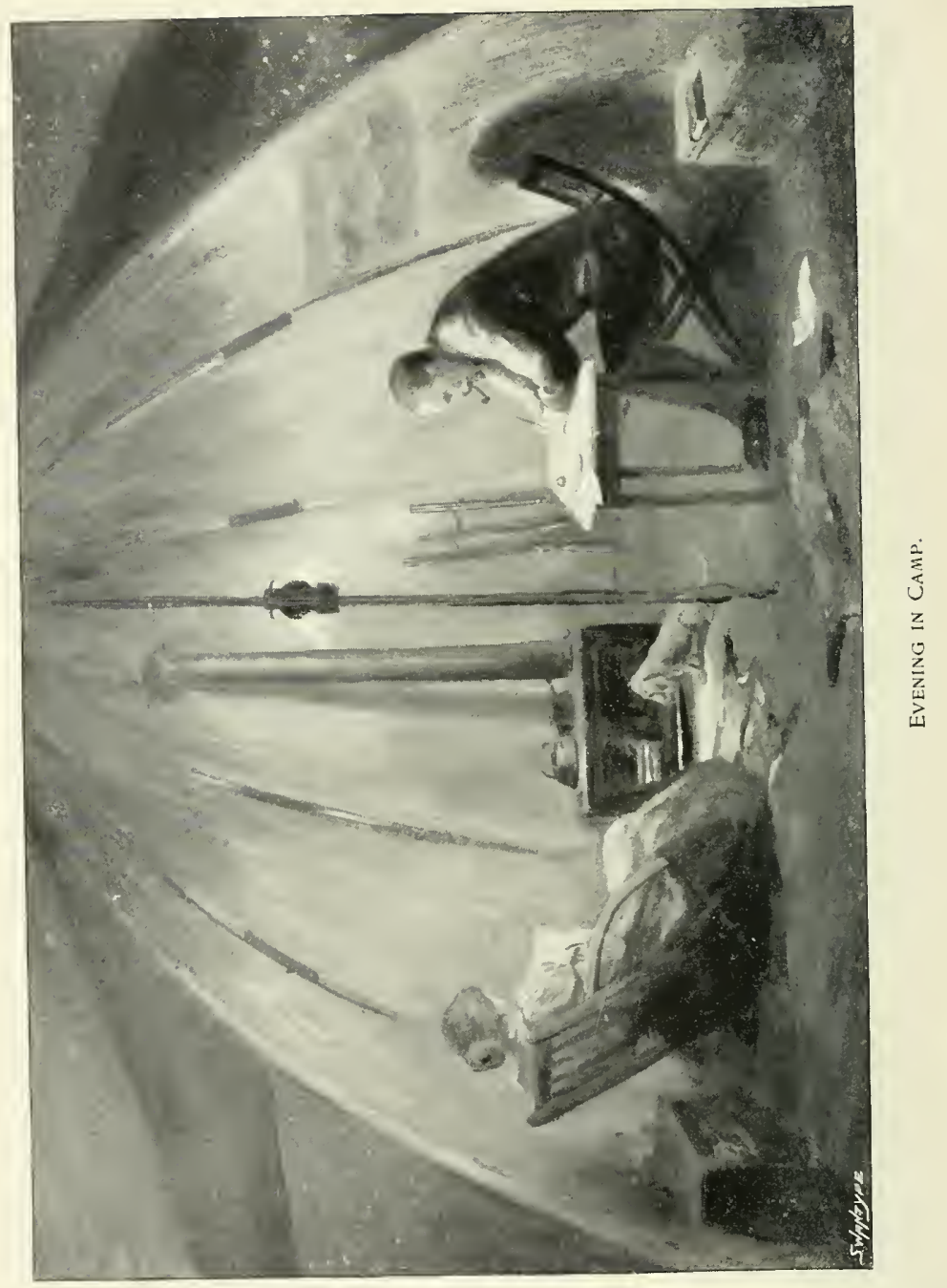




\title{
I N
}

\section{THE LAND OF THE BORA}

OR

\section{CAMP LIFE AND SPORT IN DALMATIA AND \\ I'HE HERZEGOVINA}

$$
1894-5-6
$$

\author{
BY \\ "S N A F F L E" \\ AUTHOR OF “GUN, RIFLE. AND HOUND," ETC.
}

ILLUSTRATED BY HARRY DIXON

FROM SKETCHES BY THE AUTHOR

L O N D ON

KEGAN PAUL, TRENCH, TRÜBNER \& CO., LT?" PATERNOSTER HOUSE, CHARING CROSS ROAD 
(The rights of translation and of reproduction are reserved.) 
DED I A T E D

(EY PERMISSION)

TO HIS ROYAL HIGHNESS THE DUKE OF PARMA, AS A POOR EXPRESSION

OF THE AUTHOR'S LOYALTY. 



\section{PREFACE.}

"The fault of most books of travel is that the writer delays to tell us his experiences until he has got accustomed to his new surroundings; in his solicitude to supply information he forgets the salient points which struck him on his first arrival, and therefore cannot communicate them to us stay-at-homes; and they are the very things we want to know. Moreover, he omits those details in which the difference really lies, and also the means by which he accomplished his journey, which to those who would follow his footsteps are absolutely essential. To find a volume of travel free from these faults is a distinction in itself " (James Payn).

It has been a great comfort to me to come across the above opinion, which I did when about half of the following pages was written. I can at all events claim to have fulfilled two of Mr. Payn's 
requirements. The impressions of our wanderings were invariably recorded within a few hours; and the entire book, with few exceptions, was written under canvas-a fact which I may urge as some excuse for shortcomings. Again, I think I may fairly claim to have omitted neither "those details wherein the difference really lies," nor the means by which I accomplished my journey. Indeed, before I had, so to say, the imprimatur of so well-known an authority, I feared I had perhaps been too prolix in these matters.

In the following pages I have made free use of a number of my own articles which have appeared during the last two years in various periodicals; and I here desire to return thanks to the proprietors of the Field, Live Stock Journal, Rod and Gun, and Shooting Times, for their kind permission to do so.

Corfu,

October, 1896. 


\section{IN THE LAND OF THE BORA.}

strengtnened my inclination towards it, even in spite of the fact that the editor of the abovenamed periodical, writing privately, said that the sport was very indifferent. Unfortunately for himself, he went on to give his reason for saying so, which was that it was free. Now, I have in the past enjoyed, and hope in the future to 
viii PREFACE.

requirements. The impressions of our wanderings were invariably recorded within a few hours; and the entire book, with few exceptions, was written under canvas-a fact which I may urge as some excuse for shortcomings. Again, I think I may fairly claim to have omitted neither "those details wherein the difference really lies," nor the means bv which I accomplished mv iournev.

\section{ERRATA.}

Page 252, line 2, for Smečanj read Smrèanj.

" line 5, for Divja read Djiva.

" line 6, for Gacko read Gaćko.

" line 7, for Živindol read Živandol.

Uctober, 1896. 


\section{IN THE LAND OF THE BORA.}

\section{PART I._DALMATIA, 1894.}

\section{CHAPTER I.}

I can hardly say what first turned our thoughts towards the eastern shores of the Adriatic, but of this I am sure, that two years elapsed from the time that the word "Dalmatia" was first mentioned between us, until that at which our plan took a concrete form. The next allusion either of us made to the province-I beg its pardon, the kingdom-was when I discovered in a German sporting paper, Der Weidmann, that the shooting there was entirely free. This naturally strengthened my inclination towards it, even in spite of the fact that the editor of the abovenamed periodical, writing privately, said that the sport was very indifferent. Unfortunately for himself, he went on to give his reason for saying so, which was that it was free. Now, I have in the past enjoyed, and hope in the future to 
enjoy again, many good days' shooting in lands where game laws are not-not that, by the way, this is the case in Dalmatia. Moreover, he went on to speak in flowing terms of the sport attainable in Bosnia and the Herzegovina, and I could not believe that none of the bears, wolves, and other beasts, which he spoke of as existent there, ever crossed the frontier.* Another authority, also German, said there were plenty of waterfowl, and also stonehens (Steinhiitner). What these were I could not guess, unless ptarmigan (Schneehühner) were meant. This same writer said the jackal was to be found on some of the islands; but although he is doubtless a rare beast in Western Europe, I could hardly fancy myself treating my old friend the jack as food for "villanous saltpetre" after the many pleasant gallops he had provided in bygone years. I was surprised, though, to find that neither of them mentioned the boar as an inhabitant of the district, knowing what good bags of these animals the Corfu garrison, in the days when it was an English possession, used to make on the Albanian coast.

After all, sport was really a secondary consideration, as it often must be when ladies form part of an expedition.

* Ultimately, as will appear hereafter, we had to give up all hopes of the visit to the Dinaric Alps, which formed part of our original programme. 
All the authorities seemed to agree in this, that Dalmatia offered a deliglitful climate, lovely scenery, and, above all, something new. This really was the great attraction. When your neighbour at every dinner-party is equally familiar with Cairo and Calcutta, Boston and Bendigo, Reykjavik and Rio, it is really an achievement to discover a country with which the British tourist has not yet familiarized himself. That this is the case with Dalmatia, I think I can easily prove. When I first thought of going there, I wrote to ask the great-the only-Cook the fare to Spalatro. I need hardly say that he promptly furnished the required information, but he also added that he himself could not personally book us beyond Trieste. This settled it. A country to which Cook had never "personally conducted" the pavid spinster or the plethoric publican was indeed a terra incognita. To be sure, our authority went on to say that there were no hotels except in the principal towns (and he might have added that they were uncommonly indifferent even there), but this to us was only holding out an extra inducement. Had we not. slept peacefully many a night under canvas in the Far East, lulled to sweet repose by the longdrawn snore of the faithful chokedar.* Tents and camp gear presented no difficulty. Then we were 
told that to some of the islands there were no steamers, whilst to others they only ran at long and fitful intervals. Tant mieux; so much less chance of the stray tourist having demoralized the inhabitants. Islands are naturally the homes of fishermen, who must have boats; and these boats should convey us, camp and all, wheresoever we would wander.

After we had thus made up our minds that Dalmatia lay so far away from all we held familiar, it was rather a blow to me to find out, as I did, that I had a second cousin living there. But then he is a Jesuit, and the man who wants to visit countries where they are not to be found must go in a balloon. As he was there we determined to utilize him, and see if he could get us a servant equal to our modest requirements. He answered our letters most kindly, especially considering that he had never seen, nor perhaps ever heard of, us. He tried his utmost to dissuade us from our projected trip, pointing out the possible dangers to our health of camp-life in bad weather, quoting that well-known Adriatic bogey, the bora wind, which he felt sure would blow our tents to kingdom come; and finally advised us to come direct to him at Spalatro, whence he would dispatch us by steamboat to the various points of interest on the coast and in the islands.

Now, I was well aware that the bora constituted 
a real inconvenience, and even danger, on the Dalmatian coast, but not, I felt sure, one that could not be counteracted by prudence, firstly, in choosing sheltered positions for the camps, and secondly, by only moving on those days when the natives felt reasonably secure that no atmospheric disturbance was imminent-a course which the facts of our temporary home being close to the point of departure, and of our voyages being short, rendered easy of adoption.

So we returned answer, despising the seductious of Spalatro hotels and steamboats, but promising the worthy father a visit later.

Having failed to get a servant through this medium, and also from a Zara hotel-keeper to whom we wrote-and who never answered-we were rather at a loss till my wife came to the rescue with a brilliant suggestion, Why take a servant at all? So finally, after some discussion, it was settled that we should go on the American plan, and trust to luck for any assistance in work that our own hands could not enable us to complete.

Our "expedition" was thus finally made up of my wife and self, with our two dachshunds, Waldmann and Rex-" the red dog" with whom some of my readers may have already made acquaintance in the pages of "Gun, Rifle, and Hound." Excepting in so far that the little 
fellows are my inseparable companions, and proved useful watch-dogs, I must frankly admit that they were not that success in Dalmatia which they had previously been in German woods and Ardennes forests. They seemed to feel the disadvantage they were at among the rocks and mountains, and only worked really well in the vineyards and marshes. To any one who may think of following in our footsteps, I would recommend the taking of one or two pointers or setters, or preferably one of each, as the former will suffer in the feet from the sharp rocks, whilst the want of water will often knock up the latter.

* * * * * * *

Assuming that the average reader knows no more about the matter than I did before I went there, I may, perhaps, be allowed to say a little about Dalmatia. The only connection the name formerly had in my mind was that it was the native home of those quaint-looking black-and-white pointers, vulgarly known as "plum-pudding dogs," one of which, in my young days, invariably formed part of a well-turned-out London equipage, but which now seem in a fair way to become as extinct as the dodo. In this case it will certainly not be to Dalmatia that fanciers will be able to resort to renew their stock, for I never saw a single specimen of the breed there, and can only suppose that some wag named the breed on the lucus a non lucendo principle. 
These are a few facts, some of which I learnt previously to going there by studying the authorities (all foreign) on the subject, and others of which I obtained locally. Dalmatia is now, and has been since the termination of the Napoleonic wars, an Austrian province, and, by virtue of its possession, the Emperor of Austria adds to his many titles that of King of Dalmatia. It comprises the former trans-Adriatic possessions of the Venetian Republic, as well as of that of Ragusa and other lesser ones, together with a bit of Turkey handed over to Anstria in 1882 (the Spizza district). In position it extends along the east coast of the Adriatic, and is, though only a narrow strip, of the respectable length of two hundred and twenty English miles. The islands, whose area bears a very considerable proportion to that of the mainland, may be roughly divided into two groups - the Northern or Liburnian Archipelago, ending near Sebenico; and the Southern one, extending from Trau to Ragusa. Their number is enormous, but many are mere uninhabited rocks. The three largest in order of size are Lesina, Curzola, and Brazza. No better idea of the nature of the country can be given than that which can be obtained from the following statement: eleventhirteenths of the whole country is entirely sterile, being nearly all rock.

Although Dalmatia has formed an integral 
part of the Amstrian Empire for the best part of a century, it is only in the last fourteen years that it has become of any political importance. When, after the events of 1880, the Turkish provinces of Bosnia and Herzegovina were handed over to the safeguard of the Austrian Empire, it at once became obvious that the most convenient mode of access thereto was to be obtained through Dalmatia. On the principle of one good turn deserving another, it was the possession of Herzegovina which enabled Austria to finally subdue and to subject to her conscription the turbulent peasantry of the Crivoscie district, who, in 1869, had successfully opposed the Viennese authorities, being principally enabled to do so by the vicinity of the Turkish frontier. Most of them have since emigrated to Montenegro. It is through Bosnia alone that the Dalmatians. can reach their capital by rail, from Metcović, though the route is a somewhat circuitous one, and it would be more to the point if the other line were continued from Knin; but to this subject I shall return later. At any rate, the Dalmatian route is far the most convenient one an Englishman who wishes to visit the "administered provinces" can take.

The only towns of any importance in the province are Zara, its chief town, Sebenico, and. Spalatro. Of the others, none have an "official 
population" of ten thousand, except liagusa. These official figures are decidedly misleading, as they refer to the electoral communes, and lead one to expect a much bigger place than one actually sees. For instance, the Commune of Sebenico extends from Vodice to Rogosnica, say twenty-three miles. The following table will show the difference between the official numbers and the approximate population of the towns themselves :-

\begin{tabular}{lccc|c|c}
\hline \multicolumn{3}{r|}{ Name of town. } & & Official population. & Urban population. \\
\cline { 1 - 1 } Zara & $\ldots$ & $\ldots$ & $\ldots$ & 24,736 & 19,000 odd \\
Sebenico & $\ldots$ & $\ldots$ & $\ldots$ & 20,023 & 8,000 \\
Spalatro & $\ldots$ & $\ldots$ & $\ldots$ & 22,716 & 15,000 odd \\
Knin & $\ldots$ & $\ldots$ & $\ldots$ & 20,940 & 2,000 \\
Ragusa & $\ldots$ & $\ldots$ & $\ldots$ & 11,177 & 6,000 odd \\
\hline
\end{tabular}

From which it appears that the real population of Zara only in any way approaches the published figures, whilst Knin has not a tenth of the number with which a stranger would credit it. 


\section{CHAPTER II.}

Dalmatia can be conveniently reached from England by various routes. The quickest, which was also the one we adopted, is that by the Saint Gothard, Milan, and Ancona, from which last place there is a regular weekly service of steamers to Zara. This route can, of course, be varied in a number of ways, e.g. by taking the Paris and Mont Cenis line to Milan. The cheapest route is that by Harwich, Antwerp, Luxemburg, Basle, and Innsbrück to Trieste or Pola. In this case the railway journey is also about forty-eight hours, but the sea-voyages at both ends are considerably longer. In the latter case the steamers call at several ports en route, unless one takes what the Lloyd people call their "Dalmatian" line. These boats only call at one place, Pola, between Trieste and Zara. If, however, time is no object, the others will be preferred, as enabling one to see a little of Istria, which is not uninteresting. In both the above cases I assume a start to be made from Zara, which, with the exception of some islands, is the extreme northerly point of the province. 
There is, however, a third way of going out, and one to my mind infinitely preferable to either of the above, when neither time nor money is an object. This is to take the weekly Peninsular and Oriental steamers to Brindisi, and thus dispense with the tiresome railway journey, with its four or five custom-house formalities. Brindisi is in regular steamer communication with Corfu-in itself well worth a visit-and thence the steamers, touching at one or two Albanian ports, land the traveller at Cattaro, to all intents and purposes the most southerly point of Dalmatia. Another great advantage of this route is that one can take all one's camp equipment with one, whereas, if one goes by land, it must be shipped on to Ancona or Trieste a month in advance. This southern approach is especially suitable to those who go to Dalmatia early in the year, enabling them, as it does, to go north as the season gets hotter. It is almost superfluous to add that Dalmatia is not a suitable climate for camp-life before March, even in the south. As an alternative, the Indian mail route can be taken to Brindisi by those who wish to go in spring. This port is also in regular steamer communication with Ragusa, but there does not seem to be any object in beginning in the middle of the country in this way.

I have said that we selected the quickest route. Indeed, we were obliged to do so, as our start had 
been delayed two months. I had intended to leave early in June, and this I still think the best time for the purpose. But August was a week old before ever we saw Dalmatia. Passing over in silence the well-known continental transit, I will proceed at once to the last stage of our railway journey. The Ancona express leaves Milan at half-past one in the afternoon, and when we had seen the last of the familiar dining-room at Bologna, the novelty of the journey commenced for us. Unfortunately, it was dark when we reached the Adriatic at Rimini, and the only evidence of its presence that night was the murmur of the surfa sound, I think, that is always homelike to the Briton.

At Ancona we found all our camp gear except one very important item, the camp-beds, and these we were obliged to replace in a hurry by Italian brande, or folding bedsteads, of which more anon.

The steamer agent had written us that the Zara boats left Ancona at " 0.30 Wednesday," so of course we expected to leave next day, August the eighth. We had yet to learn, however, that at Ancona " 0.30 Wednesday" means Wednesday night, or really Thursday morning, so we were let in for a second day at Ancona. However, a couple of days can be spent pleasantly enough in the quiet Italian seaport. The forts, the harbour, and, if one must say it, the glare, are provocative of 
recollections of Malta. The two bathing establishments are excellently managed, and it is a capital idea to be able to follow up one's bathe by lunching at a table close to the sea. In fact, especially as the heat was very great, one would willingly have spent the whole day at one of these places, had they only provided a decent readingroom in addition. But literature is not an Italian want; nor, I may add, are comfortable loungingchairs.

The heat and drought had lasted over two months, we were told, so we were decidedly unfortunate to have to go aboard, as we did after dinner on Wednesday, in the most terrific rain. Being wet through, we thought we could do no better than turn in, which we did. I woke at the familiar sound of the siren, and, though I did not look at my watch, I fancy we sailed fairly punctually. "Now," thought I, "it is a clear rum to Dalmatia."

Between six and seven I was on deck, and found the steamer, Barion by name, going about eight knots among an archipelago of barren-looking Dalmatian scoglie. This word is applied equally to the large islands and to the little ones, and even to the mere reefs. The sea was dead calm, and the morning bright and hot, so that there was no reason to suppose that we should meet with the slightest difficulty during the remainder of our 
voyage. We sat down on deck, where most of our fellow-passengers were assembled, and waited for our coffee to be announced.

All at once we heard a shout; the engines stopped, and the rattle of a cable through its hawse-hole followed, accompanied by profuse Italian language, mostly bad. Going to the side, I saw that the ship had been steered for a channel some forty yards wide, between a long island (Melada) to port and a barren rock to starboard. Through this passage the water ran in a very broken manner, ominously suggestive of shallow water and a strong current.

Now we are going astern, and slowly, slowly the ship heads to the southward, her screw not five yards from the dry rocks on shore. Nothing but the knowledge of the precipitous nature of the coast of these islands warrants the execution of this otherwise perilous manœuvre. At last the bow swings clear, the anchor is catted and fished, we pass round the little scoglia, and, finding our proper channel on its southern side, steam cheerily through. In two hours we are at Zara.

Zara, or, to give it its Slav name, Zadar, has been said to be the least prettily situated of the Dalmatian towns. Without altogether endorsing this opinion, I will say that, if it is well founded, it proves what a high standard of picturesqueness the others maintain. We found the first view of 
the city from the sea decidedly pretty, and as one thus approaches it from the northward it reminds one a good deal of St. Malo. Certainly the Velebit range, which forms the background, and the lower hills in the middle distance are desperately barren, but, nevertheless, not altogether destitute of wild beauty.

The chief interest that the Dalmatian capital has for the stranger is that it is the beginning of the East. Bright-coloured, unfamiliar-looking costumes take the place of the "slop-shop rig," now, alas! almost universal in the more commonly visited European countries. As in all Dalmatian towns, the absence of all wheeled traffic is peculiarly noticeable.

Having commenced this book with the firm determination not to write "guide-book," I must refer the reader who wants to know "what to see in Zara," to Murray or Baedeker, or whatever redbacked authority treats of Dalmatia, if any of them do. Suffice it for me to say that the "sights" are few, but that the whole town is a sight to a Western European. I may perhaps be allowed to mention the cathedral, as the handsome campanile with which it has recently been provided is the work of a British architect.

The heat was very great that morning, and we had reason to be thankful that the oriental custom of stretching awnings across the narrow 
streets prevails in Zara, and, I may add, contrasts very oddly with the modern electric street-lamps.

Zara has seen some hard lnocks given and received in its day, especially during the wars between Huns and Venetians for the mastery of Dalmatia. Dandolo took it by storm in the fourteenth century, and destroyed about half of it. It finally became Venetian territory in 1409. Then the Turk appeared, and repeatedly besieged it, but unsuccessfully, though it very nearly fell twice, firstly in 1500, and again in 1570. In the next century its troubles were varied by pestilence, the plague twice committing fearful ravages amongst the population. Its sieges ended with the Napoleonic wars, when it endured two close blockades (1809 and 1813) at the hands of its present owners, the Austrians. As its fortifications are now dismantled, it may look forward to more peaceful days in future.

As I have just referred to the Venetian rule, I may take this opportunity of saying that the Slav population attribute the fearful devastation of the Dalmatian forests indirectly to the great Republic. The fact seems to be that their officials had a nasty way of going about the country and marking fine timber trees with the lion of St. Mark. This meant that the country people had to fell and shape the trees, and, worse still, transport them to the seashore to be used for galley-building. 
The not unnatural result was that the Slavs took to destroying every young growing tree they saw - a course of action their descendants are bitterly rueing to-day. 'This is the legend; but I, who had plenty of opportunity of seeing the country, am of opinion that it by no means accounts for the barrenness of the land. The Venetians are long since gone, but the young growing trees are cut down all the same for the more prosaic purpose of firewood, or, worse still, destroyed by the animals pastured on the hills. I am convinced that if the Government resorted to the Indian plan of making "forest reserves," walled in (and the material for this is not wanting), of some millions of acres, and excluding every one not provided with a pass, Dalmatia would bear a very different aspect in a quarter of a century.

My first act at Zara was to visit the Government Offices, to which I had sent on my passport three weeks before to have my shooting-licence prepared. The responsible officer had not arrived, so the rest of the morning was spent in making our final purchases, and admiring the quaint costurnes of the Morlak peasantry.

I returned to the Municipality at noon, and was then sent to the Municipal Offices, but finally received my permit about one. We were treated with the greatest civility by all, and finally the chief of the police gave me an "open order" to 
all the gendarmerie in Dalmatia to do all they could to facilitate our wishes - a piece of kindness as unexpected as it was welcome and useful.

Our next step was of course lunch, and when we had discussed it we proceeded to the harbour, where our various properties were already loaded in the fishing-boat which we had chartered to convey us to our first camp. 


\section{CHAPTER III.}

Unfortunately, the splendid fair wind of the morning had been dropping all this time, and consequently, though we sailed at two o'clock, we had a very hot and tedious voyage, and were still some miles from Pasman village at six.

Just then we opened a little bay, sheltered by a high scoglia, and, as it seemed to me probably adapted for camping, I had the helm put up, and in a few minutes we ran alongside of a rude pier. The immediate neighbourhood of this did not offer any very great camping inducements, so I walked up some hundred and fifty yards to the right, where I fancied I saw a suitable spot near a dilapidated stone bridge.

Immediately beyond the bridge was a beautifully smooth stretch of green turf, up the left-hand side of which ran a creek of muddy water, spanned by the little bridge above mentioned. From the creek the ground sloped upwards to a low wall, which separated the grass from the cultivated land adjoining, while a few grey-green olive trees formed an effective background. I knew that, as 
there was a house near the little pier, there must be water at least as near as that, so selected this as our camping-ground, although it was rather more exposed, both to the sun and wind, than I could have wished. But there was no choicenor, indeed, any time to spare.

One of the Zara harbour porters whom we had brought with us showed considerable smartness in learning the somewhat complicated mechanism of the thirteen-foot balloon tent which Piggotts had sent out, but it was late before we bade them farewell on their return to the town. It was still later before our little leg of Dalmatian mutton appeared on the table; and I think we must have been the latest inhabitants of Pasman Island to turn in that night.

We ascertained next day that there was a well of excellent water not sixty yards inland. Pasman is the best provided with water of all the Dalmatian islands; there are many wells, and the water in all is sweet, whereas on the other scoglia it is generally brackish at best.

The site we had selected proved to be a highroad, and not only that, but the best bit of road in the whole island. However, as there is no wheel traffic on any of the islands we visited, our occupying four-fifths of the thoroughfare did not much matter, for nothing ever passed except cattle or an occasional stalwart Morlak on a very 


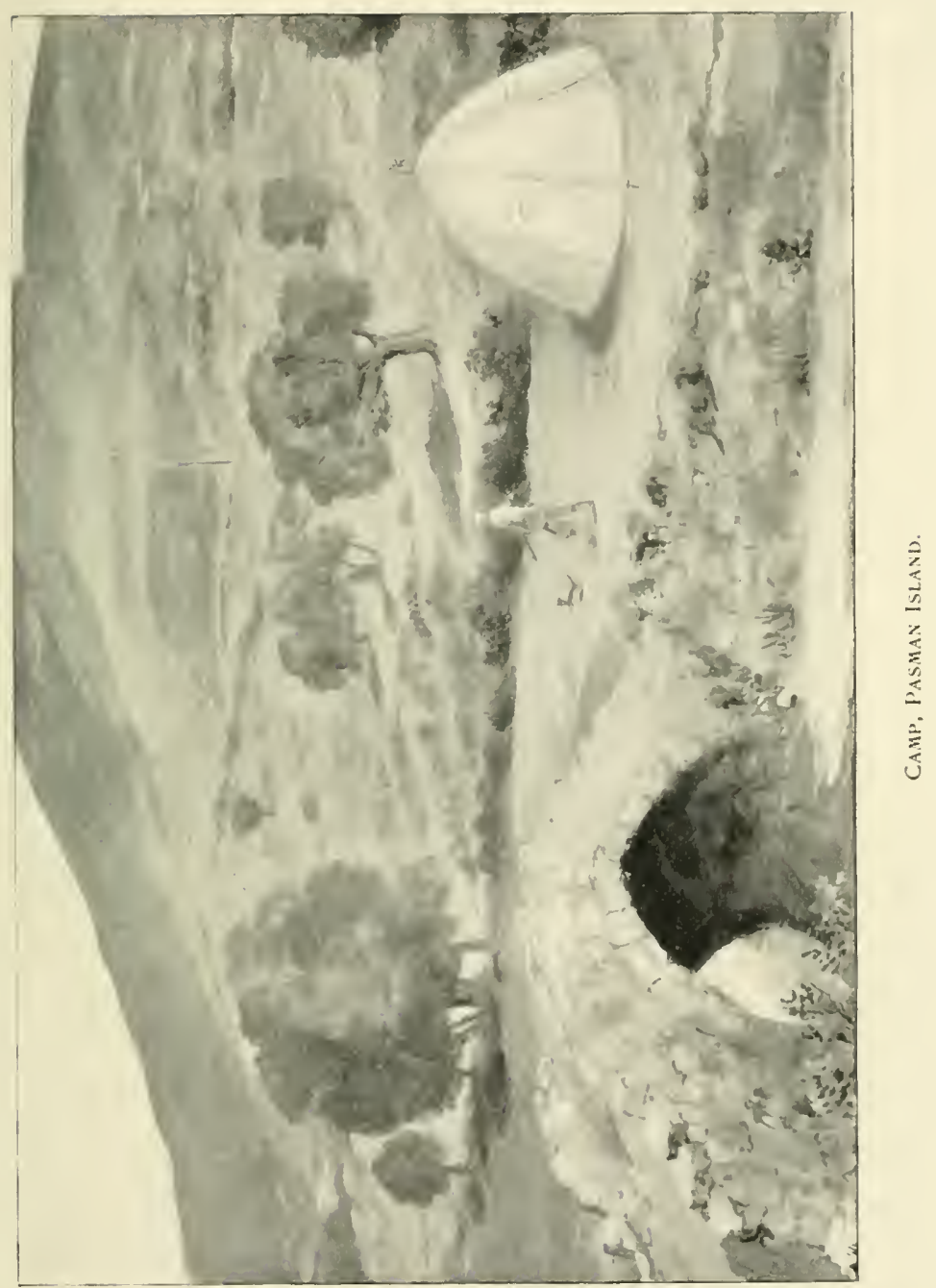



small donkey. Pasman does not even boast the wretched breed of ponies some of the islands possess. It was, perhaps, rather a drawback that numerous herds and flocks passed every morning at daylight on their way to their pasture on the hills, only to return at sumset; but we soon got used to the vociferations of their guardians, mostly women. Indeed, the women do about nine-tenths of the work at Pasman, the men's share being the ploughing with a breed of toy bullocks, and the fishing in winter. For the rest, they principally loaf and drink. At both these employments they are hard to beat.

To return, however, to our first night in camp. As I was putting up the brande, our Italian substitute for camp-beds, I heard an ominous crack; and sure enough, when I had got the thing fixed and sat upon it to try it, down it went. I slept on the ground that night-not the first time in my life by any means-but found Mother Earth's lap just as hard as ever.

I may here add that next night I rigged up a makeshift with a box and two chairs, but as it was decidedly short, E- kindly volunteered to occupy it and make over the remaining branda to me. Result-at about eleven o'clock, when we were all wrapped in profound slumber, crash! I went down on the unfortunate dogs sleeping below; and that night too the ground was my 
resting-place. We found those beds most usefulas firewood, but for sleeping purposes we fell back on the old dodge of calico bed-bags, filled at first with straw, but afterwards, thanks to the recommendation of some inhabitant, with Indian corn leaves, which are more comfortable, and are generally used in Dalmatia. These bags Emanufactured out of some spare sheets.

Sleeping on the ground is the very best prescription I know for early rising, and I was up soon after five, and, after some tea, went out for a stroll with my gun and dogs, but saw nothing. The only covert in the low ground was formed by the dwarf vines, which reminded me immensely, in their height and colouring, of coffee-plants. The Indian corn was all dried up, and the grain of course harvested. Much of the land was fallow, covered with large and very prickly thistles. It was very hot when I returned, and I was glad to take a header off our little pier into the sea.

When I came back-and, indeed, before I went to bathe-I became aware of a friendly crowd of Morlaks watching our every movement with the greatest interest. The excitement rose to feverheat when I proceeded to dig out a Broad Arrow kitchen strictly in accordance with the "Regulations for Encampments." This interest continued till we left, but the curiosity, which was, to say the least of it, embarrassing, decreased with the 
novelty of the thing; but I shall, I think, never forget how I roared with laughter at the sight of $\mathrm{E}$ - cooking our first Sunday dinner under the admiring gaze of about seventy-five men, women, and children.

For the rest, we found the islanders kindly, honest, and simple. Their dress is peculiar, running as it does to waistcoat at the expense of the coat. The waistcoat is the garment; it is made of brightly coloured cloth, and often handsomely braided. Besides the ordinary or useful buttons, it always, unless the owner happens to be financially in a bad way, boasts a double row of large silver ones on long stems, which are frequently made of old coins. The women wear no stockings, but leggings of blue cloth, wrapped round and round, descend to the ankle, somewhat after the fashion of Indian putties. They cover the head only with a kerchief, but the men wear a red flat cap of fez-cloth. My wife tells me the women's dress in Dalmatia is rarely tasteful, though neater in Pasman than in most parts of the province, except in the mountains. In Spalatro one sometimes sees curious and handsome costumes. The Pasman women wear a blue bodice and skirt. The former is cut square in front to show the white chemise, whose full sleeves show below the short ones of the upper garment. The opening in front, the girdle, and the hem of the 
skirt are often handsomely embroidered; but the latter garment is of ugly cut, and, being short in front, accentuates the shapelessness of the gaiters and the huge raw-hide sandals.

Saturday, August 11, was another grilling hot day. I was up at half-past five, and, as soon as tea was dispatched, I started off along the coast with dogs and gun. I passed the ruined church of San Michele, and then, getting rather tired of seeing nothing, I turned towards the hill. The dogs were very beat for want of water, and would hardly work. I found the hill road rather rough, but nothing to the hill itself, which resembled a staircase struck by lightning more than anything else. The only vegetation was a few scattered bushes, rhododendron-like for the most part. At last I reached the summit of Mount Bokolj (900 feet), having seen no signs of game all the morning. Truth to tell, I had not expected much more. The shooting in the Dalmatian islands is good, but only at certain fixed periods. It is only birds of passage that make it worth having. Twice a year the quail pass, and in October and April scores of woodcock can be bagged in a day. On the mainland there is excellent winter shooting, but only in those places which, from the nature of the country, are suited to water-fowl. Stonehens, of which more anon, are not common in the scoglie. By the way, I found the jackal story 
corroborated at Pasman. The stock there had become reduced to some seven or eight, and some years ago the peasantry combined to destroy them all. Why, I know not, unless perhaps they were destructive to the grapes.

The view from Mount Bokolj is grand. To landward the coast-line from Zara to Zaravecchia is backed by the arid Velebit range; and a few miles south of the latter I could distinctly see the great Vrana Lake. To the westward lay other islands: Lunga and then Incoronata-this last almost uncultivated, and only inhabited at times. On every side were dozens of small scoglie.

I fixed my bearings towards camp and started down the hill. Unfortunately, before I had gone far I got among a network of hill-vineyards, which formed a most exasperating obstacle. These vineyards are made as follows: A piece of the hill being selected, the owner proceeds to carry all the stones thereon to the sides, where he places them so as to form wide dikes from four to eight feet high. Some idea of the nature of the ground on these islets can be formed by the reader when I say that these are often insufficient, and it then becomes necessary to pile them up in huge square cairus in order to clear the ground. It may be readily imagined that a score or two of such dikes form no mean impediment to rapid progress, especially when one has a couple of dogs 
to lift over each. Moreover, the dwarf vines with their long trailing branches are by no means easy to progress through, having due consideration to the grapes, now nearly ripe.

At last I reached a brae overlooking the valley, and struck a rough path, or rather watercourse, through high bushes. I followed this for some way, when, to my disgust, it ended in a (dry) waterfall with precipitous rocks. Retracing my footsteps very unwillingly, I struck another track, which finally brought me down among the olive trees. When we reached the sea the dogs rushed madly in, so distressed were they.

Five minutes later they had their drink, and I mine. It was just eleven o'clock, and I felt a bit beat, but a header in the sea put me right.

After lunch I happened to peep out of the tent, and noticed a wisp of sandpipers calling and running on the beach just outside. I got my gun, and, waiting till several of them got together, I "browned" them, and bagged two; so that our first Dalmatian "game" was literally shot out of the tent window. At dinner that day they were pronounced so excellent that the only regret was there were not twice as many.

That afternoon we had our first rain-a heavy thunderstorm lasting nearly two hours, which was followed by another the next morning from seven to eleven, but the tent stood it well. 


\section{CHAPTER IV.}

Mondar was the 13th of August, and I went out for a while with gun and dog-not without thinking of the grouse-shooters at home, but, unlike them, I saw nothing. The heat was very great, but we found the balloon tent, with its lower edges turned up a couple of feet, was always cool and pleasant, except on the rare occasions when there was no breeze.

The next day we had our first experience of the dreaded bora wind, which blew hard from noon till sunset. In spite of our exposed situation, it did us no harm, and, with proper attention, it is very difficult for the wind to do any to Captain HoustonStewart's patent tents, as, besides being bolted down in the centre, they expose so little surface to the wind.

A word as to the topography of our first island. Pasman runs, roughly speaking, truly from northwest to south-east, and is twelve and a half miles long by one and a half wide at its widest part, near Pasman village. It is only separated from the next island to the north, Uglian, by a tiny strait, and the two islands together form the western 
boundary of the southern part of the so-called Canale di Zara, which extends north many miles beyond the town from which it takes its name. These canale, of which there are several on the Dalmatian coast, afford considerable protection to coasting craft, in the same way as does the "Inner Lead" on the Norwegian coast. The work of building lighthouses is still being carried on, and if these sheltered waters were thoroughly lighted, they would, of course, be available for large ships too, as there is plenty of water.

Pasman presents no features of archæological interest, except, perhaps, its two monasteries of San Benedetto and Tkon. The former, which is situate on a hilltop, is now disused. It has no water; but monks, if tradition is to be believed, never were much given to the use of this, either inwardly or outwardly. The latter is a foundation of King Crescimir III. of Croatia. We paid the good monks a visit, and were most hospitably received. The church contains some very old pictures, and the old buildings, surrounded by a lovely garden, afford a delightful picture of peaceful repose. Close to it would be an ideal spot for a camp. The monks make excellent wine, and were good enough to let us have a supply for our own use.

A few days later, having been assured that there were both hares and "birds as big as fowls" on a 
certain hill, I gave the place one more thorough trial. I left camp about 3.45 a.m., and stumbled up the roads (?) leading up the hill to our westward, by the light of a waning moon. In twenty minutes I had reached the "staircase struck by lightning," and followed a steep track up to a saddle between two peaks. The ground here became a mass of loose stones of varying sizes, but mostly about half as large as one's hand; no vegetation grew among them. This led me to a punch-bowl-shaped hollow, some quarter-mile across, which I, although possessing no pretensions to geological knowledge, was at once able to put down as the crater of a long-extinct volcano. Only three peaks remained to show the original height of its edges. In the centre I could see some stone dikes-a sure sign of cultivation; but as there was not light enough to shoot, I sat down for a quarter of an hour. I had good hopes of sport, as the dogs were already feathering busily about.

At daylight I advanced, and found a small group of vineyards before me. The dogs at once commenced keenly to try them, but I was not fated to have any sport on Pasman. What the scent was they kept on picking up here and there, and also every fifty yards throughout my walk, I could not then imagine. Now, judging by the light of later experience, I feel sure that it was where stone-hens had been feeding about, and had I then known that 
I ought rather to have tried the rocky ridges and peaks, and not the flat, I should very likely have had some sport. Unfortunately, I did not.

From the punch-bowl I took a beat up a long stretch of moor-all rocks, of course-and finally struck a long narrow glen running due south. The dry watercourse running down it accounted for the luxuriant nature of the bushes here-as before, mostly rhododendron-like shrubs mixed with juniper and enormously high heather. I could not help thinking what a lovely beat this would be in October, when there are plenty of woodcock about. The glen went on deepening, with masses of rocks on each side, and finally brought me out a mile behind Pasman village. This is a mere hamlet, with houses enough for four times its population. But disused houses are to be found all over the island. It appears that in the seventeenth century the plague reduced the population to three individuals, and, though the island is now repopulated, the superstitious natives invariably refuse to utilize any of the old houses, which they allege to be haunted. From this point a hot walkfor the sun was already very strong-brought me back to camp at eight, quite ready for bathe and breakfast.

As I am on the subject of the superstitious nature of the Dalmatian peasant I may quote a German writer on the subject. He says, "They 
are convinced of the existence of witches and of those possessed with devils, of the danger to be dreaded from vampires, of the existence of ghosts. They protect their cattle with amulets against disease, and themselves with talismans against epidemics." He might, however, have gone much further, and said that they are all afraid to go out alone at night. . Besides, what is the violent ringing of church and chapel bells which goes on throughout every thunderstorm but a relic of a belief in maleficent demons in the elements, which the holy bells will drive away? The priests laugh at their practice; but when I asked an educated individual, "Why, then, do they allow it?" the answer was, "Because they would very likely be killed if they did not."

I can pass over the remainder of our stay at Pasman as of no general interest. Boating, bathing, and profitless rambles with the gun, resulting only in a few hares and quail in half a dozen days, filled up our time, not forgetting the inevitable hard work an independent camp involves. One of the islanders, by name Carlo, and by nature the champion loafer of the island, had attached himself to us at our arrival; but, finding we required so very little attention, he finally limited himself to little more than bringing milk for sale every morning. He had the audacity to appraise these services at one florin and twenty 
krentzers a day, but when I offered him two florins on condition he should come with us and help pitch our next camp, he cheerfully accepted.

A great resource to us both, and especially to my wife, during our stay at Pasman was the society of the family of the chief financial official of Dalmatia, whose acquaintanceship we formed soon after our arrival, and whose kindness I am glad to be able here to acknowledge. They were doing very much the same thing that we were (only their house was of stone instead of canvas), to the huge delight of a large family of young people. When we spoke of departure, they very kindly gave us a letter to the priest of Pakostane, a hamlet some dozen miles further on, and a spot where we hoped at once to avoid fever and yet to see something of the mainland.

Anxious to avoid the inevitable crowd Sunday in a fresh camp would bring, we prolonged our stay in Pasman over the next week-end, and arranged to leave on the 20th of August. As I have said, we had arranged for Carlo to accompany us. We hired the boat of the owner of the cottage by the pier, whose name I forget now, but whom we styled the Syndic, principally on account of the dignified manner he used to ride about (he was a fine, portly man) on a very small donkey. At loafing he ran Carlo a good second, but he did occasionally do a little sponge-fishing. We bought 
some of his catching for about a fifth the price we should have had to pay in England.

On the morning of the day fixed, we struck camp at eight and sailed at ten. For over an hour we drifted, the wind being light; but then a nice breeze sprung up and carried us in little over another hour to Pakoštane. Here our first step was to call on the priest. Unfortunately, the reverend gentleman was away when we arrived, but we were hospitably received by his brother, who proceeded to show us the ground available for camp. My heart sank when I saw it-a succession of cultivated fields. However, there then seemed to be no choice, so I picked out that which seemed to have been longest fallow; the boat was brought as near to it as possible, the things were landed, and the tent pitched.

Towards evening the priest returned, and at once came to see if we had all we wanted. In the mean time I had seen the local gendarmes. There are none, as a rule, at Pakoštane, but there had been a free fight in the village the previous week, which had brought down on them a temporary detachment of two men. They at once came round to our camp, and ordered the populace to keep away from the tent-an order which was promptly obeyed, much to our relief. This, however, was not all; for at night, when we were about to turn in, I heard voices, and, 
looking out, saw two peasants approaching. They proceeded to spread out rough rugs on the ploughed land, and, wrapping themselves in others, lay down. I then went to try and ascertain the cause of this, when one, who could speak a little Italian, informed me that they had come as a guard to us by order of the gendarmerie. They refused to accept my suggestion that they should go home, and that I should say nothing about their having done so, so I bade them good night. The night was fine, and after all a Morlak peasant's house is not much more comfortable than a ploughed field, barring the roof, which, however, is not always watertight.

The priest and the gendarme are all-powerful in Dalmatia, and as they do not, as in some countries nearer home, pull in different directions, this was only a trifling example of their power; for it appears it was the priest who had suggested these sentries to the policemen. Next day I protested against it as quite unnecessary, and it was not repeated. 


\section{CHAPTER V.}

Pakoštane is utterly unprovided with the necessaries of life. Even water is not to be had, and we were beholden to the priest for a supply from his tank of rain-water. Not being able to get any supplies locally, I had to go to Zaravecchia the morning after our arrival, to lay in storesbread, meat, and other necessaries. Fortunately for me, the priest was driving to San Filippo, which lies beyond, so I got a lift there. As, however, he was to be away all day, I had to walk back, and six miles in that heat-it was past noon when I returned-I found quite enough, especially with a heavy load in my ricksack. Zaravecchia, though a place of great antiquity-it is the Biograd of the Croatian kings, and was destroyed by the Venetians in the year 1127-is entirely without interest, and is nowadays only a large village with some coasting trade.

In the afternoon the priest sent us his boat, and after a bathe off it I felt fit enough. We then sailed to a neighbouring rocky islet, where there were some rabbits, which, however, did not 
condescend to give us a shot, though the dogs found and hunted several.

Next day was to be devoted to an excursion to Vrana. The priest had kindly introduced us to a local landed proprietor, Peličarić by name. $\mathrm{He}$ promised to drive us out there at daylight.

Vrana is some five miles from Pakoštane. The road to it passes round the northern end of the largest Dalmatian lake-also called Vrana-and runs along a beautifully shaded causeway between the water and the marshes. These latter extend many miles to the northward, and account for the fever which plays such havoc with the population. The lake itself is about nine miles long, and the whole district provides the best shooting in Northern Dalmatia. Even at this time it was literally covered with duck, but in winter there are immense quantities of woodcock and snipe, besides other migrants rare to us in England, such as wild geese and swans. I was also told wild boar come down every winter, but I have some doubts as to the accuracy of this statement.

Seen across the lake Vrana appears a place of some size, but when approached nearer turns out to be principally ruins-a few scattered huts containing a population of some three hundred souls, all lantern-jawed and yellow with fever. The principal ruin is that of a large castle, built by the Templars, but soon afterwards taken by the 
Turks. It was in such a state of decay that I wondered how any one could identify the various portions Peličaric pointed out, such as the chapel. I myself should be sorry to swear to anything more than the well, now dry. Our host's house is an old Turkish bey's palace, also extensive, but mostly in ruins. In it also stands a shooting-box of the Counts of Vrana.

The story of Vrana is simple. Originally a flourishing Venetian colony-indeed, it is said to have had as many as thirty thousand inhabitants -it fell into 'Turkish hands. These latter neglected-as they always do everything-the canals which then drained the marshes, and they fell into disrepair; then came the fever, and for centuries the place has been what it is now. It is said that the Austrian Government intends to redrain the marshes shortly-an immense reform, however prejudicial to the sportsman. It would present no great difficulties, there being a fall of something like forty feet from the upper end of the marshes to the lake.

We left $\mathrm{E}$ - to rest a while, and went out into Peličariç's vineyards to look for quail. $\mathrm{He}$ bagged some half-dozen, and I missed about as many, greatly to my surprise. No explanation was forthcoming till next day, when I opened some of my cartridges, and found that, instead of being, as I supposed, small shot, they were number 
four's-useless of course for quail, especially in a small-bore gun such as I was using. The dogs worked capitally, the red dog twice retrieving wounded birds.

After a couple of hours of this sport we returned, and walked with E- to see the old castle, and thence on to the celebrated Grotto of Vrana. From a wall of rock a stream of water flows, but it is possible to pass behind the wall and enter a sort of cavern, or rather cleft in the rock, for it is open to the sky. In this there are two streams of water. By wading waist-deep up the first, a series of caverns, all full of water, can be entered. The cleft itself is a pretty spot, the rocks being covered with maidenhair fern and other damp-loving plants. Unfortunately, they are also disfigured by hundreds of names being scrawled upon them, among which I was surprised to see several times that of the noble family who own the place, and who might have been expected to know better.

From the grotto we returned to Peličarićs house to lunch. In the afternoon we shot again, and returned to Pakoštane in the cool of the evening.

We had decided that our present camp was too dirty to be endured, for everybody-including the dogs-who came into the tent brought in a plentiful supply of earth, and the possibility of 
rain was awful to contemplate. Accordingly on August 23 we moved to a green scoglia, or, as we should say, holm, a couple of hundred yards out to sea. This is called the Island of St. Justina, and on the land side still exists her tiny chapel. At the time of our stay it had been recently re-roofed, but not yet re-consecrated. This islet served as a refuge to the inhabitants of Pakoštane when the Turks came down; and one can readily imagine the Slavs cursing in impotent wrath as they watched the smoke going up from burning houses and crops, the Moslems, for their part, riding along the beach and shaking their long spears in idle threat. A few ruined walls still mark what no doubt have been buildings of refuge, but probably no one had slept on the islet for centuries.

The islet is of course waterless, but this is a remark that applies to almost all Dalmatian camps. It is about a hundred and fifty yards in length, and little more than half that width. Where not rocky it is covered with coarse grass, and we soon found a clear and green spot, somewhat to seaward of the centre, on which to camp. Whilst we were pitching our tent, I heard squeals, and, going to the spot, found Rex with a full-grown hare, which he had caught in its form. Some days after, some men came to look after "five hares which the schoolmaster had turned down there." 
I told them I presumed four had died a natural death, but that I knew one had died a violent one, and very poor eating he was. When camp was pitched, a small water-barrel was placed in the chapel, and our Crusoe-like existence commenced. It had many advantages, first and foremost being the privacy. Then the bathing was much better, the water near our last camp having been both shallow and rocky. There were still, however, more sea-urchins than might have been wished. The sea-water, as it is everywhere in Dalmatia, was clear and delicious, and as it is particularly rich in iodine, the bathing is most beneficial.

The first day, as usual, was consumed in little else than arranging our new camp; but on the following one I went off to the mainland by the milk-boat, and walked over to the lake. I did not, however, succeed in getting a shot; and it was rather tantalizing, after wading up to my thighs for half an hour in the vain hope of getting a chance from behind some clumps of reeds at a duck, to be met by a Morlak with five nice widgeon for sale, shot, he said, on the marshes, and no doubt by flighting on the marshes at daybreak or at dusk-a process for which I had not time, and, moreover, one not unlikely, in summer, to result in an attack of fever. Now, I am like the Frenchman, who, when asked to go out hunting, replied, "I've been." I have had fever and ague, of 
which it took me a good five years to get rid, and I don't want to try it again.

The next evening, however, I walked down to the marshes-nearly an hour's walk-getting there at about five o'clock. I had not gone through much of them before, to my delight, a snipe got up, and, although they were rather wild, I managed to get a nice little bag of longbills before dusk. I then sat down for a bit, but though I saw plenty of duck, I soon found out I was not in the right spot to get a shot, as they all passed too high up and too far to the eastward.

As I was stumbling home in the dark, a waggon full of Morlaks overtook me, and one of them who spoke a little Italian offered me a lift, which I was not sorry to accept, but I think I never had such a rough drive. The roads in this district are made by the simple process of removing all the larger loose stones and piling them into dikes. The smaller loose, and larger fixed, stones remain and form the roadway. I had already been fairly well bumped in Peličarić's "shay," but that was quite a joke to this, for the ponies rattled along at a good pace, and springs there were none. I can conceive no finer exercise for the liver. The very flesh on my cheeks shook; and had not our Jehu come slowly off the top of the hill into Pakoštane village, I feel convinced we should all have been shot out by the mere bumping. 
The following evening I returned to the marshes, but met with the worst of bad luck, for the first cartridge with which I dropped a bird jammed hopelessly, and I had to turn homewards. I was well out towards the middle of the fen, and as I was floundering back a skein of widgeon swept over me. Although they were rather high up, I gave them the left barrel, and the one I had picked out, after staggering about a bit, fell a long way on. Of course I turned back to get him, but to my regret the bog got so deep that that and the rapidly setting sun warned me to give it up, and I turned regretfully away, only reaching terra firma just before dark. As I have before said, these marshes are many miles in length, and here, near the lake, they must be a couple of miles wide. I cannot conceive any more fascinating spot for winter shooting, or, rather I could not then, but perhaps the Narenta marshes in South Dalmatia should be awarded the palm.

This was the last day of our Crusoe-dom, and much we regretted to leave our pleasant islet. The priest, who is an enthusiastic sea-fisherman, had placed his boat at our disposal for our move, which we fixed for the 28th of August. 


\section{CHAPTER VI.}

IN the morning we bade farewell to our host, as I may call the priest, Dom Nicolo Milić, Saint Justina's Isle belonging to the Church. He furnished us with a letter to the one at Morter Island, whither we were bound. We struck our tent about one, and, sailing about two, reached Morter village before four, having hugged the shore nearly all the way. The voyage was perhaps the most uninteresting which we made in Dalmatia; but the combination of a fine day, a fair wind, and a fast sailing-boat made a pleasure of it.

The priest here, Dom Niko Plančić, also a young man, was quite as willing as the last to assist us, but totally at a loss where to suggest " a pitch." I had, however, kept my eyes open coming into Morter bay, and had noticed a possible place about half a mile north-east of the village, and adjoining the local cemetery. To this spot we proceeded, and found what we decided would do, though it was rather stony. It was on the point which forms the eastern limit of the bay. 
We had always been near the sea hitherto, but this time we were almost in it, deepish water coming up to a rough sea-wall three yards from the tent door. A few feet to the right it was deep enough for a header.

The unaccustomed sight of the canvas dwelling and the Union Jack fluttering in the breeze of course brought a few natives to stare; but the islanders here are more hardworking and perhaps more civil than most of the Morlaks, and next morning we were little troubled.

In the evening the priest conducted us to the little chapel of San Rocco, which overhangs the village. It is a stiffish pull up there on a hot day, but the effort is more than repaid by the glorious view which is obtainable in every direction, but especially to the northward. Incoronata, which really seems impossible to get away from in North Dalmatia, closes in the horizon for miles to the west and north-west. As this point forms pretty well the centre of the Liburnian Archipelago, it would be impossible to enumerate half the isles, islets, and rocks we looked down upon. On the mainland we could see the lower end of the great lake with the Black Mountain behind it, and further down the first outlying spurs of the Dinaric Alps cut the skyline.

Morter Island is rather over seven miles long, and in places a mile wide. It is decidedly more 
cultivated than Pasman, every bit of the available ground being terraced out and planted. Behind the cemetery is a hill, which the priest told us had been till lately communal pasture. Permission being given to cultivate it, the whole of it was covered with hill vineyards, laid out as I have already described, in two months. When we reached the place, fig picking and drying was in full swing, and grapes and figs were to be had for the taking-by us, I mean, for though this is an act of hospitality the Morlak generally extends to the stranger, he is sharp enough on his neighbour, and if he finds him on his land, it soon becomes a matter of litigation. This is natural enough, for the stranger can but eat a pound or two of fruit, whereas the native picks for the vat. Morter is also more densely populated than Pasman, the villages of Morter and Bettina, about a mile apart, having nearly three thousand inhabitants between them. It speaks volumes for their good conduct that there should not be a gendarme nearer than Stretto, at the other end of the island, and near the drawbridge that connects it with the mainland. It has not always been so, I was told at Sebenico, where, indeed, they go so far as to style them "Morter Brigands." We only met one, and this was the first man we engaged to fetch water and do the rough work. For these services he only demanded 1fr. 20k. a 
day, or, in other words, nearly three times a day's wage; so we promptly paid him off, and the priest procured us an efficient substitute.

The inhabitants of Morter cultivate a small part of the long island of Incoronata before referred to, and utilize the rest of it as pasturage, keeping over five thousand sheep there. This is the outermost island of any importance of the Archipelago, and has no fixed population, the Morter people going out for such sojourn as their work necessitates.

The only difference between the inhabitants of these various islands as regards costume is in the men's caps. For instance, at Pasman they were all red, with a decided point in the centre; at Pakoštane the red was half covered with black embroidery; whereas here at Morter the dandies only wear a perfectly flat piece of scarlet cloth, smaller even than a German student's cap-say three inches in diameter-and secured by an elastic at the back of the head. A more useless headdress for the sun it would be hard to conceive, but I noticed that at sea they sometimes condescended to big straw hats.

Morter is slowly but surely sinking beneath the Adriatic. Near our camp there were walls to be seen below the sea in calm weather, and the very name of the spot, Gradina (the ancient dwelling-place), bears out the fact. Near Morter village are still visible Roman graves two fathoms 
under water. Assuming them to have been constructed near the sea-level of those days, this would give at least a score of feet of subsidence; and putting them back to the first years of our era, this would give a foot a century - a very respectable rate, but probably an under-estimate nevertheless.

We found the heat here very great, as, indeed, it had been for the two previous days (August 27 and 28), and, strange to say, there was very little wind. In England we are accustomed to remark upon the circumstance of its being a windy day; but in Dalmatia we ask, "What wind is it to-day?" and the answer is nearly always bora, scirocco, or mistral, as the case may be. However, at noon on the 29th, the wind got up, and we had nothing more to complain of in the way of want thereof, for at midnight the bora became most furious, so much so as to wake us up. But, although after this sleep was but fitful, the tent stood well till daylight, when I went round and overhauled all the tent-pegs. I found several of them much in need of attention, but no harm was done. The gale raged hard that day, and the next night it was worse than ever. A better test of the stability of the tent could not be desired. Friday saw little or no cessation of the wind, and we both began to get decidedly sick of this state of things.

Nor was this all. E- complained sadly of 
the difficulty of getting supplies; nor do I suppose there is anywhere in Europe a place of equal population where supplies are as difficult to obtain as they are at Morter. Even the wine-it was a week before the vintage-was out, and had it not been for the kindness of our excellent cleric we should have been unable to get any fit to drink. With the greatest difficulty we got a quarter of a pint of milk a day from Bettina. Of twelve eggs brought us six were bad, and unheard-of exertions were necessary to procure a small chicken at famine price-elevenpence. The usual Dalmatian price is sixpence to eightpence for a fair-sized one.

The whole of Morter, except some acres of barren rock to the southward, being cultivated like a garden, it goes without saying that there is little or no game on it. There are some few partridges and hares, but altogether it may be said to afford no sport, so there was really no reason for prolonging our stay. So we settled to leave on Saturday, after only four nights in this camp.

Of course the wind, which, however strong, would have been fair, dropped as soon as ever this decision was arrived at and all arrangements finally made. As the result of this, our journey (seventeen miles, the longest boat voyage we made in Dalmatia), took us over five hours. The priest and his coadjutor were good enough to say they would come with us as far as Stretto, the chief 
town of the island, and wo all embarked about ten.

Having rounded the point, we sailed past the picturesque village of Bettina. (N.B.-This place is much best seen from a distance.) Morter Island presents no features of interest, being, as I have said, almost entirely covered with vines and olivetrees. At Stretto the channel narrows to a few yards, and is spanned by a bridge, one part of which can be open by manual labour. Through this we passed, and then landed to disembark our fellow-travellers and to enable $\mathrm{E}$ - - to make some necessary purchases.

Stretto is a little place of some pretensions, going eveu so far as to boast a club, which we were shown with pride. Herewe ascertained that there was a steamer back about three from Previčio, a scoglia some miles on, and Don Plančić and his curate consented to accompany us thus far and pay a visit to some friends at the convent there, thus killing two birds with one stone. We gavo them a scratch lunch on board, and a very cheery little party we were that lovely summer day. From Stretto our boatmen continued to hug the mainland shore. To seaward, as usual, were heaps of islets, the most important being Kapri and Zuri. We passed within a biscuit-throw of the village of Tre Bocconi. Its situation on an islet connected by a stone bridge with the mainland is picturesque, 
but on nearer approach it proves a squalid little place. A chapel is placed on top of an adjoining hill, and is surrounded by a little cemetery. Quoth our priest, "We Dalmatians are born among the stones, live among them, and when we die we are buried in the rock." All the cemeteries in Dalmatia contain nothing but what we should call vaults, built of, or even excavated in, the rock. There was, however, a small annexe to the Morter cemetery, with earth graves for use in case of infectious disease.

From Tre Bocconi it was a short run to Previčio, and here we said good-bye with real regret to Don Nico, who, after such short acquaintanceship, had by his kindness really made himself a friend.

A brisker wind now got up, and soon took us past Fort Nicolò, an old stone structure guarding the ship channel, called that of San Antonio, which leads into Sebenico harbour. 


\section{CHAPTER VII.}

Alu this time I have not said a word as to our destination. Our original intention had been to go to Zlarin Island, exactly opposite Sebenico. We were, however, strongly advised from every point of view to select a spot on the mainland, and that most recommended was Zablace, some two miles beyond Fort Nicolò. We reached the pier of the hamlet in due course, and then began a weary search for a camping-ground, the place being all either vineyards or rocks. At last, nearly a mile more to the southward, we found an abandoned vineyard, and in it a spot nearly free from rocks, which I judged to be large enough for our tent. It proved to be so with not six inches to spare. Then came another search, this time for a place where the boat could approach near enough to land the gear. This we found a good hundred yards on-a longish way to have the things carried. At last it was done, but it was half-past five when all was finished.

We had not been encamped half an hour, when a local landed proprietor appeared upon the scene, 
and insisted upon our moving the tent to the vicinity of his house. We had the greatest difficulty in refusing his hospitable offers; in fact, he went so far as to come for us with a boat the next morning, but we were firm in our resolution not to move again.

As we had been at Pakoštane, so again at Zablace, we were struck by the inferior type of humanity represented by the inhabitants of the mainland compared with those of the scogtia. The women here are especially brutish in appearance. They wear a long white garment with a sort of waistcoat over it, and a white head-covering. This would be all very well, were it not for the fact that it is generally filthy. It is true we arrived on Saturday evening, and I noticed a great difference the next day; whence $I$ infer that they are put on clean for the festa, and last the week out.

Zablace is in many ways a neglected spot. The Austrians call Dalmatia "the half-forgotten country," and surely this can be called " the quiteforgotten place." It even has no priest, nor has it any school. Indeed, there may be said to be no church, even the small octagonal chapel by the landing-place being the private property of the local family, and there is rarely any service in it.

Here also there are marshes, or rather lagoons, which, being salt, do not make the place in any way unhealthy. In Venetian times it was a 
centre of the salt-collecting industry, several of the lagoons being arranged for the purpose.

We found the new camp convenient enough, though the road to the village was auful. The only thing we had not was a spot to bathe, though I did so once where the things had been landed. This mattered little, for our hospitable resident kindly placed his bathing-hut at our disposition. Indeed, it was with the greatest difficulty we could avoid being transported nolens volens into his garden, tent and all.

Our first day, as usual, was employed in "settling in." I had every reason to congratulate myself on having found a spot for camp, for I do not think it would be easy to find another. Like most of the coast and island vineyards, the land (!) consisted of parallel ridges of rock. When in cultivation, every spot between these is occupied by dwarf vines. All the movable stones had been piled up in the manner I have before described, partly in a great dike to seaward. This was at once an advantage and the reverse. It shut us off from the sea, but it added to our privacy. Behind the tent again was another great cairn. Fortunately for us, the rocks all around were full of great cracks which would hold a tent-peg, for there was no soil which would have done so. Indeed, it was by the greatest luck we found a spot where the centre iron went down 
easily. I should perhaps explain that the balloon tents have no pole; a tackle holds down the apex to an iron driven deep into the earth. We learnt afterwards that the spot where our tent was placed had once been a well, supplied, of course, by infiltrations of sea-water, but used for watering the cattle, nevertheless.

The nature of the land and the want of water are the two drawbacks to camping in Dalmatiaboth, as our experience shows, to be overcome with patience; only the latter generally prevents one's going more than half a mile from a village. As for the former, it must be owned that we made a great mistake in bringing wooden tent-pegs; they should be iron. In this particular camp perhaps wood did better.

Our first excursion from Zablace was naturally Sebenico. We made use of our usual conveyance - a fishing-boat-to get there. We had an easy run down to Fort Nicolò. This work has been somewhat modernized, but of course the days of stone fortifications are over. The old gate-a replica of the Porta Terra Ferma at Zara-has been spared, and above it the lion of St. Mark still recalls the days of the great Medirval Republic. Perhaps the most interesting part of our voyage was the rock-bound channel which leads to the splendid harbour. Although very narrow -so much so as to make it almost impossible for 
two large steamers to pass each other-it is of great depth. At its inner mouth are the ruins of two small towers, between which the Venetians were wont to stretch chains to exclude hostile galleys. All this part of the two small peninsulas, which form the arms, as it were, of the harbour, have recently been planted with trees-the seapine, as they call it here. It will much improve the effect, but, as the tree is a slow-growing one, not for half a century or so.

Excepting its cathedral, a very fine fifteenthcentury building, Sebenico contains little of interest. We were mostly concerned to get a month's English papers and letters which we found awaiting us. Although a town of eight thousand inhabitants, Sebenico contains no bank, and it is almost impossible to get English banknotes changed here. I was offered eleven florins per pound sterling, and, as the exchange of the day was not much below twelve and a half, I need hardly say I declined the offer. On our return we unfortunately had a very high and contrary wind, so that our homeward voyage took us nearly three hours, whereas we had gone in in seventy minutes.

On the Wednesday (September 5) our hospitable neighbour - it is useless to expect to maintain his incognito, for throughout Dalmatia Zablace is unmistakably identified with the name of Fontana do Valsalina-invited us to a, to my mind, far 
more interesting excursion. A couple of hours' pull took us to an ancient fortress, possibly unique in construction, which goes by the name of Sebenico Vecchio. It consists of a peninsula jutting into the sea, and fortified at the neck by a high crenelated wall. This was originally flanked at each shore by a small tower. The wall, which narrows upwards from its base, follows the outline of the hilly ground, and is provided with a "berm" of stone slabs built into the wall for its defenders to stand upon, but the original means of access to this have disappeared. The peculiarity of this fortress consists in the fact that, like a modern fieldwork, it contained no living accommodation, unless a few rude stone huts, such as are common as weather-refuges throughout Dalmatia, can be so styled. It was intended as a refuge when the Turks came down, and in places are still to be seen the perforated stones by means of ropes passed through which tardy Christians could be pulled up to a place of safety, for the wall had no gate. Considering its antiquity, the perfect state of preservation of the wall is extraordinary. Only the northern tower is wanting.

From Sebenico Vecchio half an hour's sail brought us to Crapano, known to the ancients as the last of the Liburnian Islands. It is, however, more interesting from the fact that it is the only one that can be said to be wooded, the 
monks of its convent having kept it planted with magnificent pines. By the way, this sea-pine produces an edible nut, which, although it seemed to me rather turpentiny to the taste, is much usad in Dalmatia to flavour sweets. The bark has also a commercial value, as it yields a dark brown dye, principally used for fishing-nets. Although the island could not support eight people, it has eight hundred inhabitants. These live partly by the sponge fishery-we were shown a specimen of perfect sponge three feet in diameter-but principally by cultivating the adjacent mainland. They are not, like their neighbours the Zlarin islanders, engaged in the coral fishery. Considering there is not a drop of water in the island, and that when the rain-water runs short the inhabitants have to go to a spring above Sebenico Vecchio, this struck me as an extraordinary survival of habits acquired by their ancestors in the days when the Turk was an ever-present terror.

Neither is there any water at Zablace, but Cavaliere Fontana kindly allowed us to avail ourselves of his ample supply of rain-water. The peasantry use a well, the supply in which is the resultant of the infiltration of the sea, from which it is a considerable way off. I tasted the water, and found it distinctly salt, but it is said to quench the thirst, and also to be wholesome.

The Cavaliere has made several attempts, with 
more or less success, to increase the prosperity of Zablace. His greatest idea was to recommence the old Venetian salt-producing industry. After almost endless delays and correspondence, the Austrian Government sanctioned the undertaking, provided the salt produced was not sold in Austria nor in any country supplied by Austria, so as not to interfere with the government monopoly. This, of course, was prohibitive. Signor Fontana, however, was not discouraged, but, turning to the next best thing, proceeded to bring the old "saltings" under cultivation. The result of hard work and expensive drainage is that a large tract of useless land is fast becoming productive vineyard.

Another of his ideas was the improvement of the oil-producing methods. This has been a triumphant success, and the Zablace oil is now the best in Dalmatia.

The wine also has been much improved. As a rule, however, Dalmatian wine does not appeal greatly to the English palate, being both sweet and fiery. It must be admitted, nevertheless, that it is very inexpensive, good sound wine costing twopence a bottle. These low prices are of recent origin. The admission duty free into Austria of Italian wines has been a sad blow to Dalmatia, and has brought down prices immensely. The best ordinary wine is that made in the island of Lissa. In the Sebenico district there is a celebrated wine 
called Maraschino, which is made from a small white grape, and must not be confounded with the better-known liqueur of the same name, which is mostly made at Zara. Of the fifty different kinds of Dalmatian wine, the most celebrated, and also the most difficult-indeed, I might say impossible - to obtain is the Malvasio of Ragusa. 


\section{CHAPTER VIII.}

The Cavaliere is also a pillar of the Slav party in Dalmatia. Austrian politics are always difficult of comprehension to the outsider, and in this province they seem more puzzling than usual. The truth of the matter is apparently this, that they are really rather a farce. There are three parties, the Slav, the Serb, and the Italian. The latter, which is by far the least important numerically, is, not unnaturally perhaps, the most noisy. Its objects are less actual union with the present kingdom of Italy than to obtain a preponderance in Dalmatia for the Italian language in official matters, schools, etc., which, as the Italian element amounts only to some twelve per cent. of the entire population, is decidedly ridiculous. However, as the party returns only some five deputies to a Provincial Diet of forty-two (and one to the Imperial Diet), it is a quantité negligeable. The Serb party are the Greek Catholic Slavs. This party is more important in numbers, and also, for some singular reason, receives the support of the Roman Catholic Slavs of the Ragusa district. Even with the support of these and of 
the Italian "item," it is, however, powerless, the Slav party being in an absolute majority over them all combined. Therefore the government must, as racing men say, "stand on velvet" to a much greater degree than our own prime minister does at present," and, barring an unforeseen "cave," they have nothing to fear.

The Vienna Government, true to its policy of divide et impera, encourages these ridiculous provincial politics, and backs first one party and then another, with the idea that as long as a province is busy with internal dissensions it cannot actively develop the dislike which all Slav races undoubtedly have for the German rule. There can be no doubt that but for the religious dissensions in these provinces Vienna would have a much harder task, and this greatly explains the fact that we find so hard to understand of the continued coherence (if that be not too flattering an expression) of an empire confronted with so many racial difficulties.

Dalmatia is also intensely jealous of the expenditure lavished upon the "administered provinces," Bosnia and Herzegovina, and cannot see why these should be provided with railways, hotels, schools, haras, forest department, roads, and so forth, before a real old province of the empire which is badly in need of them all.

* Written' 94 . 
It also suffers from imperial politics, the absolutely necessary connection of its State railway at Knin with the Austrian system being persistently vetoed by Hungary, which hopes thus to coerce it into supporting the Magyar party in the Diet.* From one curse of Austrian politics it does not suffer-the Jew is conspicuous in Dalmatia by his absence. $\dagger$

If politics are so embittered, though puerile, in Dalmatia, they have this one great advantage, i.e. that they are kept out of the family. I know a family where the aged father is of the Italian party, but all his sons and his son-in-law are of the Slav way of thinking. Again, one of the latter's daughters is about to marry a young member of the Italian party. Yet, with all these differences of opinion, they are as united a family as one would wish to see.

\section{Before leaving Zablace I made another visit to}

* It is said that this line is really to be proceeded with now.

$\dagger$ This prècis of Dalmatian politics was compiled from information derived from Slav sources. It is, perhaps, only fair to add that the Italian party contend that they have the confidence of the Slav peasantry to a much greater extent than the actual constitution of the Provincial Diet would imply, and maintain that, but for the elections being greatly influenced by government officials, its composition would be very different. To put their contention in few words, it amounts to this: "Codlin's the friend, not Short." I must leave the reader to decide for himself as to which version of the story he will accept. 
Sebenico, on foot this time. On the road we stopped to visit one of those curious caverus with which South-West Austria (and notably Styria) is so liberally provided. The entrance to this one is a few feet from the high-road, under which it passes. Twenty feet from the mouth there is water-salt. When provided with a boat, one can traverse this and enter a gallery over a hundred and fifty yards long, which finally emerges in another cave with more water. This has not yet been crossed, because no boat can be carried through the small passage. It can be done any day by bringing in a raft piecemeal, and then perhaps a solution of the following question will be arrived at: How does the sea-water reach so high a level?

Our road led us to the south end of Sebenico harbour, not far from the place where the Imperial training ship Schuartzenberg has her permanent anchorage. Some people consider this the best view of the town, and it is certainly picturesque. Crossing the Knin and Spalatro Railway-a thing we had not seen for a month-we were soon in Sebenico. The day was a festa, but, to my surprise, amongst all the bunting so profusely displayed there was only one Austro-Hungarian flag. All the others were horizontal red, white, and blue, like the Dutch colours, only, as far as I recollect the blue is uppermost with them. 
"What are these flags?" I asked my companion, a young reserve lieutenant just back from the manœurres.

"The national flag."

"But not the Austrian. Do you mean the Dalmatian colours?"

"Well, it is the flag of the Slav party."

It is, I think, hardly necessary to add that our lieutenant belongs to the other side.

I inferred from this display that the Italian party in Sebenico is decidedly in the minority, and in this I was correct. I imagine, too, that they are very peace-loving, or this sort of thing might lead to trouble, as it often does in Spalatro, and recently did in Istria. Then I went and got my English papers, and read that the Union Jack had just been hissed off the stage at Cork. But even "the rebel city" is far more closely united to England than Dalmatia is to Vienna.

Having finished my business of laying in stores, I found a Crapano fishing-boat just about to start home, and in it I returned to camp.

The shooting at Zablace is at this season nil. In winter water-fowl, including wild swans, visit the saltings in considerable numbers. There is some shooting at Castel Andreis, seven miles to the southward, where there are marshes, but I did not go there. As usual, there are a few hares and partridges in the vineyards; but, although I 
took a few walks with gum and dogs, I did not fiud the game worth the candle.

The officers of one of her Majesty's ships once gave great offence to the good people of Sydney (N.S.W.) by posting up the following notice at the head of the ship's ladder one day they were entertaining the citizens: "We have seen your zigzag railway, and we consider your harbour very beautiful." In the same way the visitor to Sebenico will save himself much trouble and lingual fatigue by putting in his hat, "I have been to the Krka Falls," for it is the answer to the first question everybody you meet is sure to ask you.

The reader must not suppose, from the above, that I propose to disparage these well-known falls, although I am not prepared to endorse the remark of an enthusiastic citizen that they were the finest in Europe. Moreover, if they were, Europe is not much of a continent for waterfalls.

In order to see the cascade, one must go from Sebenico up the northern arm of the harbour. The most economical and rapid way is by diligence, which ouly costs fifteenpence each way. We, not being at Sebenico to start with, fell back on our Dalmatian hansom, the fishing-boat. The harbour continues to narrow, till all at once it turns sharp round to the right and expands into the lake of Proliljan. This lake is really more 
what the Irish call a lough, as the water is salt, and the tide ebbs and flows here. Then we enter the real river at Zatton.

Scardona lies a little way up the Krka. It is the oldest town in Dalmatia, though now little better than a village. Beginning by being a Liburnian colony, it was afterwards an important Roman naval station. Like most Dalmatian towns, it played its part in the Turkish wars, and took hard knocks. The Venetians, indeed, once levelled it to the ground, which, however, did not prevent the Turks from returning and remaining here till nearly the end of the seventeenth century. We were sorry not to have time to visit it or the old Roman ruin on the hill above.

Before we had gone much further up the stream we began to hear the distant sound of the falls, and ere long they appeared in sight. An irreverent observer has likened the falls of the Krka to rocks covered with linen hung out to dry, and it cannot be denied that there is something in the simile. The river makes five small leaps, a ridge of rock showing above the foaming water at each leap, but each of the five falls is divided horizontally also by rocks, so as to form scores of tiny cascades. As elsewhere in Dalmatia, the vicinity of the water is the cause of luxuriant vegetation, and it is this I think that gives 
Scardona and its falls such a reputation among the Dalmatians. A little higher than the falls the Krka forms a little lake, on an island of which stands the convent of Vissovac. It goes without saying that the Turks made short work of the worthy Franciscans, and the present building only dates from the end of their occupation. Want of time prevented our going any further. In its upper course the Krka forms another important and two minor falls. 


\section{CHAPTER IX.}

Ат Zablace we had two days' thunderstorms and showers, which materially reduced the temperature, and we had reasonable hopes that we had seen the last of the dog-days, for the heat, especially at night, had been rather trying. For the rest of our stay the weather was cool and pleasant, though rather windy. In fact, the 8th and 9th of September were decidedly cold in the early mornings, the bora bringing frequent showers with it.

We were somewhat loth to leave this Capua, as the hospitality we had received had really made it, but the day came when we felt we must move on. Our kind friends did all they could to speed the parting guest.

"Go by fishing-boat; and where to?"

"Well," I answered, "we thought of Rogosniča."

"Oh dear no; it will take you hours. We will write in and have the steamer stopped here either on Tuesday or on Wednesday."

So it was arranged. The former morning was 
wet, so the little steamer liugged the Zablace shore in vain that day. The next morning, however, at nine o'clock, we were lying off in a fishing-boat with our goods and chattels, awaiting her, the whole family waving adieux from the pier. Soon we saw smoke above the channel, then the masts, and finally a white hull rounded the fort and made towards us. In a few minutes we were aboard, and I found an old acquaintance in the captain, having once sailed with him from Stretto to Bettina, in the island of Morter. Indeed, it was he who, on that occasion, suggested Zablace as a suitable camping-place. I also made a new one in the shape of the priest of Rogosniča, to whom I had a letter of introduction, and who was returning home after two days' absence in Sebenico.

Crepano and Sebenico Vecchio were soon passed. A little later we stopped to disembark a couple of passengers on a little scoglia, where a lighthouse is in process of construction. Then the sea became more open. We could see Lissa, the scene of two famous sea-fights, and San Andrea still further away. By the way, is it not strange that to Englishmen the last fight should be "the battle of Lissa," whereas the engagement of the 12th of March, 1811, in which our English Hoste totally defeated Dubordieu's French squadron, was probably as big an affair, and certainly should be more interesting to us? 
Soon after ten we ran into the little port of Capo Cesto, where most of our passengers left us. This happens to be the police station for Rogosniča, and, seeing the inspector on the quay, I took my " circular note" to him; but he saluted, and waved it back. "Not necessary, not necessary, sir. I know all about it, and it will be all right." Sure enough we had not been an hour in camp before we saw a gendarme pass, and next day two.

The fact was that a paragraph had appeared in a local paper about us and our journey, and though I believe it was Indicrously incorrect (I was told I was described as a retired general!), it gave us a notoriety which was sometimes unpleasant, but perhaps sometimes useful. The interviewer has not yet reached Dalmatia, so the papers have to do the best they can without him. After all it is no great loss, I dare say.

Rogosniča-generally called "di Sebenico," to distinguish it from another to be referred to hereafter-is something like Milford Haven, "a magnificent harbour thrown away." A far easier channel than that of Sebenico-for sailing craft can beat in with almost any wind-leads to a magnificent circular anchorage. In the centre of this lies the village on a barren islet. Houses, crowned by a scarcely finished modern church, fringe the northern shore of the scoglia. Above all is a windmill, a novelty in Dalmatia. To the 
south is an anchorage which could easily accommodate a dozen line-of-battle ships; and beyond, again, two creeks run up in opposite directions. With such natural advantages, it is wonderful that the place did not develop more in the days of sailing craft, but the near vicinity of Sebenico and Spalatro kept it down. To the north of the village a beginning has been made with a causeway which is to connect the village with the mainland. At present the work is suspended, and the bridge seems likely to be replaced for an indefinite period, as at present, by a ferry.

After a consultation with the headman of the village, we once more embarked on a fishing-boat, and proceeded to the northernmost of the two creeks which I have above mentioned. At the end of this we found a convenient spot for the tent between three olive-trees. The situation was beautiful, and at night, when the water and the hills were lit up by a nearly full moon, it was perhaps more picturesque than any camp we had hitherto pitched. Nor were we much troubled by spectators, one reason being, doubtless, the distance from the village, and another, that, the vintage being in full swing, all hands were fully occupied. The creek afforded a capital bathingplace, but drinking-water had to be brought from the village.

The quail were "in" when we reached this 
spot, and all day long the hills echoed to the pop-pop of the natives' long-barrelled guns. I went out once or twice, but only found a few birds. The local sportsmen-and there are a great many too many of them--beat every inch of the ground like well-trained dogs; and this is decidedly hard work, as the hills are rough and rocky. For this reason my short-legged dogs were not much use. Besides, they had had a very dry summer here, and consequently there was little or no scent. Here, as elsewhere, the land, though mostly out of cultivation other than a few scattered olive-trees, is divided by high stone dikes, and most of these consist of only one row of stones, which makes it difficult to get over without toppling half a dozen stones after one, and both $I$ and the dogs suffered from injuries so caused.

As had already happened at Morter, Ekilled a scorpion close to the tent here. They seem common in Dalmatia, but nobody troubles about them. I saw some snakes about, as I had also done at Pasman, but they were all cornmon green ones. The great nuisance were the sandflies. These look just like a common house-fly, but bite very hard, generally selecting one's ankle. Fortunately the bite has not any aftereffect, as, for instance, a mosquito's has.

The camp was a pleasant one, and it was with 
some regret that we decided to spend only three days here; but my cousin, before referred to, wrote that he was anxiously expecting us at Spalatro. As there is only one steamer a week, we had either to leave the first day or to stay ten days, which, having regard to the advancing season, was more than we could devote to Rogosniča.

Accordingly on Saturday, September 15, our camp was struck at noon, and we pulled off to the island. An hour was devoted to the enjoyment of the priest's hospitality, and then the Lloyd steamer arrived and tied up to a buoy a hundred yards from shore. It is unfortmuate that the village should have been constructed at a spot where the depth of water does not enable large steamers to approach the quay, as there must be plenty of these round the islet. We left at halfpast three, and soon rounded the Punta Planka. This is the most westerly point of the Dalmatian mainland, and has an evil reputation for dirty weather. From here Lissa and San Andrea were again plainly visible. The latter is the furthest scogtia from land, with the exception of the Pelagosas, which, being halfway across the Adriatic, some time ago formed a bone of contention between Austria and Italy. Strange to say, not loug ago a number of skeletons, surrounded by relics of the Stone Age, were found upon these. It is a 
well-known fact that means of water-transport were almost unknown at that period, so it has been conjectured that these may have been survivors of the cataclysm which rent all the islands away from the mainland. More strange than all, one of the skeletons was found to have a stone knife embedded between the ribs-a silent record of prehistoric crime perhaps unequalled in the world's annals. To what conjectures does it not open the way, this long-forgotten deed of violence?

Soon after five we made fast at the quay of the curious old city of Trau. It has been well said that "Tran within and without gives one the impression of a mediæval Venetian city." Although it was one of the principal Venetian settlements in Dalmatia, it is of course of far greater antiquity, having been a considerable town for centuries before Christ (the Roman Tragurium). The harbour fortifications are Venetian, but the round tower, which is equally conspicuous, is older, having been built in the second half of the fourteenth century as a defence against Venice. Everything else about the place is pure Venetian-the townhall, the loggia, the Cippico Palace, the many churches. Chief among these is the cathedral, without comparison the finest ecclesiastical building in Dalmatia. Everything about it is worth seeing. The entrance door with the colossal circular window above, the marble 
chancel, the high altar, and the exquisitely carved choir seats. The fine chapel of St. John Ursinus, Bishop of Trau in the eleventh century, is a place of pilgrimage. A drawbridge connects Trau with the island of Bua. The channel is planted with trees, and altogether the place is well worth a visit.

But our short time is up. Our boats and ladders have been in-rigged, the drawbridge swings round, and we glide through, leaving behind us a never-to-be-forgotten scene of beauty-the sun setting behind the old Venetian towers and ramparts.

An hour later we received a hospitable welcome to Spalatro. 


\section{CHAPTER X.}

IT is indeed hard to write of Spalatro, and yet to keep one's resolution not to write guide-book. How can one speak of it without mentioning its many interesting monuments? The town is really all one antiquity, being as it nearly all is, at least the oldest part thereof, built in and of the enormous palace of Diocletian. To us the first day at Spalatro was pure delight and surprise. Being a Sunday, the narrow and quaint alleys were crowded by country folk in every variety of quaint costume, and among them we wandered, noting at every turn strange old-world walls, columns, and bits of ruin. The very cathedral is a Roman temple, dedication uncertain, but probably intended ultimately for the apotheosis of the imperial designer, and the baptistery another.

One sight I may perhaps allow myself to describe, and that is the view from the top of the hundred-and-fifty-feet-high campanile of the cathedral. One could pass hours there picking out the various bits of life below, which contrast so 
quaintly with the Roman ruins. This tower, which is a Vandalism, being principally constructed with pilferings from the ruins of Salona, has been for the last ten years undergoing restoration-a work which will require ten more, and involves vast expense. The existence of the scaffolding gives one a unique opportunity to examine the basreliefs and carvings with which the thievish constructors beplastered their anachronism ; but one can only be lost in wonderment that the opportunity was not utilized to remove the tower altogether. In its present position it utterly ruins the principal front of the temple-probably a unique specimen (unless, perhaps, I except the little temple at Rome, so long known as that of Vesta), on which, too, it is now proposed to expend a large sum by clearing away the wretched houses which have sprung up around and almost in it. Moreover, now a design has been mooted of building a new cathedral altogether, and preserving the magnificent temple as such. This is from every point of view desirable, as the cathedral is too small for the town. But if it is carried out, what about the tower?

Be this as it may, the view from the top is magnificent, embracing as it does everything between the higher hills and the island of Brazza. As I have before said, it gives one an idea of the old city and palace which, to my mind, no amount 
of walking about can do. I am, however, not sure that it is at present open to the public.

The other churches of Spalatro are noticeable only from the fact that half a dozen more utterly hideous and tasteless sacred edifices it would be impossible to find in a western city in the States.

Spalatro has of recent years outgrown the limits of the old palace, and forms three large modern suburbs, which contain, not unnaturally, nothing of interest. I may perhaps, as my kinsman is its superior, be allowed to except the handsome building the Society of Jesus has recently built. It was, however, not by any means completed at the time of our visit. When it is finished it will be worth a visit, if only for the sake of one picture to be hung in the chapel-a Crucifixion. The real meaning of the Great Sacrifice is generally obscured in art by such accessories as beautiful women, disciples, soldiers, doves, or haloes of glory. Here it is not the case. The picture represents simply the dead Christ hanging on the cross in a position into which a last contortion of agony has drawn him. The wounds are wounds, not the neatly dressed injuries with which painters have made us familiar. In short, the picture is reality without approaching the repulsive realism of Gay, whose picture has recently been brought before the British public. The artist's name, nay, even the school or date, is unknown. 
An Englishman recently offered to cover it with sovereigns to have it, but the owner preferred that it should remain as a stimulant to devotion in his native town.

Next day being market-day, we made our way to the place in the hope of seeing some quaint figures, but upon the whole we were disappointed. Many of the peasantry nearer the town wear the usual little cap in black, and dark-coloured clothes, braided somewhat after the Hungarian fashion. The hillmen often wear the baggy Turkish trousers, and some few the turban, the first we had seen. Some also wear the cumbrous leather belt, which a friend of mine recently described well, as " a sporran higher up than usual," universal in Montenegro and Albania, and indeed in South Dalmatia and Herzegovina. In the two first-named countries, however, it is chock-full of weapons, and even here I noticed some with the forbidden revolver, ${ }^{*}$ and more with the knife. The women of Spalatro are distinctly better looking than those of Northern Dalmatia.

By the way, I write Spalatro as more familiar to me, but hero they call it Spalato. These Italian names in a Sclavonic country are an anachronisma concession to an infinitesimal majority-which should be abolished. My letters are post-marked in two languages, thus: Zadar, $\frac{\text { Sibenik }}{\text { Zara }}$ Sebenico $\frac{\text { Spljet }}{\text { Spalato }}$. Which should I follow? Ought I to write Rogosniča or * Forbidden, that is, to those not provided with a porto d'arme. 
Rogozuizza? As a matter of fact, I fear I have followed no distinct rule, except in the case of the larger towns, which are only known to us in England by their Italian names; but I have a strong feeling that the Austrian Government should make up its mind once for all, and, as far as an outsider can see, it should be for the Slav language. Hard as it may seem to replace Ragusa by Dubrovnik, the Latin race has had its day in Dalmatia, and it was a long one.

When one has exhausted the relics of Roman days, there is little to be seen in Spalatro itself. There are, however, plenty of excursions to be made, and the particular one which I fancy no one omits is that to the ruins of Salona. In olden times Salona was the town, and it was not till the Turks rendered it untenable that the inhabitants bethought them of the solid walls of the old palace, and, crowding into it, formed the modern city. Those walls proved a nut the Turks never could crack, and Spalatro remained "La Pucelle," as a certain French city was till one Malbrook happened to pass that way. It never was taken, but, as a consequence of the treaty of Campoformio, peacefully surrendered into Austrian hands, in which, when the Napoleonic troubles were finally settled, it remained.

The interest of Salona is of course principally archæological, and neither of us can claim to be 
that, but the road to it and the modern village are not unpleasing. The former runs along a ridge overlooking the harbour of the ancient city. On a spit of land running out into this lies Vranjic, otherwise known as "the little Venice." This epithet is said to have arisen from its situation, but for our part we could see little or nothing to remind us of any part of the Queen City of the Adriatic, unless it were, perhaps, a certain suggestion of one view of the Giudecca in the arrangement of some of its buildings.

To us, after six weeks of Dalmatian rocks and crags, the modern village of Salona, with its purling stream, green meadows, and fine trees, afforded great pleasure. There is something very suggestive of an English trout-stream about the River Jader, as one looks up-stream from the old stone bridge. It was this river which the Emperor Diocletian utilized to supply his palace with water. His stupendous aqueduct has recently been restored at great expense, and in consequence Spalatro has now the best water-supply of any Dalmatian town. The reservoir, which is on the Salona road, although a modern building, is surmounted by a fine medallion of the emperor-a rare instance of tardy gratitude. It is, however, rather strange to find a Christian community erecting a memorial to one of the most active of the ancient persecutors. But Spalatro owes more than her water-supply to her 
illustrious townsman.* Her very existence is due to the solidity of his palace walls.

Modern Salona consists principally of wineshops, the stone tables outside of which are simply composed of a slab taken from the ruins laid on the capitals of two ancient columns. At one of these, where the table-legs were an exquisite design of acanthus leaves, we stopped to rest beneath a magnificent row of sycamores. I fear the tourist has rather demoralized the Salonitans, for at this primitive hostelry we were charged for bad wine double the price of good. But then one can hardly make a row at being charged twopence halfpenny a bottle instead of half that sum.

Before leaving Spalatro it became necessary to decide on our future plan of action. The original itinerary which I had sketched out was Brazza, Lessina, Curzola, and so on. These islands, though interesting in their way, afford nothing new to those who have already visited the more northerly ones. Brazza is, after all, only a larger Morter; and even Lessina, though it has some beautiful scenery, is very much the same. So we finally decided on following the mainland in future.

Some fifteen miles south of Spalatro lies the little town of Almissa or Omiš, which is situate at the

* Of course, I here take Salona to be the forerunner of Spalatro. 
mouth of the river Cettina. Small republics were formerly the fashion in this part of the world, and Almissa was the chief town of that known as the Poglizza. Its burghers were astute enough to accept the suzerainty of Venice, and so preserved their nominal independence. This state of things continued down to the present century, when the French refused to acknowledge the little republic, and enforced their conscription at Almissa. Russian emissaries stirred up a revolt, which was soon quenched in blood. The last "doge" fled to St. Petersburg, carrying with him the archives of the little state, and there he died. When the country passed a second time into Austrian hands, the question of the ancient privileges, which they had previously respected, was allowed to lapse. How an antonomous republic arose out of the nest of Illyrian pirates Almissa, in common with every other harbour along this coast, became after the collapse of the Roman empire, I know not. Perhaps the missing archives would help to elucidate the matter, but they are doubtless hopelessly lost.

We decided to pitch our next camp in the vicinity of Almissa, but not too near it, as we feared the amount of sightseers from a place of a thousand or more inhabitants might prove a nuisance. As the event proved, we were less troubled there than almost anywhere else.

Accordingly, having slept on board, we left 
Spalatio at half-past four on the morning of the 22nd of September by the Austrian Lloyd steamer Messina.

Her first port of call was San Pietro, in the island of Brazza. This is, if not in actual measurement the largest of the Dalmatian islands, the most considerable, because it is compact, whilst Lessina and Curzola are narrow strips. It is probably also the most uninteresting. From San Pietro the steamer turned back at an acute angle, and in less than an hour the steward knocked at the cabin door, and said, "Nearing Almissa, sir." 


\section{CHAPTER XI.}

"This is the prettiest place we've seen yet," said $\mathrm{E}$ - to me, when I joined her on deck. But Almissa is more than pretty-it is stupendous.

Imagine a long line of bare rugged limestone cliffs, the hindermost points rising to several thousand feet. Through these the river Cettina, after running parallel to the seashore for no less than ten miles vainly seeking an outlet, has torn its way, forming a gorge exactly the shape and size of the Brêche du Roland in the Pyrenees, but to which the background gives more the appearance of an Afghan pass. On the right bank of the river lies Almissa. It is not noteworthy in appearance, the old walls being gone. The Cettina, by forming extensive shoals all round its mouth, has cut the town off from the possibility of access for steamers, which can only lie half a mile to the southward. Across the stream is an extensive building half hidden by fine trees, from which green marshy meadows run down to the river mouth.

We had got so thoroughly accustomed to look 
to the Church for temporal as well as for spiritual assistance in Dalmatia, that it came natural to us to wend our way to the priest's, and ask his advice about camping. It is true I had a letter of introduction to him, but I have no hesitation in saying that any one who may follow in our footsteps with nothing of the kind, will receive as cordial assistance and hospitality from the Dalmatian clergy as we did. This time our clerica very kindly and genial gentleman-had very decided ideas as to the best place for a camp.

"The old seminary at Priko," said he; "that's the place. You will be quite private there, and it's only a few minutes from the town. Come and see."

In a few minutes we had crossed the river by a ferry, and turned off the Spalatro road up a fine avenue of poplars and pomegranates leading to an old gateway.

"Here you are," said our friend. "This is the old seminary, disused for many years, and in my charge. Pitch here in the courtyard, if you like, between the seminary and this old churchninth-century Byzantine, by the way. Show it you another time.-Here's a well, you see. Water? Well, it is brackish; but here's the custodian of the seminary, who'll do everything you want, and fetch you drinking-water from another well quite near. Or, if you like, you can camp in one of the fields; but here you can shut the gate whenever 
you want to be left in peace. Come and see, though."

So we went and saw; but decided that the fields were too marshy, and that nothing could beat the paved courtyard of the seminary, and in about an hour the Union Jack was floating there.

"High-road first, then ploughed field, islet, cemetery, well, and now seminary," quoth E-. "Where shall we camp next?"

As will appear hereafter, our next camp was perhaps as strange as any.

From the deck of the Messina I had that morning seen a large number of teal just where the Cettina joins the sea. Thinking that perhaps some of them would resort to the marshes or swampy fields to feed, I strolled out to the point towards sunset with gum and dogs. Not a duck was to be seen, however. A solitary white wader -species unknown to me-was solemnly feeding round the shores of a reedy islet, but he took good care to keep his long-legged carcase out of shot; not but what he would have been perfectly safe for me had he been less cautious.

Most of the reeded banks are impossible of access. The dogs worked all that was dry enough to get through, but only moved a kingfisher. This was the first I had seen in the country, though I saw plenty at our next camp. So I strolled back again. 
Round the gigantic conical rock behind the camp a pair of ravens were flying and croaking. Though so rare with us, the raven is not uncommon in Dalmatia. A solitary bird used to pay us a visit every day when we were encamped on St. Justina's Isle. Probably he was searching for shellfish among the rocks.

Fly-fishermen should have a chance in the Cettina. As I walked back the river was alive with rising fish, many of them of very considerable size, of which I was the better able to judge from the fact that nearly every rise was clean out of the water.

I suppose there is no camp without a drawback. In this particular one we suffered from a perfect plague of flies. After all they are, perhaps, less objectionable than mosquitoes. These really only troubled us once during our trip at Rogosniča, where there was a dirty pond a couple of fields from our camp. They were also bad in our rooms at Spalatro; but as a rule one may say that there are none in Dalmatia, because there is no fresh water.

Next day we had a caller in the shape of our neighbour the curate, who lives alone in the disused seminary. He had the little church opened for us. Beyond the undoubtedly Byzantine dome, it contains nothing of interest excepting a twelfthcentury painting in the sacristy representing all the Stations of the Cross on one canvas. Picture 
and frame are alike desperately in need of restoration. Almissa is another place the Turk failed to subjugate, but it was less to that fact than to its isolated position, covered as it is by mountains and by the river, that this little church probably owes its immunity from sacrilege. It is said to have played its part in some stirring scenes of Slav history. There is a still more ancient church in the town, but only the walls are left. The fine church of Almissa is modern.

This was the first camp we had pitched away from the sea, and consequently we found some difficulty in getting a spot to bathe. We had to follow the Cettina to its mouth to do so. There we found a huge rock, cultivated on the land side, which ensured privacy, shutting off as it did the high-road. The bottom was sandy, but the water was rather shallow, and not very salt. To the former drawback we had become used at Spalatro, where the depth at the bathing-place averages about eighteen inches for the first forty yards from shore. By the way, I had a great fright there one day, comic enough now, but very serious at the time to me. It happened thus. But first I ought to explain that of recent years sharks have been seen at intervals in Dalmatian waters. No one has been injured by one, nor do they constitute any real danger to bathers, as Jack Shark has little liking for shoal water. The Dalmatians 
attribute their visits to the existence of the Suez Canal, which seems to me more than doubtful. Nearly a score of years ago I saw a couple of large white sharks in Gibraltar Bay; and, unless my memory deceives me, Marryatt, always accurate in sea matters, describes men being taken by sharks in the Mediterranean nearly a century before the canal was opened. Be this as it may, they are to be seen at intervals in the Adriatic now, and it is that sort of fact a bather doesn't forget. One very rough day I had swum out to take a header off a stage some seventy yards from shore. I was swimming back-slowly because it was hard work getting through the rollers-when I happened to glance over my shoulder, and there, some little way back, was the well-known triangular fin. To judge from my feelings I must have turned green, and I put some record work into the next few yards. Presently I had another look back for the fin, for of course a shark doesn't mean business till that disappears. This time, however, I must have been on the crest and not in the hollow of a wave, for my shark-fin had turned into the tip of a dark-coloured lateen sail, and as I slid into the trough of the sea I saw exactly what I had seen before, but this time with very different feelings.

Through the pass run two roads, one on each bank, and both more or less overhung by the cliffs 
towering above. That on the left or town bank is driveable for some seven or eight miles, and is to be continued to connect with the central road system and so on to the Herzegovina. The pass is some half-mile long, and the river valley opens out, green and smiling, beyond it. Needless to say, we explored them both. At this time both, but especially the nearer one to camp, were full all day long of muleteers bringing down their pack-animals loaded with skins full of new wine. These men carry quaint little whips, suggestive of the American Indian's quirt, but with the short wooden handle ornamented with brasswork. The thong is attached to two or three links of chain, and the whole thing, when not in use, is thrust into the belt.

The road on the north bank is never more than a mule-track, and leaves the river directly the pass is traversed. The other, however, is a fine road, and evidently of quite recent construction-in its present condition, at any rate. Unfortunately, it leads nowhere, for, after following the river some seven or eight miles, it suddenly degenerates into a mere mule-track. This leads to Duare, of which more anon. As I have just said, it is to be continued some day. Just at present, what seems to be more wanted is a bridge to carry the Spalatro road into Almissa. There is a diligence twice a day, but its journey ends at the river-side, and the 
crossing has to be made in an open ferry-boat. The unfinished road winds along the banks of the river, passing always alongside of, and sometimes under, gigantic barren crags. About three miles up the Cettina it makes a sharp bend to the northward, and several reeded and wooded islets come into view. At this point, and indeed at several places on this road, the Dalmatian stream has more than a suggestion of some of the wilder Derbyshire rivers. Four miles from its mouth is all that can be travelled by boat, for then comes the first mill-dam. This mill is considered quite a show place by the good people of Almissa, though to our ideas the buildings are a bit cockneyfied. There are, however, some noble trees, and the whole has a pleasing aspect, especially to eyes satiated with Dalmatian barrenness.

The weather was not kindly to us during our stay at Almissa, and, as will appear hereafter, it kept us there twice the time we had intended. The first week, however, we had more fine days than wet; but when the rain did come it came in the shape of thunderstorms, which, however grand, are a decided nuisance in camp. One that we had was simply terrific. The lightning seemed to leap from crag to crag, whilst the thunder shook the peaks above us, and made sleep almost impossible. Sure enough, next morning a large clean patch on the face of the weather-worn rock behind us 
showed where the levin bolt had struck, dislodging some half a ton of rock in so doing.

Besides this, two fine days were lost to us for exploring purposes by my being weak-minded, or perhaps weak-bodied, enough to get a dysenteric attack which left me hors de combat for that space of time. How or where I contracted it remains a mystery, but the climate of Almissa is a little trying, as the bora always blows through the pass at sunrise, thus producing a sudden fall of temperature after a hot night. "Sunrise" is perhaps hardly the term to use here for daybreak, as the orb of day does not top the great cliffs till a couple of hours later. For the same reason, the town loses an equal amount of sun in the afternoon. Of course, the Almissites put my indisposition down to our mode of life. "What can people expect who bathe in the sea in all weathers, and sleep in the open air?" 


\section{CHAPTER XII.}

There is a fine old castle at Almissa, which I fancy few people have seen. It is invisible from the town, and even from the sea it only looks like another of the towers that crown the cliffs. To see it one must either go up to it (over a thousand feet), or, better still, climb one of the higher hills facing it. The way I first came to see it was this. The first day I felt fit for a walk again, I left camp rather late, a little before four p.m. It was a Sunday, by the way; but in Dalmatia, after mass has been duly attended, we make but little difference between that and any other day. The afternoon was close and dull, with frequent thunderstorms. I went through the pass on the north side, and climbed the hill which closes in the pass when it is seen from the sea. It was hard work, being mostly covered with hill vineyards; but when several hundred feet were left behind I reached an oak wood, from whence a splendid view of the ruin as well as of the valley was to be had. A couple of magnificent white-tailed eagles were 
wheeling above me, and, indeed, Almissa seems to be a paradise for birds of prey.

The ascent of the oak-covered piece took some time longer. To my right I could hear the roaring of a waterfall, where in wet weather a single leap carries the water from a cleft in the hilltop almost down to the village of Zakusač, little, if at all, above sea-level. On emerging, I came upon three or four Morlalis herding sheep and conversing loudly. Consequently I was thinking of nothing less than shooting, when all at once an eagle swept over the hilltop within five yards of me. He had increased the distance to thirty-five before I had "unslung arms" and fired; nor was it till I saw the feathers fly under the wing at the crack of the Schultze that I recollected that my larger shot (though all too small for such a quarry) were in the left barrel. I fired again, but though the eagle was obviously sick, he held on down towards the valley, and I never saw him again. One eagle remained soaring alone for some time over the castle, but whether the imperial bird had succumbed to my shot, or, as I incline to believe, they had parted company before I saw them the second time, I shall never know.

I was, and am, rather ashamed of this shot, especially as I have so often preached against the wanton spirit which causes the home gunner to desire to bring down every rare bird that visits his 
neighbourhood. I can only urge in extenuation that I had not had a chance to "loose off my piece" for over a fortnight, and was suffering from the natural desire to kill something. Moreover, eagles are by no means rare on the Herzegovinian frontier. I haven't much doubt that my dogs were the object of the swoop I certainly ought to have intercepted. Very likely the big bird mistook the hare-pied "Waldmann" for puss herself, but of course instances of eagles taking dogs are common enough. I recollect one some years back on the Anglo-Scotch border, when two ladies lost their pet for ever and aye.

Behind the bill I had climbed another rose to half the height again, being mostly perpendicular rock. Much as I desired to ascend that too, the sinking sun warned me to desist; so I pressed on northwards to a village $I$ could see in that direction.

Just before I reached it, having diverged slightly from the track, I came upon a viper. It was a different species to our English one, but the shape of its head told too plain a tale for honesty. It was torpid from the change of temperature, but when $I$ touched it it bit at the gun-barrels, and at once put itself in the well-known position of defence. The dogs seemed anxious to investigate, so I put an end to it, and for that shot I do not desire to offer any excuse. This was 
the only undoubtedly venomous snake I saw in Dalmatia.

The sun was all but gone when I reached the hamlet, whence one of the most infamous tracks I had traversed in Dalmatia-and this is saying much-zigzags down to the river, a short walk along which brought me back to camp. Before I got there, there passed me with courteous greeting two mounted monks-a sight which carried one back to the Middle Ages at once. The worthy brethren were well mounted too, and quite at home on their sleek and spirited palfreys. From an idea, perhaps, that spurs are hardly clerical, they used large stirrups not unlike the Turkish ones, the sharp corners of which one used smartly when his cob shied at my dogs and swerved across the road.

The next afternoon I was out on the hill again, but though I worked a lot of ground higher up, it was only to experience another blank day. But the explanation was forthcoming. I had secured the services of a local sportsman, Ante by name, and the next morning he and I were off at seven, and, as it turned out, to the same ground where I had first been.

'The Morlaks' method of shooting is very simple. They go out at daylight and listen for the stonehen's calling. Thus they know exactly where to try, and this is important, for the coveys are not 
so thick as in Greece or in Herzegovina. On this occasion we met a woman herding sheep, who said she had heard them on a certain mass of rock. Sure enough, the dogs soon began to be busy when we got near it. Unfortunately, my guide did not think sufficiently abort me. He and a boy whom he had called up hurried on, and I could not keep line. The Morlak does not look very smart with his extraordinary baggy nether garments and huge raw-hide sandals, but he is expert and active among his native rocks, and I, who claim to be a fair cragsman, was quite out of the hunt with my nailed shooting-boots.

The result may be imagined. I was behind a rock when I heard a whistle of wings-a "rise" unfamiliar to me.* Then my man informed me the birds had risen on his throwing a stone into some bushes-first five, then a single bird, then a brace, and lastly one more. He thought he knew where the two were, so I waited for a driven shot whilst they beat out the rocky ridge. They failed, however, to move the birds; but Ante said he had a dead mark on a single bird, and thought he knew where three were. I elected for the certainty-

* This is a subject on which more might be written. I maintain that the "rise" (the whirr of wings with which most of the Gallinacer, and other birds, get up) differs with each variety. An observant sportsman should be able without difficulty to name the bird which gets up belind him, provided, of course, he is familiar with the species. 


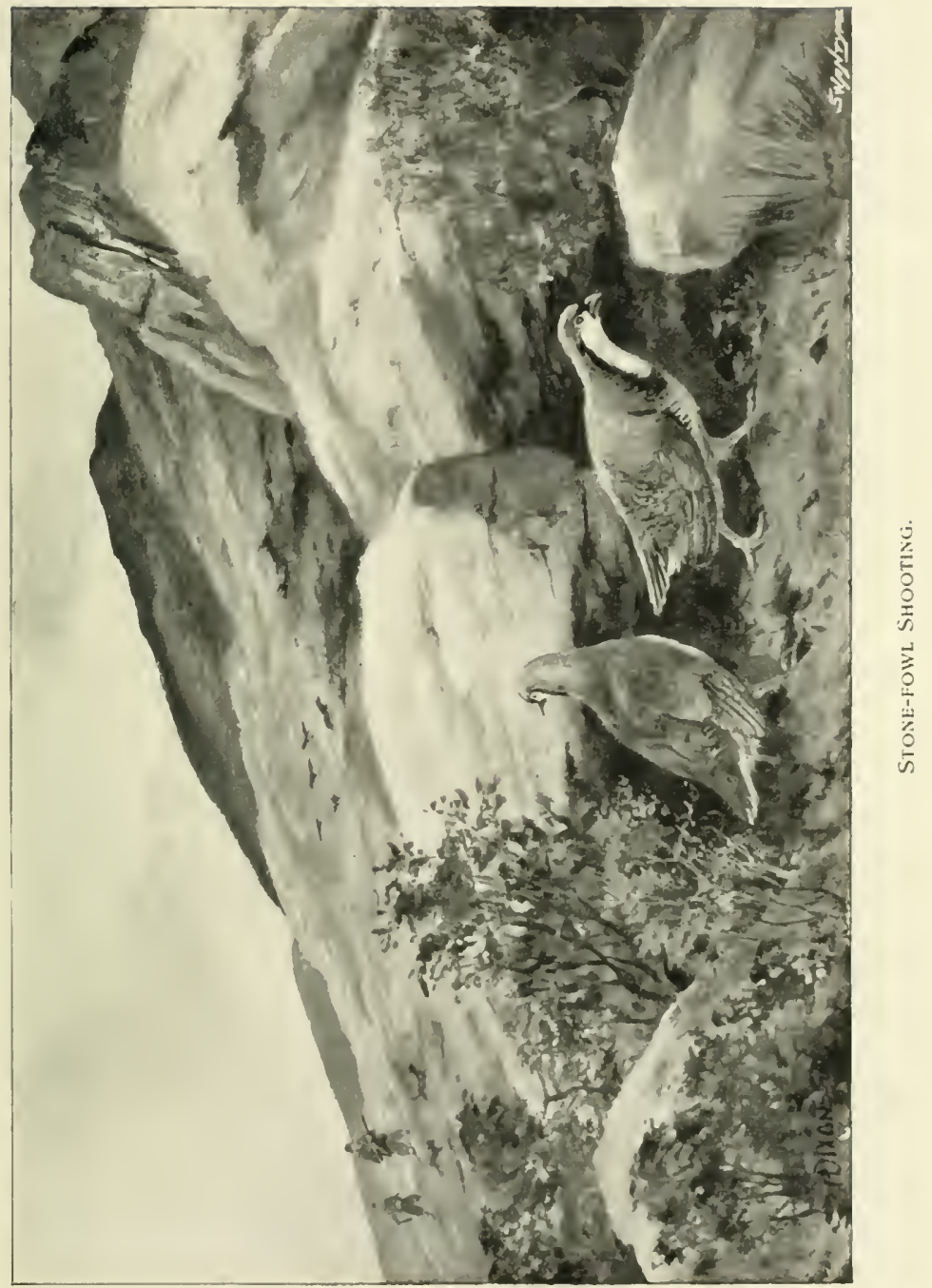



a thorn patch a hundred yards off, but twenty minutes' climb down and up. We walked through it; no result. Then we returned, Ante throwing stones into every bush. Again he got ahead. Whirr! bang! a clear miss to the Morlak. We got another mark, however, but again failed at first to find the bird. Ante again went on alone to an outlying patch, threw in a stone, and missed an easy shot cleau. He then commenced to explain that he hadn't his own gun, and that his shot (No. 5 , for I saw it) was too small for jarebic a, as they call these birds in the local dialect.

The bird had now made for the tremendous precipices above the village of Zakusač, but Ante thought he had a mark, and went off a third time in pursuit. He left his gun, for, as he grimly remarked, he could not use it there, anyway. He clambered about the cliffs for some time without any result, and then I went home, promising to join him next morning. Next day, however, it poured all day.

Although I did not handle one that day, I may as well take this opportunity of describing the bird known by so many different names, * and which, as I do not know of any English name to call it by, I have hitherto spoken of as the stone-

* German, stein-huhn; Italian, coturno or galletto di monte; Illyrian, jarelica; Latin, Perlix græca, according to somo authorities $P$. saxatilis. 
hen, translating the German name, and shall do so in future.

The bird, then, is considerably larger than the partridge, and, like the French variety of that bird, has red legs and a red bill. The prevailing colour is, appropriately enough, stone-grey, with bars under the wings something like those of the sandgrouse. The cock bird has a dark back to the head and neck, and this is edged with a ruff-like border of white feathers, which gives the bird a very handsome appearance. My first experience, as already narrated, gives a good idea of the habits of the bird. It retires at daybreak to high craggy peaks or the roughest rocks on the hillside. This habit constitutes at once a double difficulty to the sportsman, i.e. firstly to find it, and secondly how to dislodge it from its stronghold. It is obvious that only the natives' plan can be followed with any success, as in such ground it is impossible to keep a $d o g$ in view. Then there is the great difficulty of getting the bird to rise, especially when it has been already disturbed. I know of no bird (except, of course, the quail) that would have sat so close as the one concerning which I have already written. Lastly, there is the difficulty of its being a strong, swift flier, as, indeed, the nature of the ground it inhabits necessitates its being. It is useless to attempt long shots at stone-hens, and a right and left is very rarely successful. 
Though the bird is only to be found in small numbers, and those very cunning, in the neighbourhood of towns such as Almissa, there are plenty in the higher hills. Here they have a little immunity from the constant bang-banging that goes on lower down. I have now touched upon the real drawback to Dalmatian shooting. The issue of licences is practically unlimited, and they cost about eighteenpence. This is printed on each: "This licence costs nothing with the exception of the attached stamp-one florin." Nor is this all. I was talking to two natives one day, and complaining how this spoilt the shooting. "Now," said I, "I dare say there are fifty licences granted in this little place." "Yes," was the unexpected reply, "and twice as many people shoot without one." Comment is needless. Ante informed me that he goes every October with two companions for a three days' shoot in the Mossol. Range between Almissa and Spalatro. These hills are four thousand feet high. I asked him what their average bag was, and the answer was eighty to ninety jarebica and fifteen to twenty zecovi (hares). He told me that he knew a district north of Duare where there was "a stone-hen in erery bush," and a couple of guns could easily bag fifty brace in two days. He then went on to say that there were stags in the Biokovo Mountains, which rise to over five thousand feet behind Nakarska, 
but broke down in cross-examination, and finally, when I scratched a roe-buck's head on a flat stone, he confessed that was what he meant. Whether the statement is correct or not I cannot say, but his subsequent one, that there are jackal ${ }^{*}$ and wild cats in both ranges, undoubtedly is.

* The jackal occurs, but very rarely, in Bosnia. Two were killed on the Dalmatian frontier not long ago. 


\section{CHAPTER XIII.}

During the second week of our stay at Almissa (the reason for our extended sojourn there will be given further on) the weather was worse than the first. In fact, it reached a climax on the $3 \mathrm{rd}$ of October, when, after a wet night, it poured all day, and such rain I have rarely seen. Unfortunately the straining canvas drew the centre iron, and the now slack tent utterly failed to keep out the wet. Luckily, we were able to take refuge for the night in one of the tumbledown dormitories of the old seminary. Next morning was fine enough to dry the tent, and then I struck it and got it under cover, and fortunate it was that I did so, for that evening it poured again as hard as ever.

We had been hanging on at Priko in the hope of moving camp to the Falls of Duare by pack transport, and thence back to the sea at Brela. From this village our next camp would probably have been Zostrog. We now renounced this plan, as it involved two consecutive fine days-one to dry the tent sufficiently not to overload a mule, 
and the second for the actual move-and contented ourselves with utilizing one decent day for a long ride to the Falls. We followed the good road its entire length of ten or eleven kilometres, and then struck a rough track. The valley is similar to that which I have already described, with a succession of hills. At last we reached the village of Duare. A kilometre further on is the first fall, and after the heavy rain of the previous days we thought it a fine sight. It is called the "Mala Gubavica," and consists in a single fall of the whole river, which comes down some score of feet into a deep pool. A thundering sound in the distance told us that something better was in prospect, and we hastened on to the "Velika Gubavica," which is five times the height of the lower fall. To complete the romantic beauty of the scene, an old castle on a lofty peak overhangs the whole. This part of the country adjoining the Cettina valley is very bleak and desolate, even for Dalmatia. It is a long day's work to get from Almissa to the Falls and back, especially as the pace is, by the nature of the going, confined to a walk for quite half the way. We had not been in the saddle for months, and fatigue was not the only thing I suffered from that night.

As soon as we had decided to abandon the idea of the Duare camp the weather at once improved, as if to tempt us to a change of plan; but we were 
firm in our resolution to leave the Poglizza, and accordingly on the 6th of October, exactly a fortnight to the hour after our arrival at Almissa, we once more embarked under the now familiar pennant of the Austrian Lloyd Company.

The steamship which conveyed us on this occasion, the Trieste, deserves, I think, more than a passing notice. She is the crack ship of the Austrian Lloyd's Dalmatian Line, and it may be said that she is a bit above her work. When we had sufficiently digested the carved walnut, silk tapestry, and velvet pile of her saloon, we went on a round of inspection, and were perfectly amazed that a ship of this class should be delegated to such work. That a ship making up some forty first-class berths should ever be necessary on a route where the usual passengers consist of two bagmen and a priest was a little hard to believe. The Dalmatian Diet has laid before the Imperial Government a scheme for the erection of first-class hotels and hydropathic establishments all over Dalmatia.* When (and I hope it will be a long

* Sinee these lines have beon written, a company has been brought out for the purpose of building and working good hotels at Cattaro and Ragusa. Certainly good hotels are not to be found in Dalmatia, but if the country is going to be brought "up to date" in this sort of way, it will at once lose the charm it possesses. Roman ruins at Salona, relies of a medixeral republic at Ragusa, and a couple of waterfalls are but poor cards to play against what other countries (e.g. Italy) far moro 
day first) this scheme is carried out, the Trieste will be the right ship in the right place. But, unfortunately, Dalmatia will then be no longer worth visiting.

Fresh surprises were in store for us before our tour of the ship was over. I can only recommend those persons who at any future period may contemplate travelling by the Trieste, not to incur the expense of first-class fares; for surely handpainted saloon and smoking-room, together with yacht-fitted cabins and berths equal to the firstclass, are good enough for anybody, and these things all form part of her second-class accommodation.

Meanwhile, as the Austrian Lloyd Company seem to be striving after something better, may a humble passenger be allowed to suggest that it is not everybody who has been educated to eat half a dozen courses at noon? When we mildly declined dinner at such an abnormal hour we were at once relegated to a very back place in the chief steward's estimation. (By the way, where do the

accessible can show. I cannot too often repeat that Dalmatia is not, per se, an interesting country. The charm of travelling there lies in the fact that one is plunged at once into the last century, and this with absolute security to person and property, as would not be the case in her otherwise more interesting neigbbour Albania. This and other reasons to which $I$ have referred, or shall refer further on, make it the country of all others for the camper-out. 
Austrian Liloyds get their chief stewards, that they should all give one the idea of their having served their time in an imperial household at least?) This we might have better borne had not the autocrat in question absolutely refused to entertain the idea of lunch until the solemn ceremony of soup, fish, etc., etc., had been gone through. Considering the hour at which we had breakfasted, we were pretty well starving before half-past one. However, when it did come, lunch was excellent, though beefsteak, cheddar cheese, and beer is perhaps hardly Dalmatian. Nevertheless, I maintain that a midday table d'hôte on a steamer, which is nothing if not cosmopolitan, is a nuisance. If a man wants sixteen courses at that hour by all means let him have them, but à la carte, and let him not delay the Britisher's humble chop.

Long before lunch, however, we had left a couple of places of call behind us. Firstly, we got back to the eternal island of Brazza again, and the Trieste went through the performance of inducting herself into the tiny but perfectly land-locked harbour of Pučisčie, which is about ten yards wider than the ship in question is long. When we had been solemnly informed that there were exactly the same amount of passengers and goods for embarkation as what we had landed, i.e. nil, we screwed and backed, and puffed and whistled, 
and swore (the skipper did that, though), till at last we were out again and away for the mainland once more, not very many miles south of where we had left it. One of the first villages we passed was another Rogosniča-called di Almissa, to distinguish it-nestling up under the bare crags some mile above the sea. From hence we ran past the famous Vrulja, concerning which the proverb runs, "The bora is born at Fiume, married at Quarnero, and dies at Vrulja." But it dies hard, for the spot is known for its terrific storms, and even this fine, bright morning there was a fresh breeze blowing over the pass. Down the Vrulja winds the high-road from-well, very nearly from all Dalmatia, but lastly from Duare, to Makarska and beyond. Above us now were the rocky masses of the Biokovo, but it would have been hard to believe that those cliffs were as high as any hill in England, but that on this fine, bright morning the fleecy clouds were hanging about halfway up the steep.

By ten we were in Makarska harbour, but it was weary work to tie up so big a ship in so small a port, and it was nearly forty minutes later before we could step ashore. Makarska is, however, a place of no interest (we had got tired of the Illyrian pirate story), so we were not sorry when the reel and bottle performance was completed again and we were once more under way. 
The strip of coast underlying the Biokovo is not unpicturesque, and we had a beantiful morning on which to enjoy it. We noticed with some regret the monastery of Zostrog, close to which fascinating and peaceful spot we had proposed to pitch a camp had not the weather disarranged our plans; and then we bore away from the mainland again. All we saw of Lesina was San Giorgio at the extreme east of the island, and thence our course was a direct one for the mountainous peninsula of Sabioncello. This north-eastern coast of it is bare and uninteresting, but the southern slopes of the hills are said to form an earthly paradise, and are dotted with the villas of Dalmatian skippers, retired from work, to walk solemnly about, I suppose, much as they do in England, with a glass under their arms, and express a strongly qualified opinion that seamanship is a lost art, etc.

Trappano, our port of call on this occasion, is an almost naturally rock-locked harbour, and the peaked rocks have been ingeniously joined by masonry until only an opening little wider than the Trieste is left. Here again we had no little difficulty in getting made fast to the tiny pier some twenty-five feet below our hurricane deck. But this time there was a reason for it, and for a good hour and a half we continued to discharge sacks of flour until we all got heartily sick of the 
performance. Some distraction we had, in the shape of a gang of Bosnian gypsies, who gave an open-air concert on the marina, and, though their voices were not musical, their violin quartets were by no means despicable. They all wore fez or turban, and four at least of them, including two women, would not have attracted the least notice, either in dress or features, in an Indian bazaar. This type of Zingari has disappeared from England for ever, and I fancy the old prejudice against intermarriage with the gorgio must have waned to bring about this result.

We left Trappano some two hours after time, but of course a steamer of this class can easily be driven when necessary, and the mouth of the Narenta River soon came in view. To show, however, how unsuitable a craft of the Trieste class is for such work, I may remark that a small steamer of the ordinary Dalmatian coasting type, which might almost have passed for our steam-pinnace, having called at a couple of ports on the way, came into Trappano harbour as we went out, and yet was only some five minutes after the Lloyd boat in leaving Fort Opus. This advantage she simply gained by being able to run full speed into these little harbours and tie up in two minutes.

The three principal rivers of Dalmatia differ greatly in the characteristics of their mouths. For while the Krka wanders out through a lough 
into a great harbour, and the Cettina tears its way through tremendous cliffs, the Narenta meanders out through nearly a score of miles of fen. Its mouth has more than a suggestion of the Suez Canal, with its little signalman's cottage, stonefaced banks, and ruined labourers' huts. The resemblance ceases when the adjoining marsh is likened to Lake Mareotis, and of course the bare hills enclosing the basin have no parallel at the north end of the canal, at any rate. The marshes seemed to me to promise well for sport, for they swarmed with birds. I saw a buzzard stoop twice at a large wisp of plover, though I could not make out if success crowned his efforts or not.

Soon Fort Opus came in view, with what we took for an old castle overhanging it, and after a more than usually exasperating delay we landed at half-past five, having taken exactly ten hours to complete this journey of fifty-three miles (as the crow flies). It was too late then, of course, to think of pitching camp in a district notorious for fever, so we sought the shelter of the unpretentious but not comfortless hostelry of the place. 


\section{CHAPTER XIV.}

Next morning - a beautiful day, by the way-I proceeded to look out for a place in which to camp. It was obvious that the marshy country by the river was utterly unsuitable for pitching the tent on, so I turned to the higher ground. The difficulty, however, was this, that the Dalmatian hills here, as almost everywhere else, were waterless. Let me try to give the reader an idea of the country. Roughly speaking, Opuzen, to give the place its Slav name, is the centre of a circle of bare hills enclosing an immense swamp. Besides the main and navigable river, there are other streams, which meet close to the village somewhat in the shape of a $\mathbf{Y}$. The lower line represents the steamer channel. At right angles to this runs the little Narenta, trending off to the right. This is not an affluent, but a secondary mouth, and runs into the sea near Oke. A furlong to the south of the little town it is swelled by a deep stream-the left-hand line-which is made up of three or four more which drain the eastern marsh. 
At one point only do the hills approach the town, and this is just across the junction in question. Here a long serrated ridge ends in a detached peak a hundred and ninety feet high, and crowned by fortified buildings. Hearing that these were disused, I climbed up thither, and, entering a tumbledown gateway, finally reached a central platform, if I may so designate an uneven space dotted with buildings. Of these the highest is a bomb-proof keep some thirty feet high, pierced for field artillery and loopholed. The others consist of barrack-rooms, officers' quarters, and offices, all in an advanced stage of decay.

To me, however, the important fact was that this hill afforded ample space for a camp at a height which promised immunity from fever, and a still more important fact was that it was provided with an extensive rain-water cistern in perfect repair.

I at once decided that this place would do, and returned to Fort Opus to arrange for our move. Of course, my first step was to see the proprietor of the site selected, who turned out to be a local tradesman, by name Rado. I found him to be most obliging, as indeed he was throughout our stay, and he not only placed the whole thing at our disposal, but offered to accompany us thither after his dinner, and to bring the keys.

Whilst we were walking up to it he narrated 
the history of the place. The site, he said, was that of a very ancient castle, said, indeed, to be of Roman origin. Twenty years ago only a few fragments of the old walls remained. Then the Russo-Turkish war, with its accompanying troubles in Montenegro and Herzegovina, broke out. The importance of Fort Opus will at once be seen when I say that the Turkish frontier here runs in a semicircle of only some seven miles' radius. The present buildings were hastily run up and garrisoned. After the occupation it was used for some little time both as a military hospital and a depôt, then disused, and finally sold last year to my informant for a little more than a hundred pounds sterling, having cost the government over seven thousand. The very fact shows how much intention the Austrians have of handing back the administered provinces to the Sultan.

From its present appearance, and having regard to the fact that it is not twenty years old, I should say it was built by contract, and was very profitable to the builder. The entrance gate, as I have already said, has fallen in; the roof is off the officers' quarters; one barrack room has entirely disappeared; and even the flagstones at the top of the steps leading to the keep have fallen in. The present owner intends to rebuild it for residential purposes, but had it not passed 
into his hands it would have become a picturesque ruin again in a very few years.

The only part of the whole thing in thorough repair is the keep. There not a pane of glass was broken. When we first pitched our tents we utilized this building for our baggage and stores, and eventually, having swept and garnished it, we lived there entirely. The reason for this will appear hereafter. The room was some thirty feet long by eighteen wide, and was lighted by six field-gun embrasures and eight loopholes. Along each side ran wooden "guard beds" (as we call them in our service), which were useful for stowing odds and ends on. Outside a rough cook-house was in good order, and the sanitary arrangements were perfect. In fact, the only thing that we had to regret in this camp was the sea-bathing, which of course was out of the question, and the riverwater is a rich peat colour. So we had to fall back for the first time on the collapsible indiarubber tub we had brought with us, and which so far we had considered a useless incumbrance.

This, then, was another queer camp-in a border fortress. I may as well explain here that Fort Opus does not, as one might naturally suppose, take its name from this fort, which is known as Gradina. This name, as explained before in reference to Morter, means "ancient city," and is applied to any Roman ruin. 
The views from Gradina are very fine. To the north-east the characteristic Dalmatian hills shut in a plain some five miles across, all marsh, of course, with several streams draining it; whilst further north the steamer channel winds up to Metkovic, behind which a magnificent panorama of the Turkish hills, many of them covered with forest, is spread out. If one turns round, the view is similar, but ends with the open sea framed between the high mountains of the Sabioncello peninsula and the lower island of Lesina. The sunsets here were particularly fine-gorgeous, in fact.

The little town of Fort Opus (or Opuzen) contains nothing of interest, its very church being modern. On the embankment, which serves as a steamer quay, stands an obelisk commemorating the completion of the work which resulted in the permanent establishment of a steamer channel and "the drainage of the marshes." This latter phrase seems to smack rather of gratitude for favours to come, as there are still so many square miles of unprofitable bog, to which the proportion of reclaimed land can only be very trifling. Still, a few walks about the neighbourhood prove that a considerable amount of the former marsh is now vineyard or Indian cornfield, and the reclamation is continually extending. It can never become anything like general until the principal 
canals are all embanked, and fitted with pumping machinery driven either by steam or by windmills. Such an expense the central government is very unlikely to sanction.

The inhabitants of the district, though resembling the other Morlaks of the coast in dress and manners (perhaps I should rather say want of manners), are essentially fenmen. What the mule is to the peasant of the Poglizza the dug-out is to the marsh-dweller of the lower Narenta. I use the term "dug-out," which is so usually misapplied to small rude craft, but the canoes here are really made of separate planks roughly nailed together and tarred. The means of propulsion are single-bladed paddles, used exactly as they are by the Canadian voyageur. Only, as the Morlak, when alone, rarely sits so far astern as the western man, he is obliged frequently to shift his paddle over to the left side, which the Canadian scorns to do. Two people in the same boat invariably paddle on opposite sides here. Apparently they have yet to learn that this greatly increases the difficulty of steering. Men, women, and children seem equally at home in their canoes, and may be seen going to the town with loads of rushes, firewood, or even live stock-these latter, of course, securely bound. For their crops, manure, and so forth, they have boats some twenty-five feet long, exactly the shape of the bowl of a spoon. When 
not in their boats they wade about, even the women carrying leaping-poles. Most of the men take a turn occasionally in the marsh with gun and cast-net, by no means unprofitably.

What a paradise Fort Opus would be to the sportsman who had the time to devote to exploring with a Canadian canoe, especially in winter! Of principal waterways alone there are-the steamer channel, some score of miles in length; the little Narenta, as much more; another stream running up to a lake on the Turkish frontier; another lagoon below Fort Opus; and, in addition, small canals and wide drains in every direction. Much of the marsh can be covered by a man provided with waders, but there are (experto crede) plenty of deep holes where these might be a source of danger.

The Narenta marshes are firstrate shootingground, but not till towards mid-winter. We were too early for really good shooting. Still there were some quail left, and snipe, which with miscellaneous waders and swimmers made up my bag. The best sport is obtained when the bulk of the marsh is frozen hard.

The marshes swarm with snakes, nearly all, however, of the common harmless green variety. I killed one in my first day's walk, whose flat, three-cornered head seemed to me too suspicious for safety, but I fear I wronged it. About the 
very same time the woman who was helping E- killed another, which boldly invaded the cook-house in the fort. Nine was an olive-brown little beast, quite a distinct species from that which I had killed near Almissa.

Two days after our arrival we had a novelty in the shape of a sharp shock of earthquake, which brought the plaster down from the old buildings round the tent. On the day we left there was another. The first shock was followed by a succession of heavy thunderstorms, which reduced the temperature to decidedly cool in the mornings, but later in the day the sun was hot enough.

The natives were unwilling to allow a stranger to go alone in one of their canoes, but finally tho landlord of a wine-shop at the foot of the hill lent me his. His risk certainly was not very great, as these craft cost about twelve shillings. An eager crowd assembled to see the Inglesk start, and was, I fancy, considerably disgusted to see me disappear comfortably and safely round the corner, not to return for some half a dozen hours.

Wandering thus about these fens, even though the gun lie idle for hours in the bottom of the canoe, is pure delight to a lover of nature like myself. There are half a dozen waterways available for such craft, and towards the eastern end of the marshes, towards Neum, in Herzegovina, open out a succession of broads, most of them 
having a water-depth of a couple of feet only. The mud beneath is pretty well fathomless, nevertheless.

The Narenta canoes have one terrible defect, with which I soon became acquainted. There is no backboard of any kind to them, and the effect of a few hours' paddling can better be imagined than described. To the native, who is half a Turk, this want is no drawback, for he can sit cross-legged for hours. I shall not readily forget my first day in one, nor the backache I then acquired. To the last day of my stay I always suffered from this, even when I was not paddling, and half an hour was enough to stiffen my limbs so that I could hardly get out of the boat. To make matters worse this first day, there is a strong tide in the marsh streams-a fact of which I was totally unaware. After making my way against what I took to be a smart current all the morning, I was about to leave the broads to return, when I noticed masses of reed and other floating stuff entering the lakelet from the seaward side at the rate of about four miles an hour. I sadly recognized the meaning of this, and a weary paddle back I had that afternoon. As I have before said, the duck, geese, and woodcock are only winter visitors to these fens. At this time the dabchick were the only birds to be seen in any numbers in the daytime. It was full harvest 
moon at the time, and every evening the local sportsmen were bang-bang-ing away till midnight or later, a proceeding which greatly puzzled me. On inquiry I was told that they were shooting fuligini, which they called with a whistle, and potted at about four yards' range. I could not conceive what the birds in question were, being told that they were black, very fat, and good eating, and also that they sold for fourpence apiece. At last $I$ got to see one, and lo! it was a common bald coot! They must have nearly all been at the seaward end of the marsh, for higher up I did not see one a week. Hawks there were in plenty, large and small. Of the former one kind appeared to spend the day beating the rushes, from which habit I should have put it down as a harrier, were it not that it was as big as a buzzard, or nearly so.

These waters are unmercifully stake-netted * whenever a shower makes them thick enough, but nevertheless I have no doubt that an angler would get plenty of sport here. I saw one native with a canoe half full of fish. The species was unfamiliar to me, but one would have scaled twelve pounds at least.

Cattle and ponies get their living floundering about in the marsh. Of the latter one can only say that they are better than the miserable

* Stake-nets are forbidden within three miles of the sea. 
animals one sees on some of the islands, such as Morter. They sell for about four pounds apiece. It is another reminder that one is on the threshold of the East, that the natives do their thrashing here by driving half a dozen ponies in a circle over the corn. During our stay they were doing this with the sorgum. This is a plant which grows in the marsh. It has a small brown grain like linseed, and is used for live-stock, and also mixed for coarse bread. Ponies and cattle alike swim like ducks, and their owners habitually send them across any streams they may come on in going to or returning from pasture in this way. I have seen quite small calves swim the little Narenta. Here I noticed, for the first time in my life, swimming cattle resting their heads on the buttocks of the beast next before them. This goes far to prove half Herodotus' story, that the red deer in his day used to swim across from the mainland to Cyprus, each resting his head in turn on the quarters of the one in front. If cattle do it, stags, whose head is so much heavier, probably do so too.

In spite of the fact that the whole of the marsh is divided every fifty yards or so by wide ditches of deep mud, the natives tow their larger boats from Fort Opus as far as the broads I have referred to above. It is of course hard work, and very dirty to boot, as may be realized from the 
fact that the tow-man generally takies off his trousers. We are not very particular about our shirts in Dalmatia, anyway, and they generally bear the traces of the vintage well into winter. In fact, I greatly doubt if some of them ever see the washtub at all. The Narenta Morlaks are about as dirty as any Dalmatians, which is saying a good deal. They are also in many ways the representative descendants of the old Narentine pirates. The townspeople, on the other hand, are very civil and obliging, but the town! But that I should be called Rabelaisian, I could give details as to the sanitation (or rather as to its total absence) which, referring to Austria, to a town of a thousand inhabitants, and to the end of the nineteenth century, would appear absolutely incredible. 


\section{CHAPTER XV.}

I HAVE spoken of the old fort at Gradina as being situate on a detached spur of the ridge which divides the seaward marshes from the eastern ones. The term ridge, however, is a misnomer, for the "hill," as they would call it in the Highlands, consists of a series of extinct volcanoes of greater or less extent, similar to the one I have described as existent at Pasman Island. As was the case there, all the centres of the craters are cultivated, and in one is a village-but such a village! The road, if one can possibly give it that name, approaching it consists of rock as rugged but more slippery than that of the surrounding hills. The filthy huts are thatched with reeds brought from the marsh. The very inhabitants seem to belong to that class in the scale of civilization which is below curiosity, and seeks rather to hide itself in its lair at the approach of a stranger. No stronger reminder of the fact that one is only some four or five miles from the Turkish frontier than a sight of this village gives could be required; and it is a proof 
that the Turk is worse outside his own country, for the Herzegovinian villages are far superior to this.

From Gradina a military bridle-road leads to the frontier, and, dividing some two miles out, skirts both marshes, though at a considerable height above them. In addition to this, the hills are scored in every direction by sheep-tracks. These, however, constitute a very doubtful advantage to the sportsman or tourist. It is true the rocks are generally less high where the track runs, but the sheep cover them with a coating of the red soil, on which nails get little hold. Sometimes, also, the track runs for several yards on slab rock, difficult to surmount, but practically impossible to descend in shooting-boots. Occasionally the finishing touch is given by the Morlaks using the path to go to some hill vineyard in a crater above, when their opanke, or raw-hide sandals, put a last polish on the stones, making them look like untouched ivory-very ornamental, but desperately dangerous.

I had already put in a couple of days on the hill, where I was assured there were plenty of stone-hens, without, however, bagging anything more exciting than a few rock-pigeons. Occasionally, too, the dogs would cross the line of a wandering fox and carry it clamorously up to the crags, where, of course, the chase soon ceased in 
the intricate recesses of some of the crevices with which the hills abound.

"You must have a lot of patience," said a Slav to me one day, after he had watched me getting up the tent with two more than usually stupid assistants; but certainly more patience still is necessary for sport in Dalmatia, where the blank days form the rule except at certain times and places, as, for instance, wild-fowling in winter, and the periodical migrations of quail and woodcock. I suppose I have this desirable quality-in sport, at any rate-for I have sat fourteen evenings waiting for a roebuck before now, and often walked a score of miles under an Indian without eren putting rifle to shoulder. At any rate, I had enough to give this particular ground another trial. I took the western military road for some miles, and then turned off into the range. For another hour or more I wandered on without getting a shot.

These hills are-infested, I had almost said, so let it stand-by numerous mountain sheep, whose scent would appear to be strongly "gamey." Three sound thrashings were required before my dogs would give up running them, but nothing would induce them not to draw on the brutes. Time after time I have followed one or the other for a hundred yards or more, and, finger on trigger, watched the dog "drinking in" the scent in the 
expectation of a momentary whirr of wings, only to see the head of some silly-looking old ewe over the rocks at last, or to hear the disappointing tinkle of a bell. "Ware sheep!" was the word then, and the weary climb began again.

I was going along a sheep-track that wound among several knolls, when the rolling of a stone made me turn my head sharply, without thinking, however, of seeing anything more exciting than a sheep that had winded the dogs, or perhaps even a peasant, though I never had met one up there.

Imagine my surprise when my eyes fell on a stag! I felt almost inclined to rub them. Yes, there he was beyond doubt, and, what was more, not much, if at all, over sixty yards off, down wind. He was at gaze when I first saw him, and then he turned and slowly disappeared over the rocks, showing me what my fancy made appear a temptingly fat haunch as he did so. In my experience, after his first look back a deer generally travels best pace.

Now, the gun I had with me in Dalmatia has a left barrel specially bored for ball; but, anyhow, that shot should have been a certainty with a smoothbore. Why, then, did I not take it? Simply for the reason that, to economize weight, I had that morning only put in my bag cartridges for the sport I expected-all No. 5. I could have 
wept to think of the lost opportunity. Only the previous day I had cast a pound of lead into bullets to practise with a view to some big-game shooting in the Administered Provinces, but those were all lying safely in the fort half a dozen miles away.

The stag, then, had disappeared over the knoll. It was the work of a minute to secure the dogs to an olive tree with the strap of my game-bag, and then I ran, as fast as the nature of the ground would let me, to and climbed over the ridge in front of me.

As I had thought, only one valley led through this. I crossed it, and threw myself among some rather prickly bushes on the leeward slope.

I had hardly managed to stop the sobs this burst had provoked (Why does the wind get so thick at middle age?) when I spied my friend coming, as I had expected, right towards me. At first I thought he would take a sheep-track that passed within five yards of me. If he had, I do not think I could have refrained from trying the effect of both barrels in the head at that distance. But he didn't; the one he did take passing at under thirty-five yards, nevertheless.

A very weary, worn-out looking specimen he was, lean and lank withal as a nightmare. One does not expect much from an October stag, but this one was the very typification of the beast. 
Moreover, on the shoulder and side next me, unless my eyes deceived me, he had something like fresh scars, and altogether he looked as if he had been caught in the harem of some bigger brother, and had had more justice than mercy meted out to him. The notorious Mr. Elwes, M.F.H., would have hesitated to put that haunch before a guest; but it wasn't that I wanted-it was his head. Herodias never longed more for that of the Baptist. I could count it now: brow, bay, two on top, and tray one side-nine points in all. What we should call a fair young stag, in fact, though continental sportsmen are so surfeited with fourteen-, sixteen-, and even twentypointers that they will hardly look at a royal, and this stag missed three points to a full head. But then it was the place he was in. A Dalmatian stag! No other sportsman, I believe, can show such a trophy. True, I was right on the Herzegovinian frontier; but I don't think I ever heard of deer so far west in that Turkish province, where, indeed, there are precious few anywhere. Had he come from Bosnia, this gaunt wanderer? Not that I fancy they are by any means so very plentiful even there as they are in some of the real Austrian provinces-Styria, for instance.*

- Since writing these lines, I have ascertained that red deer are so rare in both the Administered Provinces as to be practically non-existent. The exact spot I am writing of is, 
It was not till long afterwards that I thought of all this. At the time I could only watch him slowly, and a little wearily it seemed to me, move down towards the eastern marshes and disappear. And then-well, then I got up, went to release my dogs, and returned home. I have blamed myself since for not at once returning with proper cartridges, but the double journey involved a twelve-mile walk, and who knows how far a stag, moving at that time of day, might have gone on?

Need I say how soon after daybreak next morning I was on the spot again, glass in hand, scanning every corrie and hillside in vain. The following day to that I brought the dogs, and, keeping them close in to myself, tried from its lee edge every possible nook and corner for miles, again in vain. So it went on for nearly a week, till E- - said she never saw me at all from daybreak till dark, but of that stag never a trace did I see. I did once see in a damp hollow what I will swear was the slot of a deer, but, as I opine, that of a hind. If I am right, my stag-why I call him my stag I don't know-was, perhaps, not on a bootless errand after all.

It was whilst engaged in this search that I had the opportunity of observing one of the most however, much nearer to Montenegro than it is to Bosnia (the distance being some fifty miles to the former), but of the game in that kingdom I know nothing. 
amusing encounters in the insect world I think I have ever seen. I was sitting on a rock, resting after the ascent of a more than usually steep bit, when my attention was attracted to the movements of two of the common black scarabcei so invariably to be found on all ground habitually grazed over by sheep. The habits of these insects are no doubt generally known, but perhaps not universally, so I may explain that they lay their eggs in sheep's dung, which they then carefully protect from injury by enclosing it in a ball of earth half as large as a billiard-ball. On this occasion a beetle, no doubt an excellent materfamilias, had so far completed her operations that the earthen sphere was as large as a schoolboy's marble. At this stage of the proceedings she had been attacked by a second, whom I had no hesitation in putting down as an unprincipled highway robber. Whether the bandit's object was simply to steal ball, eggs, and all, or whether she proposed to dissect it and utilize it for her own eggs, I cannot say. At all events, the rightful owner, although the larger of the two, was obviously afraid of her. When they first caught my eye, she was retreating in the most masterly manner, face to the foe, on her fore and middle legs, rolling the precious ball behind her with her two hind ones. This was too much of a handicap on her speed, and the bandit soon overtook her 
and attempted to seize the precious ball, whereupon its owner seized her. A truly Homeric battle ensued. Erect on their hind legs they grappled with each other, and the sound of their mandibles' useless attempts on each other's armour was plainly audible. At last the pirate fairly cross-buttocked the other, and rushed to seize the causa teterrima belli. The owner was too quick for her, however, and both grappled the ball at once, and let it go to resume the contest. The struggle, though no doubt terribly earnest to them, was inexpressibly comical to me, and exactly resembled the "business" of two "knockabouts" on the variety stage. At last the rightful owner left the other sprawling, and, seizing the ball, resumed her retreat as before, only to be again followed and overtaken, when the conflict began again. This happened a score of times, but in the end the gods fought for the right. After what was no doubt a very severe round, the pirate did not at once resume the chase, but remained feeling her antennæ and fore legs carefully for some time. Then she set off again. Meanwhile a third beetle, attracted no doubt by the war-cries of the combatants-which I need hardly say were inaudible to me-joined in the chase. The original beetle had now got a good start, and it was highly ludicrous to see the other two in pursuit, stopping now and then, evidently to listen for the object 
of their search. Unfortunately for the cause of law and order, in her backward march she displaced a small pebble, the sound of which guided the thieves to the spot. With the energy of despair, the anxious mother seized the first comer and hurled her sprawling on to the other, who promptly grappled. Before the fighting stage gave place to the explanatory one,* the retreat was finally and successfully carried out, and never did beetles look more foolish than the discomfited thieves.

When I had finished laughing at them, I resumed my search, but unsuccessfully, and from that hour to this I have never seen, nor even heard of, that stag again.

\section{NOTE TO CHAPTER XV.}

I have left this chapter to stand exactly as it originally appeared (in the Field). As a matter of fact, it was not till long afterwards, and then in rather a curious manner, that the explanation of the matter reached me. The stag was one which had escaped from captivity, many miles from where I saw him. His ultimate fate is a mystery. I may add that, in the present day, the red deer is not found either in Dalmatia, the Herzegovina, Bosnia, or Montenegro.

* "Draw first, and explain afterwards" (Western maxim). 


\section{CHAPTER XVI.}

IT must not be supposed, however, that I devoted the whole of this week to the unavailing search described in the preceding chapter. After the first two or three days, I turned my attention to all-round sport, and particularly to the stone-hens, having gained some experience as to their most likely haunts.

I consider that there is no small-game shooting so thoroughly sporting in its nature as the pursuit of this noble bird, which may well be called the typical sport of Dalmatia, and I venture to think that an experience gained in most European countries, besides Asia and Africa, entitles me to express an opinion. Let me try and bring before my reader a typical shot.

You are descending-or perhaps climbing up, which is easier-an almost precipitous hillside, entirely covered with broken rock, between which here and there a wind-stunted thorn-bush or a little close-cropped herbage appears. Just as you are wondering how you can manage the next bit of rockwork, and whether you must 
sling your gun to enable you to use both hands, or perhaps are reaching down a tentative leg in the hopes of finding secure foothold-whirr! the bird rises.

Lucky for you if you are able to get steady footing enough to shoot. Three sweeps of the wing have carried the bird into the wind, which has apparently been trying to thrash you off the rocks all the morning, and down which he goes at once with a velocity that it would take a driven partridge a quarter of a mile to attain. Nevertheless you hold on to him, as his stagger and the backward twist of his head (sure sign of a sorely wounded bird) show. But the wings are unbroken, and keeping them spread out he sweeps down the hillside, to fall at length-dead, no doubt, but beyond your ken, or the recovering powers of the keenest and best of retrievers, if you had such a one with you.

Meanwhile the dogs are busily bustling round about you. Very probably there are more birds about, perhaps a covey. You are standing at your ease now, ready for anything. Whirr! again. You have the comfortable feeling of "My bird this time," and the gun goes up surely and comfortably. Blessings on the man who invented smokeless powder, and thereby added to the pleasures of the sportsmen, that of being able to see the immediate result of his shot instead 
of having to wait for the smoke to blow away. As you pull the trigger, the swift-flying bird collapses into a heap of tumbled feathers. Even then the wind carries him on some yards ere he falls with a thud, which answers for his plumpness. As a table bird the stone-hen is not to be despised. The flesh is more like that of pheasant than of a partridge in taste. Some people say it has an unpleasant flavour resulting from the taste of a kind of wild sage, whose seed, with insects, forms its principal food. I certainly never noticed anything objectionable about it. E-C's greatest success was obtained by stewing the bird as the French do partridges, but the stock used was made from a hare. Then the bird was really delicious.

I have referred above to smokeless powder. Why is it that Continental sportsmen-in advance of us in many respects in matters relating to shooting-hardly ever use it? Italy is the only country where $I$ found it at all in common use, the variety being our Schultze. Perhaps it is like the prejudice against the 12-bore, which, while the rule with us, is the exception abroad.

I need hardly say that, numerically, great bags are not to be obtained in this district. Half a dozen birds per gun is a good average day; twice that number a very good one. I also bagged a few fine strong hill hares. 
My last day on the hill-and indeed it came near to being my last in more ways than onemay bear relating, especially as it points a moral. My companion on this occasion was the Morlak who supplied us with milk, and who had repeatedly begged mo to go out shooting with him one day. He boasted the possession of a breechloader, but surely a more wonderful specimen of one has rarely been seen. Stock and breech action were those of an army Snider (Turkish he said, and no doubt truthfully), to which some loaal gunmaker had fitted, with brass hoops and similar devices, one of those yard-and-a-half-long barrels, once so common in the East, whose barrel is enlarged at the end to enable the maker to work it into the semblance of a lion's head, from between whose grinning jaws the muzzle protrudes. With this he used 20-bore brass cartridges; but, as the breech was a little too large for them, each one was carefully wrapped round with paper before being pushed in. He always carried it loaded and with the hammer down on the striker. As the trigger-guard was missing, this was perhaps as well. It was also fitted with an iron ramrod, because, as he explained, "the cartridges did not always come out." As a matter of fact, they hardly ever did, and but for the honour and glory of the thing, he would have done much better with a muzzle-loader, for an 
expert loader with one would have been ready much sooner than he ever was. His average of miss-fires was about two in every three shots, but when it did go off he made very creditable shooting with it.

We left Gradina at about eight, and paddled right across the marshes to a hamlet on the highroad which leads from Metkovic to Neum, in Turkey. The marshes were alive with waders that morning, and we had not gone far before Jusic shoved the canoe ashore and begged me to "shoot the snipe." Now, I never can see a snipe on the ground, so, after some fruitless attempts on his part to point it out, the long barrel was pushed over my shoulder, and scolopax lay kicking in the mud. At the shot dozens of others flew off, but I had no small-shot cartridges with me. Presently he tried to point out another not three yards off, but again unsuccessfully, and the bird was off before he could shoot. There were literally any quantity about just there, and also plover, of which last I annexed three out of divers flocks that swept over us. I think it must have taken us two hours to paddle across, and then we took to the hills. As we had neither of us any exact idea of where the birds were likely to be, we beat up two sides of a steep glen, and before long I heard their familiar call, a sort of choking whistle. The Morlak had got 
rather in front, and was circling round the valley towards me. Presently I heard his piece to my left front. At the sound a single bird rose to my right and swept past me, only to fall with a plump among the rocks, and almost on the back of a fine fox, whom I had not before noticed, and who was coming right towards me. He was out of sight in an instant among the stones, or I should have given him the contents of the other barrel. The dachshunds dashed forward, and while the red dog retrieved my bird, old "Waldmann" took up the line of the fox at once, and ran him full cry nearly down to the marshes and back again, till, just as we began to hope for a shot, he got to ground. As I had guessed, it was Jusić who had disturbed Reynard and given him a barrel, but, according to his own statement, he was too far away.

We had now got to the top of the hill, and as it was nearly as high as any ground about, we made a cache of our lunch and the birds we had killed so far, and went on towards the frontier. It was a long time before we did anything, for we had failed to find the covey I had heard. At last, working along a rocky ridge a mile further, I heard stone-hens calling, and signalled to the Morlak. We hurried on,*

* I do not conceal my beginner's mistakes. Hurry is the one thing fatal in stone-hen shooting-as, indeed, it is in all shooting. 
and a covey got up wild in front of Jusić. Directly afterwards I put up two birds and bagged one, and this I repeated fifty yards further on. Presently we got to where the ridge ended. I had calculated the birds would drop here rather than face the high scirocco wind round the corner, and my idea was well founded. The birds rose in quick succession, and we had laid the foundations of a good bag before we had done with them. We had marked two or three on to the hill beyond, so we crossed the valley between, but failed to find the birds we were looking for. Probably they had sat still. A stone-hen generally runs uphill after he has been moved, and thus makes it easy for dogs to pick up the scent. When he sits still among high rocks it is almost impossible for small dogs to hit him off, and unless you almost step on him he will not rise. "Waldmann" got on a line here, whether of fox or of hare I cannot say, and ran it back a mile or more. He thus lost us, and I saw no more of him till our sport was finished. I expected to find him down by the canoe, but when at last we got back to where we had hidden the lunch, there he was waiting for us. If this is not reason I do not know what is: "They left some things among the rocks here, ergo they will return here."

Meanwhile we were trying on. The hillside 
was bad going. I was just thinking so, when some juniper bushes forced me to pass along the very edge of a cliff. I had taken hold of a pointed rock, intending to pass outside it, when the volcanic stuff broke off in my hand, and down I went backwards. I suppose, from the score of cuts all over my hands, that I broke my fall a little by clutching at the rocks as I went down. I remember trying to save my gun, and in this I was fairly successful. Now that I know how seriously I was knocked about, I ann surprised to remember how quickly I staggered to my feet again at the bottom of the fifteen or seventeen feet cliff. I felt very sick and queer, but I soon realized that no bones were broken.* The most painful injury was a bruised cut, through coat and breeches, on the right hip, and, in addition to this and the cuts on my hands, both knees were badly knocked about, my elbow cut and bruised, and my ankle twisted. Altogether it was a "useful" tumble. Presently I caught sight of the Morlak, signalled him, and limped back to the canoe.

The moral of my exploit is twofold-firstly, not to trust to these volcanic rocks, either as foot or hand hold, especially when they are sharp, thin points. I ought to have been on my guard, as

* As a matter of fact, my left knee-cap was split, but this I did not know for a long time. 
they had played me the same trick before, though not with the same serious consequences. Secondly, it points to the necessity for caution, generally speaking, among these hills, as an accident, especially to any one shooting alone, as I usually did, may easily be attended with serious consequences. I can only look upon my escape, after falling from such a height, and with a loaded and cocked gun, as most providential. 


\section{CHAPTER XVII.}

That the frontier fort would be our last camp in 1894 was something which I had not by any means anticipated, but so it proved. As far as the weather was concerned, we could have easily remained in camp much longer, but two unforeseen occurrences rendered this impossible. The first was an accident to the tent, which happened in this manner.

In consequence of the smake nuisance, we had taken to sleeping in the old barrack-room. Not that the brutes were in any way dangerous, nearly all of them being the common green variety, but their continual presence acted upon E-'s nerves. It must be admitted that they are creepy things, and make the idea of sleeping on the floor unpleasant. I have already mentioned two killed the first day. A day or two afterwards E- saw another lower itself from the sill of one of the embrasures on to the window-sill. When she valiantly opened it, it slid over the edge and disappeared. After this we had peace 
for some days. One morning when I was absent a small common snake tried to come up the steps, and after a combat, which from the description furnished me must have been little less than Homeric, was pluckily slain by our chatelaine. On my return I took a stick and walked round the fort, killing four more in a quarter of an hour, but even this did not prevent two others, one of which was ensconced in a loophole, from sharing a like fate the next day.

For this reason the tent was temporarily abandoned. Now, tents, like sweethearts, must not be neglected. It so happened that at this time there was a very high scirocco wind, which lasted for nearly a week. This wind, as far as frequent occurrence goes, here replaces the bora of Northern Dalmatia, but, from its hot, damp, and relaxing character, is to my mind infinitely more objectionable. It always made me feel absolutely good for nothing, and I shall probably make its nature clear to a good many of my reader's when I say it was exactly like a Gibraltar "levanter." Now, if we had been living in the tent, the pegs, etc., would naturally have been overhauled daily. As it was, the centre rope was slack and the pegs loosened, with the result that when I got up one morning I found the weather side of the tent more concave than convex. I guessed at once what had happened: two of the 
ribs had been bent back and snapped off. This finished our camping, for, owing to the great strain put on these ribs, I had no confidence in any local wood to replace the stout English ash. When the tent was dry I struck it, and the Union Jack waved no more that year in Dalmatia.

I certainly should have contrived in some way to patch up the damage but for a much more. serious loss, of which this accident was the indirect. cause. It happened thus. After the tent had. been taken in, I left the ground-sheet out till the weather improved, and then spread it out to. dry. Next morning it was gone. Search, not unnaturally, proved fruitless, for a piece of tarpaulin thirteen feet in diameter is not easily mislaid. My next step was to invoke the aid of the gendarmerie, who promptily arrived on the. scene. So did Mr. Rado, the proprietor of the fort, highly indignant that anybody should have had the audacity to steal on his ground. I am bound to say that they did their utmost, the Wachtmeister officially, and the other privately. Both, I believed, cross-examined every dweller in Gradina, and the aid of the Syndic of Opuzen was invoked. Nay, it did not end with the temporal authorities, for after mass next Sunday the priest, to whom I had said nothing at all, announced the loss from the pulpit, and, pointing out the disgrace to the place arising from strangers 
being so treated, begged the thief at least to stealthily replace the missing article by night. But he didn't; nor did the police get any clue; and we finally left the place without it. This, of course, put an end to any further prospects of camping out.

I cannot, honestly say I altogether regretted the fact. Although Dalmatia is a climate where one can well camp out till the end of November, still one should have a tent with a double roof. I had felt from the first that this was a great omission in our outfit, and the misfortune with the camp-beds was even worse. The fact is that the trip was well planned enough, but our intentions only serred as paving-stones for the realms below. I had proposed to start fairly early in June, and the lost two months were not to be made up. The fault was nobody's; the British public must be the first consideration of those who live by the pen, and if the proofs of "Gun, Rifle, and Hound" could not be corrected by June, the writer thereof must possess his soul in patience throughout July.*

We might, of course, have gone on and visited the remainder of Dalmatia by utilizing the hotels

* By a singular coincidence, the author received this sheet for revision at a time when he was again experiencing the difficulty of combining the regular correction of proofs with an out-of-the-way expedition. 
at Ragusa and Cattaro. This I was loth to do, as I hoped to be able to carry out my campingtour in the spring. So we decided finally to winter at Mostar, where I had letters of introduction, and see something of the sport to be found in the Administered Provinces.

We remained a week longer at Fort Opus, waiting to receive warmer clothing, for which we had written, and boots. The former was a necessity, as, though the town of Mostar is only a hundred feet higher than the old fort at Gradina, the climate is very different. As to the latter, one needs to go to Dalmatia to see how boots go there. The rocks cut them to pieces in no time, unless they are of the very best of leather. I have previously had occasion to recommend the Wye boots made by Hattons of Hereford. Well, these were the only ones which stood the work here at all, and right glad was I to receive a fresh supply before leaving Dalmatia.

All the steamers which leave Fort Opus for Metkovic do so in the afternoon, and only on Tuesday is there any true connection with the train service beyond. Now, as it was this very Tuesday boat which brought the things for which we were waiting, we were naturally unable to go by it, and consequently were obliged to spend a night at Metković.

We left Fort Opus on the Wednesday evening 
by Rismondo steamer. Our voyage (of half an hour) was performed in the dark, but in any case I imagine that I have already given the reader a pretty good idea of the lower Narenta and its marshes. The only building-other than village huts-which we passed is a Martello tower, probably modern; at any rate, modernized to the latest date at which such defences were of any use, and now transformed into a windmill.

Metkovic is probably the most uninteresting place in Dalmatia. Only it seemed odd to us to find ourselves the next morning (All Saints' Day) in a land of picturesque costume again, whereas at Fort Opus we had had practically nothing of the sort. The streets were gay with peasants come in for the festa. The women here wear a quaint white costume, often handsomely embroidered. By the men the fez is almost universally worn - the first symptom of the vicinity of Turkey.

That morning we met an old friend again in the shape of the bora, which blew both hard and keenly, and made the crossing of the river decidedly unpleasant. Although Metkovic, as the terminus of the Bosnian and Herzegovinian State Railway, has become a place of some importance, it has not yet got a bridge to connect it with its railway station on the northern bank of the Narenta. But what is still more extraordinary 
is, that it has, and has had for nearly two years, three-fifths of a wooden military trestle bridge! It is not ornamental, but if somebody were to take it into his head that it might as well be completed, it certainly would be an improvement on the ferry-boat.*

It seemed strange to us to enter a railway station for the first time for nearly a quarter of a year. A very pretty little station it is, too, much of it covered with Virginia creeper, then in its most gorgeous autumn colouring. Adjoining it is a pretty garden, planted with young trees, which will some day be a delightful place of resort for the good people of Metković, for I suppose they will have their bridge completed by the time the trees are a good size. The railway is a narrow-gange one, little over two feet, but the little carriages are comfortable enough.

Our departure was attended by the usual Continental ceremony. When the shouting and whistling were over, the guard performed the customary solo on the penny trumpet; we moved off, and in a few minutes our Dalmatian trip was at an end. The Turkish frontier is passed imperceptibly. Not as much as the usual painted post marks it out-at least, we saw nothing of the kind. The first station on the line is Gabela, * Vide Part III. 
and before reaching it one sees the ruins of the old Venetian frontier post on a rock high above it. Old towers dot the marsh, too, in places; but we had nearly done with the fen country. At Čapljina the sunny parts of the houses were festooned with Turkish tobacco, now nearly ready for carrying to the government depôts. The Narenta, which runs beside the railway-line all the way to Konjica, now enters a gorge which reminded me greatly of the Cettina valley, but the hills are lower. At its mouth lies Pocitelj, a curious old-world fortified town. Here we saw the first mosque; and as a further reminder that we were in the land of the Crescent, two or three of those shapeless bundles, which we are assured contain Turkish women, were waiting on the platform of the station, which, by the way, is like that of Metkovic, only connected with the town by a ferry. At Dretelj, as the station is called, we waited a good quarter of an hour, as indeed we did nearly everywhere, though it seemed most unnecessary. As the distance from Metkovic to Mostar is only twenty-six miles, one fails to see why the journey should take two hours. But if we found the line exasperating, what must it be to through passengers, say from Spalatro? As I have already explained, they are pretty sure to have to spend one night at Metković. That they must spend another at Mostar is certain. Twice 
a week one can get off with a dozen hours there, but generally it is eighteen. The eighty odd miles on to Sarajevo take eight or nine hours more, and there another night has to be passed. The down journey is quite as bad. I can see no reason why the train should not leave Metkovic after the steamers are all in, say at seven p.m., and run right through in time to catch the morning train at Sarajevo.

At the upper end of the Pocitelj gorge the Narenta, now reduced to the proportions of a mountain torrent-and, by the way, an excellent trouting stream-falls over a rock barrier, which, though only some five or six feet high, must be a hundred yards long. The place is called Buna. Here, too, the Baracrusa runs into it under an old Roman bridge of thirteen arches. At the time of the Turkish conquest of the Herzegovina, many noble families emigrated from this place to Zengg, in Croatia. Their descendants still live there, and still call themselves "Bunjevći."

Passing a wide plain, the line reaches a point whence a glimpse of the Herzegovinian capital with its old Turkish bridge and the minarets of its thirty-three mosques can be obtained; and then runs through a purely Turlish quarter, where the unveiled women rush into their houses with well-affected surprise as we glide past, and we are in Mostar. 


\section{CHAPTER XVIII.}

As one of my principal objects in writing this book has been to induce others to go and do likewise, and to avail themselves of the opportunity presented by a country probably more suitable to such trips, by reason of its climate, inexpensiveness, natural beauties, and perfect security, than any other in Europe, and in which alone shooting, fishing, boating, bathing, and camping can be equally enjoyed, I propose to conclude this part with a chapter which shall contain such information useful to such imitators of our idea as cannot be directly ascertained from the preceding pages.

Leaving the question of camp outfit till later on, I will only remark here that this is an expense that may be dispensed with, if desired. Rough accommodation can be obtained at most villages, either in the house of the priest or in that of the capo luogo, or village headman; and though this is not a plan I should prefer, it certainly saves a large item in the total cost, especially where a short trip (say a month) is contemplated. 
The expense of the journey to Trieste can bo readily ascertained at any London tourist office. From Trieste to Zara the fare is about $7 s$. $6 \mathrm{~d}$. first class. The local steamer fares are low, about a penny a mile being the average first-class charge. As for sailing-boats, there is of course no fixed tariff. A large fishing-boat, with two men, who will assist to strike and re-pitch the tent, should cost about a florin (1s. 8d.) for every four miles; that is to say, they should go twenty miles for five florins. Though this may seem a high price for so cheap a country, it must be remembered that a foul wind may cause them to lose two days' work, or even more.

A woman or lad to wash up, scour cookingutensils, fetch water, and run errands is liberally paid with twenty-five kreutzer (here called soldi, by the way), or $5 d$. a day. This would be for about an hour's work in the morning, and as much again in the evening. In each of the above cases a fixed bargain beforehand is absolutely necessarya remark which applies to most transactions with the natives.

Living is, as I have before said, remarkably cheap, with the exception, perhaps, of white bread, which, however, cannot be obtained in the smaller places.

The following table was compiled by my wife in Northern Dalmatia, and may be taken as a guide 
for the whole country, though there are places, e.g. Fort Opus, where prices rule higher:-

\begin{tabular}{|c|c|c|c|c|}
\hline Beef & $\ldots$ & $\ldots$ & $\begin{array}{l}\text { Kreutzer. } \\
38 \text { to } 48\end{array}$ & $\begin{array}{l}\text { Remarks. } \\
\text { Only to be had in large towns. }\end{array}$ \\
\hline MIutton & $\ldots$ & $\ldots$ & 28 to 31 & \\
\hline Lamb & $\ldots$ & $\ldots$ & 33 to 36 & \\
\hline White Bre & & $\ldots$ & 16 & \\
\hline Biscuit ( $\theta$ & ch) & $\ldots$ & 2 & $\begin{array}{l}\text { Dry circular rolls, almost uni- } \\
\text { versally used in the islands, } \\
\text { and not unpalatable. }\end{array}$ \\
\hline Fish & $\ldots$ & & om 12 & According to quality. \\
\hline Lard & $\ldots$ & $\cdots$ & 80 & \\
\hline Butter & $\ldots$ & $\ldots$ & 100 & Rare and bad. \\
\hline Milk (per & litre) & $\ldots$ & 16 to 22 & Often very hard to get. \\
\hline Cheese & $\ldots$ & $\ldots$ & 50 to 100 & \\
\hline Wine (per & litre) & $\ldots$ & 12 to 16 & Servants' wine from 8. \\
\hline Grapes & $\ldots$ & $\ldots$ & 4 to 8 & \\
\hline Figs & $\ldots$ & $\ldots$ & 2 to 4 & \\
\hline Potatoes & $\ldots$ & $\ldots$ & 5 to 6 & \\
\hline Tomatoes & $\ldots$ & $\ldots$ & 8 & \\
\hline Large fow & ls (each & & 34 to 50 & \\
\hline Eggs (per & dozen) & & 18 to 30 & \\
\hline Olive oil & per litre & & 24 & \\
\hline
\end{tabular}

Where not otherwise mentioned, these prices are for a kilogramme (about two pounds and a quarter). For rough calculation, five kreutzer may be reckoned as a penny. English housewives may be interested by the following list of average prices :-

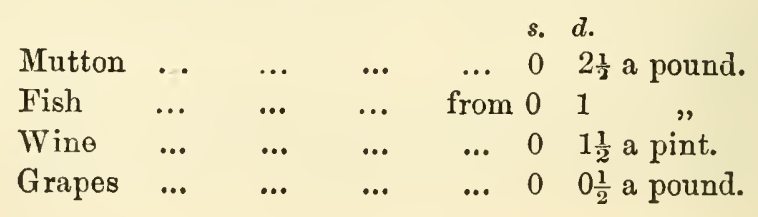




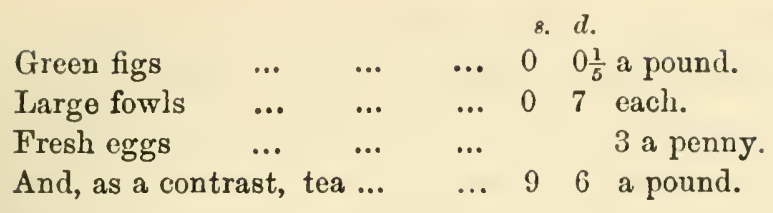

This last article should be brought from England, and duty paid at the Austrian frontier.

I calculated that the expense of our first two months' trip, exclusive, of course, of stay in towns, but including boats, etc., averaged $\$ 1$ a week for two persons.

The Austrian coinage, being in a transition state, is a little puzzling at first. A simple rule, however, is the following: All money bearing the imperial eagle (or Hungarian crown), and not a head, has only half its face value in kreutzers. The coins in question are the new coinage, and are made in 20 and 10 (nickel) and 2 (copper) pieces. Their value thus is 10, 5, and 1 kreutzers respectively. Some of the islanders still reckon by the old Venetian money, which is simply maddening; and in other districts they calculate by the sechser, or 10-kreutzer piece.

We now come to the question of camp equipment, and this of course is a heavy item, of which the principal expense is the tent. Ours cost about $£ 13$, and the experience of the trip only goes to prove that the opinion I have so often previously expressed, that there is no tent to touch Captain 
Newburgh Stewart's patent, was perfectly well founded. Far be it from me to say, however, that there are not other tents which will fulfil all the requirements of such a trip; and $I$ do not see how the intending tourist can do better than put himself in the hands of Messrs. Piggott Bros., of Bishopsgate, faciles principes of English tentmakers, and name the expense which it is proposed to incur. They supply tents from $£ 25 s$. upwards (only a sleeping-shelter, of course, this); and the necessary items of canteen, camp-furniture, etc., may be equally well selected at their establishment. I may add that tents in good order can be resold to the makers at a fair price when done with.

In our first summer's camping we felt the want of a camp-stove greatly. I know of no English stove that is any good, but during the winter I obtained one from an Illinois firm, of which more anon.

If expense were no great object, the pleasure of a Dalmatian trip could be greatly enhanced by having one's own boat. A whaler decked forward, and carrying a lug or lateen sail, could easily be obtained in Trieste, and resold on return. Still, it must be recollected that the mere possession of a boat ties one entirely to the coast and islands, whereas a well-arranged tent and camp-gear will go anywhere.
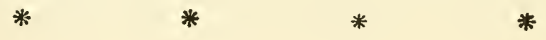

* 
Language is rather a difficulty. I found my (very indifferent) Italian most useful. The Austrian navy is almost entirely recruited in Dalmatia and Istria, and the men who have served in the "Marine" all speak some Italian. The higher officials speak German, and the gendarmerie are supposed to, but in reality few do. An Englishman speaking Serbo-Croatish is, I should imagine, rather a rarity. Failing a little Italian, I should feel inclined to recommend the engagement of a handy man as camp servant, who could act as interpreter, in Trieste.

Clothing both for men and ladies must, of course, be adapted to the season. For the Dalmatian summer, and on such a trip, there can be no better wear for both sexes than the drab drill used by the Indian Army, and there known as khaki. A couple of suits of this-one with knickerbockers*-a thicker suit, and a mackintosh, are a sufficient outfit for a man for such a trip. Of course flannel is necessary underwear, and [N.B.] especially at night, in camp.

I have spoken elsewhere of the difficulty of

* I personally wore the Austrian mountaineer's dress-short breeches, with knitted leggings from the ankle to just under tho knee, which is left bare, and this I found a most excellent kit. The superiority in eomfort and freedom over breeches or knickerbockers can only be appreciated after a trial of both. 
getting paper money cashed at some of the Dalmatian towns. Unfortunately, I was not aware, before I came, of that excellent arrangement the Austrian sparcasse, or Post-Office SavingsBank. If you put your money in this at Trieste, you can draw out what you require at any postoffice without giving previous notice, on production of passport; and this is the plan that the natives resort to when travelling. This is a "wrinkle" which applies to other travellers than to the camper, and, I may add, to every part of Austria, but not to the occupied provinces of Bosnia and Herzegovina.

As I have mentioned passports, I may as well say that such a document is absolutely necessary in journeys of this kind. It must be produced to get a permit to carry arms, and also greatly facilitates getting one's letters at the various post-offices. 


\section{PART II.-THE HERZEGOVINA. 1894-5-6.}

\section{CHAPTER XIX.}

IT seems strange to go to a Turkish town-and surely Mostar is that, for the Mohammedan population outnumbers all the others-to re-enter civilization, but nevertheless this is exactly what we did do. Only a peremptory demand for passports at the station exit reminded us that wo were under a military occupation, and then we entered the hotel omnibus and drove off.

Surely the wildest romancer never imagined such a strange medley as the larger towns in the Administered Provinces present. The hotels are Viennese in style, if not quite in comfort; the principal shops almost equal to those in our English country towns. The streets are clean and well kept, and the sanitation excellent. And then, at every corner there is a mosque, a Mohammedan burying-ground, or (more homelike still to the Anglo-Indian) a genuine Eastern bazaar. The medley of nations and costumes is equally 
strange. The Viennese gigerl eyes with interest the shapeless Turkish females; red-breeched Bosnian troopers salute trim Hungarian jäger officers; and thoroughly German Müdchen trip along to school, escorted by baggy-trousered Serb waiting-women. Officially we all speak German in Mostar, but a babel of languages, of which about the only one one does not hear is Turkish, reaches the ear on every side. Every one of the provinces of polyglot Austria is well represented in this little town.

Let us turn to the place itself. The situation is picturesque, and would be more so but for the barrenness of the hills which surround it. The Narenta runs between and over black rocks, and below the town the hills come so near to the river as almost to form a gorge. Above this the land to the north-west broadens out into a smiling plain, covered with maize-fields and vineyards, but also enclosed by bare hills. On the left bank of the river lies the town, straggling out from a cluster of buildings to terminate in a permanent military camp at each end. The low, stone-roofed Turkish houses and minarets contrast oddly with the huge and hideous red-tiled buildings run up for residential and official purposes since the Occupation. The suburbs on the other bank are mostly native at present, and their numerous gardens make them pleasant to the eye. 
Just at the mouth of the above-mentioned gorge comes the "lion" of Mostar-the famous Starimost, or old bridge. Long supposed to be Roman, it is now admitted to be of Turkish origin. From between two black cliffs a pointed arch fifty-five feet high crosses some ninety feet at a single span. On the northern shore is a once defensible gateway. From a laudable desire to preserve this interesting relic, it has been closed to wheeled traffic, which must cross by the new Francis Joseph Bridge. It is, however, probably strong enough-at least, field batteries fully horsed crossed it in 1878. A similar but much smaller and modern arch crosses a confluent stream just below the great bridge.

This stream, by name Česma, is in itself one of the prettiest things about Mostar. Not only does it end its existence with a fall of considerable size (especially after rain) into the bed of the Narenta, but throughout its course it is a charming, babbling trout-strearn, with picturesque milldams. Towards its source the valley it waters shrinks to a rocky glen, winding at one spot round a weird mass of rocks, which might well pass by moonlight for a ruined castle. Its source is curious. It is what is known as a cave-stream (Grottenfluss). The whole body of water quells out in one mass at the foot of a precipitons cliff. It is, when new-born, large enough to drive a 
mill-wheel, and actually does so a furlong lower down. These cave-streams are not uncommon in these parts, the Ombla near Ragusa, which is navigable to its source, being the largest and probably the best-known example. Nearer Mostar than this is an instance of the opposite processthe river Trebinčica, after flowing for some fifty miles, suddenly vanishes into an awsome cavern, never to be seen again of mortal man.

The origin of the particular stream of which I write is no doubt the infiltration of the waters of the great Mostarsko Blato, or Mostar Marsh, from which a mountain separates it. This marsh, although quite a lake in winter, is quite dry in summer, ${ }^{*}$ but no doubt the water is contained in subterranean reservoirs. The spring has now been surrounded with a Lustgarten quite in the German style, with a restaurant, etc., which seems rather a pity. The water-supply of Mostar has long been obtained from this source, but of late years elaborate filtering arrangements and new pipes have been fitted up, forming one of the sights which are always shown to the visitor to Mostar. The pressure obtainable is nevertheless so low that no water is laid on to the houses, but must be fetched by hand from street taps.

There are several of these cave-streams in the immediate vicinity of Mostar. The largest and

* Ordinary summers. This was not the case in 1895 . 
most picturesque is that of the Buna at Blagaj. This is another place to which the visitor is always taken. Besides the romantic cavern in question, Blagaj contains nothing of interest; but not far from it is the fine old castle of Stepansgrad, round which vultures may always be seen sailing. Favoured visitors to Mostar are genorally invited to have a day at these, the method being sitting up over a carcase. This is a "sport" which will appeal to few, certainly not to the Anglo-Indian. Besides, the birds, which at the Occupation were as tame as elsewhere in the East, have learnt the lesson of shyness, and I think the only person I remember having any success was the young Archduke Ladislas, since accidentally killed out shooting.

Buna, before mentioned, is also worth a visit, though Omar Pacha's gardens there are in a very different condition from what they were in his time; and this, I think, exhausts the list of Mostar sights. The mosques are absolutely without interest, unless, indeed, to those who never saw one.

For the benefit of sportsmen, I may add that the Česma and Jansenica streams are the best places about for woodcock, especially the former. Duck are to bo found on the Buna.

If Mostar is poorly provided with objects of antiquarian or picturesque interest, there are, however, plenty of modern and utilitarian establish- 
ments well worth a visit. Such are the various schools, and above all the splendid establishments for the encouragement of viticulture, horticulture, forestry, and stock-breeding. The various schemes for the improvement of the land in these two provinces each form an interesting study to the specialist, but are beyond the scope of a book of this kind. Some, however, are of general interest, and of these I may speak.

One of these, perhaps more for the benefit of the finances than the people, is the great Tobacco Depot. The visitor is conducted, step by step. one might almost say, from the sowing to the completion of the "weed."

At two doors stand scales for the weighing of the raw material. The quaintly dressed peasant unloads his pack-ponies at the door. Each bale is then weighed separately, and a sample is examined by an expert, who classifies the lot as of first, second, or third quality. Another official hands the cultivator a receipt, and the bale is carried off to the warehouses at the back. Thence in course of time it finds its way to a room where a score of women, also experts, separate every leaf and throw them into boxes marked "fine," "finest," and so on. These are next taken to the machine destined to cut up only that quality of tobacco, but of course only after they are fully dried. The tobacco is then ready for packing. Much of it is made 
up into cigarettes by girls. The process is not quite that with which we are familiar, for they are supplied with completed cigarette-papers, into which cylinders the tobacco is pushed. Another girl cuts off the loose ends, and the cigarette is ready. They are then packed in boxes. As a rule Herzegovinian cigarettes are made with mouthpieces. No cigars are made here.

The tobacco, which is to be sold as such, is also put up in packets by women. The very finest ( $f(\ddot{r} r$ ) is combed out by hand, and the threads, which are all of equal length, are packed in tin boxes. This quality, of course, is very expensive.

The fault, to an English smoker, of these tobaccos is that they are so very dry. Of course one has the satisfaction of knowing that one is not buying water at the price of tobacco; but some damping process is necessary before the government product can be smoked in a pipe. Even then it cannot be called satisfactory, as it is all too finely cut.

The prices paid to the cultivator are, of course, a great deal lower than those at which the tobacco is afterwards sold. Allowing for the heavy expenses of the factory, and of the fiscal supervision of the fields, roads, and frontiers, the profit must be enormous. This of course leads to smuggling, and excellent contraband tobacco can be readily bought at much less than half the 
price charged by the government. Besides, this tobacco has not the fault of being so terribly dry, and it is not finely cut. In spite, however, of the government's taking a lion's share of the profits, the cultivation of tobacco is an enormous source of wealth to the peasantry. In the district (Bezirk) of Mostar alone, the payments made them by government annually on this account are equal to ten florins (16s. $8 d$.) per head of the entire population. Each cultivator is allowed to retain $16 \mathrm{lbs}$. of inferior tobacco every year for the use of each adult male smoking member of his family-not to exceed 48lbs. in all. This he is strictly forbidden to sell; but, as I have already said, the thing is not unknown, all the same.

The government establishment which interested me most at Mostar was the haras. On expressing a wish to describe it to English readers (which I did in the Live Stock Journal, February 15, 1895), every assistance was given me by those concerned. Before going into the matter, I may perhaps be allowed to say a few words as to the Herzegovina and its horse-breeding capacities. Consisting, as so much of it does, of barren and rocky mountains, it is obvious that the country is in no position to produce a large breed of horse. Few, indeed, of the local animals come up to polo standard, even in height, and as a dozen years ago there was hardly a road in the country, their 
usual destination-as, indeed, it mostly is nowwas pack-transport. As the winters are hard enough on the mountains, and the keep scarce, it is obvious the weakly foal has little chance, even if he did not, as he generally does, fall a victim to the wolves, which do great damage in some districts. The result of the local and climatic conditions, combined with the utter want of any supervision in Turkish days, has been to produce a short-necked, straight-shouldered, cow-hocked pony, little, if at all, over thirteen hands, but possessing great hardiness and endurance.

Till the year 1885 no attempt at any improvement would seem to have been made. The reproduction of the race in general was provided for by letting the colts run with their dams for three or four years,* and the Herzegovinian pony bid fair to descend to the level of that of the Dalmatian Islands, the lowest type of horseflesh with which I am acquainted. It was obviously desirable that such a state of things should be put an end to, but little could be expected from the peasantry, whose pig-headed obstinacy, clinging as it does to the old and bad methods, constitutes the greatest difficulty to the Austrian administrators. Still, it was decided that the

* Oceasionally, especially near Mostar, the Turkish cavalry horses wero allowed to serve, and the breed was thereby much improved. 
attempt should be made, and that attempt has been so far successful that it is a pity funds are not available to provide stallions sufficient for the entire requirements of the province, which is far from being the case.

During the winter season the Herzegovinian Government stallions are all colleeted at Mostar. An excellent range of stabling has been erected, adjoining which is a barrack-room for the soldiers who act as grooms, quarters for the non-commissioned officer in charge, stores, and an open-air manége for exercising. At one end of the stables stand, two in a stall, some score of Cyprus donkeys, which, like the horses, are sent out for stud work in the spring. Then come the horses, which, intended for service in a province some two hundred miles long and nearly as broad, are eight in number. Of these two are Istrian Lipizaners, a breed approaching to our hackneys; the rest pure Arabs, bred in Hungary. Although I have always been an enthusiastic champion of the pure blood of the desert, I cannot help admitting that in this country they are hardly in the right place. The pure blood with its attendant qualities should come last, and not here until hackney sires (or, in their default, Lipizaners) had, by a dozen years' use, put shoulders and substance into the ponies of the country. The results of the present system cannot be hoped to be other than weedy animals 
of rather more quality than the present ones. A particular description of each of these stallions would be beyond the purposes of this book, so I must refer the curious to the article before referred to, which concludes as follows:-

"This Herzegovinian haras is subject to the general administration of the stud for the two provinces, and the two responsible officers (major and captain) work it from Bosnia. The horses are foraged and looked after by the military authorities, their grooms being soldiers of the Remount Department. When sent out to their posts for the season they are, where possible, still under military management, otherwise the civil authorities take charge. These last lieep the records, which show exact description of the mare, result of the covering, and description of the foal. They thus form a stud-book pure and simple, which will one day be of the greatest use. The average number of mares covered by each horse is fifty. The older horses are allowed to serve once every day in the week (seven), the colts four times only per week."

The encouragement offered to breeders does not end here. As with us, there are annual colt shows with premiums; and also races where the government gives prizes to be run for by the native breed, as well as, separately, for those got by their own staillions. 
After our inspection was over, we availed ourselves of a waggon going to the town drawn by two of the Cyprus donkeys, who rattled us along at a good pace. We stopped on the way to see the three government bulls allotted to the town of Mostar. They are of the Tyrolese breed. I do not pretend to any great knowledge of cattle, so will only say they seemed to me excellently adapted to their purpose of improving the breed in this mountainous region. They are iron-grey in colour, and a little smaller than our Jerseys. Their worst point seemed to me to lie behind the shoulder. There are hundreds of these bulls throughout the province, and the number is anuually increased; but of course they are not collected in winter. The conditions on which they are supplied are different to those of the horses, of which the use is absolutely free to breeders. The bulls are handed over to the communes, who are bound to house, feed, and look after them. At the end of three years they become their property.

To show how thoroughly the Austrian Government has taken the matter in hand, I may add that they not only supply the people with gratuitous horses and bulls, but have also provided hundred of rams, boars, and even Langshan poultry. Even the question of purchasing dogs has been the subject of official correspondence. 


\section{CHAPTER XX.}

IN Dalmatia I had heard glowing accounts of the sport in the Administered Provinces; in fact, this had been a very principal reason for going there. So it may be imagined that I lost no time in proceeding to take out my licence, and in ascertaining what sport was to be obtained in the vicinity. The licence system-or rather the system of taxation thereunder-in the Administered Provinces is peculiar. Apart from the permit to cary arms, which costs $1 s .3 d$., the shooting-licence, which entitles the holder to shoot anywhere in Bosnia and the Herzegovina, except in the five sanctuaries, costs $8 s .4 \pi$.; but it is doubled if the sportsman wishes to shoot with one dog, and trebled should he desire to use two; more than two are not allowed. This strikes me as, on the whole, the very worst plan possible for collecting revenue from sportsmen; for is it not equivalent to a premium in favour of the peasant shooter, who observes the haunt of beast or bird when he is at work, and knows exactly where to lay his hand on it afterwards? 
$\mathrm{He}$ is the only sportsman (if I may so call him) who needs no dog, except indeed the stalker, for the use of beaters here requires special authorization. In my opinion, it would be better to charge double or even treble for the shootinglicence, and, as in other countries, leave the number of his dogs to the sportsman's discretion. Then, again, why should the licence expire with the year? It is true that most of the shooting ends then, but this is surely a reason in favour of allowing the man who has taken out his licence to have the wildfowl and other spring shooting included in his payment, for few people can be sure about the next shooting season. The system prevalent in most countries, of making a licence available from July 1 to June 30, should be adopted.

To return, however, to my subject. Mostar is, I think, for a town of its size, the "gamiest" place I have ever visited. Putting on one side migrants such as snipe, woodcock, and wild geese, which come actually into the gardens and fields on the right bank of the Narenta, I have shot hares within a furlong, foxes within a quarter of a mile, partridges of two sorts within half a mile, bears within four miles, and chamois within six miles, not only of the municipal limits, but of the houses of the little capital. But this is anticipating, and I 
must return to my first Mostar experiences. Less than a fortnight after my arrival I was invited to a municipal fox-drive, organized by the Sub-Prefect. The rendezvous (7 a.m.) was on the saddle which joins the isolated hill called the Hum, at the western corner of the town, to the main line of hills, and which overlooks the Česma valley one way and the Jansenica the other. Here over a score of sportsmen were assembled - officers, officials, and natives, the latter including Ibrahim Beg, the burgomaster of the town, a very genial Turk, with a weakness. for making speeches in and out of season. Before the Occupation he was in the Sultan's service here.

The first beat was on the Mostar side of the Hum; but, unfortunately, the beaters (townsmen) were in too great a hurry, and began before the guns were in position. Consequently several foxes, which were early on foot, detected the moving forms of the sportsmen, and, crossing down towards the town, escaped without being shot at. I had loaded with a bullet in my left barrel, but seeing that my position faced a suburb, and further on the town itself, and that I should probably enfilade the former, if not indeed the latter too, I changed the cartridge directly I was posted. Need I say that a fox came and stood for two good minutes some eighty yards to my 
front, and then, seeing my neighbour, whose clothes were too light in colour, he turned back.

Some years back I described in the Field the comic agony I felt on the first occasion I was bound to roll over a fox. Well, I have done a good bit of Continental shooting since then, and the effects of early training have worn off. So when an obviously wounded fox came bustling over the hilltop, and my neighbour failed to stop him, I had no hesitation in doing so. I saw nothing else during that beat, but the quantity of foxes so near the town was really extraordinary. As I have said, four or five descended towards the town and got safely away, but three were bagged. We afterwards heard that some Turks, shooting with beagles on this very ground, had accounted for three foxes the day before our shoot, and on the day after they got four, perhaps some of them previously wounded. Eleven foxes in three days, on a hill a mile and a quarter long: and not seven furlongs broad, should be a record; but yet I never throughout the winter drew the Hum blank, or heard of its being so drawn.

The next was a very picturesque and wellarranged beat, if not very productive. The guns were posted along the line of the excellent road that leads to Ljubuski, and whilst the main line of beaters, reinforced by a number of countrymen, brought up the ground between our last 
beat and ourselves, a fresh detachment swept the ground to our right, so as to join the others in the centre, close to the source of the Jansenica. Early in the beat a small light-coloured fox, probably a vixen, passed my post, but a long way below me. She probably got to ground just beyond; at any rate, she nover came to the gun, nor did several others the beaters put up. I have no doubt that on these occasions many foxes, hearing shots in front, prefer to squat in the open in the hope of breaking back, in which they generally succeed. Next an old hare stopped in front of me to consider, and then decided to make for the right of the line of guns, where she was promptly rolled over by a Turk. This beat only resulted in one fox, but he was a magnificent old dog. The next step was the important one of lunch, which had been sent from the hotel at Mostar, and was waiting for us at a Han, or wayside coffee-house. It was some time before we were again posted, this time round three sides of a plantation, at the bottom of which came the Blato, before referred to. The guns were rather thickly crowded, but few of them got any shooting, a good deal of game getting away by skirting the water. Four more foxes, a couple of hares, and a partridge was the bag this beat. For the wind-up we returned to the billside above the Jansenica valley, but further 
along. Unfortunately, a lot of natives were scattered over the ground, shepherding or cutting sticks, and this spoilt what little chance there was. At the end of the beat a leveret drew the fire of three or four guns, and departed rejoicing, amidst much laughter. I had already started off, when a lad near me, who had been attracted by the firing, almost stepped on a fox lying behind the line of guns. He nearly got away, but not quite. Then we returned to our Han, where the bag was laid out as follows: nine foxes, three hares, a partridge, and a stone-hen. Of the latter scores were seen, but as they invariably fly along the hillsides, and as the guns were throughout posted above the beaters, few were fired at. The result was poor, for with better luck, and perhaps management, we onght to have doubled our bag. However, all hands were cheery enough at the Han, where toasts and speeches were the order of the day. Need I say that Ibrahim Beg was in great form, and, among other healths, coupled that of my Queen and country with my insignificant personality. Unfortunately, as I did not understand one word of his oration, I cannot reproduce it, nor indeed my reply, for I made none.

I shall never forget the next occasion that I went out with a gun, which was about ten days later. One morning, being unable to sleep, I 
sallied out before daylight. As a matter of fact, it was a couple of hours before sunrise, but I thought it later. There was a bright moon, halfway through her third quarter, and it was really as light as day. Before I reached the North Camp, which marks the uttermost limit of the town at that end, I turned up a winding military road which communicates with the forts above. At the end of the first zigzag is a shallow ravine, and there my dachshunds at once commenced to feather about. Directly after, I heard a stone rattle at the other side of the little gorge, and, rightly guessing what had dislodged it, I cheered on the hounds. In two seconds they had crossed the valley, and went off full cry. I sat down on the roadside, very slightly covered by the biggest thornbush about. The cry of the hounds died away in the distance, and then swelled again. Then I heard stones rolling once more, and immediately afterwards a hare faced me, so close that I could not shoot. Naturally she saw mo as soon as I did her, and she disappeared. I sprang to my feet, and as I did so she crossed an opening between two bushes higher up, giving a snap-shot, which proved fatal. This was the only small game I ever shot by moonlight, which makes the morning a memorable one to me. Hiding her under a rock, I resumed my walk, and before long the little hounds were rumning 
smartly once more. But though the moon was shining brightly as ever, I saw nothing till something appeared on the sky-line a couple of hundred yards higher up. The pointed muzzle and short sharp ears were plain enough, and left no doubt as to the genus of the animal. The fox, however, got to ground presently, and I saw no more game before daybreak.

As a rule shooting near Mostar may be said to be the same as in Dalmatia, with much more game. Hares are numerous, three thousand skins being sold in Mostar in '94. Stone-hens are extraordinarily plentiful; a friend of mine, Oberlieutenant von Wurtzbach, killed 183 in December, '95. Partridges are less common, but still the keeping of a good pointer is remunerative, especially as there are the migrants to be reckoned with. Perhaps the best idea of the sport can be obtained from the description of a day of a mixed. sort. One fine winter morning I left home not long after sunrise, accompanied only by my two dachshunds. From the railway station an imposing avenue, bearing the name of the Archduchess Stefanie, has been laid out, which one day will be the centre of the Mostar of the future. At present, however, it is flanked by marshy maize-fields, a favourite resort in winter of the snipe. Here, then, we will begin.

Keeping the dogs close to me, I go quietly 
down a hedgerow towards another with a wet ditch. Scape! scape! Up gets a wisp, and down goes one bird. The dogs are wild, and dashing on, put up a lot more whilst I am getting him. I get them in again, and a little further on I bag another in an onion patch, which is always a favourite resort of scolopax. At the shot a teal rises, but though he does not settle far off, I cannot turn aside, but keep on over a low hill, and into the Radopolje plain, mostly vineyards. The Česma waters this, and just below is a favourite corner for woodcock which I cannot miss. "Hie in!" The dogs dash into. the brambles, and flap! flap! up gets a cock. It was an awkward twist, and I am a little slow getting on him, which is just as well, for as it is. he just drops neatly on the far bank. Although there are some twenty feet of icy-cold, swiftrunning water, the red dog plunges in without hesitation, and swims across. Alas for neglected educational opportunities! he has never been taught to retrieve, so I watch curiously. $\mathrm{He}$ takes the bird in his mouth, looks inquiringly at me, and, disregarding my "Fetch it," lays it carefully down and swims back as he went. Fortunately, a boy, attracted by the shot, appears, and starts off with the bird for the nearest bridge. Meanwhile I look for another, find it, and miss it. At the shot a mallard gets up with a quack, 
quack, and, totally disregarding the charge of small shot which I bestow on him, goes straight off for the Blato Marsh. Having got my cock, I cross the polje (plain), intent only on getting to the other side, and consequently am "the unready" when the dogs rout three partridges out of a hedgerow. There is another brace there, though, and one swings towards me, and is added to the bag. I had hardly expected to find so strong a covey here in December, for this is the happy hunting-ground of the Sunday sportsman. At last I am clear of the vineyards, and approach a typical bit of ground, which I must try and describe. At first blush one would say the hill is all stones, but, as a matter of fact, though there is not a tree on it, there are a good many stunted thornbushes, cropped close by the goats, and here and there a few blades of grass. Besides this there is a quantity of a grey sage-like plant, whose seeds, as I have before said, form the favourite food of the stone-hen, and impart to it a flavour which makes many people refuse to eat it. A dry watercourse forms the best way up, and is bad at that. As I am about halfway up a whistle of wings attracts my attention, and I fire (fruitlessly, of course) at the last of a score of blue rocks, and register for the hundredth time a vow never again to waste a cartridge on pigeons passing overhead. When near to the top of the hill, I turn left handed and 
follow a sheep-track similar to the Dalmatian ones. Meanwhile the dogs are bustling about, but I have not seen any fresh stone-hen sign. The hounds are busier and busier, till all at once I see an old hare stealing off through the thombushes. A snap-shot is all it is, but I am relieved to see both dogs dart to the spot and stay there. They are soon pulled off, and puss transferred to the bag. Presently they find another, but she gives me no chance, and away they go full cry. I stand to watch them, and, as I had expected, I see a covey of stone-hens scatter before them. Some I mark and follow' up. 'The dogs being still away, I walk cautiously and look sharply about. One can generally see these birds running among the rocks, but this time they have done me, for, as at last the dogs come towards me, two rise a long way behind. These must have run back. Scent is fresh enough, and, the dogs pressing on, I do the same, and so am fortunate enough to be within range when a single bird rises, and get him. "Leave it, you scoundrels." It is, perhaps, a slight drawback to these merry little customers that one must lieep with them when they are drawing upon birds. Of course they could be taught to stand, as I believe they can be taught anything but talk; but then they would no longer be the all-round dogs they are. This is a poor result, one bird out of a covey; but I have no 
mark, and as the birds are all over the place, I had better go on to a spot I know of. This is a deep valley, with covert on one side, cleft in the very top of a hill. The covert is divided into two by a little piece of cultivated land. It is a long stiff climb thither; but at last I reach the place, and in the first patch of brushwood the dogs disperse a covey. Then follows a lot of shooting, but I am afraid not much hitting, for the birds get up among the high stuff, and twist down over the brow in a very nasty manner. At last there are no more left. I haven't been able to mark very well on account of the smoke. Powder is a government monopoly here, and nitro-compounds are unknown. Perhaps it is not a bad check upon poaching that this very necessary article is only obtainable (with a permit from the civil authority) at the artillery magazines.

The absence of a mark matters less on this occasion, as a stone-fowl always runs like a hare on alighting; and I know they are all in the next bit of covert, which is higher than this and quite unwalkable, being one mass of rocks. So I walk along outside it, whilst the dogs bustle through, and get some pretty shots-mostly too good for me. Still, I stop a couple, and a driven "Greek partridge" takes stopping. One plays it very low down on me by getting up again as I go to gather him, leaving me to contemplate a handful 
of feathers on the spot where he had lain for five minutes. Then I sit down and watch the dogs, which have left the covert and are carrying a line up the opposite brae. I imagine it to have been a hare, or possibly a fox; but presently I see three birds running before them, which finally rise singly when actually pressed, and settle again lower down. I follow them up, but get none of them.

Meanwhile I have got very sick of the hare, and also very thirsty, for a fime winter day here is a warm day; so I go to a native hut just above and ask for mala voda (a little water). Precious muddy stuff it is when it comes, but beggars mustn't be choosers. Here I leave the contents of my bag to be sent in next day, and stride down the reverse slope of the hill towards the Blato. A piece of rough stuff on my way looks worth a visit. Piep! piep! up get a brace of quail. Quail in December! Astonishment and No. 5 shot may excuse a bad miss; but I have a mark on one, and, reloading with No. 9, grass him.

Here is the Blato. What a sight! Myriads of duck cover its waters, and hundreds of geese. Dozens of white spots mark swans, and there are numbers of solemn-looking herons and other waders about. As I walk along the edge I get a snipe, but the shot doesn't disturb the fowl. The bulk of the geese are on a bit of grass to which a long 
dyke leads. Well, I'll try. So I load with big shot, and call the dogs in close. No difficulty in getting within two hundred yards, and then? Happy thought, the sheep! Rare as it is to see sheep unshepherded here, these are; so I get behind them, and with great difficulty start them towards the water. Nearer and nearer we go, the sheep continually trying to break back, and the dogs getting very disobedient under these novel circumstances. I, of course, am bent double. Ninety yards, eighty; a little further and I'll try, whenthe red dog catches sight of the birds and dashes out to the right, the sheep wheel off to the left, and I am left exposed. With lond cacklings the heavy birds rise, and the duck follow suit with a roar like that of an approaching train. The game is up, let's go home.

On my way I cross a rocky knoll right at the water's edge. It is fenced in, and a nasty fence it is. When I am in the middle of it the dogs run out a hare to my right, which is foolish enough to cross the open in front of me, so I have to carry one home after all. Not twenty yards off they put up a covey of stone-hens, but it is too late to do more than make a note for another occasion. As I go up the road a flock of rock-pigeons settle just beyond a native hut. That wall will cover me, and, what is more, hide the dogs. I steal along: it till I make out one pecking amongst the stones, 
and pot him without scruple. The others rise, but the light is too bad to shoot flying now.

At the top of the little pass which separates the Blato from the Mostar valley stands a han, where, as at all these places, you get an excellent pot of coffee for a penny. Whilst it is being made I discuss a tumblerful of the heady Mostar wineno bad pick-me-up when, after a long day, you have still nearly a couple of hours' walk before you, as is my case. However, when my pipe is smoked, I feel decidedly better for rest and refreshment, but thankful, nevertheless, that the way is all downhill. These hans form a pleasant feature in Herzegovinian sport, and on many an evening I have been glad to see one in the distance. An old Luxemburg forester once told me that a sportsman should be able to go all day on "une pomme, une goutte, et une pipe," and though these form no bad proviant, I fancy the black coffee is preferable to the schnaps. The sportsman entering a han will often find a native singing and accompanying himself on a guzla. This is a mandoline-shaped stringed instrument, but is played with a bow, held like that of a violoncello. It is only used to produce one melody-if that can be so called-and that purely as an accompaniment. The singing should perhaps be more strictly called intoning, and is a decidedly monotonous nasal chant. It is, however, interesting from one point of view, and 
that is the words. In these folksongs the entire known history of the Herzegovina is contained, for there is not a word of it written. The songs deal mostly with the deeds of derring-do of the old heroes in the Turkish wars which preceded the conquest. The girls, especially when tending their flocks, sing love-songs. I once entered a han where a native was singing. He took no notice of me, but continued to do so. Presently the landlord, who knew me well, stopped him, and this I will swear, from the faces and byplay of the speakers, was the conversation:

Landlord: Oh! stop that now.

Player: What for?

$L$. : Perhaps the gentleman won't like it.

$P$.: Not like it?

L. : No.

$P$. (putting the instrument away): Well, I never! All I can say is, that if people of such want of taste come here, $I$ shall go.

(Exit wrathfully.)

I certainly was very glad when the performance came to an end; but the guzla-player, had he known it, might have consoled himself with the fact that to me all music is indifferently objectionable, for I am of the opinion of the great Jorrocks, who, when asked if he liked music, replied, "Yes, the music of the 'ounds; none of your tamboureening work. Give me the real ough, ough, ough, of a fine deep- 
toned 'ound in the depths of a rocky dell as he drags up to old Reynard among the brushwood." * Generally speaking, I found the walking about Mostar easier than that in Dalmatia. Some sportsmen use the native opanke, but a good shootingboot does most of it, though I must admit these suffer sadly. As there is not much wet walking, a stout shoe and Highland spat are even better.

" "Handley Cross," chap. x. p. 28 (original edition). 


\section{CHAPTER XXI.}

As I have said before, the majority of the inhabitants of Mostar are Turks, or, to put it more correctly, Mussulmans, for the religion is the only difference. In dress, and even language, there is no distinction between them and their Christian neighbours. At least each have a distinctive dress, i.e. their gala attire, but as a rule one can only distinguish between them by the shaven crown of the Moslem. Probably it is only within this century that Christians have been allowed to reside in the towns at all; at any rate, they could not own land till Omar Pasha's time. He much improved their position, and, though he disarmed them, invariably shot any Turk who killed a Christian, which before that time was looked on as a most venial affair, much as it is to-day in Armenia.

The Bosnian Mussulman is infinitely stricter in religious observances and customs than the Turk of Constantinople. In nothing is this more plainly manifested than in the dress of the women. The reader may recollect that some years ago 
the religious authorities at Constantinople issued a notice calling attention to the habitual disregard there of the Prophet's injunctions as to women's dress. Here it is quite otherwise; transparent veils and Parisian costumes are unknown. Not only do the women wear a fine linen yashmat, but the better classes also wear a black net vizard like a carnival mask, generally embroidered in gold. The lower classes wear a curious sleeved cloak with the sleeves always pinned behind them. This garment culminates in a high stiff collar, which, however, is not worn round the neck, but over the head. All alike adhere to the shapeless wraps and high yellow boots, in which they shuffle along, so that the passer-by cannot guess if he is looking at a girl or a crone. The men are a fine, active, intelligent-looking lot, and seem to be very observant of their religious duties.

The Mohammedan villager is, of course, very different, and his womenkind do not cover the face, though they wear cloths round it, ready to draw up over the mouth if a Western European happens to pass. Some villages are entirely Turkish, others are mixed. The proportion of creeds is-Greek Church about half, Turks about a third, Roman Catholics about one-fifth. There are no Turkish towns in the Herzegovina, in the sense that some of those in Upper Bosnia are. In the country the religion depends greatly on 
the district. For example, the entire population on the right Narenta bank south of Mostar is Roman Catholic, whereas the left bank is mostly inhabited by Turks.

Mostar has also a large number of Greek Catholics. Strange to say, these are always spoken of, not only by themselves, but by their Roman Catholic rulers, as the "orthodox." So for once Sydney Smith's famous definition, "Orthodoxy is my doxy; heterodoxy other people's doxy," is at fault.

The "orthodox" here still observe the old calendar, and this constitutes a great nuisance. For instance, Christmas, New Year, the Greek Christmas, and the Greek New Year, constitute a succession of holidays which throws everything out of gear for nearly three weeks.

The peasants of all denominations wear a fez or turban. The women dress entirely in white home-made stuff, the skirt generally fastened behind to show the trousers. On festive occasions they wear a good deal of jewellery of what is known in England as the Bulgarian type, and head ornaments, mostly of old gold or gilt coins. The townswomen wear loose trousers and zouavejackets, often a mass of gold embroidery. Their caps are similarly worked.

Of all the religions the Roman Catholics give the least trouble to the authorities, and purely 
Catholic districts, such as that of Ljubuski, are not occupied at all by troops now. The Greek Catholics, on the contrary, are naturally open to the insidious counsels of Russian secret agents, and it was they, even more than the Turks, who formed the backbone of the insurrection of 1882, of which the nominal cause was the introduction of compulsory military service. They, too, have learnt the lesson that " the Swabian is not to be trifled with (Der Schwabe versteht kein Spass)," and, as far as internal matters go, may look forward to peaceful and rapid development. Unfortunately, these provinces may any day become the cock-pit of a European conflict.

This eventuality will certainly not find Austria unprepared. The garrison of Mostar in peace time consists of ten thousand men, exclusive of the brigade at Nevesinje, twenty miles out. It is, moreover, strongly fortified. The general plan of the fortifications faces south. This is only natural, as the east is protected by the Velez range, which is quite impassable by troops. It seemed to me, nevertheless, that the position could be turned by the Ruiste pass, and one wonders why this is left unfortified. At first sight the batteries, being stome built, strike a military eye as very old-fashioned; but on reflection one sees that earthworks are impossible on hills where there is no earth. Of the troops at Mostar the 
bulk are infantry. The artillery are mostly mountain batteries, the beast of transport being the native pony. Unlike ours, the gun these batteries use is in one piece, and therefore smaller than ours. This branch is affiliated in the Austrian service to the Field Artillery, and all the officers are mounted, in contrast to ours, which is (or was) connected with the Garrison Artillery, and only has the field officers mounted. The Herzegovinian conscripts join the Bosnian regiments or the Train.

Everything here reminds one that we are under a military occupation. The post and telegraph offices are military, and, I am afraid, leave a good deal to be desired. Nevertheless, we pay more here for parcels, etc., than anywhere else in Europe. The diligences are worked throughout by military authority, the very roads on which they run being patrolled by troops.

* * * * * * * *

The administration of the Herzegovina is at once simple and admirable, and its results are a triumphant justification of the methods of civilization. If we consider what the province was--say, in 1876-and look at it now twenty years later, it seems almost impossible that so much can have been achieved in so short a time. It was then, to put the matter simply, exactly what Albania is now. There were no roads, no sanitation, no 
safeguards for life and property, no law but that of the strong hand, nothing. Now not only are there excellent roads, but a trunk railway line traverses the country. The sanitation, of the towns at any rate, is very fair. Geudarmes patrol every part of the province; robbery with violence is unknown. An excellent code is severely enforced, and before the law Austrian, Serb, and Turk, Roman, Greek, and Moslem, are equal. Moreover, as I have already pointed out, tremendous efforts are being made at improving the condition of the peasantry by helping them to advance to the modern standard of husbandry.

It is, of course, well known that for purposes of government the Herzegovina is considered part of Bosnia. In many ways the idea is absurd, for the two countries and the two peoples have little in common, but in practice it works well enough, and is economical. The entire "Administered Territory" (Occupationsgebiet) is divided into some half-dozen prefectures (Kreise), and of these the Herzegovina forms one, its administrative centre being, of course, at Mostar. The Prefect (Kreisvorsteher) is subject to the Central Government at Sarajevo. Under him come nine Sub-Prefects (Bezirlisvorsteher), stationed respectively at Mostar, Nevesinje, Ljubuski, Konjića, Stolac, Bilek, Gačko, and Trebinje. The ninth is for the town of Mostar. Under these stand directly the 
departments of agriculture, revenue, schools, forestry, game-preservation, and to some extent the gendarmerie. The system is, in fact, that of our Indian empire, reading Prefect for Collector, and Sub-Prefect for Assistant-Collector. The former has a regular staff, consisting, among others, of doctor, veterinary surgeon, engineer, school inspector, and forester. The latter, again, has also a staff of similar officials of lower rank.

For the Englishman these provinces have a sad aspect. This, he may reflect, is the result of political courage. It might have been so in Egypt but for the weakness that listened to interested politicians, and gave vague pledges of retrocession. Here Austria rules alone. Here are no mixed tribunals, no foreign post-offices, no alien newspapers. The only pressure ever put on Vienna is indirect, slight, and perhaps wholesome. Russia well knows the fruitlessness of attempting more, and bides her time, awaiting the deathgrapple for the mastery of the Western Slavs, that must surely come in time. The winner in that strife should become the master-power in Europe.

One form which the attempt to develop these provinces takes must be appreciated by all visitors -I mean the welcome extended to strangers. I do not speak solely of the courtesy and hospitality shown by officials of every degree (although I am glad to be able here to express my thanks for these), 
but of the enormous efforts made to attract travellers. At Ilidze Spa, near Sarajevo, there is an annual race-meeting with good added money. The distance is a little too far for Englishmen to send horses, but the handsome pigeon-shooting prizes might attract some, at all events, of those who also like free game-shooting.

Of course all is not yet done, Herculean as the efforts have been. To me it seemed that three crying needs of the country were roads, doctors, and schools. From the Velez to the Montenegrin frontier, and westward from the Narenta at Raskagora to that of Dalmatia, near Imoski, there is not an inch of even the roughest road. The people are born and die like their cattle; their children grow up as iguorant as themselves. No country can progress in this way. But to know these things one must leave the beaten tracks, and not one traveller in ten thousand does that.

* * * * * * * *

I also, however, have left the beaten tracks of sport, and must "hark back." I have described the sort of sport which filled up our time till the end of the year, when the stern game laws of the province cut us off from all shooting, even of woodcock and pigeons, till the next emperor's birthday (August 18). All they leave, to those who care to take out a licence on purpose, is wild- 
fowl (till end of February) and snipe. These last seem to rank here with bear, wolf, wild boar, and fox, for there is no close season for any of them. The boar, as will be seen hereafter, is very rare in the Herzegovina, and the bears do not come out from their winter quarters till April, so practically we are reduced to wolf and fox. For the former, we had two drives that winter, both towards Nevesinje. I was invited to both, but on the second occasion I was advised not to go. Of course this was the only occasion on which wolves were seen. The first one only resulted in a couple of roebucks; but on the later occasion three wolves were moved on an open hillside late in the day. Of these, one was fired at nine times, and, though severely wounded, got away. The other two broke back through the beaters, and were poisoned the week after. Wolf-shooting is always a very flukey amusement, owing to the great distances the animals cover in a night, and even if they are on the ground they are most difficult to bring to the gun. For this reason most of those killed here are poisoned. This is no doubt desirable, but the indiscriminate use of poison for foxes is less so, and many a sportsman has had to deplore the loss of a valuable dog for this reason.

In shooting from Mostar, the weather is a very important factor; and it must be admitted that the climate "leaves to be desired," as the French 
say. About half the winter days are bora days, when shooting is practically impossible. One of the most comical sights I ever witnessed was the effect of such a wind on my friend Miller, facile princeps of local sportsmen, and a snipe. The bird was anxious to go up wind, but literally could not, and presented a stationary mark. This was all very well, but it was exactly over Miller's head, and, try as he would, he could not hold his gun up against the blast. At last he did fire, and no wonder it was a miss. I deeply deplored his untimely death (in November, 1895), for he was without doubt as good a sportsman as an amusing companion. He had performed the feat of a right and left at all local game, including bears; and yet he, like all others here, asserted that in this country it was impossible to stalk chamois. In general information he was much in advance of the average Austrian officer. Not only was he familiar with the empire from end to end, speaking every language known in it, but he had resided some years in Russia.

But to return to the weather. As a rule, two or three days' bora is followed by one perfect day, and then comes the scirocco, warm and relaxing, with heavy rain for another two days. So it is a lucky week on which one can shoot twice. We filled up the early year with snipe-shooting, duckshooting, and fox-shooting over beagles. For 
duck the best place is the Hutovo Blato, near Caplina, on the Metkovic line, and given a strong bora, which makes the birds "flight low," the bag will run into three figures. Of course it involves a two days' trip at least. One day that we did have, however, was of a quite different nature, and deserves, I think, a chapter to itself. 


\section{CHAPTER XXII.}

Early in January my good friend the SubPrefect informed me he had received a communication from Sarajevo instructing him to procure a bartgïms, or buck chamois in its winter coat, for the museum there. The word literally means "a bearded chamois," and the bart, or beard, is the long hair on the.withers. It is a wisp of this which is used to make those ornaments for shooting-hats, which most Englishmen have seen when travelling in Germany or Switzerland. In accordance with these instructions, he invited Miller and myself to participate in the shoot, which was fixed for the 18th.

At five o'clock on the morning of that day I was awakened from a dream, in which I was endeavouring to stalk chamois with a field-gun, by the booming of a salute fired near the Greek church-said moise having evidently inspired my dream. There was no occasion for me to get up quite so soon, but nevertheless I jumped out of bed in some anxiety as to the weather, for it had been pouring in torrents the night 
before. The moon, which had reached its last quarter that night, was riding high in a nearly clear sky, and gave me every reason to suppose that the clerk of the weather, at any rate, intended to behave kindly to me on this my first day's chamois-shooting. I was the more lucky because we had had almost continuous rain since the New Year, which came in with cold rain, falling as snow a few hundred feet above the town. For the last few days, however, the weather had been warmer, and most of the lower snow had been melted or washed off. Still, we might reasonably hope to find chamois at a low elevation. Seeing the day promised well, I turned in again for another hour's snooze.

At seven o'clock I left the house, and found Miller waiting for me with a carriage. We were soon rolling through the town, meeting en route most of the local notables on their way to the Greek church, from whence every January 18 the bishop and clergy, followed by Prefect, SubPrefects, generals, officers, and officials of every grade, proceed to the Narenta Bridge to bless the waters. A very turbulent and muddy receptable for holy water it was this morning, we thought, as we passed one of its bends a mile out.

We soon overtook a carriage containing the district forester and two other guns, and proceeded together to a well-known han some four 
miles on the Sarajevo road, which goes by the name of its owner, Miric. Here we found the beaters assembled under the command of a wellknown peasant sportsman, by name Bosco. They consisted of a dozen stalwart and active Catholic peasants, and had ready five ponies, mostly sorry beasts enough. To me, fortunately, was allotted Mirićs own steed, a chestnut of the Podvelez breed, which, like most of these, bore on its gaskins the unmistakable scars of wolf-bites-a relic of its foal days. He informed us he had recently refused eight pounds for it, a high figure here.

Our route lay first across a mile of plain, muddy with much rain, and traversed by several swollen watercourses. In the middle of it we divided forces, Miller and I taking with us a local professor, who claimed to have done some chamois-shooting in the Tyrol. The other two were to go to stands divided to us by a deep ravine. Our way lay up a rugged watercourse past the hamlet of Vrabčicii, and then between high cliffs, on some of which vultures were gravely seated. I stuck to the saddle till we reached a spot where our ponies had to turn on their quarters with their heads and forehands over space. Then I got off, and, hearing we could not ride much further, wallied up to a sheepfold (for summer use) half a mile on. It was now 
ten o'clock, and we sat down for a smoke. In about twenty minutes we were once more on the move, the beaters descending to our left. A little further on we put up a covey of stonehens-the elevation at this time of the year being a considerable one for them-and then we reached the first stand. The scenery at this point began to be grand, although occasional fog-wreaths hid it at intervals. We were standing on a rugged mass of stone overhanging a gorge filled with beech scrub. Beyond this again came the great ravine, on the other side of which our friends were waiting. The rest of the picture must be filled in with rocks, gullies, and forest, and with several high precipices-the favourite refuge of the chamois, especially from wolves. Above us was another ravine, backed by stupendous cliffs, and behind that again the hills trend back to the main Velez range. At this point we left the professor, and continued our upward march. We were soon amongst the snow, for we had now reached an elevation of something like 2000 feet.

A hundred yards further brought us to an angle of the rock, and as they reached it I saw Bosco and Miller, in front of me, drop like setters. I crawled cautiously up to them, and across the next gully, five hundred yards away, I saw my first chamois. Almost at the same 
moment a movement to the right caught my eye, and a lämmergeier swept over us. The bird is unmistakable even at a long distance, but we were near enough to see the curious feathers under the chin which give him his second name of bearded vulture, and the tail, not unlike that of the green woodpecker in shape.

We held hurried council as to our next step, waiting meanwhile in the hope that the buck would feed downwards towards the beaters. This, however, seemed to form no part of his programme. Meanwhile I had caught sight of another single chamois, which fed out of some bushes on a snow-patch high above us, and directly afterwards three more moved across to the left.

"Well, we can't wait here all day," said Miller. "If he won't move, we must move him. Very likely there will be some more in the dip behind this knoll."

We moved slowly on, Miller in advance. The knoll in question was a rock on which a few stone pines were growing. When my companion reached the upper edge, he dropped back and signalled to me; and then, without waiting, fired. I sprung to a pine on the left as the rifle cracked a second time. Hardly had I done so when a buck chamois plunged downwards through the snow with tremendous bounds. I watched his pace for a moment, and then, taking a rest against 
the tree-trunk, I aimed a couple of lengths in front of him and pressed the trigger. It seemed to me that he slowed down a bit, but on he went. I gave him the other (smoothbore) barrel, not with much hope of a result. Before I could reload, he stopped in the thick of the beeches and stamped his foot, which wounded animals often do. Then with a shrill whistle he disappeared down the ravine. It seems that Miller's first shot-a long standing one-had so echoed among the crags that the buck had been unable to locate the firer, and had started straight towards us. Something-perhaps the smoke-had caught his eye, and he had bent to our left.

After this I had very little hope of any result to the drive, but we took up our positions, and in an hour or so the beaters reached us. All I saw was a back half a mile below me, too grey for that of a chamois, probably that of a roe. Then fog-wreaths came driving down, and that too was lost; when it cleared again nothing was in sight. For the rest of the beat I saw nothing but the great vulture solemnly circling round, and heard nothing but the shouts of our beaters and the yelping of their curs. These dogs brought a line up to Miller (who saw nothing), flashed past him, and picked up the stale line of the chamois beyond.

The next thing to be done was to return to 
the professor, and get out our lunch. Besides the six chamois we had seen, he had counted a herd of eight going up to the main ravine above. us. He positively asserted that the third shot fired, i.e. my first, had struck the chamois, but rather high and far back; and this was corroborated by the beaters, a wounded buck having passed through them and downwards. The fact of the animal's descending so persistently in itself proved the correctness of the story.

We sat down to lunch under a fine pine tree, on one of whose branches a bunch of misletoe was hanging. I do not recollect ever seeing such a thing before, but I frequently saw it growing so afterwards in the Herzegovina. Hardly had we begun lunch when, with a burst of music, the dogs drove four roedeer down the glen beneath us. Of course, it being the close season, none of us moved; but Busco, who was behind us, broke the leg of one, and the dogs caught it. I was disgusted at the unsportsmanlike act, and reported it to the forester in the evening. I thought he took it very coolly, and no wonder, for I believe he and his friend on the other side of the ravine had shot two does. If this is (and it is) the spirit the Forest Department brings to bear on game preservation, the sooner the matter is taken out of their hands the better.

It was a thousand pities that we had come on 
our game on, or rather just over, the position we were about to occupy, but of course it could not be helped. We should have taken higher ground, but the couloirs leading to the upper ridges were deep in snow, and it would have taken us all day to get there. Had we had no beaters, we might have drawn off on first sighting our game, and then, descending to the great ravine, worked up it to a higher level, and done an effective stalk. But the snow might have made it difficult; at any rate, it would have taken all day.

Lunch over, we descended to the sheepfold, where our ponies were waiting, patiently grazing. We all preferred walking to riding down such ground, and went on foot to the plain. Here we met the two others returning, who ingenuously said they had seen no chamois. After a cup of coffee at Mirić, we drove home, reaching there before the cry of the muezzins from the minarets summoned the faithful to evening prayer.

The buck was brought in next day, or the one after, but I never saw it, as the Sub-Prefect, in accordance with his instructions, sent it off to the museum at Sarajevo;

"And there it stands unto this day, To witness if I lie."

This was the last occasion on which I used the little weapon that had been my companion in 
Dalmatia, though it sometimes served me as second rifle next winter. In future I used a ball-and-shot gun, with most satisfactory results, as will appear hereafter. This was an Austrian-made weapon; and $I$ had reason to be satisfied with it. Still, to those who contemplate following in my footsteps, or taking similar trips, I would recommend an English one, and especially those made by the London Armoury Company of 114, Queen Victoria Street. Since leaving the Herzegovina I have placed an order with this firm, and have had every reason to be pleased with their execution thereof.

The wild-fowl shooting ended with February, and thenceforth, with the exception of the short migration of the solitary snipe, there was no work for the gun or rifle till the bears chose to come out of winter quarters. 


\section{CHAPTER XXIII.}

THE country, as opposed to the towns, of the Herzegovina is almost unknown to the traveller. Few but wandering sportsmen like myself know the wild beauties of the Upper Narenta, or the bare wind-swept plateaus fringing the old Ragusan Republic. The "mere sportsman" (to quote an epithet recently applied to myself) is, however, sometimes an observer of other matters than his game, and the attention of the most casual of the tribe can here hardly have failed to have been drawn to the oft-recurring memorials of a longforgotten, though by no means pre-historical, people.

As far as I know, the singular beings of whom I am about to write have left but one class of evidence of their being-their last resting-places. The superficial observer, moreover, is very apt to be thrown off the scent of their existence by the fact that their burying-places have in many localities been adopted by either Turks or Christians, so that we find their tombs mixed with the crosses of the "orthodox," or with the turban-headed 
pillars of the Moslem. Another red herring drawn across the scene of the inquirer is the answer the peasant always gives to inquiries about these graves. They are "Grelio greblje" (Greek graves).* Yet, as will be seen, no answer could be more erroneous. The strange part of the matter is that their history does not fall in so remote a period as their oblivion would suggest. Besides, some of their customs, e.g. the dance of death, so often represented on their tombs, are cited in the popular ballads, as I have said, the only history of the Herzegovina. In at least one instance they are superimposed on tumuli, as if still further to confound the issue. This, however, is quite accidental, the tumulus in all probability being of the Bronze Age. Some of the Herzegovinian tumuli are of later date, having been found to contain glass objects, but all are far anterior to the tombs of which I am writing.

That there are plenty of them to study must be conceded, their number having been calculated at 140,000 , while thousands more have been destroyed for road-making and other works in the last twenty years. Of these large numbers, however, the greater quantity are found collected in extensive cemeteries, on or near the old caravan route from the Adriatic to Niš and Constantinople.

* In one district the answer is that they aro Lutheransice greblje, which comes a good deal noarer the mark. 
The single graves and small groups the sportsman comes across far from all roads or houses are not so numerous as the above estimate would lead one to imagine. Near Mostar there are singularly few; indeed, I only recollect two or three near Suhidol, and also near Rodoc.

The graves in question are invariably covered with huge stones, very often of quite a different type to the stone of the district, though in some cases no trace of a road enables one to guess how such blocks could possibly have been transported to the place where we find them. The great majority of these monoliths are of the shape of a sarcophagus. Another common variety is best to be compared to a conventional house-an oblong with a peaked roof. Sometimes its walls also slope inwards below. Cubic and oblong blocks occur also, and sometimes what one might call a flat tombstone. Other styles are rarer. Many of these stones are ornamented, as a rule in a very primitive manner. The ornaments comprise crosses (and it is to be remarked that these are purely conventional ornaments, not Christian symbols), crescents (originally a Byzantine, not Moslem symbol, and here also purely conventional), stars, suns, wreaths, rosettes, spirals, and swords. The more elaborate tombs sometimes present groups of figures, battles, the dance of death, or hunting scenes. On a tomb near Konjića these 
last two subjects are somewhat incongruously combined. The hunting scenes are full of life, the beast of chase generally being the stag, then common in the country.

On some few there is a legible inscription. To these I will return later on, preferring now to say something of what is known of the people who lie buried under these monoliths. I think I should take the opportunity of expressing my indebtedness. to Major-General E. von Kählig, from whose article in the Dertsche Rundschau I have condensed the. following :-

The sect which raised these stones was known as that of the Bogumilites. It flourished in the days of the Hungarian supremacy, and its existence was the cause of the fall of Bosnia and the Herzegovina into the hands of the Turk.

The heretical doctrines of the Manichœans had been preached by Armenians in Thrace as early as the eighth century. With these Armenians the Bulgarians were in close communication, and as early as the reign of the Tsar Boris complaints were made that Armenians were preaching in the country. They seem to have found a fertile soil for their labours, for the complaints go on increasing until, in the reign of Tsar Peter, there appeared a priest named Jeremias, who assumed the characteristic surname of Bogumil, and gave its name to the entire heretical organization. 
The faith of the Bogumilites can best be compared to that of some of the earlier of the reformed Churches-to that of John of Leyden, of Huss, of the Albigenses, and Waldenses. They rejected the Old Testament, Mariolatry, the Sign of the Cross, Transubstantiation, and Baptism. Their faith in the devil, to whom they gave credit for the creation of the world, seems to have been very vivid; and in their simple churches, where nothing was to be found but the gospel laid on a whitecovered table, a sentry stood day and night to guard against his wiles. It was, perhaps, because they gave him credit for the creation of woman that they held married life as a sin. They thus naturally rejected the sacrament of marriage, their weddings being purely conditional. The Bogumilite was at liberty to put away his wife if he alleged that she did not live in the fear of God, and virtuously, and that she had no good character.

Bogumil no doubt soon realized the difficulty of keeping a church going literally on the principles laid down in the "Sermon on the Mount." So he early divided his people into two partsthe martyrs and the "perfected." The latter, who towards the end of the thirteenth century numbered some four thousand, seem to have been the priesthood of this sect. They were vowed to celibacy, and to abstinence from flesh 
and wine. Their duty it was, when a blow was struck at their commune, to "turu the other cheek," which does not appear to have prevented some less perfected number from returning the blow. They preached also against the bearing of arms and against war, but neither did this prevent their flock striking forcible blows against both Papists and "orthodox" when they got the chance.

Every believer was obliged to be received at least once in his life into the ranks of the "perfected," by a solemn rite resembling marriage. But this ceremony freed him from repentance at the last.

These and other decidedly opportmist doctrines account for the rapidity with which the tenets of Bogumil spread. Almost equi-distant from Rome and Byzantium, Bulgaria, like the rest of the Balkan peninsula, was at that time dominated by a spirit of umrest which had prepared the way for a new religious movement. Little time, however, elapsed before persecution began. To shorten the story of years of struggle, it may briefly be said that the Bogumilites, suspected, sought out, and persecuted everywhere, gradually fell back into the mountains of the Herzegovina and Bosnia. For the first century of their existence in Bosnia they seem to have been but little troubled; but later on, as the 
Bosnian kings leant more and more on the Hungarian throne, a frequently made condition of support was that energetic measures should be taken for the suppression of this heresy. One result of this was that many Bogumilites publicly conformed to the Catholic Church, whilst privately retaining their own faith.

In 1443, Thomas, son of Stephen Ostoja, was elected King of Bosnia. Like his ancestors, he was a Bogumilite, but, confronted by double danger from his own vassals and from the Turks, he too turned for support to Hungary. The Pope vainly endeavoured to induce him to take an active part against the heretics. But what religious feeling could not do, policy did, and at the instigation of John Hunyadi he embraced Catholicism. Rome and Hungary now demanded energetic measures, and as a result of these, in 1450 , the Bogumilite priors, many nobles, and nearly forty thousand of the people fled, partly to Stephen Wukčić, Voivode of Chlum, to George Brankovic of Servia, and to the Turks, whose absence of outward ceremonial seems from the first to have attracted the Bogumilites, who were ever more ready to embrace Islam than either Eastern or Western Christianity.

Stephen Wukčic had long sought the opportunity to throw off the Bosnian rule. He now recognized the claim of the Emperor Frederick III. 
to the Hungarian throne, and received from him the title of Duke of Sava. From this period dates the name of Herzegovina. Thomas naturally was little likely to sanction the proceedings, but died during the ensuing war, and was succeeded by his son Stephen, the last king of Bosnia, who was crowned at Jaice by the Papal Legate.

Stephen's reign opened with better auspices for the monarchy, but Bogumilism seemed to be destined to be the rock on which Bosnia was to founder. Although peace was made with the Duke of Sava, King Matthew of Hungary, himself threatened from within by the Hussites, who certainly were in communication with the Bogumilites, and from without by the Hussite George Podiebrad, like himself a pretender to the Bohemian crown, stirred up Stephen to energetic measures against the heretics.

The end was now near. Many of the Bosnian magnates were already with the Sultan, and those, who had outwardly conformed to the Church, were in secret communication with him. Mahomet II. marched into Bosnia, and appeared before Bobovatz on May 19, 1462. The commander of this impregnable fortress, Knez Radak, a Bogumilite in secret, surrendered it almost without any attempt at defence. Shortly afterwards the last Bosnian king was captured and beheaded. Nearly all the nobility embraced Islam, and no doubt the bulk 
of the common people, though more gradually, did the same. No record of the date of the last conversions exists, but the last Bogumilites are said to have lived near Jablanica, where the Rama joins the Narenta, and ultimately to have become Mahometans. If any trace of this faith exists to-day, it is in some of the customs, ceremonies, and superstitions, which we find among the Herzegovinian Turks.

I now return to the inscriptions, which will be more easily understood after reading this short sketch of the sect. The two following translations are from Ladjevina, near Rogatica. The first is on an oblong block, 9 feet by 6 feet by $3 \frac{1}{2}$ feet, and reads from right to left, as follows:-

"In the name of the Father, and the Son, and the Holy Ghost. Here lies Vlatko Vladevié, who had neither father, mother, son, brother, nor any person, only his sin.* He travelled through many countries, and died in his own house. His Voivode Miotos and his allies erected this stone with the help of God, and by the grace of the Duke Paul, who buried Vlatko, calling on God."

An adjoining stone, 8 feet long, 5 feet high, and 40 inches wide, reads: "In the name of the Father, and the Son, and the Holy Ghost. Here lies the Voivode Miotos with his son Stiepko, at the feet of his lord, Vlatko Vladjević, whom he served. * I.e. his wife, according to Bogumilite ideas. 
faithfully during his life. After his death he erected a tomb to him with the help of God, and by the grace of the Duke Paul. And bury also of this family, at the right hand of the Voivode Miotos as many as ye wish. By my hand on this soil, to whomsoever it may have belonged, no one has died, or been killed in a punishable manner."

(A strange commentary on the above is found on a tomb eight miles away, the inscription on which runs: "Here lies Grabaća, the faithful (wife ?) of the Voivode Miotos, and here....")

Both these huge tombstones are of a red limestone not found in the neighbourhood, and, from the orthography of the epitaphs, are referable to the earlier Bogumilite period.

At Han Brankovic, in the same district, is a peculiar tomb, probably referable to the end of the period, the stone being an upright pillar, exactly like those of the Turks, but without a turban. The inscription is headed by a curions representation of an animal (possibly a greyhound), crowded to one side by a rude sword. On the other sides are crescents, suns, rosettes, and on one side a head (? a skull). It reads: " . . and he fell in the battle of the despot. This tomb of Mahomet Brankovic, although on his own property, the Petrovupolje, was not brought here nor inscribed by his own hand." The forbidden representation of animal life on a Mahometan tomb is curious. 
It has been conjectured that it covers the restingplace of the first Mahometan Brankovic. The family still exists.

Only one of all these tombs is known to have a date, and is at Višegrad. On it is sculptured an arm holding a sword, and a bow and arrow, the former indicating the warrior, the latter proving he was also a sportsman. This is the inscription: "+ Q (Died in the year 1000). Here lies Joseph, the son of Joseph Nosako, with his mother Rose." The two marks which give the $Q$ its numerical value are wanting, but this is probably a clerical error.

Speculation is generally idle, but one cannot help wondering whether, if Bogumilism had survived to our day, it would have sunk to the level of the gross superstitions which pass as Christianity, Eastern and Western, in the Herzegovina. 


\section{CHAPTER XXIV.}

If I have dwelt at such length on these old-world heretics, it is because their tombs, more than any natural feature of the country, are connected with the memories of every sportsman in the Herzegovina. How often have these monoliths not served me as convenient seats for lunch, or places for my followers to lay down their burden of roebuck or chamois, or even as a screen behind which one could smoke a quiet pipe, sheltered from bora or rain!

At last the season when Bruin awakes from his winter sleep came round. In my opinion, the most sportsmanlike method of bear-shooting is to follow up his tracks in the snow or soft ground, using more precaution as they become fresher, until the animal is either discovered feeding or breaks with a crash from the underwood, when a bullet only will arrest his headlong flight. An unwounded bear is rarely bayed by dogs, and when he is so set up he has a nasty trick of hurling branches or stones at his assailants, which may result in the loss of a valuable auimal. Stalking 
- the Himalayan method-is rarely successful in Europe, perhaps because rarely attempted. Still I tried it myself on many occasions in the Velez, but never saw one, though they certainly were about. Nor are bears often shot in the Herzegovina by tracking. So much of the country is bare rock or forest with rocky subsoil, that no track is left by an animal. Once, as will be hereafter related, I had a chance on the snow. Cases are not wanting where a wandering gunner, intent on other game, has come upon bears. Two such occasions are within my knowledge, on one of which capercailzie, and on the other chamois, were the objects of chase. But these occurrences are so rare that they would by no means justify one in wasting one's time going out for such a purpose. Consequently, nine bears out of ten that are killed here are shot with beaters. The first step is to locate the bear or bears, for they are generally found together. For instance, five were killed in two drives near Ulog in October, 1894, and three in one beat in the Bjelopolje, near Mostar, on May 2 of the same year-two, right and left, by my poor friend Miller.

As is well known to most sportsmen, the bear spends his winter hybernating in what is called a gaura. In wooded countries this is sometimes a hollow tree, and sometimes a sort of made nest between several tree-trunks. In the Herzegovina 
it is invariably a crevice in the rocks. He prepares his bed in autumn, and visits it occasionally to see if it is all right. Should he notice any suspicious sign, or any taint of man, he at once forsakes it and the immediate neighbourhood. If all be well, he enters it at the beginning of winter, and blocks up the door with branches and leaves, trusting to the snow soon to cover up the signs of his presence. Only one bear occupies a gaura, the only exception to this rule being that cubs accompany the mother.

When the snow melts the bears reappear, generally about the middle of April in the Herzegovina, much about the same time that the cock-ofthe-woods begins his noisy courtship. The first knowledge the peasant generally has of the matter is derived from the marks of the digging with which the starved animal at once busies himself. As a rule, the Herzegovinian bear is a vegetarian, and his favourite food at this season is the root of a calladium-like plant (Arum italicum), whose huge variegated green leaves may be seen everywhere among the rocks in spring.

The first intelligence of the bears reached Mostar on April 18. Traces having been found by the peasants, the foresters investigated, and two, mother and cub, were seen in the Bjelopolje, just where the successful drive had taken place the previous spring. The hunt, however, could 
not take place at once, because a member of the imperial family had signified his desire to be present, so the first step was to telegraph to him, and, on a reply being received that he would arrive on the 23rd, the following day was fixed for the shoot. Forthwith the capital became unbearable. Nothing was talked of but the animal and the means of his destruction, nothing discussed but rifles, bullets, the art of driving bears, and so forth. Men who had never shot anything bigger than a hare (and not many of them), suddenly came out as authorities on big-game shooting. Great was the demand for rifles; but, as a rule, the sportsmen contented themselves with gendarmerie carbines, -450 bore, but with a much smaller powder-charge than our old Martinis, and, of course, solid bullet. I, of course, stuck to my shot-and-ball gun, with which I can smash a wine-bottle at a hundred yards. The genial prefect of the province, Baron von Benko (since promoted), alone took things with the philosophy of the old sailor, but the foresters and gendarmerie nearly worked themselves into a fever, while the district sub-prefect decided to sleep on the ground on the eve of the eventful day. All being ready, the question was this, "Will the bears stay on the ground?" The idea that an exalted personage should take a forty-eight hours' journey for nothing was appalling to the official mind, while the sportsmen naturally hoped that so 
keen a member of the fraternity of St. Hubert would not prove to have taken so much trouble for nothing. If H.I.H. the Archduke Leopold Salvator could only shoot the bear, not a bear, but the well-known giant of the Velez Range, the hero of heaven knows how many drives, who had hitherto always managed to save his skin, either by luck, cunning, or bad shooting! It is true he had not been seen this time, but that proves nothing, as many as seven bears having been known to be in a beat where only two or three had been reported. Every precaution had been taken to prevent the bears from being disturbed. The peasants had even been forbidden to pasture their cattle on the ground; although this might be considered unnecessary, local records pointing over and over again to successful drives where the bears had been for days literally feeding amongst the sheep, in one instance within a furlong of a main road, a route of much traffic, and daily patrolled by troops. The big bear of the Velez is, however, said by the peasants to be a "slaughterer," i.e. has turned cattle-eater, just as tigers do in India when they get old and heavy.

On Sunday, the 21st, the bears were reported to be still on the ground, and a telegram to that effect was sent to the Archduke. The final arrangements were now made. A rough sketchplan, showing the position, was distributed to 
every gun. The centre showed the ground, the twenty-six different posts being indicated, by numbers, with an index of names on the right side. At the top of the plan ran a line of precipitous cliffs, forming the edge of the beat. Next to these was the Archduke, then his chamberlain, the generals of the Mostar garrison, prefect, and sub-prefect. The remainder of the first line was made up of seven more guns; the second line, equally strong, was some distance behind the first. Besides this, the spots where bears had been shot in recent years were indicated by crosses-thirteen of them, of which six were at the stands allotted to the Archduke and his chamberlain. The position of the right-hand gun of the first line adjoined the hillock known (but only of recent years) as Medjedi Kul, the Bear's Peak. On the left-hand side of the paper were the simple rules for the shoot, which ran: (1) Only bears to be shot at; (2) no shooting except directly to the front or rear allowed; (3) the allotted posts not be exchanged without permission.

Nothing remained but to watch the weather, which, however, remained bright and fine. On the Tuesday evening the Archduke arrived. I don't think Englishmen can ever really get used to the peep-of-day hours affected by continental sportsmen. In this case the bears-if there were 
any at all-were on the same ground at all hours of the day. Certainly we had a couple of hours' climb before us, but even that did not seem to me to warrant such an early departure, so that I groaned in spirit on receiving an invitation from our popular prefect to breakfast with him at 5.15 a.m. However, the morning broke so bright and fine, that it really was no difficulty to be up at half-past four. A hearty breakfast discussed, we drove to the Hotel Narenta, where I had the honour of being presented to His Imperial Highness. Our carriage then piloted his out to Mirichan, before mentioned. Just before we reached it we passed two large bodies of stalwart beaters, each under the charge of several gendarmes, wending their way south. All the other guns had assembled before we arrived, so a start was soon made towards Suhidol. I could not help thinking, as our long cavalcade wound its way towards the mountains, that we might have furnished an artist with a capital study of "Bandits returning to the hills," especially as far as our saddlery went. My steed, for instance, was caparisoned with an ancient Turkish saddle covered with white home-made material. The two shovel stirrups were supported by strings of unequal length; and an ancient weather-beaten bridle, with the usual severe Turkish bit, completed the equipment. I, howerer, was distinctly lucky, 
as many of the others had to content themselves with a pack-saddle pure and simple. Besides, the bright-coloured dresses of continental sportsmen lend themselves to such a picture. The track had not improved since our January chamois shoot; but, except for the bad going, it was a delightful ride. The further we went the higher grew the scrub. Violets, already quite over in the plain, blossomed everywhere, and the hillside was covered with laburnum in full flower. For beauty of colouring the first leaves of the beech were perhaps hard to beat, but the brown of the sycamore ran them close.

As the beaters were to begin at ten o'clock, it soon became obvious that we had too much time. Soon after eight we sighted our chamois ground of January last, but bore to the right of it and also of the sheepfold, where we then left our horses-of which more anon-and skirted the rounded hill of Komic. At last a towering rock above us is pointed out as the Bear's Peak, and the second line of guns branch off towards their posts. We are approaching a couloir, up which surely no horse can go. When we reach it, however, we find a zigzag track, about as bad a place as horse ever laid shoe on, but our horses go up it without a mistake. A few minutes later we reach the ground, and the horses are led back to Komić. When we take up our posts, the ground 
turns out to differ a good deal from the rough plan. The three guns under the precipice certainly are on a line of rock facing the beat, but No. 4 is in the re-entrant behind this, where a cattle path leads up; Nos. 5 (my post), 6, 7, and 8 on a ridge thrown back from the first one, and the others on a third ridge echeloned behind ours. It was a little after nine when we reached our posts (mine, by the way, was the one where Miller had made a right and left the previous year), so there was plenty of time to rest. I ate my "piece," had a drink and a pipe, and then prepared my stand behind an old ash tree. From ten o'clock to eleven nothing broke the silence but the movement of the birds of all classes, from the flutter of wrens to the heavy whirl of the lämmergeier. From my post I could almost see the first vineyards opposite Mostar. Directly beneath flowed the Narenta, flooded with melting snows, whilst to my right peak after peak shone dazzling in the bright sun.

About eleven o'clock the first shouts of the beaters became audible. It had been arranged that the gendarmes who accompanied them were to fire signal shots as soon as the game was on foot. At a quarter past eleven I was beginning to lose hope, but five minutes later the shouts changed to shrill cries of "Hoo Medjed!" and not one but five signal shots rang out. No. 3, 
Lieutenant-General Hoffmeister, began to handle his rifle suggestively, and I rose noiselessly from my seat to stand behind my tree. Just then, to my great surprise, an Express cracked twice on the extreme right of our ridge. (I may say here it turned out to be No. 8, who, having had the game in sight for some five furlongs, could not resist the temptation to a game of long bowls, whereby he did no good, and risked doing a great deal of harm.)

Immediately after, I saw a bear coming at a hand canter up the sheep-track I have described. Now, this path led directly to No. 4 post; and perhaps, strictly speaking, I should have left the shot to him. Be that as it may, the fact remains that as Bruin passed a clear space eighty yards away, just so that I could comfortably take a rest off my tree, I could not resist taking him just forward of the shoulder. His foreleg gave at once, and he rolled over. With something between a growl and a moan, he recovered his legs; and as he did so I fired the other barrel at the same spot; and several other shots rang out. During the rest of the beat I heard him at intervals, but imagined it to be merely a case of convulsive struggles among the brushwood.

The beat ended in silence, and Miller and I with a forester entered the brush to search for "Brer Bar." Imagine my surprise when he got 


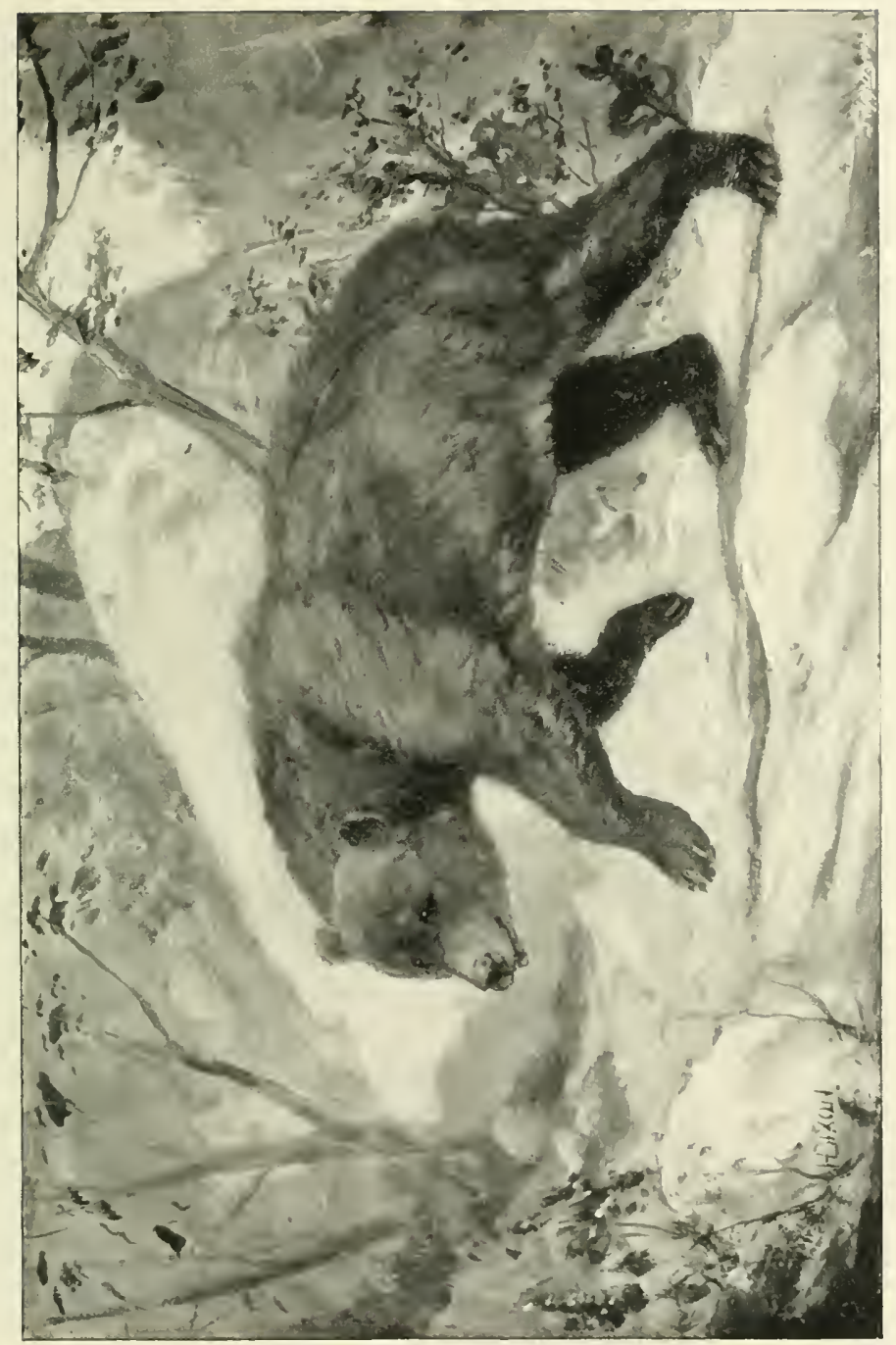

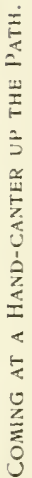


up and shambled slowly off, his right side being towards us this time. Two or three shots only had the effect of making him turn half vicionsly on the nearest of his persecutors. Then he went on a little further and disappeared. Advancing cautiously, we found him lying at the bottom of a natural pit some twenty feet deep, where the forester, after two or three shots, despatched him with one in the ear. When the beaters came, we hauled him out. He had altogether eight bullet marks on him, of which I had little hesitation in claiming two large round ones on the hinder part of the left shoulder-blade as those of my shot-andball gun. None of the others except the last were well placed, but there was one through the back which had glanced off a rib. Consequently I was rather surprised when the general claimed first blood. It seems he had fired simultaneously with myself, and very possibly the shot in the back was his, as he fired from above; but, I may remark, so did the forester into the pit. I subsequently asked for the bullets taken from the animal, but did not succeed in getting them. Nevertheless, I never had less hesitation in claiming a head of big game.

The beat being over, the guns assembled. H.I.H. took his bad luck like a sportsman, and refused the pelt, which however was sent with him the next day. The bear proved to be a small male, 
estimated at three years old. Singularly little other game was seen during the beat. I fancy three wild cats, as many hares, and a few stonehens made up the list. But whilst the beat was in progress we had been "taken in reverse" in the most impudent manner. Two wolves attacked the sheepfold before mentioned and carried off a kid. The cries of the women and the barking of the dogs were plainly audible to the sportsmen in the second line of guns.

The next step was to descend to the knoll of Komić, where the Austrian colours were floating in the breeze. Here an excellent lunch from the hotel and plenty of drinkables were awaiting us. During our meal we and our quarry were photographed from every point of view. It was a decidedly cheery and garrulous band that started down the hill a couple of hours later. Some rode and others walked, I personally choosing the golden mean of walking down the steep part, and then riding on. At Miričhan we found a gaily ornamented artillery waggon waiting. There, midst flags, streamers, and green branches, poor Bruin was placed, his head and paws gracefully arranged over the tailboard, and we started back for the town.

So ended a shoot which I look upon as memorable for two reasons. Firstly, it was the first royal shoot in which I ever took part; and, 
secondly, that I think the arrangements, down to the smallest details, were more perfect than on any similar occasion at which I have been present. Yet, in spite of so much care, only one bear out of four came to the guns, for three others descended towards the village of Suhidol, and outflanked the beaters. We should have had another beat for these; but the authorities decided that in future this ground should only be driven for " distinguished visitors." I spent a long day trying to stalk these bears, but only saw their fresh traces. 


\section{CHAPTER XXV.}

Mostar, being an impossible place of residence in the summer, partly on account of the heat, and partly on account of the pappadacci, * we had now to think of making plans for the ensuing season. Our first idea was to return to Dalmatia, of which we had left a good third unexplored, but the better prospects of sport in the Herzegovinian hills made me waver. At any rate, we would go and look at them, if for no other reason than that so few people had seen them.

The Velez Range, though not really the highest of Herzegovinian mountains, is in many ways the most important chain in the country. It is only nominally separated from Porim and the otter hills on the same bank of the Narenta to the northward, and with them it may be said to mark the limits of the ordinary tourist. So much the worse for him, for all he sees is the bleak treeless valley of the lower Narenta, whilst the magnificent

* A sort of small mosquito, most difficult to guard against, and whose venomous bites leave a mark for months. It seems to be quite a specialty of Mostar. 
gorges, forests, and precipices of the highlands remain a sealed book to him. Whilst on the subject of the Velez, I may take the opportunity of saying that on the Mostar side it slopes, not very steeply, from its upper ridges to the tableland of Podvelez, from which again a steeper slope forms the actual valley of the river-a very different formation, as will be seen, from its eastern side.

After a long-continued spell of bad weather, we left Mostar on a day which, though dull and threatening, just held out the faint promise that it might hold up, and drove past Miričhan to Potoćihan, a couple of miles further on. Here our steeds were awaiting us. My wife's saddlea cross one, for we had been ridiculously misinformed that the hill paths were so narrow as to prohibit the use of a side saddle- was soon transferred to a sturdy twelve-hand pony, mine being ou a rather larger one, whilst a woe-begone chestnut was loaded with our luggage. I should have done better to have got out the waterproofs, but standing about in a chilly wind and clouds of dust was anything but pleasant. Our guide thought it would not rain that morning, and as time enough had been lost adjusting our borrowed bridles, etc., *

* A saddle, not too large, and bridle, should form part of every traveller's equipment in the Herzegovina. Pack-saddles are useless, as the natives only unilerstand their own, but had I the trip to do over again, I should certainly buy a riding pony for myself. 
I left them in the packs, and we started. Our road sloped gently upwards, and was, for a bridle-road in this country, wonderfully good. It led through a good-sized Bogumilite cemetery, otherwise there was nothing of interest. At the end of nearly two hours we reached the head of a deep gorge, almost entirely surrounded by castellated rocks, the snow lying deep between and below them. Our guide pointed up and said, "Divokože," and certainly it looked likely enough ground for chamois. By the way, the local name for chamois literally means wild goats; and it is just worthy of remark that among the tame goats here I have come across specimens ridiculously like chamois in colouring, face markings, etc. Still, I cannot believe that it would be possible for antelope and goat to interbreed, still less have a fertile offspring. The opportunity would not be wanting, for in the rutting season of the chamois (here last week of October and onwards) the flocks are just feeding off the lowest of the summer pasture, and the chamois are also low down. I have repeatedly known the two animals to be within half a mile or less at this season.

Our way now lay up the northern slope of the ravine, and wound up by a new and excellent bridle path (actually with bridges over the watercourses!) to the pass itself, which is about three thousand feet high-an altitude which made us feel the cold 
considerably. Just as we reached it, down came a driving storm of hail and rain. We pushed on, and a few furlongs down the other slope we reached the little gendarmerie barrack of Ruiste. It is a bleak and lonely spot, and, standing as it does on a little knoll, is exposed to every wind that blows. In the past winter the snow cut off the inhabitants for some weeks from all communication with the outer world.

These gendarmerie posts are indeed a blessing to the traveller in the occupied provinces. Few of them are without a stranger's room, and even when they are, a makeshift can generally be obtained in the barrack-room. Not only are quarters to be had, but board and attendance, at a charge, including fuel, light, and attendance, of something like two shillings a day. Of course the food is plain, but good. We had arrived wet through, at all events about the knees, but a roaring stove soon dried us. After an hour's rest we remounted our ponies, which started off much the better for their corn. Our way led down a broad pass, where the rich black soil was covered with luxuriant grass. The woods fringing the bottom of the Ruiste peak (over 5100 feet) had a very park-like effect, but on the upper slopes the beeches still stood leafless in the snow. Our road skirted the hill, and, bearing to the right, entered a stone-covered waste, known as the Little Zimlje. 
Here again we passed through hundreds of Bogumile graves, each covered with a great block of stone, but of life there was no sign till we reached Kušici village, whose graveyard, full of turban-headed stones, proclaimed it to be $\mathrm{Ma}$ hometan. Here we saw the first ox-waggons. These seem to be peculiar to the tableland we were entering, at least I never saw them except in the Nevesinje district. Of course they are very rude constructions. The wheels are in four pieces, and, as I found out afterwards, are natural curves. All the young trees in these hills are bent by the snow in winter, and on steep slopes retain a sharp curve just above the ground till they are about twenty years old, when the lower side grows downwards to meet the earth. When the curve reaches its full development, the peasant cuts as many as he requires, sixteen to each waggon, and taking away the curved piece of each, perhaps two feet long, leaves the rest of the wood to rot. I am pretty sure the Zimlje waggons never even reach the Neresinje plain. At Kušici, the Great Zimlje, which is cultivated, begins, and we rode through some miles of young corn, passing the Christian villages of Sarica and Padežine to Dnopolje. Sportsmen may note that the summer residence of the Dnopolje villagers, called Smrcanj, is about as good a site as any in the Velez for a chamois shooting-camp. There is a very rough direct route 
from here to Mostar, available only in summer, by which supplies could be obtained. At Dnopoljo our guide's knowledge gave out, and we had to get a boy to show us the way, which turned out to be a very bad one indeed. We climbed the Crnagora Range, which is here, as almost everywhere, covered with fine woods. Unfortunately, we did so in cold driving rain, and, though this time we had our macintoshes ready, our pleasure was spoilt. Towards the end of our descent on the further side we caught sight of the white buildings of Lakat gendarmerie barracks, where we arrived at half-past six, the ride from Ruiste having occupied exactly five hours.

The Lakat barrack is peculiarly roomy, the stranger's room being a separate building, and almost châlet-like with its broad wooden verandah. As we were expected, a good fire was burning, and when we had got rid of our riding-gear we were glad to sit down to an excellent meal. We had reason to congratulate ourselves on being safely housed, for the wind (scirocco) soon increased to a regular gale. Before morning it took the roof of one of the out-buildings bodily off, and deposited it upside down thirty yards away. Wind and rain continued all next day, and made it impossible to venture out.

I had hoped to have a chance in the Crnagora of shooting a balzhahn, or cock capercailzie, in the 
act of going through the extraordinary performances with which he summons his harem. It is only at this season that this wary bird can be stalked, and the doing so is considered on the Continent a feat of venery equal to shooting a royal or a chamois. But my pains were thrown away, for the forest-keeper reported that he had not heard a single cock that month, a statement which was confirmed by an officer of Bohemian Rifles, who had the patience to spend two nights, one before and one after our arrival, at a wood-cutter's hut on the hill, but in vain. There certainly are capercailzie about, but very few, and no doubt most of them fall victims to the numerous vermin, especially martens. On one occasion, going through the Velez woods with a Turk preceding me, he pointed upwards and said, "Tetrieb." Of course the bird was gone among the thickly ranked tree-stems; but he persisted that it was a capercailzie, and a black one, i.e. a cock. I only saw one bird myself-also in the Velez, as will be hereafter narrated.

The Velez at this point consists of one line of sheer precipices. In five miles there is only one place where a good cragsman can surmount it. At the foot of the precipices, and of the gentle slopes at each end, are magnificent woods, extending from ten to twelve miles-beech below and fir above, extending for thousands and thousands of 
acres. Yet all these woods are waterless. The Velez woods are only separated by a few rods of open ground from those of the Crnagora, at whose south-east angle the Lakat barrack stands. Before it stretches the Nevesinjskopolje, mostly cultivated, but just here a mass of low hazel covert. The monotony of the plain is only broken by a few villages and by cemeteries, those of the Bogumilites being the most numerous and conspicuous. In the nearest one to Lakat stands a huge cross, on the upper limb of which the face of the deceased is portrayed. The long drooping moustache is very distinct and characteristic. Crescents and other conventional ornaments decorate the rest of the stone. Near Nevesinje is another conspicuous stone, with very plainly sculptured equestrian figures.

My attention these first days was more bestowed on the woodlands. Lakat itself lies almost directly behind Mostar-the Velez of course intervening. Behind it the Crnagora Range, which owes its name of Black Mountain to the fact of its upper part being covered with fir woods, runs for some seven miles, its culminating point being 4300 feet. My first object was to examine this; so, taking my gun, I started off, followed by the two dachshunds. The entire range consists of a succession of cupshaped hollows (karstlöcher). On the lower ground they are pretty enough, being covered with 
rich grass and every description of wild flower, but on the upper slopes, with their tangle of fallen fir trees, bushes, and rocks, they make locomotion very difficult and, in anything like a straight line, impossible.

In these upper hollows the snow was lying everywhere, but it was nowhere marked by the footprints of game. Indeed, the hill seemed to be almost gameless, the dogs only finding a couple of hares on the lower ground and a fox on the upper. The wild desolation of the pine wood, with its masses of rock and fallen trees, seemed ideal bear ground; and indeed there are always bears in the Crnagora, but on this day I saw nothing. The silence was unbroken throughout my ramble, save once when a great tree, some fifty yards away, came down with an echoing crash. As I have before said, the nature of the ground made it impossible to keep a straight course, and I could easily have lost my way had it not been for the sun, which was shining brightly, and consequently enabled me to direct my steps to the barrack, which I reached after a five hours' walk. Half a mile from home I passed the decaying remains of a wolf hanging to a tree, and a few days later I saw another lying by the wood-cutter's hut before referred to. Both had fallen to the keeper's rifle, and as one had contained four young ones, the government reward was worth a fair sum to him. 
On another afternoon I sallied out in the hope of reaching the bottom of the tremendous precipices which here bound the Botin (6000 feet), the highest point of the Velez, but, as a matter of fact, I went some miles too much to my left. An hour's walk brought me into a dense beech wood, and then, by a desperate scramble, I reached a long ridge, which I followed. The snow became thicker and thicker, and was covered in places by the old droppings of chamois, now gone higher up. At last I got right into a snow-field underlying the splendid trees. I walked for half an hour on snow a couple of feet deep, but so hard that I did not sink in at all. Of fresh game tracks I saw none, but one a couple of days old, which I took to be that of a galloping roebuck. I got to know those tracks better soon as those of chamois. At another place a small bear had been whetting his claws on a tree-trunk, but so long ago that his footprints had melted away. The size of the bear is easily estimated from the height to which the marks reach, as they stand up to embrace the trunk. Not long afterwards, on this very ridge, I saw some I could not reach on tiptoe.

I descended this ridge on the opposite side into a valley I was afterwards fated to know well. At its lower end a streamlet (strange sight here) rau purling over the stones. I followed a wood 
path parallel to this, which soon took me to the open plain and thence home.

A walk in these woods is a sad one for a lover of trees. Were it not that the Slav peasant is much too lazy, one would think he uses his axe for the pleasure of destroying; and indeed he rarely passes a fine tree without giving it a slash. Everywhere are felled trees lying rotting, some of enormous size, but what is worse is that they are always cut some four to six feet from the ground. In the same way one comes across dozens of young trees cut down and left, apparently from laziness. Even on a summer day the axe is at work everywhere, contrary to all our ideas; but perhaps firewood can be as well cut in summer. Of course, there are no funds for the proper conservation of these forests; but, with wood at famine prices in Mostar, one would think it would pay the Government to arrange some sort of rude lift to get it up the Velez, with the view of shooting it down the opposite side. The worst sight of all are numerous pine trees standing with the heart burnt out. It may be said that as a rule these were previously decayed, but, though this is often the case, it is equally often the case that adjoining sound trees are so destroyed. Besides, the sound pines (lučca) in other districts are mostly damaged by fire. The simple fact is that the Austrian Forest 
Department has so far been unable to root out the bad old Turkish ways, which ruined the woods round Mostar.

The only sport I had during my stay at Lakat, which lasted a fortnight, was a bear-drive in the Crnagora, the forester having reported three. In the first beat there was one, but owing to paucity of guns he escaped unshot at. All that passed the guns in two beats were a couple of roe-deer.

Having now decided to spend the summer in the Herzegovinian hills, we naturally were busily employed, whilst our camp gear was on the way, in selecting a site for camp. We finally settled on the valley I have previously referred to. The stream was already dried up, it being purely a winter affair, formed by the (subterraneous) overflow of a lakelet a quarter of a mile further up. So the villagers do not get very much use of their mills, and, as a matter of fact, generally go to the Upper Narenta to grind their corn. The little lake, which I had not even noticed the first time I struck the valley, gives the place its name of Jezero. At the western end of the valley, which, by the way, is 3450 feet above sea-level, woods are piled on woods up to the (then) extensive snow-fields which run along the bottom of the Velez precipices. (By October the snow was practically all gone.) At the northwest corner of the valley, between three noble 
beeches, the tent was pitched, and thirty paces behind it I had a hut built for our servant. The tent looked down the valley, and behind the trees which closed this in at its lower end rose the bare peaks of the Cervan Range, then still streaked with snow. The first time we visited the spot "Waldmann," disappearing in the wood, gave tongue, and directly afterwards a doe broke within twenty yards of me. He had not seen one for two good years, and he was not fated to see another; for, being accidentally locked out one night at Lakat, the poor old fellow was so terribly mauled by a wolf that he died next day. So we went but sadly into camp. 


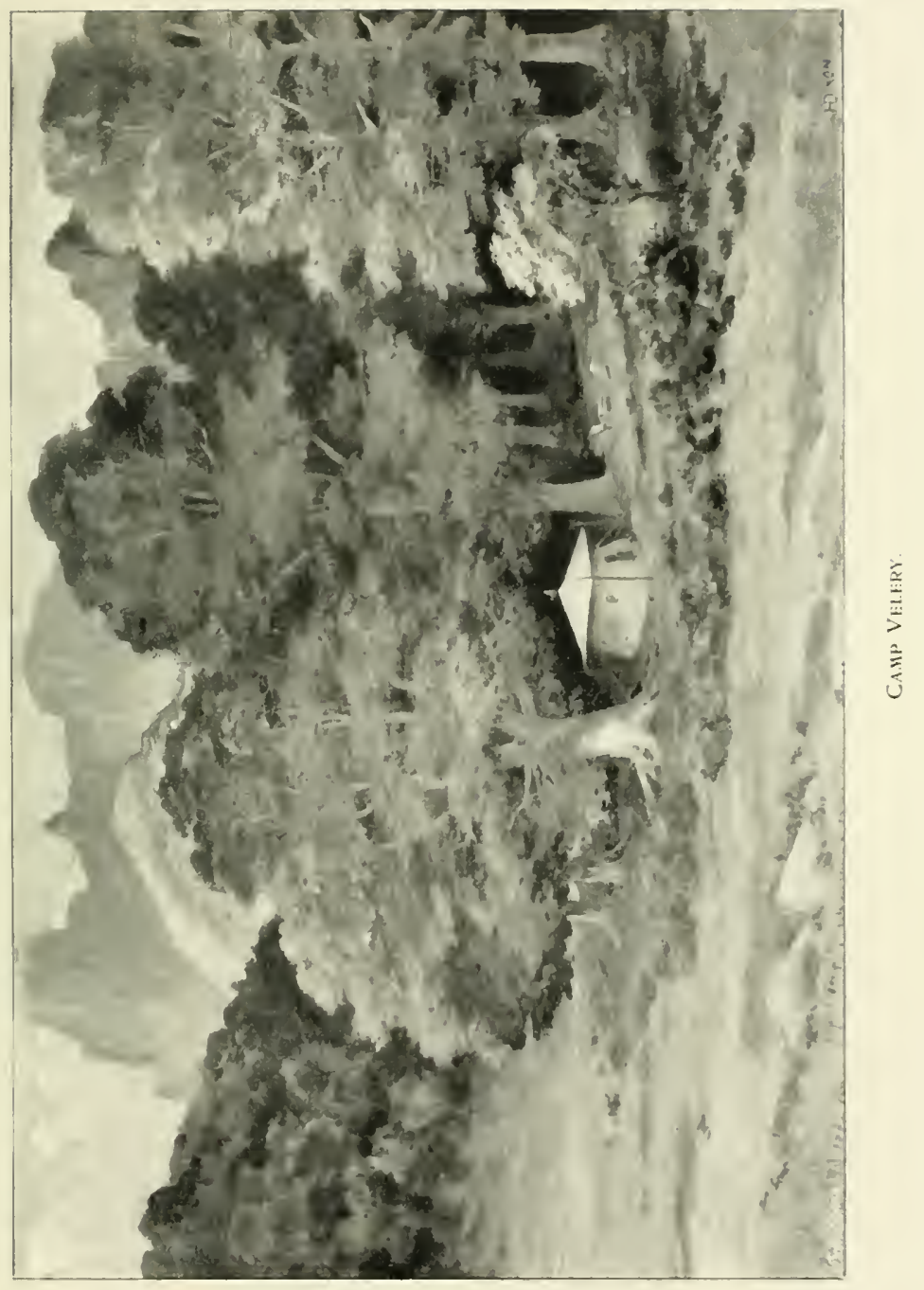





\section{CHAPTER XXVI.}

WE had now to learn what a vast difference, from a camping point of view, there is between Dalmatia and the Herzegovina-or I should rather say the Velez, for after we left this range things went much more pleasantly. It is true that there is one point of resemblance, and that is the difficulty of getting a camp site with good water-that is to say, away from the Narenta and its tributaries. Wood, such a difficulty in Dalmatia, is nome here. The sport of the Herzegovina is, of course, far superior to that of Dalmatia.

It is, however, in the intercourse with the natives in which the principal difference lies. A more idle, disobliging lot than those at Lakat it would be hard to find. They have a very good idea of fleecing the foreigner, and if he will not be fleeced he will not be served. For instance, I knew that the tariff for a messenger to Nevesinje was half a florin. I, of course, always had to pay double that. On one occasion I wanted to rido into Nevesinje, the usual charge for a horse for 
a day being ninety kreutzer. I was asked three florins, and on my objecting I was refused the horse, and had to walk. This is the peculiarity of the race. If they cannot get an exorbitant profit they will have none at all, and, as in this case, keep their beasts idle instead of letting them earn what is to them a considerable sum of money. The truth is, that they have no wants; their flocks and herds, with a little mild agriculture, feed and clothe them; and, excepting tobacco and coffee for both religions, and a little wine for the Christians, they have no Iuxuries. Indeed, I met many Turkish peasants who did not even smoke. Competition is wanted to smarten them up, and this they seem unlikely to get, the Austrian attempt at colonization on the Ivan Pass near Sarajevo having failed. This was only to be expected, as the selected colonists had no capital, although the Government was prepared to support them sufficiently liberally. It is $\mathrm{my}$ opinion that a good deal more might be done in this way.

Our great trouble, then, in this camp were the natives. Not that they intruded themselves upon us-on the contrary, they never came near us; so that for the time the lessons I had taken the trouble to take in the language of the country were thrown away. We had calculated on their bringing eggs, fowls, and milk for sale, but they 
were much too indolent. These things were only to be had by sending for them, and then at double prices. Milk certainly we got from the shepherdesses for a time, and then they said "a man" had forbidden it. I never could learn who our mysterious boycotter was, but came to the conclusion that my presence interfered with somebody's poaching operations. As for getting any help from the peasantry, as we had done in Dalmatia, that was quite impossible. It is true one of them built us a hut, which, primarily intended for our servant to sleep in, afterwards. was used solely as a kitchen; but it was not very well done, and we had to pay pretty dearly for it.

One improvement in our camps this year was a camp-stove. This came all the way from Illinois, U.S.A., and simply was the blessing of our lives. No more trouble of camp fires as last year, and no more tears called forth by pungent wood-smoke. We could cook half a dozen things at once, or even bake bread, with no trouble at all; and we never grudged the trouble and expense to which we had been put getting it all that distance. A propos of baking, I shall never forget how I laughed when $\mathrm{E}$ found a dachshund curled up on the cloth which covered the dough which had been put down to rise. I am afraid the fact that he exactly fitted the pan did not save him from 
punishment. Another improvement was in the tent itself, for, a first experience proving that the tent was a little inclined in wet weather to drop at the windows, we had some stout dungaree made up about four yards square, and used it as an outer fly. As it was dark blue in colour (at first, but soon fading to butcher blue), the effect was decidedly picturesque. We also managed to get two very good camp beds from Vienna.

Servants were a terrible trouble. Our first stayed twenty-four hours; the second (at fancy wages) a month, and then left just as he was getting useful. Certainly he could not stay, for, being a small landowner near Nevesinje, he had his crops to look after. Not liking the looks of the next two candidates, we did without one for a time, and did very well, although of course we had to pay often and highly for messengers to fetch stores from the town. When we moved camp, however, we were lucky enough to get exactly the man we wanted. One thing we did miss, and that was the sea-bathing we had enjoyed so much in Dalmatia. Now our collapsible tub came in useful, but the water had to be carried over a furlong from the Jezero. This water, too, was a terrible trouble. At first it was all right, but as the lakelet dried up it got worse. There was one awful period when the water just covered the three wells sunk in the 
bed, and the cattle were in it all day. Then it shrunk into the wells altogether, and was once more good. But at the last the water gave out at Lakat; people were removing ours by horseloads all day long, and the wells were only clear at daybreak. Of course our filter went out of order just at the wrong moment.

Our "servants," then, being hardly worthy of being included, the personnel of our expedition was the same as in Dalmatia, with the exception of my poor old Waldmann. Later on his place was taken by his son and daughter, and finally we also added three English beagles to our pack. Another feature of the camp was "Bridget M. Malone," a white chicken, which, arriving as one of a batch intended for the kitchen, singled herself out by her familiar, not to say impudent, manners. For the information of other fowls, I may say that her habits of getting on our chairs and shoulders, etc., saved, and still save, her life. A principal article of her diet were the frequent "pollywogs" which were brought up in our water, and to see her fishing in a bucket was a sight for gods and men. Water-beetles also she did not despise, nor small newts, but she drew the line at the adult eft. Added to which she would steal anything about the camp, and E- - spent an appreciable portion of her day in chasing her. 
Although I am perhaps somewhat anticipating, I may here mention another and very agreeable feature of the Jezero camp, i.e. the number of visitors we had. From first to last I think the whole of the Nevesinje garrison visited us, and most of the ladies. On several occasions large parties came out and spent the day, and one officer brought out his tents and stayed a week. Then we had one or two short visits from friends in Mostar, and altogether the time was less dull for $\mathrm{E}$ - - than at our next camp.

Once the camp was comfortably settled, I proceeded to endeavour to locate the chamois, against whom I had promised myself an active campaign as soon as the season should open; and here it may perhaps be as well that I should give the reader some idea of the ground, which, being within my reach, I might reasonably expect to hunt. Assuming, first of all, that the main cliffs ran in a very roughly straight line, and the bulk of the ground below them was one moraine and mass of loose rocks and stones, I proceed to deal with any conspicuous natural features. First of all, beginning at the Nevesinje end, was the long ridge I have already spoken of. This ran right to and up the main cliff, which I believe might be scaled at this point, though $I$ always funked it, not seeing how I should get down again. About five furlongs further on the main cliff ran out in an elbow, and 
below it was another ridge, notorious even here for being bad going. As I had to give my own names to places, I called it the Mushroom Ridge, from a quaint-shaped rock upon it. Further on again the cliff ran out once more. Its extreme point, quite detached, was a curious rock, perhaps eight hundred feet high, and exactly the shape of a seated human figure. Readers familiar with the pictures of Mr. Rider Haggard's " Ghost Mountain "will know what I mean. This had a native name, Zeleni Pas (Green Dog, I suppose), and opposite its further end was a detached peak quite away from the main ridge and towards the plain, called the Velikigradac. The ground between this and the Mushroom Ridge was a mass of wildly chaotic rocks, which I called the Bad Lands. Opposite the Velikigradac, across a deep valley, was another peak, the Maligradac, from which another long ridge ran down to near my camp. Not a mile further on came the Botin peak, and nearly under it two deep valleys ran under the main cliff, like two $V$ 's, so $><$. I never went much further, the ground being desperately difficult and broken, and also a long way from camp.

Although I never, except on three occasions when I had friends with me and particularly wanted to see them, walked up to the cliffs without seeing chamois, I came to the conclusion that there were not many on the ground. I estimated 
them at about thirty, aud I believe correctly; but I am sure there are more above Smečanj. But altogether the Velez is not high-class chamois ground, even for the Herzegovina. Not to speak of the Divja Grabovica, where there are any quantity, and the Trebova district near Gacko, also a sanctuary, there are many more in the Zivindol and the Visočica.

On one occasion I followed the track of a large bear in the snow for over a mile, unfortunately without getting a view of him. I should have persevered till night had I been alone, but there were with me two officers of the Nevesinje garrison, whose time was limited.

On four occasions we heard one roaring at night within a comparatively short disiance of the tent-say two hundred yards. It may be remarked that their rutting season coincides with the first weeks of our camp life. About this time, too, a gendarmerie patrol shot one in the Crnagora, a magnificent beast, seven feet from nose to tail. I believe the gendarmerie are not supposed to be allowed to shoot, and they certainly should not be, if the desire of the Government to attract sportsmen from a distance is to be realized. In this case I naturally felt the more, having expended money and trouble to come here, and having the game shot away under my nose.

The fauna and flora of these hills would be very 
interesting to specialists; and, indeed, as will be seen hereafter, I met one here. To the larger animals I have already referred, and shall do so again to the bear, wolf, and chamois. Roedeer are not very plentiful, but there are a few. The finest roebuck head I ever saw in my life was shot in the Velez in '92, and for weight, length, span, and beauty would be hard to beat. Foxes I should say are rare-at least $I$ never heard one bark at night, and never saw but one. Badgers, wild cats, and martens are all to be found, the latter in considerable numbers. Hares only occur on the lower ground, and are not plentiful there. The list of larger mammals is completed by squirrels, red and black.

Vultures, eagles, and hawks abound, from the majestic lämmergeier downwards, and there are all sorts of owls in the woods. Capercailzie exist, but are not common. This, however, nearly completes the list-at all events, of birds of any size. Woodpeckers abound, but pigeons are not so common as might be supposed. I once saw a pair of hoopoes near camp ; they are common in the Nevesinjskopolje. I also saw a bee-eater once or twice, and once a widgeon, at the Lake. A pair of sandpipers occasionally frequented it also. In the mountain itself, besides the Falconida, there are blue-rocks, and the pretty wall-creeper, which might be taken for a large butterfly, so brilliant is 
its colouring, and so characteristic its method of settling on the face of the rock.

Of reptiles, there were, of course, plenty of frogs and lizards, but snakes were not common. Early in our stay I killed one close to the tent, but this was done out of consideration for female nerves, for it was only a common grass-snake. Later on I was glad to be able to despatch a good-sized horned viper, at the unusual elevation of five thousand feet, and, what is more, he was lying on the snow. These very poisonous snakes are the pest of the Balkan Peninsula, and are quite unmistakable, from the horn which grows upwards and forwards on the snout. During our stay a Turk was bitten by one at Nevesinje, and died the same day. A beagle of mine was bitten at this camp and another at the next, but probably both by common vipers, as they both recovered.

Of insects there are any quantity, but I am no entomologist. Grasshoppers of every sort and size, butterflies, moths, beetles, from great stag and antelope beetles downwards, flies, and creeping things innumerable, made themselves rather a nuisance. So, too, did the mosquitoes in July and August, possibly partly owing to the vicinity of the Jezero, but they are everywhere in these woods.

The flora of the Velez is very beautiful, and should prove most interesting to a botanist. When we first went into camp, the plains were 
covered with a tall white lily-like plant (Asphodilus albus), the leaves of which the natives harvest, I suppose for bedding for the cattle. All the Alpine flowers are represented on these hills, but what is perhaps more interesting are the many wild varieties of our garden flowers-primula, carnation, tulip, sweet-pea, and others, being represented. There is also a sort of dwarf tiger-lily of a crushedstrawberry colour. Orchids white and purple abound, but the yellow foxglove is a rarer flower, not, I am told, being found further west than this. Here it is plentiful. As the summer advanced the flowers, so to say, went up the hills, so that violets, anemones, and so forth, were obtainable near the summits months after they had disappeared below. For instance, the blue gentian was plentiful by the tent when first pitched, but soon it was not to be found under 5000 feet. The beeches were in full leaf down below when we first came, but the highest ones were not even green. Yet the leaves of these latter were more than half off before September was out. Some people say the edelweiss is to be found in the Velez, but I never could find it. It grows, however, in the Divja Grabovica district, but there the hills reach 6877 feet. The lily of the valley we found very plentiful, up to 5000 feet.

From the middle of July there were plenty of strawberries, not, however, equal in flavour to 
those of Switzerland, and later on raspberries. Their fate was mostly jam. On the upper edges of the woods, but only there, there is a profusion of the plant which we Monmouthshire folk call the whimberry, but which is known in other parts as the bilberry and the whortleberry, the last being in Devonshire abbreviated into "oert." The strange thing about these were that there were no berries. I only found one the whole summer, and feel pretty sure that, as a rule, it does not fruit.

Just by the camp I picked up a stone arrowhead. What old-time sportsman, I wonder, had discharged it, and at what quarry? Very likely at stag or boar, neither to be found here now. 


\section{CHAPTER XXVII.}

Nor long after our arrival I saw my first chamois, and, what is more, I saw some two days running. The first day it was a single buck that the dog moved on the Mushroom Ridge; and on the following day two chamois lying between this and the Long Ridge, which saw me first and made tracks. It was too early for chamois-shooting, so I contented myself with observing their habits and routes with a view to the future. On one occasion my wife expressed a wish to see one, and I was able to show her two within three hundred yards at the end of a short walk. I did this by taking her up a wood path which started near our tent and ended just below the Mushroom Rock. This was the quickest and easiest way to reach the cliffs.

A record of anything like all my successes and failures at the Velez chamois would be more than any reader would care to wade through, so I propose only to describe three days of the sport, those on which I got my first chamois, my first buck, and my first solitaire. I may also refer to some 
incidents of other days which possess independent interest.

At the time I went to the Velez I may say I was absolutely without any knowledge of chamoisshooting, or of the ground I was going to shoot. It is true I had, I may almost say accidentally, shot a chamois the previous January, as already related; but this had not added anything to my woodcraft, which was purely second-hand, and did not prove of the slightest use to me. Since then I have carefully read a well-known Austrian authority on the subject; and, though I must agree with almost everything he says, * I cannot conceive any of it being useful to a beginner. Another disadvantage, or what some might consider so, lay in the fact that I invariably went alone, and consequently was unable to avail myself of local knowledge as to the resort of the game, and that very important matter local wind and currents of air. I did so partly from the feeling that I have always had that the essence of sport is to pit one's self against one's game; but also much from the knowledge that stalking has never been practised in this country (was said, indeed, to be impossible), and therefore I should

* He says the hollow pointed bullet is unsportsman-like, a dictum with which no Englishman will agree. The title of the book is "Das Waidwerk in Oesterreich," but I forget the writer's name. 
have had great difficulty in getting a native to do what I wanted. Still, not to take undue credit to myself, I must remind the reader that I had plenty of time to learn my ground, and so on. As will appear hereafter, this was not the case in the Visocica, nor was I near enough to the chamois ground, so there I descended to native hunters. and native methods like everybody else. Thus I certainly learnt a good deal about that ground also, which learning I hope to apply by stalking there some day.

I venture to think, therefore, that no one can be in a better position than I to speak of the merits of chamois-stalking as a sport, and I have no hesitation in placing it, when practised in this way, alone, very high among field sports. The little black shiny horns may not be in themselves. a trophy of great value, or compare in beauty with many others; but the sportsman's eye will always rest lovingly on them as he reflects that each pair has been obtained at the risk of life and limb-at least, I can assure him that he must be prepared to do this in the Velez cliffs. Strange to say, before I began chamois-shooting I imagined my head was not strong enough for cliff-work, but I was able to shake off this feeling at once, and was hardly ever inconvenienced by it.*

* Since writing these words I have come across some remarks by another writer, from which I gather that this is a very usual cxperience. 
I was very much handicapped by the want of a good telescope, being thrown back on the use of a pair of foreign binoculars, so indifferent that they did not show the horns at a couple of hundred yards. On a good many occasions, too, I regretted not having a rifle, for I lost several chances at about 200 yards, which I feel sure I should not have missed with an express. Although no friend to telescope sights and fancy ranges, I must admit that 150 yards is too short a distance to be restricted to, and in such stony ground it requires very delicate stalking to "get in " to that distance.

At last the time came to commence operations. The waters of disappointment are a beverage the taste of which I fancy is pretty familiar to every chamois-hunter, but never, I think, did I drain the dregs thereof more thoroughly than on my first day in the Velez. As I have said, the main range ran, roughly speaking, north and south, so I naturally regulated my approach so as to strike the lee side of the ground and work to windward. On the morning of which I am about to speak a fresh northerly wind was blowing, so I made for the southern end of my ground. I have never been a sportsman of the peep-of-day school, and somehow the fact does not seem to have lost me a great deal of sport. One thing I am sure of, and that is that the man who goes through the routine of tub and breakfast comfortably before 
starting is equal to twice as much climbing and walking as he who has started before dawn, half rested and not half fed. On this occasion it was nearer nine than eight before I started, and ere long I had left some thousand feet of forest below me, my objective being the Long Ridge, an excellent spying-point with this wind.

Just before I reached the last climb, my dachshund Rex (a mute dog is, of course, only admissible at this sort of work), whom I had pushed up the rocks in front of me, flushed a bird, which rose heavily into a small fir and there remained, uttering a continual guck! guck! of alarm. It was a hen capercailzie, and, being sacred by virtue of her sex, she of course remained some minutes within twenty yards whilst I examined her with the glass. At last I moved forward, and then only did she take wing, showing the characteristic semicircular tail, and I heard her alight in a tall tree some fifty yards below. I stopped to let the dog try round in the hopes of seeing something of her young, but in vain.

Meanwhile I had gradually been becoming aware of a very annoying fact, namely, that the wind had chopped completely round, leaving me in the unpleasant position of being near the southern end of my ground with a southerly breeze, and consequently with the certainty that when I began work my wind must go on before 
me. The wind was always playing me these little tricks in the Velez. Still, I hadn't come all this way for nothing. There was a little ground to windward of me; and I turned across a furlong of bare and broken rocks to spy a shallow valley beyond. As I lay on the cliff, glass in hand, I thought I heard a movement in the legföhren (Pinus Mughus), which formed the centre of the snowfield before me, but could see nothing. Presently, on turning my eyes once more from the valley, I caught sight of two chamois-a good buck and a smaller one-nearly at the top of the snowfield. The smaller one lay down, but I was not to be deceived by that manœuvre into believing he was not quite as fully on the watch as his friend. The matter seemed pretty hopeless, but I determined to try the stalk. To the right (i.e. leeward) of the two was a buttress of rock which afforded a good approach, but the real question was the highly improbable one of their remaining quiescent on losing sight of me. The only chance in my favour was the dog-all animals being singularly curious with regard to one; so I left him and my rucksack to attract their attention, and shambled off in a stooping position across the open. One last glimpse I had-neither had moved-and then the big rock hid us from one another's view. I struck a long snow-slope and went briskly along it; then followed a ridge 
of rocks, and then snow up to the shoulder of the rock whence I must shoot. A dozen yards from that edge I left my alpenstock, and commenced the final crawl. Hardly had I began that, when I felt a tickling sensation at the back of my head. I looked round. As I had feared, the wind had chopped right round again. The game was up, unless, indeed, some unknown draught of air among the rocks might yet draw the taint to one side of the game.

"Whew! whew!" As I had expected, two hissing whistles greeted the appearance of my head above the skyline. Having had the wind, or perhaps, indeed, suspicious of my disappearance, the artful animals had withdrawn to the far side of the snowfield-say some four hundred yardsand now proceeded to put a still further distance between us. This time, however, they had overreached themselves, and arrived at the base of a cliff not even they could surmount. They had, therefore, to return to a couloir between us, and thence work up the face of the pine-covered rocks. It soon became obvious to me that their course must bring them considerably nearer to me-not, indeed, within fair range of my weapon, but I had lost my temper, and determined to take the shot. So I threw myself down and waited. In a fow seconds more they must disappear. Bang! A mad dash downwards showed the bullet had gone 
high, but directly afterwards they turned and crossed a snow-patch above. Bang! again, and the snow flies to the right of the big buck. They are gone, and nothing remains but to retrace my footsteps (measuring my length over an unseen crevasse en route) to where the dog's eye reproachfully inquires, "What! no game?"

Never mind, doggie, the day is young yet. Better luck next time. I sit down in the bright sunshine, pleasant up here among the snow, to eat my lunch. By the time my pipe is under way I feel decidedly better; and, fortunately, the wind seems to be fixed once more in its original quarter. "The great charm of chamois-shooting," I reflect, whilst letting my eyes rove over a wide panorama of nearly a third of the Herzegovina and a bit of Montenegro in the background, "consists in the fact that it brings one so entirely alone together with Nature at her wildest and most solitary- Hullo! what was that?" A bugle call rings out above me, followed by shouts. A company of the Jïgers from Nevesinje are doing a little Alpine work on the fairly level top of the range which slopes gradually down to their garrison. So much the better, the chamois can't stand that. As I so reflect, a buck appears against the sky-line-a noble sight. I turn my head for a minute, and he has disappeared, no doubt down the tremendous couloir to the big snowfield 
beyond the Long Ridge. What a noise those fellows are making up there! Still, they are a thousand feet above me, so I shall take the trouble to climb up to the top of the Long Ridge. 'Twenty minutes do it; and there I leave dog, stick, and rucksack, and crawl warily to the legführen-covered edge. Lying down at full length, I proceed to get out my glass, but it is hardly wanted. There on the snow, a couple of hundred yards from the base of my cliff, are two bucks, without doubt the same which I saw before lunch. But how to get at them? The cliff I am on is sheer, and the couloir they descended when, as no doubt happened, the troops headed them back, is one I would not dare venture on. To my right the cliffs become lower, but are still impossible, and if they were not they are in full view. Even if I went right round I should be no better off, with some four or five hundred yards of open snow between me and them. Well, I must e'en lie here an hour or two and see what happens. As a matter of fact, I had not lain a quarter of an hour when-crash! The soldier who rolled that rock over in idle (and dangerous) play did me a good turn, anyway, for both sprung round and galloped towards me. Now I made my first bad mistake. I ought at all risks to have kept the glass on them, instead of which I bounded down the ridge to tako post at a saddle fifty yards lower down, where I thought 
they would pass. After lying quiet for some time and hearing nothing but a rolling stone, which the melting snow might have released, I saw my error, and went to the edge. Nothing in sight. I was deceived, then, when I thought $I$ heard a cough below. They must have turned sharp back and gone up the couloir again. This was my second, and what may be called an instructive, mistake. What business had I to assume, once I had lost sight of them, that they would go back to where they had just been disturbed? The assumption, indeed, was just as absurd as my previous one, that they would come up towards the place where an hour previonsly they had seen a man and been fired at. As a matter of fact, as I now know, I then had a chance second to none I got that whole season, and I muddled it in this way.

"Well," I thought, " the game's up now; and it's too late to think of looking for other's, whom the row above will probably have driven into the woods. I must give it up and go home." I tried the north side, but failed to get down there, so climbed up to the ridge again; and, partly glissading the snow-slopes, and partly scrambling down the rocks, descended at a fair pace, keeping nearly on the line of the main ridge. I did not pay much attention to the dog, but afterwards I recollected he continued to try about more than usual. My gun, of course, was slung over my shoulder. 
About a quarter of an hour after starting, I approached a cliff not more than a dozen feet high. I was thinking of nothing less than chamois, when all of a sudden there, not forty yards array, stood a buck. What ought I to have done? Certainly thrown away my stick, grabbed my gun, and taken the running shot, for my right barrel was loaded with buckshot. As it was I obeyed my first impulse, and squatted. Of courso I realized the buck had seen me, so, as soon as I was ready, I sprung to my left, in which direction his head had been turned. This brought me to a ten-foot cliff, down which I bundled anyhow, and now I stood on the main cliff. Surely he must pass this way. So he did, but that particular cliff happens to overhang, and he passed right under it unseen. Still, as I had calculated, he stopped at the end. It was a longish shot, but no longer than some I killed later on. Why-oh, why--was I in such a hurry that I could not stop to think how often I have missed by not remembering to sight low when the game, as in this case, was a long way below me? And at this elevation, too! At the shot he wheeled round, a clear proof the bullet had gone high. Reloading, I fired a futile snap shot as he plunged downwards through the beech scrub; and then I sat down to think over the mess I had made of this glorious opportunity. Thinking I should see him again, I reloaded once 
more, and as he stood whistling out on the snow I let him have my last two cartridges with the second sight up. As the first shot struck to his left he sprang to one side, but he failed to mark the next, nor did I see it. For a moment I had a vain hope that the bullet had found its billet, but presently he walked off calmly, and, as the glass showed, untouched. So there was nothing for it but to join the dog, who, unable to get down the rocks, was now waking the echoes, and who was soon off on the scent.

When I reached the snow I looked back. He had just reached the foot of the precipice at a place where I thought even he could not get up. (Later on, however, I saw the same two chamois ascend more than half of it, though it seemed quite sheer all the way up.) After a last look at us, he calmly ascended an imperceptible ridge on the face of the rock. Disturbed above and below, he had taken to the chamois' last refuge-the face of the sheer cliff. A minute later the dog took up a line across the snow, and, going to the place, I found the tracks of a second chamois going hard down towards the woods. This proved before all doubt that I had been concerned with the same two all the time, and had lost three chances-two by my own stupidity. When I reached home it was five o'clock, and as I drank my tea I reflected sadly on that other beverage to which I had been so freely treated that day-the waters of disappointment. 


\section{CHAPTER XXVIII.}

Whether I ever got another shot at those two chamois is doubtful; but certain it is that I only twice again saw two together, and then they disappeared. Possibly one was poached.

My next day made me amends for this failure. On one of his hunting days, we are told, $\mathrm{Mr}$. Jorrocks had cut himself in shaving, which he considered "werry symptomatic" of sport. On this principle (i.e. that the drawing of blood from the sportsman is likely to be followed by that of the game), I had every right to expect sport on this occasion. The day before, when tightening a tent-peg, I had brought the heavy mallet down on an unnoticed line, which had diverted the blow to my own physiognomy, almost entirely depriving my nose of its cuticle. Nevertheless, heedless of the risk of possible erysipelas from the combined effects of a broiling sun and the snow on my sore face (and, as a matter of fact, I did suffer very considerably), I started at eight o'clock, assuring my anxious spouse, who hated these solitary expeditions, that I should be back to 
lunch at one without fail. With this view I took nothing with me to eat or drink-nor even to smoke.

But the fates were against me, for, first of all, I missed the wood path I ought to have taken, which led up to the Velikigradać; and, secondly, having placed my rucksack on a fallen tree to sit on whilst waiting for the dog, who had gone off on the line of a roedeer, I left it there on rising, and had about half an hour's walk back for it. It was then I discovered that I had not brought my watch. Finally, I gained the object of my journey -the rocky saddle between Velikigradac and Zeleni Pas. In the snow-covered glen beyond there were often chamois. On this occasion it was vacant, but the field-glasses soon picked up three chamois right up at the bottom of the cliffs in the direction of the Botin. One lay down on a ledge of rock, and the other two went on, and took their quarters up in a curious place, behind the snow which formed a mass detached from the base of the cliff. They kept on coming out for a look, so I guessed they had my wind. In any case, I could not advance far without being seen. Things looked pretty blue, but still I must have a try. An approach from below is almost invariably a failure, but the unexpected is a big element in sport. Indeed, in this part the correct approach from above is all but impossible, for the chamois 
generally manage to have the cliffs at their back.

Twenty minutes brought me to a snow-filled hollow, where, at any rate, I was out of sight, but had I been detected getting down there? To approach to leeward I must go to my right. I had actually started to do so, when, happening to turn my head, I saw a herd of ten in full scamper behind me, on the lower slopes of the Zeleni Pas. This rock, as I have before said, is like a sitting human figure, and consequently sheer precipice to the front from the knees down. But the herd kept up the left side till they reached the grass ledge which represents the arms, and disappeared along it, looking exactly like mice in a wheatstack, which will give the reader some idea of the height of these cliffs. The Zeleni Pas was then quite unknown to me, but I thought it might be possible to follow where the herd had gone. A few minutes' thought convinced me that the three I had seen had formed part of this herd, and that as soon as they had lost sight of me they had scampered back to the others and gone with them. Consequently I changed my plans, and started up the snow-slope of the gully that led to the main precipice to my left front. When near its head, I secured the dog and stalked round to the spot where I had seen the three. Nothing to be seen, and a whistle failed to move anything. This 
proved the correctness of my theory, and I started off after the herd.

I have said that their route lay up and round the Zeleni Pas, and also that this cliff was barely united to the main hill. My first idea was to go right up the steep snow-slope to the cleft between it and the main hill, in the hope of getting a shot from thence. Fortunately, before I got halfway up I began to get very sick of the snow, and of the constant effort and care required, as a slip would have sent me right down to the end of the slope, and probably over the cliffs there too. I therefore decided to follow the herd exactly, though it seemed impossible that they would go up wind without keeping a good look-out in the rear for what had disturbed them. Once I struck the rocks, it was nice going; the grassy terraces were wide and easy, though I would not have gone to the edge and looked down for a trifle. Expecting to come on the game there, I secured the dog to my bag and started stalking. I went right round the conical peak without seeing anything, and just as I felt inclined to give up, the dog, who had got loose, joined me. Keeping him in to heel, I went a little further, and all at once I saw the herd on the big snowfield below me. Drawing back, I fastened the dog to my alpenstock with the sling of my gun, and wormed myself out on to a flat projecting rock. Yes, there they 
were, but only six of them, mostly lying on the snow, and all unsuspicious of my presence. They were, however, too far for my weapon, say three hundred yards off. But below me was another rock-ledge which must be a good deal nearer. I crawled back to the dog, and retired cautiously a hundred yards or so. There I left my gun, and started back, for the second time that day, for my rucksack. When I had got it I returned; and this time I was careful to tie the dog well. I had not long begun the crawl downwards, when I heard some stones rattle in front of me, and concluded the herd were coming back. Here again my geography was at fault; not even a chamois could come up there, and the stone was probably dislodged by the snow. After sitting expectant a quarter of an hour, I decided to advance again; and, to make a long story short, after a lot of hands-and-knees work, and a bad fright at a stone which looked just like a chamois staring at me, I reached the spot whence they should have been in view. Gone! I was not much frightened, though, for the broad snowfield to my right and front was spread out like a map before me. I continued the crawl, and presently picked them up. They had gone deeper, and were consequently nearer me.

Now I am on the very verge of the cliff. Two are coming towards me, but they look small. The third one from me is bigger and darker- 
in fact, the biggest of the herd. I think it is a good buck, and wish I had a telescope to make sure.* Shall I disregard the extra thirty yards? No distance can be harder to judge than one like this, down a sheer cliff. I adjust the sight, and as $I$ do so the big one rises and comes towards the others. In an instant my cap is on the rock, and the barrels rest on it. Now he stops, but only for a few seconds. Now again. This time I do not forget I am almost vertically above him, and sight between his knees. Bang! and he is kicking on the snow!

The herd had not the slightest idea whence the danger threatened, although I stood up, and the dog's yells might have guided them. After racing here and there, four of them moved slowly off up the snow. I was watching my quarry, and when I saw the poor beast stretched out stiff I returned to the dog, and attempted to get down to the snowfield. (I may here remark that this shot was heard in camp, and was fired at exactly two o'clock, so that the stalk must have taken about four hours. Such, however, is the fascination of the sport, that I never realized that I had been going for six hours on a slice of bread and butter and a cup of tea at 5.30 a.m.) After

* This was a beginner's error. The biggest chamois of a herd is never a buck, except, of course, in the rutting season. 


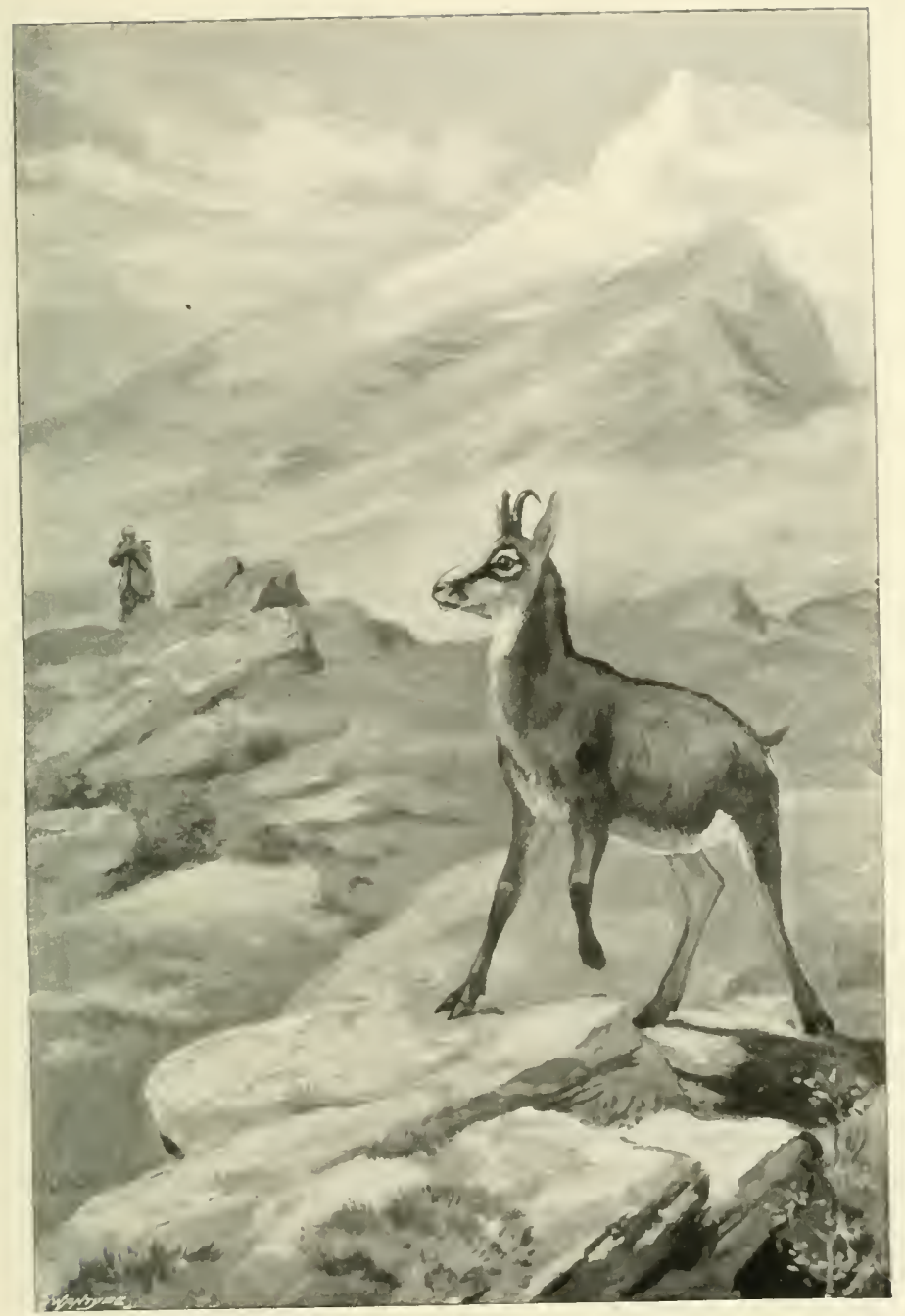

A SOIITAIRI. 

descending a shaly piece of cliff some furlong to my right, I came to a place where I thought I could get down; and did so, lifting the dog down, but he absolutely refused to come further. It certainly was very rotten stuff, though coarse grass grew on it; but a little further on I found out that to go on I must do the next forty feet in one, and that into the crevasse formed by the snow and the base of the cliff. So I clambered back, lifted the dog back again, and went back to the place whence I had fired. A glance showed the dead chamois, and another lying on some shale fifty yards from it. Of course I did not shoot; I could easily have had another after my first shot had I wished. Again my geography failed me; the Zeleni Pas is practicable at the angle nearest my camp, but, not knowing this then, I went right back round it again, but struck the snow-slope lower down. It was not a nice place. A ledge of rock, sloping out towards the crevasse it made with the snow, which was a score of feet deep, was so overhung that I could hardly get aloug it on hands and knees. But, thinking it must be lunch-time, I did go on, pushing gun and stick before me. At the end I could stand upright, so I tossed the dog up the seren-foot bank of frozen snow, cut steps for myself, and followed. A quarter of an hour's cautious descent of the steep snow-slope brought 
me to rock again, and thence easy slopes and rock enabled me to push on. Half an hour later I was in camp, but it was five o'clock, and my wife was in a pretty state of anxiety. The worst of it was that I had only an hour to eat and rest; and after some tea I started off again, accompanied by my better half and a man to bring down the game. This time we kept to the left. of the Zeleni Pas, and an hour and a quarter at very creditable lady's pace brought us to the big snowfield, where the dog, who had had the wind and run on, was already barking and tearing at the prostrate quarry. Alas! it was no buck, but next best to it, a very big old yeld doe, with eight-inch horns. Three-quarters of an hour brought her and us back to camp, and made up my day's work to exactly ten hours.

The death of my first buck was in every way a simpler matter. Meat being badly wanted in camp, and messengers impossible to get on account of the harvest, I started off one morning with the intention of trying my luck. At the same saddle where I began the previous time the dog put two chamois * out of the beech bushes, one of which gave a long standing shot. I think the bullet touched him, but it was probably only a graze. Anyhow, he went off. I worked straight along, past the Botin, and into a terrible country.

* Probably the two I made such a mess of my first day. 
As I was going along the hillside the dog roused and scattered a large herd, either in some beech bushes or on an adjoining patch of snow. One at least was left behind, and $\mathrm{I}$, who was now lying down, made him out to be a two-year-old buck. After a few minutes, the dog and main herd having disappeared in front, he made up his mind to clear out. Unfortunately for himself, he chose the route which passed by me. A running shot at seventy yards broke his shoulder. Nevertheless he made off downhill, accompanied by a kid. This gave me a bad moment, for I thought I had made a mistake about the sex; but, as a matter of fact, the little beast had got separated from its dam. A hundred yards off he lay down, and I crept in and gave him the coup de grace. I saw the others, followed by the dog no doubt, still going hard near the top of the hill, and it was an hour before the latter rejoined me. My first idea, after gralloching the buck, was to carry him home; but he was too heavy for this, so I had to set to work to skin and break him up. A long job it proved, and it was eight o'clock before I got my load of head and haunches back to camp. This, however, was principally owing to my attempting a short cut through the forest, which, as a matter of fact, would have been three times as long even if I had not lost my way, which I did. My wife's state of mind may be imagined. 
After this I was content to remain idle for a bit, or perhaps I should rather say I found sufficient employment in the work of camp without a servant. There is no doubt that there are drawbacks to the presence of a man in camp, but there are also advantages in the possession of a servant, especially in wet weather. This, however, we were not experiencing; indeed, we only had sixteen wet days in four months in this camp, and, after all, the freedom of the life and the novelty of doing for one's self are "the cream of the thing," as Josh Billings says of love-matches.

The next time I went out I had a couple of borrowed beagles with me, and my intention was to try for a roebuck. In this I was unsuccessful, but ere long I heard the hounds running high up, and guessed they had come on an outlying chamois. This, of course, was no good. Long before I got there he had gone up into the precipices; and this happened twice. At last I came towards that part of the hill where I had my first success. Below that snowfield lies a belt of beech wood, and I decided to try an approach this way, the dogs having disappeared. I had not got very far up when I came on the fairly fresh traces of a bear, and not a couple of minutes later $I$ heard the now familiar alarm-whistle of a chamois behind me. Turning round, I saw a large single one 
crossing the mass of wildly split and broken rocks which I called the Bad Lands. I threw myself down for the shot, but where he stood the background was so bad that I could not draw a bead. Just then he was obliging enough to move on a dozen yards, which brought him into sharp relief against a dark fir tree. Although the distance was really too great for my weapon, being well over two hundred yards, I was tempted to take the shot as my last chance for the day. I was very steady, and thought I heard the bullet tell. A crash followed, and when the smoke cleared he was gone.

After carrying out my original plan of taking a look into the snow-clad valley, which was blank, I went to the place, but found it such a mass of boulders, clefts, and crevices, that I could not hope to do anything that evening.

Next morning I mads my way to the spot with the dachshund, who, however, as I shall presently relate, proved useless in the search, and the upshot was that I conld find nothing, and probably must own to a miss. With a rifle it would have been a certainty.

Now followed a ludicrous bit of bad luck. Just before I reached the spot I heard a stone roll on the Velikigradać behind me, and, looking round, I saw a single chamois moving up it. In order to watch him more easily with the glass, I sat 
down and took off the spectacles, in which I always shoot, and laid them beside me on the grass. A minute later I heard the dog full cry in the wood below, and as he only throws his tongue when close on his game, I knew I must look out. My spectacles! Nowhere could I find them. The yapping increased; in vain I felt and looked at every tuft of grass and heather. At last, with a rattle, a chamois passed not a hundred yards away. I only saw his back, for where was the good of standing up without spectacles? Then, of course, I found them-not a foot from me; indeed, they were touching my knee. The dog having gone off in pursuit, I turned again to look for the first chamois, and was surprised to see a herd of six, a couple of hundred feet lower down, going along a rock wall with splendid bounds. The way they were going would enable me to cut them off; but the old vorgeiss* evidently realized this, for presently they turned back, and for half an hour or more I watched them moving and feeding unconcernedly on the side of the peak. Meanwhile, the dog being still absent, I occupied myself in an unavailing search for my buck of the evening before. At last the dog returned, and, although I had lost sight of the chamois, I decided to try the stalk, as I had a double chance there. I thought the single one

* Leading doe, who directs the movements of the herd. 
was lying in a patch of stunted beech high up, and the herd I knew must be somewhere there. An hour's climb up the lee side of the Grat brought me to the desired level. In the sun and ont of the wind the heat was very great; so I was glad to sit down to eat my lunch, and mature my plan of action. I had seen the chamois on the south side of the peak, and the wind was blowing freshly from them to me. But I calculated they would keep a sharp look-out that way, and decided to try the other side, although I was not sure if I could get round. It was a long and arduous climb, and finally ended in a place I did not like at all, for the cliff was some hundreds of feet sheer. I distinctly funked it, but could find no other way, so at last committed myself to a very jumpy chamois track along a fault of the rock, and partly on all fours-a hateful position, as it obliges one to look down-I got safely to the shoulder of the peak. Securing the dog, I crept stealthily forwards, but, alas! only to catch sight of a chamois to leeward, and directly afterwards of three more making off through the beeches. Still hoping for the single one, I went back and loosed the dog, who, after following the herd some way, tried the whole ground in vain. The wily beast had evidently gone clean off at first; and as for the others, all these hours' work had been wasted by a dozen yards. 
I had always imagined this Grat could be descended on the camp side; and so it proved, though it cost the dachshund a fifteen-foot tumble. But he wasn't hurt, for five minutes afterwards he was off full cry through the wood, very likely after the buck we had sought in vain. I, however, saw nothing. 


\section{CHAPTER XXIX.}

I DID not go up to the hill again for some time, and my next day was only noteworthy for the number-fifteen-of chamois which I saw. The dog rather spoilt matters, being very disobedient. I admit a dog is a doubtful advantage on these occasions, but still he is company. This day he first winded and moved one herd (six) over the cliff jutting out above the Mushroom Rock; and when I commenced to go round this on a grass ledge, he picked up another fresh scent, and though I hurried on, it was only to see (as I thought) some of the same herd in full flight the other side. I imagined them to have crossed the cliff whilst I was coming round it. I continued to move along the base of the cliff towards the scene of my first success; and presently a doe and kid came down and passed within fifty yards of me. Of course I would not fire. A furlong further on I lay down behind a beech bush, and presently I saw twelve chamois galloping along a gallery in the face of the rock, hundreds of feet above me. They crossed the top of the snowfield, and 
by another gallery reached the Zeleni Pas, and disappeared round it. Not long after I heard some animal panting and rattling the shale behind, and, thinking only of the dog, I whistled. To my disgust a buck dashed past, never pausing till out of shot. I then ate my lunch; and not till nearly an hour later did the dog come back to me, proving that he had followed the herd along those dizzy heights. After reading him a lecture, I considered the position. In spite of bad wind I decided to follow the herd, and found a place where, with a stiffish climb, I could get up the hill. The Zeleni Pas is certainly the best place in the neighbourhood for an approach from above, but on this occasion, when I reached its outer corner, it seemed hopeless, for there was a strong wind dead behind me. Securing the dog, I kept on close to the base of the cliff, and presently saw a chamois. Luckily there is a flaw of wind here, which blows down between this peak and the main cliff. This served me well, and I crept to a large rock, from whence I had a good view. There they all were, but too far for a shot. They were mostly small beasts and does, but there was one fair herd buck. I lay and watched them for a long time. Certainly they are the most timorous of animals. They were feeding on a shaly slope, and every time one dislodged a stone they all started; nor did they begin to feed again till 


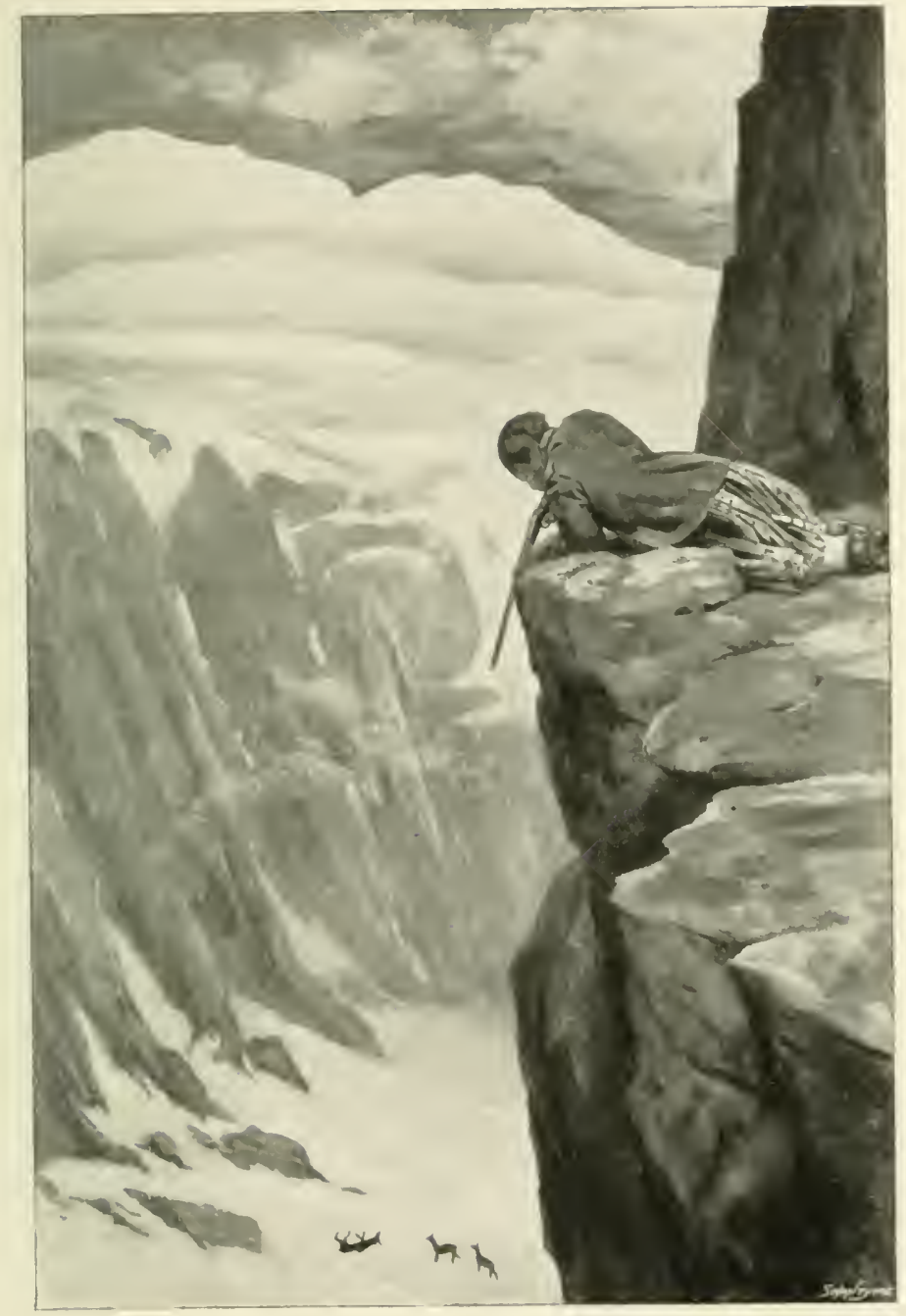

FIRST CHAHOHS OF THF SFANOS 

they had reconnoitred in every direction. One large beast, probably the old vorgeiss, was very suspicious, and on one occasion stared at me for several minutes. As it happened, she just caught me with the glass up, and there I had to keep it till my arm ached. At last she looked away, and I ducked behind the rock. Finally she came a few yards nearer, the others following. I waited another half-hour till the buck was within fair range, and dropped him.

This was all very well ; but I had been chamoisshooting nearly a month, and yet could not show a really good buck's head. As is well known to sportsmen, the good bucks never consort with the herds except in the rutting season; and the best of them go quite alone, from which habit they derive the name of solitaire. According to their habitat, they are called gratbock, in other words, a buck that lives among the cliffs, and latschenbock, one which lies in the woods nearest the snow. Old foresters will assure you that this distinction divides two totally different varieties of animal, which, of course, is not the case, though the chamois that haunt the woods (and there are herds that have this habit) are larger and finer. than those of the rocks. This, however, proves nothing; nor is the distinction so marked as it is between those of different districts. Greatly superior as is the Swiss gïms to the izzard of the 
Pyrenees, it is surpassed in weight and horn measurement by those of Austria, while, again, these must yield to the noble bucks of Montenegro, Herzegovina, and the Caucasus. Like the red deer, the further east it is found the bigger it is.

On the day of which I am about to speak I decided to try the neighbourhood of the Botin, and especially the two valleys below it. It was a very hot morning when I left camp a little before nine. My way lay through thick forest disposed in ridge after ridge, many of them covered with dense young beeches. After less than an hour of this, I struck a wood path at which I had been aiming. This, however, only went a short way in my direction; so presently I left it, crossed another ridge and a large open glade, and struck yet another path. I followed this till I began to feel that my breakfast had been of the slightest, so sat down and discussed my lunch. The post-prandial pipe followed this, and between the puffs I thought I heard a bear roar in the forest in front. Perhaps the wish was father to the thought; at any rate, I saw no sign of him afterwards, nor have I ever heard one on another occasion except at night. Roar, perhaps, is too fine a name to give the sound, which more resembles that of a cross-cut saw, but only continues a second or two, ending like a deep cough. 
Ten minutes after lunch I had to leave this path too, and now began a most tedious piece of work. A couple of ridges crossed, I had to face a slope where I could only get along by pulling myself up by the young trees. This surmounted, I found myself confronted by sheer cliff, which I turned by bearing to the right. Fifty feet higher I came to a cave which looked like a bear's gaura, and the dog hastened into it. When I reached it I found it thickly carpeted with chamois-droppings. They are fond of such places to sleep in. The old latschenbock who probably used it was, however, nowhere about. To make a long story short, it took me over an hour to do a mile or less, but finally a succession of wild rock and tangled beech thicket, ending in a hands-and-knees climb, brought me exactly where I wanted to get.

The two valleys were in front of me. Likely places for chamois, no doubt, but a weary climb on the off-chance. During the earlier stages of the ascent $I$ had several looks into the right-hand valley with the glass, but could see nothing. I thought the other was my best chance, and steered for a brêche which should command it. After crossing a snow-slope, which had been my landmark, I called the dog in close. At the top of another snow-slope I tied him to my rucksack, and, as I was within fifty yards, I left my alpenstock there too. Two or three minutes brought me to 
the brêche. Alas! it was blocked at the far end by a mass of fallen rocks. Well, I hadn't climbed up here to be beaten now, and a look into the valley I was going to have. Slinging my rifle, I tackled the rock to the right on hands and knees; but it was only to find other and harder rocks beyond. My blood was up now, and, thinking to myself that I must find some other way down, I wriggled over a rounded peak without either hand. or foot hold, with a drop beneath that I wouldn't have looked down for something. Another minute and I was peering into the valley, which I soon saw was utterly devoid of life. The next question was to get back. It could clearly only be done by a climb to the right, where the rocks were more broken. Five minutes did it, and then I had a look into the other valley, not without the reflection that what I had not already seen there must have seen me. Of course there was nothing.

A bad place caused me to keep right out towards the valley here, and just as I was about to turn to descend towards the dog, crash! down went a loose stone, and a big single chamois bounded out of the rocks not fifty yards away. Mr. Buxton, in "Short Stalks," makes the pertinent reflection that man is the noisiest of animals, and as a rule this is true; but he can hardly have been thinking of a chamois. I will cheerfully back myself to make a great deal less noise moving than. 
the most artful old buck living. Except on a snowfield, they invariably seem to select loose stones to tread on, and I have hardly ever been out without my attention being attracted to some of them in this manner.

In the very first days of one's chamois-shooting, one takes a running shot like this; misses, of course; and the game goes on for a week. I had already learnt better. During that first mad rush I had dropped on my knee and cocked my gun, and my finger was on the upper leaf of the backsight in case it should be prolonged. But it was not; on a peak about a hundred yards off he stopped and looked back. He must have stopped longer than usual, too, for I remember that, having cocked my favourite left barrel, I pressed the right trigger and took the weapon down to see what was up. Probably my doubledup aiming position puzzled him; perhaps it was because he had never seen a man in a kilt before. Very little time, however, was lost before the report rang out and he was down; down, nevertheless, to be up in a second, long before I had reloaded. But I judged that the first downward leap ended in another fall. Directly afterwards he dashed down on to the loug snow-slope, but scarcely had he struck it when his wounded shoulder gave, and he rolled anyhow down the next hundred yards, staining the snow with blood. 
Then he struck a reef of rock. Whether his impetus or an attempt to rise carried him on I cannot say, but he clattered over it and shot down a second snow-slope nearly as long as the first, and finally brought up against some more rock. I watched him a minute or two longer, and then he lowered his head. Little doubt of finding him now; so I turned back to seek the dog. It did not take me long to get back then, and then I made for a point where I imagined it would be possible to get down. But, in the first place, the getting there involved rather a nasty descent, which the dog declined; and, secondly, when I got to my spot I found it quite impossible. Nor could I even get a look at my game without a risky climb. There was nothing for it but to go round the cliff to my right, a proceeding which a grass terrace facilitated. Nothing is more convenient for the chamois-hunter than these same terraces, as long as he keeps away from the edge and does not look down; but one must know them, or else at the end of half an hour one comes to a fault in the rock which involves going back, perhaps to where one started from. It proved so in this case, but the place was not so bad but that I could negotiate it by a flat crawl, pushing my rifle and stick before me, and then all was plain sailing. At this stage I was joined by the 
dog, who had gone back and got round. He soon commenced to draw on the scent of the game, and long before I could get to him I heard him growling and pulling at the body.

As the reader will recollect, I had had neither the time nor opportunity to use the glass, consequently there must always be an element of doubt as to the exact nature of my quarry. Still, the fact that it was a large dark-coloured beast, and, above all, lying alone, went a long way to prove it to be a good buck. One last scramble down a clitter of rocks (as they say on Dartmoor), and, crossing the snow, I was beside the animal, which had scarcely, if at all, moved from where I had last seen it.

My doubts were soon set at rest; it was a solitaire. The horns were not very fine (I easily beat them afterwards), but they were well ringed at the base; and by the teeth, one of which was missing, I judged him to be seven or eight years old, if not more. Although the chamois is said to attain the age of a quarter of a century or even more, it is very rarely that the horns exceed ten inches. One wonderful pair I saw in this country was not only longer than this, but the span between the curves was so great, and the outward curve of the tips such, that they looked more like those of a wild goat. Only two or three Herzegovinian sportsmen can show horns over 
ten inches, and of these I am fortunate enough to count myself one.

The bullet was nicely placed in the shoulder, which was shattered. It was a little high (due to the 5500 feet elevation, perhaps), but the frothed blood at the mouth showed that the lungs were penetrated. The meat of old chamois, especially bucks, is worthless. I should have liked, however, to have taken home the skin, though the fur in early autumn is of little value. Time, however, did not allow of the lengthy process of skinning, so all I could do was to transfer the head and feet to my rucksack. Before I left the dead beast I ripped up the skin so as to enable the lämmergeier * to get to work more quickly. Enormous as this bird is, he has little strength in beak or claws; and even the smaller vultures, though better provided in these respects, will often sit a day or two by a fresh carcase till incipient putrefaction makes their task more easy.

I had been walking, or, strictly speaking, clambering, over the rocks with my load about

* Unless soon protected by the Government, this noble and harmless bird will soon be extinct in the Herzegovina. Austrian collectors pay large sums for their skins, and every pot-hunter is after them. A gendarme, even, shot one in January, 1896, at Ruiste, and they are nominally forbidden to shoot. 
half an hour, when "Whew! whew!" the alarmwhistle of a chamois, caught my ear. It proceeded from the Maligradac facing me, which was little if at all higher than my own position. Although I sat down for a quarter of an hour, I utterly failed to locate the animal, and could only suppose it to be among some shrub which crowned the hill. Less than ten minutes later I caught sight, in quite the opposite direction, of the backs of three chamois galloping behind some rocks-no doubt part of a herd. They were taking the direction of the Zeleni Pas, and I dare say I might have repeated my earliest stalk then, but I always made it a rule to satisfy myself with one a day, and rested quite content with my solitaire.

\section{NOTE TO CHAPTER XXIX.}

The following is the measurement of the big horns referred to, which were obtained in the Porim Range by my friend Lieutenant Eberhard Hollinek in 1892: length $10_{\frac{3}{4}}^{3}$ inches, greatest girth $3 \frac{3}{t}$ inches, span $7 \frac{1}{2}$ inches. Contrast my two best pairs: (1) length $10 \frac{3}{8}$ inches, girth 3 inches, span $4 \frac{1}{8}$ inches; (2) length 10 inches, girth $3 \frac{3}{8}$ inches, span $5 \frac{1}{8}$ inches. 


\section{CHAPTER XXX.}

I Au afraid the reader will have had enough chamoisstalking, so I shall not return to the subject again. The other sport of this district, however, was not interesting. Hare or roe shooting with beagles, and a few days after small game in the polje, completed the list. In this latter there were a few partridges, quail, stone-hens, and hares. I do not know that I need refer to any of those days -for the heat and drought spoilt all chance of sport-unless, indeed, to one on which I distinguished myself by killing one partridge and missing three, a hare, and a pigeon right and left. One bird to eleven cartridges was rather too much-or rather too little-so I went home; and I am glad to be able to say that I found out next day that the fault lay with a fresh lot of cartridges. Here a word of warning may be useful-never buy loaded cartridges in Austria.

During our camp at Jezero the Eastern Herzegovina was greatly excited by the news of the death of a noted ruffian, which happened thus. A portion of the Gacko garrison were engaged in 
outpost practice, and the corporal in command of a reconnoitring patrol had made his way to a rock-covered hillock in order to get a look over the country in front. On arriving there, he left his men a few paces behind and went up alone. He was somewhat surprised to catch sight of two feet and the butt end of a gun among the rocks, but would not have paid any attention to the owner thereof had not the latter suddenly jumped up and fired at him. Upon this the soldier not unnaturally ran off towards his men, calling to them to load with ball cartridge. After a second unsuccessful shot the stranger made off, but a well-directed volley soon stretched him, mortally wounded, among the rocks. He certainly died game, for his last act was to destroy some papers he had upon him - a fact which gave his presence in the Occupied Territory some political significance. On the arrival of the gendarmes-who were, of course, summoned-the dead man was identified as a noted Montenegrin robber and murderer "wanted" for a dozen crimes. The odd part of the matter is that, had the ruffian had the presence of mind to wish the corporal good morning, the latter would have taken no further notice of him. Suddenly seeing his hiding-place approached by soldiers, he no doubt rashly and erroneously concluded they were in search of him. The patrol received the reward of one thousand 
florins previously set upon his head. Only two days before, this very man had attempted a burglary in the town of Gaćko, and had only been prevented by his accidentally disturbing the house by dropping part of the "swag," from carrying it out. A few days after this, we heard of an attack on a gendarmerie post on the frontier. It turned out to have been a volley fired in the dark-I dare say by some of the dead man's friends.

The presence in the country of ruffians of this nature might be considered a drawback to camp life; but, in the first place, we were much too far away from the frontier for them to succeed in passing the various lines of gendarmerie patrols; and, secondly, this sort of thing is daily getting rarer. It is only with the greatest difficulty that the frontier posts can be evaded, and when this is done the hayduli's career, as in this case, is a short and not merry one. I dare say the Herzegovina is as safe as any part of Austria-indeed, I may say of England-though, by the way, a few days after this we had a reminder that we were by no means encamped in the New Forest or Cannock Chase. About half-past six one morning Rex began barking londly, but at so late an hour I did not feel inclined to take any notice. My wife, however, did, and, sitting up on her bed, opened the window just over it.

"It's a dog," were her first words; but directly 


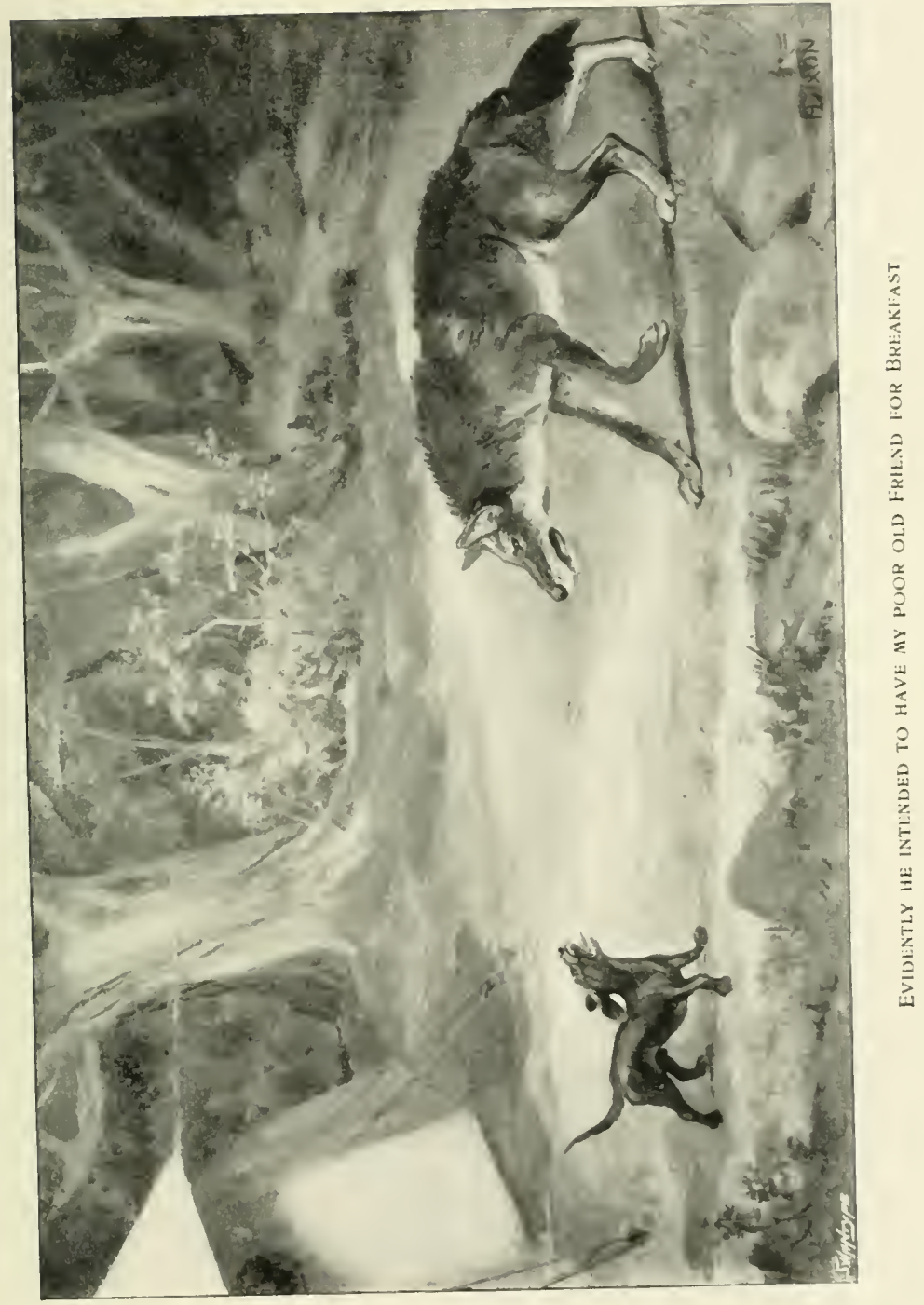



afterwards she exclaimed, "Look here, quick!" I was up in an instant, and, peering out at the side of the door, saw a wolf not a score of yards from the tent, and not four from the dog. As the dachshund barked and jumped at him he drew back, and then directly afterwards slunk nearer. Evidently his intention was to have my poor old friend for his breakfast.

Meanwhile I was wildly seizing my gun (which, of course, was in the cover and fastened to the centre rope of the tent) and cartridges; but Brer Wolf's suspicions were probably aroused by the voices, and he made off. As I started after him my wife called to me that he had gone towards the lake, and so did I. I had not long started, however, when she saw him break back to the left towards the forest. Thus, of course, my halfmile pursuit in my nightshirt was bootless. On my return I met my better half, Derringer in hand, but she also had seen nothing more. The wolf was a medium-sized one for the Herzegovina, where they grow very large. I need hardly say it was a great disappointment to me to lose him thus, for it was the first chance I ever had to shoot a wolf. That evening at sunset we heard a bear roar in the beech wood hardly a furlong away, but this was the last time we heard one. Of other noises, from the hoot of the great horned owl downwards, these woods were full all night; 
and often I have failed to conjecture what animal it was whose footsteps passed so close to our canvas home.

A third event marked that day, or rather the night following, and this was a terrific scirocco gale, which banished sleep and lasted till noon or later, considerably damaging our temporary outer fly. Fortunately, the look of the sky warned me to lose no time making all snug again before a terrific thunderstorm burst over our heads. It began with hail, and ended with three hours' heavy rain. In the middle of this we were surprised by a visitor, whom $I$ at first put down as a rather disreputable tramp, till what I took at first for an ice-axe undeceived me. It turned out to be a botanical digging-tool, and the owner a Berlin botanist, whom the storm had surprised collecting in the Velez. To make matters worse, he had lost his way in the woods, and altogether a more thoroughly saturated and bedraggled individual I do not recollect ever having seen. He must indeed have been glad to see the smoke from our kitchen. After drying him somewhat at our fire, and warming him with brandy and hot tea, I lent him an old shooting-coat, and he continued his walk to Nevesinje, where his wife was anxiously expecting him. He often came to see us subsequently, and proved an amusing companion and a capital climber. The very 
day we went north he went south-to Ragusa, I believe.

By the middle of September the weather, at this elevation, turned cold, and we had our stove brought into the tent. From that moment we never were cold again, but often too hot. In fact, we generally kept the door open. Five days later the ground was white with frost at daybreak, and we decided to move to a lower level. One last day's sport, or rather three, may perhaps be worthy of more particular mention.

Having done all the stalking I cared to do in the Velez, I decided on having one day with beaters before going on to try my luck elsewhere. At the same time I must confess that, as a rule, driving deer or antelope is not a form of sport I care for, and as far as chamois are concerned I positively object to it, for three reasons-firstly, that it disturbs and drives away the bulk of the game; secondly, that the good bucks rarely or never come to the gun; and, thirdly, the time which one has for consideration when stalking being wanting, it is almost impossible to pick out from the herd the animal which ought to be shot at. The result is that milch does form the bulk of the bag. Even an old hand at chamois-shooting may fail to distinguish the sexes, so the beginner can hardly be blamed for doing the same. Of course no sportsman would shoot at an animal 
with a lid running or standing beside it, but in the confusion of flight mother and offspring frequently get separated, and the former, if the biggest and darkest of the herd, is very likely to be rolled over. Then the odds are the youngster will die, not from want of the milk, which anyhow ceases with October, but a kid without a dam to show him where and how to seek his food, and so forth, rarely survives the rigours of a mountain winter. Sometimes a strange doe will adopt the orphan, as he may be called, for the buck, of course, never takes the slightest interest in his offspring.

None of these objections apply to what is known to Austrian sportsmen as Riegeln. In this method of driving, when properly carried out, the game is first found with the glass, and then quietly moved by two or three beaters (some of the sportsmen often acting in this capacity) towards the guns. The chamois go steadily on, and plenty of time is thus given for the selection of a victim.

There is yet another method of chamoishunting-probably unknown to most Englishmen even by description, which is called the Jagd zum Treibstock. In this two or three sportsmen only take part, and the object is to drive the game gradually to a point where even they cannot proceed. Knowing as I do the places a chamois will 
traverse, I must confess the very idea of such a thing "gives me the creeps," and besides the desperate climbing, the dangers from falling stones dislodged by the chamois, and even from the last maddened rush back of the terrified animals, are obvious.

However, on this occasion I have an excuse to offer for organizing a drive, for General Hoffmeister (promoted since our bear-hunt to be a lieutenant-field-marshal) had expressed a desire of shooting a chamois; and, although he is a wonderfully active man for an "Excellency" with sons of his own in the army, stalking amongst the Velez cliffs was a little too much to expect of him. My letter to him having suggested one day's driving (two beats), I was rather horrified when, the day after the completion of the annual manœuvres, an orderly arrived at my camp with a letter to say that his Excellency would arrive that evening, with two more officers, for three days' driving. The only thing to be done was hurriedly to make such arrangements as were possible.

Next morning by half-past eight I had my guns in line for the first beat, which was to be the only one that day. The position ran along and up the gorge to the southward of the Mushroom Ridge. For my own post I had selected that which involved the most climbing, a long 
weary way up a moraine, the upper part of which, being cornposed entirely of small stones, afforded literally no sure foothold. Still, I was up there long enough before there was any need to be. Behind me a couloir, possibly practicable for chamois, though I had never known one to use it, broke the long line of sheer precipice; and the shade of the cliffs, together with the vicinity of the snow, made waiting very cold work. However, like all other things, it came to an end, and the shouts of the beaters became audible in the distance. Nearer and nearer they came, and at last I began to think it was going to be a blank beat. Just then I heard the wished-for rattle of stones, and caught sight of the backs of part of a herd exactly in front of me. This was provoking, for I did not care about shooting any more small stuff; and his Excellency, who had never shot, or shot at, a chamois, was little likely to have a shot at these unless I could head them off. As soon, therefore, as I again caught sight of the heads of the leading ones, now coming straight up towards me, I took a snap shot at the first, and rose to my feet with a shout. At the short range I naturally overshot the "head and shoulders target" thus presented, but gained my object in that the herd turned downwards. Next below me a gendarme had been placed to act as a stop, which duty he carried out by "plastering" one 
doe with two barrels loaded with slugs. In spite of this the bulk of the herd broke past him, but one doe with her kid went downwards. It was touching to see her turn back to encourage the youngster, but the heart of the beginner at chamois-shooting is ruthless, and when the gendarme finally drove them down by pelting them with stones, his Excellency missed the doe handsomely with both barrels, she only giving him a galloping shot. The dead doe, unfortunately in milk, was, I think, the largest I ever saw, but her horns were not long.

After this beat I wished to knock off as had been arranged, but the others would not hear of it; so, in spite of my protests, the beaters were sent to drive back from the far side of the Zeleni Pas, up wind, and thereby completely spoil our chances for next day, whilst we settled down to lunch and discuss the events of the beat. In this, besides chamois, there had been a roedeer (doe) and two bears, one of which the beaters had surprised, as the elders did Susannah, taking a bath in a pool formed by the melting snow. Unfortunately, although it had been reported to me that there were bears on the Nevesinje side of the Long Ridge, I had not attached much credence to the report, and consequently we were posted much too high up for them to come to the guns. They broke out somewhere below, but apparently 
were not above taking a hint, for we beat for them next week in vain.

An hour or so later we started to walk to our new post, not a furlong distant on the Mushroom Ridge, but we made a long circuit to avoid the bad going. I stood on the saddle itself, having his Excellency below me, and the other two guns above. The beat was uneventful, and it was not till the beaters were close to us that the bang, bang, banging of a repeating rifle assured me it was not to be a blank. I must say I felt rather nervous, as I could hear the repeating action rattling away to my unprotected right. I much object to these weapons, for the reason, among others, that the user is apt to be carried away by the facility of firing into continuing after the game has crossed the zone of danger to the other guns. In this case it was not so, and after the sixth shot a voice called out, "Obacht!" ("Look out"). "A wounded bear for certain," I thought; and a minute later I descried a diminutive form coming along towards me. "Female with cubs," was my next thought; but directly afterwards I got a clearer view, and saw it was a tiny chamois. The kid passed me not three yards away, panting with fear and exertion, but never saw me. This, it was obvious, could not have been the object of such an expenditure of ammunition. A minute later a shot rang out to my left, and then the beat came to an end. 
I descended to the scene of the firing, and there learnt that the gendarme, who was armed with his service repeating carbine as well as with a double-barrelled gun, had fired all these shots at a buck "to drive it to his Excellency." How he expected to do so was not clear; but, anyway, we had no doubt that Captain F-, the $g$ _ to my left, had improved the opportunity. slas when he came down it was with a beater carrying the luckless kid. He said he had only seen it moving in the beech bushes; in which case, for all he knew, it might have been me. I am inclined to fear it was blood-thirstiness; but, anyway, the killing of kids is illegal, and in this case was well punished, for the old buck, who had been going straight towards him, was never seen again by anybody, and I have no doubt he, on hearing the shot to his front, lay low in the beech scrub till all was quiet. From the position in which he was found, I have no doubt this was the beast who scored off me so the day I mislaid my spectacles, and whom I twice had long shots at, but in vain. So ended the beat, in which some half-dozen more chamois had been seen (but out of shot) by the highest guns. About half an hour took us back to my standing camp, where three or four of the little tentes d'abri carried by the Austrian soldiery had been erected, by the side of which my thirteen-feet Piggott loolied 
a regular marquee. We turned in early-the strangers with great hopes for the morrow, in which, however, I did not share.

Next morning an hour's ride brought us to the bottom of the ascent to our posts. The arrangement of the beats was left to the gendarmes, and this time they decided to place us along the mouth of the first of the two valleys under the Botin. I did not think much of the arrangement, so I volunteered to take the left flank, and come in with the beaters. I knew my position was a very likely one for an old single buck, especially if the men were careful in beating out the Maligradac, which was just before me. Alas! they never touched it, and beat very badly, the men close under the cliffs being far in front of the others. As I came up in line with these last I heard a shot, and directly afterwards a buck galloped along under the cliffs. The range was about two hundred and fifty yards, and shooting at a rumning chamois is a waste of time; but, nevertheless, I did try the shot, allowing a little too much for his speed, as the result proved, for he wheeled sharply towards me, and finally escaped untouched. At the range, and with my weapon, it would of course have been a mere fluke; so, as I can claim no credit for it, I may be allowed to express my conviction that that buck had a very narrow shave. Hearing 
my name called, I went on, and was informed that two chamois were still before us, having taken to the cliffs, here unsurmountable even by them. Accordingly we took post in line, and a gendarme got up two hundred feet without seeing anything. Discharging his carbine had also no effect, and finally we had to leave them where they were-a result I had from the first anticipated. Whether they were really lying in some hollow of the cliff, or whether they had found a way out unperceived, I cannot say, but I have seen others ascend these cliffs where it seemed absolutely impossible they could do so. The second-a woodland-beat was blank; and I expected no better result, the weather being much too fine and hot for the game to lie so low down, though of course there might have been roe.

That night our camp was in the Velika Poglizza, a forest-surrounded plain some miles to the westward. As, of course, I had not moved my camp for one night, I also occupied one of the little tents, and found it very uncomfortable, as I could not stretch out my limbs in it. Moreover, it was such a very cold morning that about half-past four I could stand it no longer, but made my way to the camp fire to have my last hour's sleep.

That day there was to be only one beat, as his Excellency had the six hours' ride to Mostar 
before him. It was to be a double beat, from right and left simultaneously. The position was a beautiful one. Before the right-hand guns was the high isolated peak of Ruvinikigradać, a favourite resort of the chamois, while the left one closed in a long corrie between that peak and the main line of cliff. Alas! again the beaters spoiled our chance, which seemed so promising when we heard one of them let off his long Turkish gun early in the beat. They finally appeared, all in a knot in front of the left-hand guns, and reported that they had seen a herd of nine, which had gone up the gradac. In other words, had they beaten properly these must have come to the guns. The mistake was ours; we should have changed our beaters that day, and taken Smrcanj men. The natives of this country beat fairly well, but on their own ground. Take them to a hill with which they are unfamiliar, and they are no good at all. The Lakat men only know the Velez as far as the Botin; beyond that the woodcutters and shepherds below to the Mostar Sub-prefecture. After this it was small consolation to hear that the other beaters had had no less than thirty head before them, but had failed to hold them, and they had all gone "out over," as they say on Exmoor.

So ended our three days' driving. We returned 
to camp to lunch, and thence took our separate ways-his Excellency to Mostar, the other officers to their garrison, and myself to our camp to make final arrangements for marching.

The moral of this shoot lies on the surface, for its results prove that, of all forms of sport, driving requires the most local knowledge, and that for those who have not that knowledge to interfere in the arrangements must needs be fatal to success. Secondly, it illustrates thoroughly all the drawbacks to chamois-driving I have previously referred to-does and lids shot, the bulk of the game driven off the ground, and hardly a single good buck brought to the gun. 


\section{CHAPTER XXXI.}

We looked forward with great interest to our move to the Upper Narenta valley, feeling ourselves almost explorers in going there. It is true I had been preceded thither by two Englishmenour consul for this district and a general officer, both keen fishermen; but I believe I am right in claiming for my wife that she, at all events, was the first Englishwoman to see the beauties of this romantic neighbourhood.

Of course the first thing to be done was to strike camp, which we did one morning, and transported everything to the Lakat barrack by oxwaggon, in readiness to leave next day. We had a good deal of trouble with our pack-animals, or rather with their owners, that morning; and after I had sent one horse back to Nevesinje with boxes we could spare, they protested they could not possibly manage with the remaining two. (The fourth was for my wife, I preferring to walk the score of miles we had to go to enduring the miseries of a native saddle for six or seven hours.) My reply was that they had promised to transport 
us to Glavatičevo for half a sovereign, and to that I should hold them, whether they used three horses or thirty. (I may here remark that the proper charge was about half that sum, but in the end, as will be seen, I had to pay one-fourth more even than this.) However, the artful Turk was too many for me in the end, for, on making a start, we found the two pack-horses gone on, and my wife's horse loaded with such an infinity of minor paraphernalia as to make the idea of anyone's riding thereon quite ridiculous. Protestations were quite useless at this stage; but we were told we should be able to get another horse at Klunj, the first village en route. There was nothing for it but to start on foot, and in this way we covered. the first hour and a half of our journey, which led along a track through hazel covert and over rough, sharp rocks.

Arrived at Klunj, we fonnd, of course, no horses, they having gone to graze; and it was not till I threatened to add my wife's weight to one of the loads that our Turks really bestirred themselves, and finally turned up with a diminutive flea-bitten grey, with a much worse saddle than the one for which they had coolly substituted a pack-saddle before leaving Lakat. Worse than all, it only had one rope-girth-a fact that was destined to give trouble later on. The packsaddle of the country is peculiar, being very high, 
and coming right out on the neck of the horse. So high is it that a horse with an empty saddle covered with the inevitable white blanket looks already loaded. It is secured with a rope-girth and crupper, and, in addition, a loop passes under each forearm, the galling effect of which is evident from the scars on every horse here. All the horses here are shod with the Turkish bar-shoe, which covers the whole foot. Many of the Turks have considerable wealth in horseflesh, and it is quite common here to meet, as we did soon after leaving Klunj-where we had lost over an houra train of twenty to thirty beasts with good packsaddles (not a bridle amongst them) and rugs, their jangling bells reminding one of past days in Andalusia. But here is no arriero; the rear is brought up by one or two Turks on picked horses, which, under the double influence of the murderous bit and of the sharp corners of the shovel stirrups, carry themselves smartly enough. Every horse so ridden long naturally becomes a stargazer. Although deprived of his arms, the Turk (so the Mohammedan Slav is always called here) still looks unmistakably the lord of the country. His carriage and bearing are confident and haughty; but I found them very good fellows, and more pleasant to deal with than the Christians, though I have known the two to combine to get to windward of the stranger. 
Before long our road became a paved bridletrack, which at first suggested the idea that it might be a Roman one, but that it wound about much more than the work of the legionaries is wont to do. After about a mile, however, it ended as abruptly as it had begun. Presently we came to a gravel-pit which had just fallen in and badly crushed two Turkish lads. Unfortunately, we could render no help except to send people from the village of Borovecici, just beyond, who went to fetch them in with a cart. The usual trouble with pack-animals-a slipped pack-delayed us here nearly half an hour, and then we went up to the pass between the Crnagora and Ledjenice hills, on the latter of which our Turks said there were plenty of chamois.

On the other side of the pass lies a well-cultivated plain, or rather tableland-the Krusevicko Polje, with the village and gendarmerie barrack of Krusevljani, from which it takes its name, some mile or two to our right. We halted for lunch at the forest-keeper's house at Luke, another village a mile or two on. The leeper himself was absent; indeed, I had seen him at Lakat in the morning. These men are-very wrongly, I venture to think-allowed to shoot, and consequently all their time is spent in this way instead of looking after their districts.*

* I have left this passage as originally written, so I think it only right to say that a high official of the Government has 
So far our journey had been anything but interesting, but we now began to get glimpses of the deep well-wooded gorge into which we had to descend. The next village, Zaborani, was the last on the tableland, and soon the track began to descend sharply down the limestone rock. The road was anything but a pleasant one seen from the saddle, and I was not surprised when my wife dismounted. The descent, however, continued for longer than she cared to walk, but when she wanted to mount again the saddle turned twice in succession, and she was obliged to ride the next few miles cross-saddle. Meanwhile the scenery had been getting finer and finer. The track ran along one side of a terrific ravine, whose crowded sides were everywhere broken by peaks and masses of rock. Further on, the main gorge of the river, backed by the Visočica Range, appeared. We had to climb out of this ravine again, and then we caught sight of our goal. Two large buildings showed up on either side of the winding stream, of which the nearer was the gendarmerie barrack, and the other, we were told, the bishop's house. At last we heard the rushing of the most ideal trout-stream I ever saw. This part of the Narenta strongly suggests the Wye valley, allowance being made for the hills here being far higher. Soon since assured me that this privilege will shortly be withdrawn from the keepers. 
after five we reached the river, and ere long were unloading in front of the pretty little defensive barrack of Glavatičevo.

This place played an important part in the insurrection of 1882 , for it was here that the insurgents made one of their most determined stands, and in forcing the bridge (the present structure is of more recent date) the Austrian troops lost fourteen men.

The village of Glavatičevo lies at an elevation of 1130 feet, and, as the pass at Borovčici must be over 3000 feet, some idea may be obtained of the angle at which the track descends. We had now reached the prettiest place I had yet seen in the Herzegovina. The gendarmerie barrack stands in a horseshoe curve of the stream-a position which it shares with the mosque, the apex of whose minaret is deftly covered with tin from old kerosene cases. From the opposite side of the stream, but a little lower down, the so-called "bishop's house," which turned out to be a small Franciscan convent, overlooks it. Below this the vale opens ont, and is closely cultivated, the maize-fields and walnut trees being a proof we had reached a very different climate. The river makes an endless succession of S's, the one bank being always a tree-covered bluff, and the other a cultivated slope fringed with osiers. The cliff opposite the barrack is almost bare limestone, but has a few pines growing on it; 
the other hills have dense vegetation right up to their rocky peaks. The banks are diversified by endless streams, which dash down from the hillsides to join the Narenta, each forming a romantic glen. On the sunny side of one of these I came across a couple of small vineyards, but they did not look very promising. The elevation, say 1300 to 3000 feet, is no doubt too great. Narrow as the valley is, it does not prevent one's obtaining glimpses here and there of the higher hills which stand back from it, such as the Osobac (over 6600 feet) and the Ledjenice, which we had passed on our march.

The day after our arrival, after a longish search up the river, we finally selected as a site for our camp the toe of the horseshoe before referred to. Although we were not a hundred yards from the mosque, a screen of scrub and bushes ensured complete privacy, whilst on the other side we had the river within five yards, but, as I imagined, sufficiently below us in case of a "fresh," as we say on the Wye. The vegetation down here was of course very different from that of the Velez, and, sitting in the tent watching the river flowing past behind the alders, one was irresistibly reminded of house-boating on the Thames. But here were no crowds of boats to enliven the scene; only flocks of sheep and goats, or pack-horses filing along the tracks cut on the opposite limestone cliff. Or it 
would be a burly priest, his black robes very inappropriately crowned with a greasy fez. This headdress - the Turkish fez without the tassel, but with the bit of red stuff to which it should be attached-is the almost universal wear of the regular clergy in the Herzegovina, at all events in the country districts. Near Mostar I have seen a "bowler" hat used, but they have the special privilege of not going bareheaded. These Slar friars are also allowed not to shave the upper lipindeed, some of them wear most carefully kept moustaches nearly a foot long; nor do they shave the crown of the head.

That first day the river was a lovely sight, the pool opposite being of a more intense blue than I have ever before seen river-water, whilst what we drew for use was as clear as crystal. (The drinking-water came from a spring a hundred yards off.) Alas! the next morning it was like café-cu-lait, for the weather was not kind to us those first days, but rang the changes on thunderstorms, heavy rain, and dripping fog. The last seemed quite homelike, but was a decided novelty in the Herzegovina. No weather this for the quest of chamois on the higher ground, so I contented myself with a milder form of sport with the beagles along the river-banks. By the way, a few furlongs below our camp, the river commences to be the boundary of one of the five great sanctuaries for game which 
the Government has established. These, I may add, are to be let, and are well worthy the attention of English sportsmen. Some idea of the extent of them can be formed from the fact that this one, with the adjoining one, forms an unbroken area extending thirty miles in length by more than half that width. In these no gun has been fired for years except illegally, and probably very little so.

Often and often during those first days did I wish I was a fisherman. The first day the water was, of course, too bright and clear; but after that night's rain, or better still the next day when it had cleared a little, even a duffer ought to have been able to grass some of the big Narenta trout with a worm. Unfortunately, not having wetted a line since boyhood, I had no tackle of any sort, nor any means of getting at them short of the only one I believe prohibited here-powder and shot. I must own to having looked covetously at the first fish I saw lying in one of the tributary brooks, and had he been bigger I think I should have given him a barrel-a proceeding rarely attended with any success, except, indeed, with big pike among the reeds on a hot summer day. Certes, I did once, in France, pot a carp-and a viper in the same pond-with a rook rifle, to the unbounded wonder of the natives; but that, as Mr. Kipling says, is another story. The sad fact remained that 
to us Narenta trout were only obtainable with a silver hook. N.B.-Price of trout here $8 d$. per olice (about $2 \frac{1}{2}$ lbs.).

A very few days after our arrival the higher hills were covered with snow, which led me to think we had moved in time. Down here it was warm enough; in fact, at times oppressive, and one night we had to sleep with the tent door open. Of course it would have been easy to have the stove outside, but the weather was very unsettled, and in camp it is worth anything to get the tent dry and snug quickly after rain. The difference between this and the cold, clammy, everything-damp feeling when there is no stove must be experienced to be appreciated. Glavatičevo was in many ways a far superior camp to Jezero, or any of our Dalmatian camps. We never had the slightest difficulty in getting stores; indeed, it was quite wonderful what the village shop could produce. Besides the necessaries of life, it was really stocked with luxuries; for instance, we replaced broken tumblers, decanters, and even lamp-glasses there. They even had paper, not certainly of the finest quality; and I dare say some of the editors who are good enough to print me wondered what I was using for manuscript.

I think, though, that what conduced most to our comfort was the excellent camp-servant that we got here. He was a Turk, by name Duran. 
Poor fellow! he was deformed, but made up for this drawback by activity and energy. Not only did he do all we wanted, and, after a very little teaching, do it well, but he made a capital huntsman, and actually managed to go with me shooting two or three times a week to work the hounds, and yet got his regular work of cutting wood and fetching water, going for supplies, washing up, and cleaning cooking-gear, done. Duran was a most popular man, and everybody had a smile for him. On shooting expeditions he was autocratic, and I have often been amused watching him giving his orders to great fellows twice his size. But then, he carried the coffee and the tobacco, and dispensed these luxuries as he thought fit. When we were alone, I used to let him have my second gun (the little weapon with the left barrel rifled I had used in Dalmatia) to carry; and Duran the lovac (hunter) was the butt of many village jokes, especially those of an old hodja (pilgrim, i.e. one who has been to Mecca) who lived a little way up the Razica, and, I believe, conducted the prayers in the mosque. Anyhow, he was always a great swell on Fridays, in a long green coat, which may have been silk. Duran, however, silenced the critics by breaking a roebuck's leg one day. I am sorry to say we did not get it; and I afterwards found out that he had surreptitiously removed the bullet from the 
cartridge and substituted native slugs for it, which considerably discounted the merits of the shot, but the critics probably did not know this.

I need hardly say the rude waggons of the Velez villages had disappeared. Glavatičevo, though sufficiently civilized to boast a telegraph wire, which, however, does not involve telegraphic communication therewith, is only supplied with those things it cannot produce by pack-animals, and this is likely to be the case for many a year to come. The natives, mostly Mohammedans, as in the Velez, are less rough than the latter. They gave us no trouble in the camp; and not even my shooting-kilt, which had been an object of constant curiosity in the mountains, was too strange to overcome their sense of decorum.

A curious feature of this district are the hay and corn stacks, which are always arranged on a tree, round whose central trunk the branches are cut so as to support the pile.

The plentiful fruit of the district was unfortunately over when we arrived, except, indeed, the walnuts, which were selling at three-farthings a pound. There was, however, an extraordinary show of wild berries, such as hips, haws, privet, and so forth. One bush, which was loaded with fruit, was new to me. Its fruit was plum-shaped, a little larger than a bean, with a large stone, and, though not very good eating in its natural state, 
it made very fair jam. Unfortunately, it was impossible to eliminate the stones, however much one boiled it. It was, perhaps, best as a substitute for red current jelly, with hare or venison. Perhaps this fruit is the Myrobella, or cherry plum, which has been much advertised in England of recent years as a fencing and covert plant.

Partridges, whether Greek or common, seem non-existent here; but hares are plentiful, for the good reason that only one man in the district has a licence. I refer to the riparian district, for up in the Visočica I saw plenty of stonehens, which come down in winter almost to the Narenta. What did surprise me was to see two seagulls flying over the river one day. But my best piece of good luck was to shoot (on three separate days) three hazel grouse. These, though common in Bosnia, are rare in the Herzegovina, and I never met another sportsman who had bagged any. The last time I had seen this bird was in the Ardennes, but it is of general distribution throughout continental Europe. I have often wondered it is not introduced into England. It is, however, a difficult bird to bring to the gun. 


\section{CHAPTER XXXII.}

Soure days after my arrival, a Turk, by name Meho Didic, was produced, who was said to be knowledgeable in the ways of the game. From subsequent experience, however, I fear he was an old fraud. He said he could take me to good ground for the beagles, both for chamois and roe-deer. Now, at that time I had no opinion at all of chamoisshooting over dogs, though I am now prepared to admit that it is a form of sport which, like so many others, grows upon one. Anyhow, I put myself in his hands, and on the appointed morning started off. Although I have spoken of the little hounds as "beagles," they are really part of $\mathrm{Mr}$. Allgood's unentered draft-harriers with a foxhound cross, standing about sixteen inches, and just the thing for this country. Our way lay back along the road we had come from Lakat till we reached the spring I mentioned, when we struck a forest path, which ended in forest without any path, till finally we emerged on a ridge covered with scanty pines. Here my Turk placed me, and went on to draw back to me. Soon, however, I 
made out with the glass one lot of cattle and another of sheep on the rocky slopes opposite to me-no chance of chamois here. Sure enough, the old man returned to inform me that the game was higher up. "But," said he, "it's a splendid place when there is snow; " but as the chamois season ends here with October, * this was no help to me. We then climbed a ridge behind us, and my guide pointed out a big, strong covert as a good place for roe. "Then we'll draw it," said I. "But you'll not be able to see anything." "Quite so; that is why I am going to stay up here, whilst you go in with the hounds." Whether he drew it conscientiously, I can't say; but as I got near the lower end of my ridge the hounds went away with a hare at the bottom, and ran her over the opposite hill-a pretty clear proof that they had drawn close, as any hounds will find a roe much more easily than a hare.

I joined my Turk at the bottom, and sat down to eat my lunch. Just as I was finishing my pipe the hounds returned, and were coupled. "Where shall we go now?" I asked. "Home," was the answer; and, on ascertaining that the choice lay between a draw three hours' walk on and hare-hunting, I agreed-the more readily as

* Perhaps this is in the interests of the game; but in those of the sportsman, September 18 to Norember 30 would be far preferable to August 18 to October 31, as at present. 
I had been out a good deal lately, and did not want to trash the hounds. On this first day, then, the only living thing I saw was a common salamander (a proof how much damper these woods are); but the autumn tints of the woodlands, notably the scarlet of the sumach, which grows everywhere, were wonderfully fine.

Three or four days afterwards I had another try, and on this occasion I handed over my second rifle to old Didic, and took Duran to work the hounds. Our way lay along the river to the hamlet of Biskup. Near this is a romantically situated Bogumilite burying-ground, buried in exceptionally fine old trees. As usual, some of the monoliths are enormous, but only one still bears traces of conventional design. A little beyond this a curious rock stands out from the woodland. At first sight it looks like a colossal statue of Mephistopheles-horns, cloak, and club-foot being all distinct; but this is because one then sees it end on. The side that faces the river is three or four times as long as the end, and stands firmly enough on its natural pedestal. Below it lie some ruins of cireular masonry, which I at first put down as defensive, but, on seeing some ancient Turkish tombstones near, finally decided to be the grave of some personage. Here we crossed a large brook by a single log bridge, and turned up along its further bank. 
An hour or so further on a hare crossed the path - a bad omen, destined to be justified. We now left the hounds, and ascended a long steep ridge. After a good bit of this, old Didic sat down to adjust a sandal, and then said, "Now we'll go up the hill." This remark seemed to me superfluous, as we had been rising ever since we left camp, but when I found myself turning the shoulder of as awkward and sheer an aiguille of rock as I had seen in a season's chamois-shooting, I knew what he meant. Afterwards, however, the going was better, and finally thicker wood promised easier slopes. From this wood we emerged on an edge so tremendous that anything at the bottom would have been quite out of shot. Didic, however, said it was a good pass for chamois, so we took post. The opposite hillside was a mass of similar cliffs and rocks, but, unfortunately, again the gorge was far too wide to shoot across.

We had not been half an hour waiting before I heard the sound of the grelots, or bells, attached to the hounds' collars. 'This is a French dodge, and an excellent one for shooting over hounds. In the first place, the game is disturbed by the sound and gets up, making it much easier for the hounds to find; and, secondly, it is an inestimable advantage to know at once whether an animal heard approaching one through the 
covert is a hound or not. Duran had misunderstood his instructions, and the beat had failed. Old Didic cast up the gorge for half an hour, but with no better result.

After this we had about an hour's climb along the side of the main hill, and villainous going it was. Finally, we emerged at the beginning of an extraordinary ridge which runs out for much over a mile from the parent hill, though nowhere three yards wide. Here Didic made a mistake, as it turned out, for he kept the hounds too long with us. At last he sent Duran down to the brook below on the one side. The ridge we were on is excellently adapted for shooting, having only occasional pine trees on it, of which almost every one was mutilated by fire and axe. This wood is the principal article of export from Glavatičevo, and no wonder, as it sells in Mostar for about a penny a pound for fire-lighting purposes. One tree we passed had recently been struck by lightuing, which had scored the trunk from top to butt in a perfectly regular spiral. I believe it is rare for resinous trees to be struck. We sat down at what the old man said was a good pass. It certainly looked like one, but Didic did not seem to think precautions necessary, as he cracked walnuts and smoked a cigarette.

After a bit we moved on, but had not gone 
far when I heard Harmony running behind us, and presently the others joined her. After they had been running for about twenty minutes the cry unaccountably ceased, just as it was getting near us. I heard hounds once again further down the stream, but only for a minnte. Of course Didic said it was chamois; but I believe it was only a fox, and that he got to ground. The fact is, there was not enough snow above to drive the chamois down here, and I doubt if there often is till the season is over. This year there certainly was not, for I revisited the ground three or four times, but only to find it covered with flocks and herds on each occasion.

Presently the ridge divided, and we followed the southern part down through a wood (which the old man said was very good for roe) to the stream, where we found Duran, and where the hounds joined us. After I had had some lunch, we had a steep climb up to the road by which I had originally come to Glavatičevo. One final, and blank, drive for roe ended the day. This was a disappointment-ten hours out, and a lot of climbing for nothing. Both the men had nothing to say except, "Plenty of game in the Visočića;" so I decided to make this the ground of my next expedition, even though it involved sleeping in a native hut.

It was, unfortunately, too late for me to think 
of learning the ground for stalking purposes, so I decided to try in the local fashion with hounds, and accordingly started with Didic (who proved quite useless) and Duran one October afternoon. Besides these two, we were to pick up en route a mighty hunter called Joso, the Knez or headman of his village. An hour's walk brought us to the said village of Razice, our way thither leading up the right bank of the stream which enters the Narenta opposite my camp. Having with us two of the natives of the village, we were received at a Christian peasant's house, and regaled with a local delicacy-rotten pears. I fancy these are prepared by keeping them in water, but anyway they are quite brown, much in the condition in which we eat our medlars.

Whilst we were waiting here, a peasant, armed with a long flint-lock, arrived at the house with a pack-horse, carrying the entire equipment for distilling slivovitz (brandy made from plums). The machine was of a primitive nature, furnace, boiler, and a big tub for the worm (a straight tube) to pass through. The horse, a niceish-looking grey colt, was dead lame, having cast a shoe, perhaps a dozen miles back. I told the travelling distiller his horse could do no work for a score of days, whereat he pulled a wry face. After a short time Joso, accompanied by his famous hound, Vića, turned up. She was a fair-lookingr, harrier- 
sized bitch, with white face, paws, and stern, and stood perhaps eighteen inches. Poor Vića! this was her last hunt; a week or so afterwards she went into the woods without leave with a cord on her neck, and committed involuntary suicide by hanging herself.

As we left the village we passed a score of Turkish women and children holiday-making in a plum orchard. On our approach the forms hastily became shapeless linen bundles; in one case one wrapper enclosed three of them. Village Mohammedans are not usuallyso particular, and in this case my presence was probably the reason. Our way wound up and up along the sides of the ravine by a fairly good track. Towards dark we reached a collection of summer huts, without having noticed any other sign of game than the stone-hens calling among the rocks. At first there was some difficulty, because most of them were still occupied by shepherding peasants; but at last we found an empty one, and soon had a fire blazing up, with a leg of lamb roasting on the spit in front of it. As usual, one or two natives dropped in, and in answer to my question said they would not go down till the first snow, perhaps in ten days, perhaps in twenty. As a matter of fact, I found them there four weeks later, though there had been some snow.

Our quarters were very lively. A heap of straw 
was arranged for me on planks by the fire, and I rolled myself in my rug thereon, but not to sleep. The sportsman who cannot stand a few fleas had better avoid the Herzegovina, even its best hotels. But this time it was a flatter insect that I could see by the light of the fire swarming about the old logs, to my disgust. Besides the "Norfolk Howards," the chatter of the natives banished sleep; but the strangers dropped off, leaving my people to snore, long before I closed my eyes. These senner huts, as they would be called in the Tyrol, are open to the sky at one end under the roof, making it necessary for some one to wake up pretty frequently to replenish the fire. One advantage of such quarters is that early rising is no difficulty, and we were off at daylight.

Our party was increased by one, my men having protested that they could not carry my blanket. The fact was, old Didic was perfectly useless, and I never took him again. So I chartered an Albino Turk, by name Bosco, to act as porter. Our way led through a fine pass, thickly grown with stone pines. At every wind of the track we got a finer view of the panorama of Herzegovinian hills behind us-Živan, Cervan, Crnagora, and once the peaks of Velez. At last we reached the top of the pass. Here are several burying-grounds, that of the Bogumilites once again raising one's wonder how on earth those old 
heretics could have transported these great blocks up here. No doubt all of those who lie here fell in battle, for the strategic importance of the spot is obvious. Indeed, it seemed to me that several of the Bogumilite monoliths had been overthrown to form a rude breastwork for some of the Turks, whose turban-headed gravestones also dot the hillside.

Here we left this path, and wound up and up the hill to our left, a magnificent eagle soaring above us. After an hour or more of this, we came suddenly out on the edge of a tremendous gorge, in the bottom of which the Grušća brook flows. From a detached peak of rock Joso and I had a preliminary spy, but in vain, among the pines on the opposite side; so we went on. Half a mile further on we came out on another point of vantage; and after a long search the sound of a rolling stone guided our eyes to a small herd. Joso, however, decided this was not good enough, and that he would take me to a better place "a little further on."

Now, this was the beginning of all my troubles, for we wound on and on over the broken tableland of the Visočića for hours, till at last we reached the summer huts of Čolavići, now deserted, and deposited our impedimenta in one of them. Joso even left his baggy breeches and his turban, continuing his walk in skull-cap and 
drawers, which looked like business. Leaving the bare limestone peak of the Ljeljen (nearly 6400 feot) to our right, we climbed a last hill, and came out on the south side of the Rakitnica gorge. This brook is the most important feeder of the Upper Narenta, and its ravine is stupendous, reminding one of the descriptions of the canyons of America. Here we espied the slope under us, which is practicable to the edge of the cliff itself, but in vain. A little further on we prepared for action, and it was high time, for the day was well advanced. Bosco and Duran were to go down with the hounds, and stop the game running back, while Joso, I, and old Didic with my second rifle took post a quarter of a mile further on. Here I had a stand overlooking two couloirs, which seemed likely enough.

For some time we watched the two descending beaters, and at last heard the shouts with which they uncoupled the pack. Not two minutes later the native bitch-who, by the way, was much too free with her tongue-opened. Her note was monotonous and peculiar- "tow-tow-tow" unceasingly. However, this time she was right, for my hounds scored to cry, and it was soon obvious there was game enough on foot. Presently I made out a chamois with the glass. For over a minute it stood on a ledge, looking and listening, and then turned down. Then two more crossed an open 
glade towards me, followed a minute or two later by another couple. I hoped to see all these again, and should have done so, no doubt, but our two Turks, instead of going well down, kept along the top, and enabled the herd to break back. Vića went off on one line, and two of my hounds on another.

A few minutes later I heard Dinah's vengeful voice below me, and presently a flock of Alpine crows (a sort of yellow-billed chough) began wheeling about and cawing down the couloir to my left. Mindful of rooks and a hunted fox at home, I peered down the cliff and saw a single chamois coming up best pace. I promptly got myself into position to command the nearest and best place on the couloir; and, as luck would have it, he paused there to look back, when a bullet through the heart sent him rolling down almost to where Dinah, mute from the excitement of the view and the steepness of the hill, and also surrounded by a mob of crows, was following on his line. This ended the beat, and the rest was blank. The view from my post across the gorge to the quaintly placed village of Lukomir, on the very edge of the opposite cliffs, was very fine. We were now within a very short walk of the Bosnian frontier. Over my head I counted no less than twelve vultures sailing in circles, and yet the buck had 


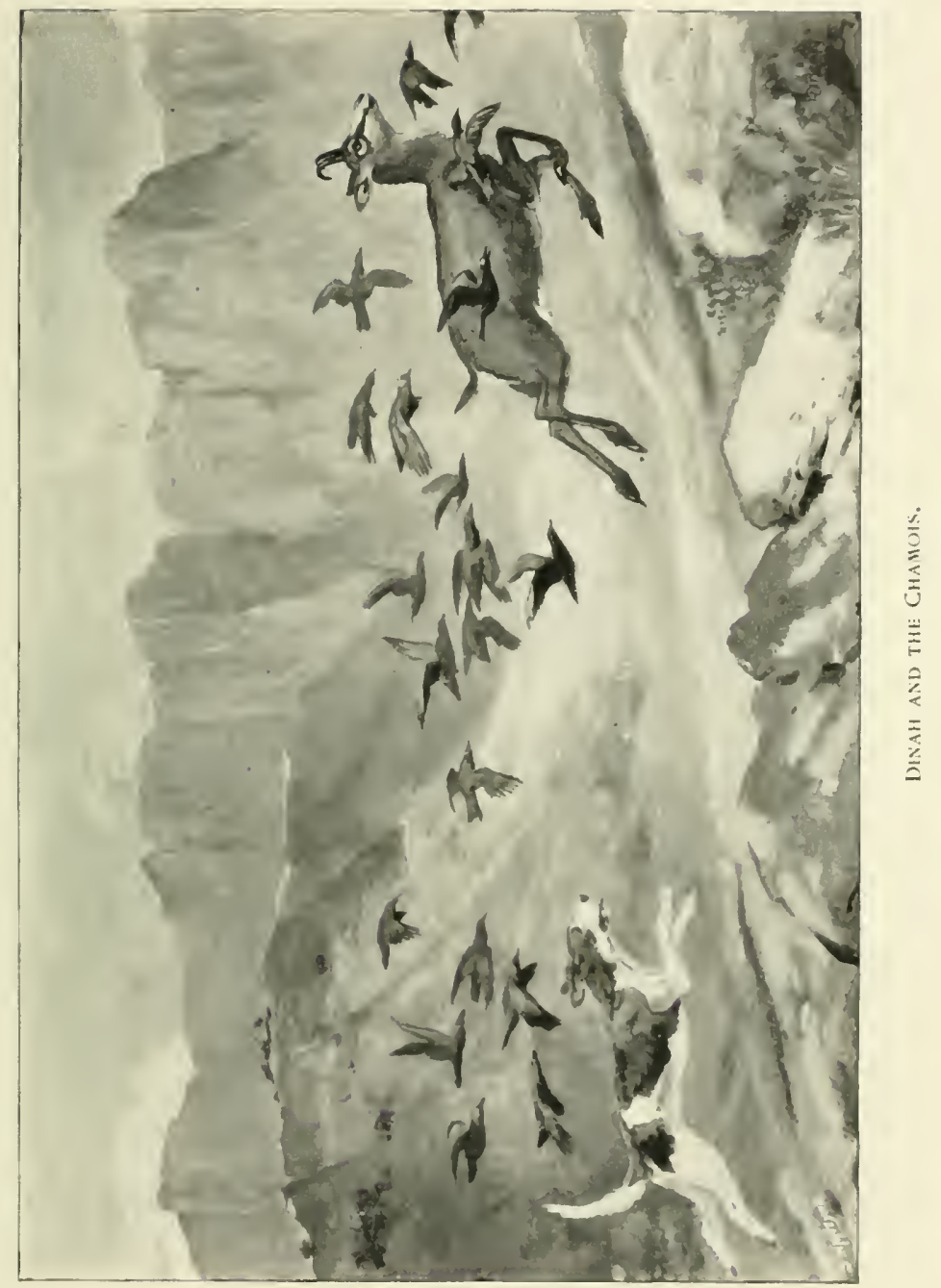



not been gralloched half an hour. It was now too late to do more, so we returned to the hut. En route we took up no less than two iron 60-1b. traps, proving that somebody else thought there were chamois about. We got to the hut soon after four, and Joso decided to make a further march, so as not to have so far to go the next day. Truth to tell I was a bit beat, but was not going to let my companions think so; so I agreed.

About an hour and a half brought us to some summer quarters of the Grušća villagers. One was a good hut, but the fleas were so awful that we speedily left it for a tumble-down affair, evidently used also as a stable, which the men soon cleared out. Tired as I was-for we had practically been going all day-I could not sleep for a long time for what Mark Twain called the "genuine Swiss chamois." I am of the same mind as the Frenchman who said, "Ce n'est pas la piqure dont je me plains, mais la promenade," and certainly there was a grand promenade on me that night. I had incautiously sat down near the first hut, and got my kilt full, and, as I was using that garment as a pillow, they kept on jumping up, literally two or three at a time, on to my neck and face. However, exhausted nature asserted herself at last, and I dropped off to sleep. Towards morning it was 
very cold, for the hut only had half a roof, and the wind whistled in everywhere.

At daylight we were off, and as we started it began to rain. After a short walk we came out on the Grušća ravine, above the spot where we had seen the herd the day before. The sun was rising in angry redness. No time was lost; we took post, and the hounds were uncoupled. They found at once, but unfortunately ran back. The sound of their music disturbed another herd of nine beyond our posts, and these went out at the top. This was a bad beginning. Nevertheless, as soon as we had recovered the hounds we went on and took post again. Again the hounds were put into covert, when down came the most awful blinding, deafening rain. In its lulls I could hear hounds running; in fact, the place was alive with chamois and roe. But against such weather no one could strive. As soon as I could collect the little pack I gave the word for home, and walked on for four hours, cold, hungry, wet, fagged out, and wretched, through the rain, which changed to snow later on.

At last at three o'clock I reached the tent, to find a cheery fire and a hot bath waiting, and food, the first thing I had eaten that day, except a hard-boiled egg at daylight.

This was by no means my last visit to the Grusca ravine, nor my last outing with Joso and 
IN THE LAND OF THE BORA.

the travelling distiller, who turned out to be his brother Mathis; but there was so much similarity about these hunts, except indeed in the weather, that the description of one may well stand for all. 


\section{CHAPTER XXXIII.}

I HAVE never been very lucky at anything, but I must say my luck at Glavatičevo was, as far as sport is concerned, more "dead out" than usual. First of all came the failures just related; then several unsuccessful attempts at an old roebuck which frequented the hill exactly behind my camp. Ignorance of the ground spoilt my first chance at him, for I posted myself at the southern end of the wood, where, as I afterwards found out, it was practically certain no deer would ever break. The hounds ran him in the opposite direction for some hours, being seen by a Turk at the Borke Brook, having thus made a five or six mile point, right into the Sanctuary. In a few days the buck was back again, but I posted myself above where he broke, and, to make a long story short, I never even saw him, though Duran did repeatedly. Nor was my luck any better with another buck which used a wood behind the village of Dudle, at the lower end of the Grusca valley, and which always beat me by keeping to the 
woodlands, on one occasion passing my "huntsman" within a couple of yards. Of course, he was unarmed on that occasion. Several expeditions to the Biskup valleys and other places were quite fruitless, simply because the ground was never quiet. The last time I went there the place, even at this late season, was a regular Noah's Ark, the whole hill being covered by Christian peasants from the Krusevljan district, with their filthy pigs, in addition to sheep, cattle, goats, and dogs innumerable.

If I inflict the account of one more failure on the reader, it is because the expedition in question had some points of interest apart from sport.

I was very anxious to complete the Herzegovinian quintet of larger game, bear, boar, roe, chamois, and wolf, before going into winter quarters. A chance at the last-named animal is always more or less of a fluke, as the foregoing pages amply prove; but, careful precautions being taken, the killing of a boar can be reduced to a certainty, and my next attempt was to secure one.

The boar is the rarest of the large game of this province, although common enough in Bosnia. It is only found in this district, and here, unfortunately, a large number had been killed by the peasantry in the deep snow a couple of years 
before my visit. Still, the Wachtmeister commanding the gendarmerie post told me that all the summer a "sounder" of pig had been using the hill of Chepa, a fairly high ridge in the angle below the confluence of the Rakitnica and Narenta; so on the 20th of October I started off in search thereof. I had strong hopes of being able to do some good, because for the first time the tent was that morning covered with suow. In the sequel my hopes of gaining assistance from tracks were disappointed. The night had been bitter, but we felt it little, except that once or twice I woke up to pile faggots up in our invaluable stove.

At Kasiči, the second village down the river, we stopped to obtain local information. I had been advised to make use of an old Turk, by name Fezo Zaklan, erstwhile a mighty hunter, so we made our way to his house. In answer to Duran's shouts, he asked us to come in. This was my first introduction to a Mohammedan village interior. The old man was huddled together by the fire on a settle, on to the foot of which the water from the melting snow was dripping. (Lest this should be taken as a sign of extreme poverty, I must add that on a later visit I found the roof under repair.) Opposite him was another settle forming a chest, and this, with a couple of low stools and some household implements, formed 
the furniture of the place. There were two windows, one some nine inches square with a shutter, and a smaller one with a pane of glass. The old man (he told me afterwards he was eighty-four) was alone save for one granddaughter -a pretty child, as, indeed, most of the Turkish children are. On our explaining the object of our visit, the old fellow commenced his toilet, which consisted in putting on first his opanke and gaiters, and then a pair of blue breeches, so ragged that I could not conceive how he knew through which of the many holes he must put his foot. On a later visit two such pairs were produced for him to choose from, and we had a hearty laugh with him over them. But when he came to pay me a visit he was much smarter, and his son was generally well dressed. A long green cummerbund topped these, over which came the inevitable belt with its cumbrous sort of sporran attached. The jacket was even more ragged than the trousers, and this time he really was puzzled as to the hole to put his arm in.

After we had climbed down a dangerous ladder to terra firma, I was surprised to see my decrepit patriarch appear as a fairly active grey-bearded mountaineer, who shouldered my second rifle and led the way at a very creditable pace.

The village of Kasiči lies on the shoulder of a pointed peak between the two streams, which here 
flow through tremendous clefts of rock, singularly wild and beantiful. On the far side of the Narenta men were at work making a road, and reports of blasting reached our ears at intervals during the day. Opposite us another cleft showed where the stream from Borke Lake falls into the river. On a ridge above this beautiful little piece of water stands a villa, the property of the (then) Prefect of the Province, who has since been promoted to be Administrative Director of the Central Government at Sarajevo. I need hardly say that this is the only house owned by any Western European in the Eastern Herzegovina.

A steep and bad track led us down to the Rakitnica, which we crossed by a dangerous-looking bridge some fifty feet wide, and as high above the stream. It was formed of planks laid across two single tree-trunks, and had no handrails of any sort. A furlong further on, flap! flap! up got a woodcock at my feet-the first of the year, and very early for this country.

Presently we separated, Duran with the hounds going along the valley, whilst I followed Fezo up a steep, bare limestone ridge into the dripping covert above. Here melting snow, rock, rotten ground, and slippery branches made as bad going as can be conceived, but it was not the old man who called a halt twice to get wind before we reached the ridge, but myself. We climbed nearly 
a mile along the ridge, downstream, and finally he posted me at a pass where he told me any pig or bear on the hillside was sure to cross to the other valley.

Before long I heard the voice of Duran encouraging the hounds, but it was not till they were about halfway up the hill that they opened. As the hunt continued my hopes of pig lessened, and presently it was evident, from the way the chase kept along the hillside, that it was a roe. Hounds were still running, when the old man left his post and came towards me, at the same time calling to Duran. This proceeding put an end to any possible chance of a shot, and after a final double upstream, the cry died away in the opposite direction. When Duran reached us he told us he had seen the deer-a fine buck with good horns. Altogether it was most provoking, and not the least part of the anmoyance arose from the fact that the hounds were gone. I had been sitting in the snow so long that I was chilled to the bone; but fortunately there was plenty of resinous wood about, so that we soon had a roaring fire going by which to eat our lunch. At the end of an hour Harmony turned up, but the rest of our proceedings that day consisted principally in hanging about waiting for hounds which never came. At last we descended to the Narenta, and Duran went back down it for a final 
search. We two turned homewards, flushing the woodcock in the same spot as we passed it. At the cottage I stopped to wait for my man. The son, his wife, and three children were now present, so the little room was pretty full. The goodlooking young wornan made no bones about my seeing her face, thus enabling me to judge how beneficial to the complexion the Turkish practice of covering it up is; for though, as I have elsewhere said, the village Moslem women do not, literally speaking, veil their faces, they cover them up so much by a kerchief round them that they are quite protected from the sun. Before long Duran returned, having been (falsely) told that the hounds had gone home; but nevertheless it was dark long before I had the cheery lights of the tent in view. Hounds only cast up next morning.

I have just mentioned flushing the first woodcock of the year.* A day or two afterwards I saw a couple more, and now devoted my attention to them, the weather being really too bad to do any good with the bigger game. The last week of the chamois season had come, but heavy rain

* I do not here refer to birds which breed in the district. This is a disputed fact, but I saw one bird in June, and later on picked up a.freshly dropped feather (both in the Velez). Captain Polatzek, who has collected in this district for years for the Vienna Museum, agrees with me as to its occasionally remaining in the Herzegovina to breed. 
was the order of the day - a most tantalizing close to the season. Woodcock-shooting, however, makes up for a great deal. It is hard to say wherein its great fascination lies, but it is the only small game that to most of us compensates for the want of bigger. Both banks of the river below Glavatičevo are ideal places for woodcock, but by no means for woodcock-shooting. The birds mostly lie in the high osier beds. (By the way, the natives seem to have no idea of the economic value of the willow, only using the shoots for wattle fences.) When flushed, the birds generally cross the river. Besides this, there are a number of islands, one a good acre in extent, which I have often had cause to anathematize when a flushed cock dropped among their bushes. To show the difficulties of the sport, on one day that I kept count I had two shots, one a long one, out of ten flushes. It must not be imagined that I could only flush ten birds a day, but, as a matter of fact, I only went out between showers, never for more than a couple of hours at a time. With a steady setter I could no doubt have done better than with dachshunds, which lose one many a shot by following birds which drop within a short distance. The weather, too, turned warmer throughout Europe very soon, and I dare say this checked the migration. At any rate, it only lasted 
about a week, though I picked up stragglers till the end of the year.

The amusements of camp-life in such weather as the closing days of October afforded are somewhat limited-especially when, as here, the said camp is a score of miles from a post-office, and the delivery of letters and papers is regular only in its irregularity. Under such circumstances one resource is the cuisine, and many were the attempts we made at new or untried dishes. At Glavatičevo we were somewhat handicapped by not being able to get any but the roughest supplies, even our butter having to come from Mostar. Nevertheless, we scored several decided successes, even if we did not quite equal our great discovery of the previous year-stone-hens stewed in hare stock. As I doubt if this bird is mentioned in any British cookery-book, I give a couple of recipes for cooking it in the Appendix. The year before we had reduced our travelling library to a minimum, one book, "Jorrocks," being selected by acclamation; but this year we relied entirely on periodical literature, and on our nightly game of piquet.

The large priest's house at Glavatičevo, which contains the chapel, is surrounded by what is here called an ograda, which means an inclosure fenced to keep out grazing cattle and sheep. Generally these ogradas are detached coverts, 
but this particular one consists of grass and arable land divided by two or three belts of brushwood. Lying as it does on a slope facing almost due south, it is an ideal place for hares, and $I$ found it most useful in this respect whenever a change in the menu was required. Having thus taken toll of the worthy "p.p.," as they would call him in Ireland, I thought I could do no less than send him a haunch of roe venison, especially as he had met us shooting over his ground a day or two previously, and he had then asked us to go up and see him. Duran, who took him the haunch, brought back such a cordial repetition of the invitation, that a day or two afterwards, on our return from a trip to the Visočica on which E- accompanied me, we walked over there one afternoon. Although a Bosnian, our host spoke Italian, having been educated at Bologne and Pistoja. This facilitated conversation, for my Slav at best was only equal to discussions with my "shikaris." He told us he had been in this lonely little place for ten years, his congregation consisting of only twentyfive families scattered over a very large district. As we chatted over a bottle of his excellent wine (grown in his own vineyard at Konjica, for these Franciscans do not take the vow of poverty), the question of doctors and medicine in these out-ofthe-way places came up. He modestly informed 
us that, though he possessed no great skill, the people hereabouts always go to him. "The other day," said he, "a Turk from Bjelemić (six hours away) sent an express begging me to help him, as he was very ill, and could keep nothing on his stomach-not even water. I diagnosed the case," he continued, "to be one of chill of the abdomen, and I sent the following message: 'Bake a barley loaf, and as it comes out of the oven cut it in two and wet it with brandy. Then pepper it well, and apply it as hot as you can bear it, one half to the stomach, and the other to the small of the back. Repeat this a few times, and you will be cured.' After the third application he was cured." I recommend the remedy to my readers if ever in like case when beyond the reach of a doctor or a chemist's shop. At all events, it sounds better than one which was sent me from the Lakat gendarmerie on one occasion when I had run out of opium, and sent to them to ask if they had any. After expressing his regret at having no medicines, the Wachtmeister added, "The best thing for choleraic symptoms is to take black coffee, and sit on a board." This remedy I did not try, preferring to send to Mostar for Dover's powders.

The good priest, who had thus shown a truly Christian spirit towards an individual Mohammedan, had, I am afraid, an honest Slav hatred for them 
in general, and was delighted when I told him of the Armenian agitation, then at its height, and of the pressure that was being put upon the Sultan. He himself sees no other newspapers but religious ones. But I think he had a still worse opinion of the Greeks, who, by the way, have their church and priest at Borke, four hours away. We exchanged visits several times after this, and, I may say, became quite intimate with the old gentleman, who wound up his civilities by lending $\mathrm{E}$ - - his saddle to ride to Mostar on.

Situated as our camp at Glavatičero was, between Church and Mosque, we had ample opportunities of observing the difference between the Moslem and Christian peasantry, and I regret to say that the result of these observations was by no means in favour of the latter. Of course both creeds are recruited from a common stock, and their dress is almost identical. But the contrast between the groups of villagers oue met going home on Fridays, clean, sober, self-reliant, intelligent, and cheerful, and those who reeled along on Sunday evenings dirty, at best semi-intoxicated, and boorish, was most marked. I certainly have no hesitation in saying that I always preferred to associate with the "infidel," and should be sorry to hear that the ultimate result of taking these provinces from the Sultan had been the foundation of a Christian State here. One Bulgaria is enough 
- perhaps too much. Happily, there is very little chance of this. No one who has lived in these Provinces, and in India, can doubt the excellent qualities of the Mohammedan, under a good government; but, unfortunately, no one who has travelled in Turkey can doubt the bad ones of the Turk as an administrator, or fail to see the crying need of Western supervision for the unfortunate countries under the rule of the Sultan. It is not the Turk who should be expelled from Europe, as Ariosto long since demanded, but the Pacha. 


\section{CHAPTER XXXIV.}

"To finish the season." Sad words for the sportsman. How often have I read them with regret following such announcements as "Grafton, Cowper's Oak," or "Kildare, Dunlavin"! But they may be applied to other forms of sport besides hunting; and the season must indeed have been a good one that the true sportsman can see close without regret, especially in a country to which he may possibly never again have a chance of returning.

The end of October-the legal close of the alltoo-short chamois season in the Herzegovina-was at hand. My poor friend Miller summed it up in a few words: "First half, too hot to move, sheep on all the stalking-ground; second half, rain and mist." There is much truth in this pithy summary, and in this year the season ended in a succession of wet days. On the morning of the thirtieth I woke to the patter, patter, of the raindrops on the outer fly of the tent; but when coffee had been despatched the rain had stopped, and, though the day looked desperately bad, I decided 
to try my luck, and, loading my indefatigable Duran with my "Breadalbane" mackintosh, in addition to my ruck-sack, I sent him for the hounds. Dorothy being hors-de combat from snakebite the previous hunting day, I could only take a couple, but these were reliable. Less than two hours' walk brought us to old Zaklan's kuća (house), and I proceeded to enlist his services and take his advice. The old man was far and away the best sportsman I met here, and reminded me to some extent of my Ceylon trackers. He never failed to find me game, though, of course, a single sportsman must be lucky to get a shot over hounds. I always let him have the little rifle I had used in Dalmatia, but he never hit anything with it. The mighty hunter of this country is not used to the bullet, a handful of slugs, nails, etc., being more in his line, and even then a standing shot must be obtained. This they get by giving a low whistle, which brings most animals to a momentary standstill.

On this particular morning there were several villagers at the house, and a grand palaver ensued. Meanwhile I will try and describe to the reader the nature of the ground where it was finally decided to hunt, the old man having seen chamois there recently.

The streams of this district, towards their confluence, resemble in plan, roughly speaking, a $\mathrm{K}$ 
laid on its back, thus $\overline{\mathbf{Y}}$, the lower stroke being the river Narenta, the left-hand one the Rakitnica, and that to the right the Grušca brook-an affluent of the latter river. All three flow through terrific gorges, which rise in places thousands of feet above the water. In the acute angle between the Rakitnica and the Grušća is a grass slope studded with fir trees, where I was assured no human foot, no sheep or goats even, had ever trod, the chamois being the only living thing ever known to go there. The hills between Narenta and Rakitnica (below their confluence) are, as I have already said, called Chepa, and are separated by these waters from the higher mountains. Nevertheless, in late autumn the chamois work across them, and, when disturbed, generally return whence they came. Here they had been seen. The plan of action, then, was that I should go along the Rakitnica as near as possible to the confluence of the Grušca, whilst the hounds drew the almost precipitous cliffs opposite me. In case of a possible break-out along that bank, old Zaklan with the little rifle went on to act as a stop. We started off in opposite directions, Duran and I being each accompanied by a villager to act as a guide. My way lay over the ridge behind Kasiči village, and down thence to the valley of the Rakituica, whilst all the others crossed that stream by the bridge. The gorge was easy to reach, but then followed 
some miles' weary climbing. The entire hillside is one (wooded) moraine, the loose stones being covered with dead leaves and sticks, but absolutely without one inch of sure foothold, except, of course, here and there on the root of a tree. I found this much more trying when returning back upwards, but I put in one fall each way, each resulting in considerable abrasion of cuticle at elbows and knees. After some two hours, nearly half of which time we were halted, my excited guide pointed out a chamois on the tremendous cliff opposite, but, not having my glass, I failed to locate it. Presently I heard Duran cheering the hounds, but the roar of the torrent drowned their music. After a bit the little rifle rang out twice, and we hurried on.

I had just got to a place where I could see a little, when my companion spotted another chamois - a large dark beast, evidently a buck-coming straight down opposite, a fine sight. "Here comes one! here comes one! here comes one!" he kept on; and, remonstrance being quite unavailing, I at last put my hand over his mouth. Meanwhile the buck had disappeared in the thick wood which fringes the stream. The roaring of the swollen stream prevented my hearing him cross, but when some minutes had elapsed, I knew he must be near us, and to a certainty standing and looking back for the dreaded hounds. I saw 
my companion beginning to fidget, so, guessing the animal would fail to locate the origin of the sound correctly, I gave a shrill whistle.

Directly afterwards the buck dashed straight towards me. As he was making for thicker covert, I dared not pause, but snapped at him at not more than twenty-five yards' range. He turned a back somersault, and then struggled to his feet, I giving him a too-hurried and ill-judged second barrel as he did so-a miss, of course. Before I could reload he moved off, but I caught another glimpse of him going slowly through the bushes. Of course my Turk rushed off in pursuit, and the result of this was that in a few minutes I saw him (the chamois, I mean), very sick, but nevertheless. able to climb a cliff to my right rear. Although the distance was a bit too far for my weapon, I sent a bullet after him, and then-he was gone. My shots had turned another, which I saw going up the slope opposite again; and I heard a third whistle, but failed to catch sight of him, though I came on his tracks presently.

A few minutes later a roe ran right into me, but it was a doe, and of course I did not fire. When I was satisfied that there was no further chance of sport, I proceeded to visit the scene of action. To my surprise and disgust, the first thing I saw on the ground was the lens of an eye, with the liquid from that organ, but not much 
blood. My Turk brought me a stone with a good deal more on, but in my opinion not enough. I feared the bullet must have cut the eye out and just scored the head. Still, it was unlikely the beast would go far, so when Duran turned up with the hounds I ordered a pursuit. I was taken-a desperate and dangerous climb, the men going barefoot-to a saddle of rocks between the place where I had fired and the Grušća brook. Then the men continued the search, refusing my offer of the hounds, which they said could not follow.

At the end of half an hour I heard shouts, and made out a single chamois going slowly on the other bank of the Grušća. When the men came up they said it was mine, aud that he was very sick. The mere fact of his not having gone up from the water proved this. I wanted to follow again, but they said it was impossible to cross from where we were. Moreover, the sun-for the afternoon had turned out fine-was getting low. Reluctantly, therefore, I commenced the long climb along and up the hillside, which seemed as if it never would end; but at last we reached Kasiči village, and found old Fezo had got back before us. He had only scored a couple of misses.

Hounds, I was told, had hunted splendidly, but I neither saw nor heard them; but the result of their efforts satisfied me as to the correctness of Duran's statement. At first I was inclined to 
return next day to prosecute the search for the buck, but on reflection I saw that I should only be a hindrance to the Turks, besides being pretty tired at starting, after my long day. So I left Zaklan the rifle and half a dozen cartridges, which he returned when his son came in to the mosque next day, saying he had failed to find the buck.

A few days later, when on the look-out for pig spoor, for which I had promised a good reward, a gathering of vultures attracted his. attention, and resulted in his finding the dead animal. Of course the carcase was partly decomposed, for a buck chamois in the rutting season will not keep a day unless the curious glands * behind the horns, which are then so swollen and offensive, are at once cut out. Nevertheless, I got my horns, and the assurance that the bullet, after cutting out the eye, passed through under the flank. Making shots of this kind is most unsatisfactory to the sportsman, but I can urge that this was the only chamois $I$ hit and failed to kill clean during the season. The fact is, I should have done better to load with $\mathrm{BB}$ shot in the right barrel on these occasions-a shot-and-ball gun being so well adapted for this. To make sure of suapshots at short ranges takes a first-rate

* The Austrians call these the feigen, or figs. They derelop in the Herzegovina earlier than elsewhere, i.e. in the last week of October. 
rifle-shot, and $I$, alas! have never even claimed to be classed as second-rate.

This was my last day of chamois-shooting over hounds - a form of sport which I began by despising and ended by liking, as so often happens. At all events, it has several advantages over driving, the principal one of which is that the old bucks, which lie close and break back through beaters, are the very ones with which hounds get away on good terms. More chamois are killed in this way in the Herzegovina than in any other, and I consider it an excellent method when there are no precipices in the beat, for the antelopes invariably resort to these, and then defy both hounds and rifles. A chamois found well away from the mountains, as these were, would give a grand run to a pack of hounds, but there would be very few of the field up at the finish!

So ended the chamois-shooting. The bears (one of which I had received a message from Umolanj, six or seven hours away, to come and kill, as he had been destroying the people's cattle for six years) had all gone into winter quarters, and nothing remained to be shot but boar and roe. One day at these latter is so like another, that I think a description of one, perhaps the pleasantest I had at Glavatičevo, may fairly stand for all. 


\section{CHAPTER XXXV.}

THE sun was struggling with the dense white mist as I drew up the door of the tent at about halfpast seven. Here, down by the river, its rays had not yet penetrated, and the grass was still white with rime, but that hillside which faced east was bathed in sunshine. The air was keen, and the thickness of the ice on a bucket outside the door proved that the frost had been sharpish. I was glad to return to the genial warmth of the stove, which Duran had lighted half an hour before. By the time I had despatched my breakfast the sun had cleared off the mist, and I started off with one hound, Dinah, in leash. After crossing the bridge I was again in shadow, and felt glad enough of a thick kilt and shooting-coat. I struck off up the Razića valley, opposite my camp, and followed a hill path which kept on crossing and recrossing the meandering rivulet. Half a mile up I passed two exceptionally large Bogumilite tombs, on which, however, no sign of carving was visible. I did not meet a soul on my way, and after a little more than half an hour my path led into a dense 
covert. As I crossed the stream for the eighth time, I passed a tumbledown mill to my left; few of these mountain streams but have one or two, to which the mountain villagers bring their corn many miles. Even the Lakat villagers come all the way to Glavatičevo for this purpose. This one, however, was deserted this morning. As we gradually ascended through the woodland Dinah got a whiff or two of last night's drag, probably that of a hare, and became less amenable to the leash. However, she had to restrain her eagerness a good bit yet. At the end of an hour's sharp walk, a convenient fallen tree invited repose, so, tying up the bitch, I sat down and filled a pipe. Before it was smoked out Dinah had become very restless, and finally broke out in a whine, by which she meant, "How much of this beautiful morning are we going to waste like this?" A beautiful morning it was, certainly, for there was not a cloud in the sky; nor was it cold, even down here in the glen, where the sun had not reached, and probably never did reach. Not much like the middle of November to-day. We continued our way, and where a little mountain torrent-now dry-had made a side valley, the dead leaves, elsewhere white with hoar frost, showed a black spot. A roebuck had been turning them over since the frost, as Dinah's waving stern testified. Very well, especially as it was at this very spot I had meant 
to leave the track. I commenced the climb of the ridge between the main and side glens - a somewhat arduous one, and rendered no easier by the fact that the drag seemed pretty strong here, making the bitch decidedly troublesome to lead. However, up I went, and passed the covert limit to enter that of the pines. By this time I was warm enough, in spite of a cool wind from the southward, and was glad to unbutton my coat, and to pocket my neckhandkerchief. At last the climb was done, and I reached what German sportsmen call the wechsel. We have no word for the regular, though often invisible, path four-footed game follows; * albeit the fact of there being such a thing must have been known to old-time Englishmen, for Horace alludes to it, and I dare say Xenophon too. (If they had only, in our schooldays, let us construe the hunting part of his works, I dare say I should have made more progress therewith than I ever did with those wearisome "Ten Thousand.")

"Now go, Dinah, and see if you can find one of those brown-coated little gentlemen, lying where the covert is thickest, and peacefully working his little white lower jaw backwards and forwards

* On Exmoor, the places where the red deer pass, especially through the close high beech hedges, are locally known as "deer racks." These, however, are visible enough, though to the uninitiated they appear very small for the size of the animal that makes them. 
under his black velvety muzzle, till the provender collected during his morning's foraging is all duly disposed of. And, having found him, give him no peace till he crosses the ridge. Now, hie in."

The bitch, however, shows little desire to go. The drag all round here is delightfully fresh, and she revels in it for some minutes. Round and round she circles, her stern lashing her sides; but at last the circles grow wider and wider, and she disappears from view. More and more faintly the sound of the bell on her collar reaches my ears, and at last dies away. All is still. Relatively, that is, for far up the main valley I hear the sound of an axe. In two directions cattle-bells break the silence, and still further away the monotonous droning of a herd-boy's pipe sounds among the hills. It sounds exactly like those used by the Indian samp-zullahs (snake-charmers), and carries my thoughts back years, to the days when we sat sweltering in the verandah to pass half an hour by watching what we had seen a hundred times before. I can see it all now, the almost nude figure, with his cobra half erect and moving in unison with his movements, the crowd of whiterobed servants at a respectful distance, theHark! the bell-like tones of the hound break the day-dream off short, and I turn cautiously half round so as better to command the passes. There are two of these, a fact which stern experience has 
taught me, for iguorance of the fact lost me a buck here not long since. One runs just above me, the other diagonally below, but both are within easy range. The bitch found not far a way, but no doubt some waft of the treacherous south wind has betrayed me, for the sounds descend the hill, and then cease. The deer has utilized the brook to kill the scent. Dinah can be trusted to make her own casts, though, and in a very short time she is merrily tonguing up the opposite slope, and is soon above the covert fringeing the stream. It is open enough up there under the great pines; I ought to get a view. Carrying my eyes off to the left, I do. A furlong ahead of the hound a roe is racing along a wood path, and as I think, and hope, a buck. At the distance I can see no horns; it would bo too cruel if he had cast them already. He turns downwards, and the covert swallows him. High time, too, for the bitch was gaining; and she too makes the downward turn without hesitation. When she reaches the brook her voice ceases; the deer has "beaten the water" again. Perhaps he is coming up! I strain my eyes in vain; and this time the check is longer than the first one. At last the music breaks ont again, behind me this time, in the side valley. I have barely turned in that direction before I hear a stone rolling, and the sound guides my eyes to the deer. The hillside is so steep that it moderates even his pace, 
and I can scan him (for it is a buck) carefully. His horns are all right, and of fair size.

On the ridge he pauses one fatal moment to look back. Bang! The hills re-echo the report, and the buck lies kicking. I hurry towards him as soon as I have reloaded. Poor fellow! but euthanasia soon follows. As my skean dhu finds the fatal spot between skull and vertebra, the soft eyes glaze at once.

The other day I was reading an article by Mr. Andrew Lang, in which he says that as the sportsman grows older "he ceases to be sanguinary." If this is true I never can have been young, for, with the exception of actually noxious and dangerous animals, I think I never killed one without some slight feeling of regret. A cock pheasant, for instance. There he lies, a crumpled mass of feathers, that a minute ago was a beautiful and harmless creature, enjoying his simple life. What right had I to take it? What_— "Mark," and the gun is at the shoulder again, for the sympathy, alas! only comes after the shot. A hunted fox again. Well, there I think I can honestly say I never tallied one in my life when another man was carrying the horn. Poor beast, he has given me a capital twenty, thirty, or forty minutes; let those whose business it is view him for themselves, if they can't kill him without. If I were hunting hounds, my feelings for them would 


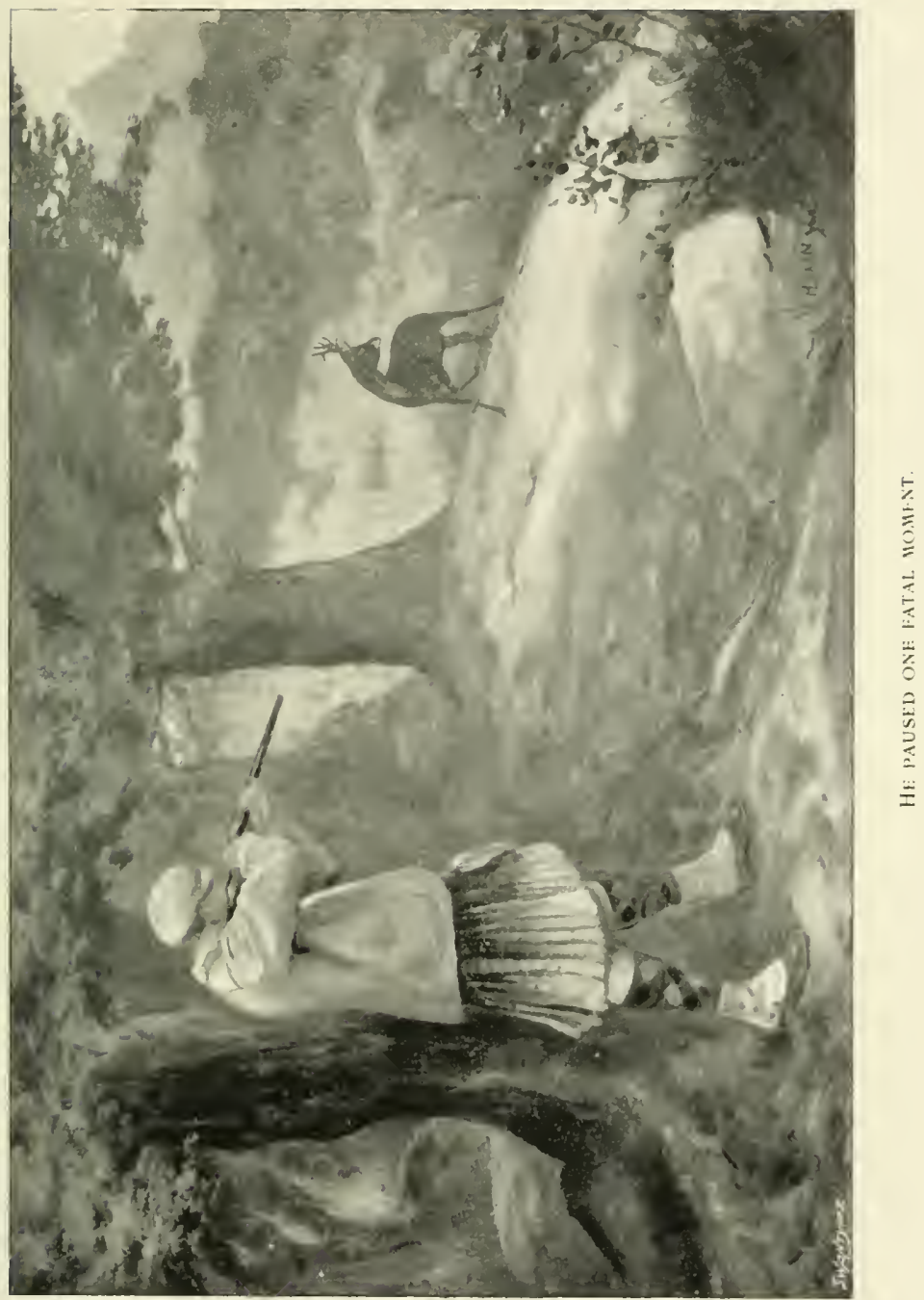



prevent my sparing him, but that is quite another thing. So he slinks off in peace; but I fear I should be the first to cry, "Beautiful!" if the eager bitches hit it off by themselves. I should have hesitated to make this avowal, perhaps, if I had not seen in the Field the other day a similar confession by one of the most gifted of the hunting correspondents of that paper, the "Phantom" of the Belvoir. But with the deer tribe this feeling must, I think, always be strongest, and with the little ones most of all. The smallest I ever shot, which has a Latin name much longer than himself, * is known in Ceylon as a "mouse deer," but he is rather larger than that animal, being, in fact, when full grown, as large as a hare. But of European animals the roe, in my opinion, is the most deserving of sympathy, and fares worst of all, being mostly shot with a "scatter gun," even in Germany, where the maxim, "Zum Wild dasz auf Schalen geht, gehört die Kugel," † obtains.

Meanwhile Dinah has come up, and is snuffing the buck all over, but not offering to touch it, never having been blooded, and apparently hunting none the worse for it. I take up a fore leg, and make an incision above the knee sufficient to draw the extensor tendon through, and pass the other

* Tragulus Stanleyamus. Seo Appendix.

$\dagger$ "For game with hooved foet

The bullet is meet." 
fore leg between this and the leg itself. The laws of woodcraft dictate this procedure with a roe, whereas we "harle" a hare or rabbit with the tendon of the hind leg. I must confess nothing delights me more than this old science (so neglected in England), with its quaint customs and maxims. Why, for instance, should the man who is dressing a stag never step over it? It is easier to understand the maxim that, if royalty is present, he must not remove his coat or hat, though this, too, must make the job anything but pleasant on a sweltering autumn day.

The buck-a six-pointer, by the way-is a heavy one, and I am quite satisfied when I have hung him on a pine tree conspicuously, so that Duran will find him without difficulty later on. I sit down in the winter sun to get my lunch, of which Dinah gets her share. When we have finished, I light my pipe and enjoy the splendid view.

The valley at the side of which I am resting, like most of those hereabouts, ends in a punchbowl-shaped hollow, bordered with fine pine-clad cliffs. Above these is the main range-sheep pastures in summer, but already given up now to the wolf. As far as I could learn, the chamois never come to the Razića valley in winter; probably it, and also the next one lower down, Dudle by name, are too small, and too often disturbed. As the valley broadens out below its sides become 
cultivated in places, and flecked with huts here and there. Then comes the main valley, and beyond hill above hill, culminating in bare forbidding-looking peaks. Bare as they look, there is pasture enough up there, and it is to them that the European antelope withdraws during the summer heats. A lovely land, yet unlikely to become a tourist resort for many a day, considering that not even a good bridle road yet traverses it.

But the winter sun is declining towards the west; we must be going. "No, Dinah; sufficient for the day is the buck thereof. You shall not disturb the other

'Native burghers of this desert city

In their assign'd and native dwelling-place ' to-day. Come to the leash."

So we go quietly homewards. The woods seem more silent now; only the curious cry of the great black woodpecker breaks the stillness. These neglected woods are a very paradise for all the varieties of this bird. See, there is a lesser spotted one at work. His red head hammers away, and as he turns the branch he shows the same brilliant scarlet underneath. He has not noticed me yet, but as I step forward he does so, looks down, and calmly continues his work. His bigger brother would have alarmed the whole parish. As I pass 
a fir tree I stop to pick a green tuft for my cap, following the quaint Austrian fashion of successful sportsmen. Half an hour later I am at home.

To my mind no sport can be more delightful than this combination of shooting and hunting. Two things only are necessary. Firstly, the knowledge where to stand. This the natives of every country can tell one, for there is no village in the world but can produce some fellow with that instinct that makes the poacher (I mean the rustic, not the professional variety) in England. The second desideratum is the hound, which must draw well and wide, but perseveringly and musically, and lastly return to his master after a blank draw or an unsuccessful chase. This last is easily taught, but involves the wearisome job of waiting (hours sometimes) for the youngster you are entering. Go home without him, and sooner or later he will return the compliment. As to the breed of hound, the nature of the country in which you hunt must govern the selection. Small woodlands and easy ground involve small hounds, dachshunds for choice, but it is so rare that they will draw wide enough, and many are not musical. Here they would never do, for, apart from the difficulties of the ground, the wolf has a habit of joining in such a chase, and many a beagle has been lost in this manner. Some people use a couple of hounds, 
but my experience is against the practice, for, if the hounds separate, one may be between you and the deer, and "blanch" him as he is coming straight to the gun.

Now, at the risk of being called a man with a single axe to grind, for I have so often mentioned the matter in print before, may I ask why should we not be able to enjoy such sport in England? No animal is easier to introduce into woodlands than the roe, which is not destructive to any extent to crops, and which would form an important factor in our supply of game. As it is, very few ever find their way to the London market, and most of these come from abroad. It only involves the matter being brought to the notice of our larger landed proprietors, and the co-operation of smaller ones. The roe is a native of our islands, and if people can be found to attempt such expensive and questionable acclimatization as that of the wild turkey and Patagonian hare, why should the little deer be neglected? I have never heard any argument but one used against it, and that is that the presence of roe in coverts interferes with fox-hunting. The answer is simple. There are plenty of roe in the Blackmore Vale, perhaps as good a provincial hunting country as can be found, and plenty of deer of all sorts in New Forest, where till recently foxhounds hunted four times a week, and still 
do thrice. In fact, one might just as well say the presence of hares interferes with fox-hunting.

The winter at Glavatičevo may be taken roughly at two months behind that of Lakat, for the snow of October 20 was quite unusual and transient. The first night frosts began in the middle of November, and a week later the weather was severe, the earth bound in an iron grip, and all the surromnding hills white with snow. Now indeed our Yankee stove was a comfort; indeed, as I have before said, if we had any fault to find with it, it was that its heat was too great for a thirteen-foot tent, but, except when cooking, this could be regulated.

I lingered on in the hopes of getting a boar, and made expeditions in various directions with this object, too often to be baffled by the sight of sheep or cattle in my proposed ground. The boar loves quiet, and is assuredly not to be found where flocks and herds wander. Nevertheless, I did not regret the time thus spent, for many a lovely view, at all events, repaid my exertions. For instance, it was thus that I learnt to know the bold waterfalls of Dhužani, which would be lovely but for the bareness of the rocks amongst which they rush in a tremendous zigzag. I have no doubt had I been able to try the long slope of fir woods which runs along the left Narenta bank, high above the stream, between Glavatičevo 
and Borke, I should have found what I was looking for, but that is included in the Government reserve.

At last it became evident that, though we could keep our tent warm and comfortable, it was only by the side of the stove that any pleasant existence was possible. The bora, too, blew keenly, driving before it flakes of snow, and the borc is no joke when once the thermometer is, as Mr. Jorrocks would say, "down to fecit." We must think of once more laying our heads under a roof. In my opinion it speaks volumes in proof of the healthiness of a life under canvas that in these two years, with every varying condition of weather, neither of us had suffered in the least degree from colds, though, as a rule, we are both rather subject to that affliction; and both, I may add, contracted them within a week of recommencing civilized existence.

So, after a number of days spent in that anything but pleasing manner, standing motionless in the snow for an hour at a time waiting for a boar which never came, I reluctantly agreed with my better half that the time for camp was over.

But after all it was not cold, but heat, that forced us to strike our second Herzegovinian camp. A little before the middle of December the wind chopped right round. For serenteen days we were treated to a gale of wind (scirocco), rain, 
hail, thunder, and lightning. Needless to say, the river began to rise at once. For six days the rains and the melting snows swelled it to a turbulent torrent, and every morning it was nearer and nearer to our tent. At last the commander of the gendarmerie post sent down to warn us of the danger of remaining any longer where we were. At that hour, however, the river had ceased to gain on us, and I went to bed with a reasonable hope of a quiet night. Happening to wake up at half-past one, I slipped on some things, and took the lantern for a final survey. Horror! it had risen two feet more, and was within that of us. I aroused E-C, and, leaving her to dress, went off to the village in search of Duran, who soon came accompanied by another Turk. As the best plan, we decided to take refuge in the barrack, leaving the men to watch and call me if necessary. But the necessity did not axise, and when I went down next morning they showed me the high-water mark, two feet from the tent on the shelving bank, and vertically perhaps four inches. This was not good enough, so camp was at once struck.

The best plan, no doubt, would have been to trek to Mostar there and then, but the tent, wet as it was, was too heavy for any horse. We selected a fresh site a hundred yards further back, and I may mention, as a proof of how adept 
we had become at pitching, that in less than an hour our lunch was cooking in the new camp. The reader, I am sure, will not require to be told that after this the river at once began to fall, and though the rain continued for another three or four days, the water never reached our old camp site at all. That week was a dull and depressing experience, which any one can imagine when I say that the winter climate at Glavatičevo is as like that of our own beloved island as possible. We longed for two fine days-only two, one to dry the tent, and another on which to move-but we longed in vain.

Shooting, too, was impossible in such weather, but one day I did steal, and not a bad day either, so perhaps it deserves a fresh chapter. 


\section{CHAPTER XXXVI.}

"I THINk we ought to have some game for Christmas," said my wife to me three days before that festivity. To which I dutifully replied, "Very well. I'll go to Kasići to-morrow." The morrow was not an inviting day, there being a Scotch mist with frequent showers, but on the whole I thought it would do, so started kennelwards about ten o'clock with Duran.

"Turn them all out, Pigg," said Mr. Jorrocks, on the morning of the ever-memorable day on which he "pivied the old customer," and incidentally lost the seat out of his breeches also; "we'll have a good cry, at all events." Acting on this principle, I turned out all mine-a couple and a half of beagles, and as many dachshunds. By so doing I committed a breach of the law, but I can plead, like the immortal Master of the Handley Cross Hounds, that it was my last day of the season. When the beagles were coupled, we started off. Our pace that morning was not improved by the dachshunds, who were very keen, and kept on disappearing on hunting 
expeditions of their own. However, about halfway, Fox, a puppy that had hitherto been what the above-quoted authority called " a sleepin' partner of the chase," wandered into an irontoothed trap, and I think his dolorous yelpings diminished the ardour of the others for a bit. I ordered Duran to annex the trap, which we handed over to the headman of the next village to take to the gendarmerie, and we arrived at our happy hunting-grounds without any further mishap.

I have already described Kasići, but I ought to add that above the road the ground is rocky with thorn bushes; below it, varied, part arable, but mostly: grass with little patches of covert and stiff fences, and, facing as it does due west, it is an ideal place for hares.

Hounds, being uncoupled, began to feather at once, but whilst the beagles worked to the right, the little hounds kept nearer to me, and in less than five minutes I heard old Rex's "yap, yap!" I ran forward, but I suppose not far enough, for when the hare broke she took off the contents of both barrels, and made off up the hill. I followed the hounds for a bit till I found them checked, and, a boy telling me they had gone right up the peak, I coupled up the beagles and went back. Seeing the dachshunds feather in a tangled bottom, I released the others, 
and all crossed to the opposite slope. In a minute Rex-mute except on the hottest of scent -opened again, but I saw nothing. Meanwhile Fox had returned as usual to my heels, but for once not to stay there, for he went back behind me, and not half a minute later he also openedfor the first time in his life. Turning round, I saw him coursing a hare straight to me; in fact, I had to wait till she turned a bit, or I should have had the dog in line with her. Bang! bang! and she disappears in the bottom. Two double misses, the last at twenty yards' distance, puzzle me altogether; but it must be so, for the boy is shouting that he saw her go down the field beyond the bottom, though hounds have all gone to the little thorn covert where Rex opened last. I follow them, and am relieved to find Fox and Dorothy tugging at the hare. Who-whoop! All up except Harmony, so I proceed to blood them, principally for the benefit of the puppies.

It is now evident to me that the hare which the lad saw going down the hill was Rex's second find, so when Duran comes to take the dead one, we go off in pursuit, picking up Harmony en route. A furlong further on I meet an old Turk, who politely informs me that he saw the hare go into the little covert just below us; so I cast the hounds on. The information was correct, for Harmony was soon "tonguing in a whisper," 
as she does when the scent is not quite fresh enough; bursting with the restrained desire to throw her tongue, she emits something like a stifled whimper. But the hare had a long start, and it was only a coldish line that hounds could pick out down through the brushwood, across a muddy lane and field beyond, through another covert, and finally across a field of young wheat to a rocky mound covered with thorn bushes. Here, after a quarter of an hour's patient trying, I gave it up and went on. But before I had gone a couple of hundred yards, Dorothy's deep note recalled the others. I splashed up a filthy lane, and by a cattle-shed I met old Fezo Zaklan, before referred to. Before we had finished kako te-ing, ${ }^{*}$ the hare left the rocky hill and crossed by the other end of the shed, the two puppies, who had probably caught a view, coming neck-andneck full cry behind. I was across the lane, and round the thicket above (studded, by the way, with Bogumile gravestones) in a minute, but the little fellows were already away on the far side. (The question as to drafting "Fox," which had been exercising my mind for some time, was answered in the negative by now.) The hare, however, had run through a flock of sheep, which checked the puppies, and let another couple come up. The girls shepherding pointed out a biggish

$$
\text { * Kako te }=\text { How are jou? }
$$


brake which the hare had entered, and as she had been on foot three-quarters of an hour, I thought it was about killing time; so, giving the hounds over to Duran to put in on one side, I went in to stand at the other top corner. In a minute or two I heard hounds running, and, as I had expected, the hare made upwards, and met her fate in the shape of a charge of No. 5. Dinah and Dorothy must have got on to a fresh hare at the bottom, for they were still absent when we adjourned to Fezo's house to eat our lunch.

It was raining hard when we had finished, so we lit a second pipe till it cleared, when we recommenced operations above the road, Dinah having just cast up. This enclosure was a long and thick one, and when they found, as they soon did, they went away at the far end, the dachshunds being left behind. I kept along the rocky hillside, thinking that the hare, which had gone almost down to the river, would turn back to me. Presently a dachshund ran right into a covey of stone-hens, which ran out of shot, and scattered in all directions. One came back, and as I got a little nearer, the dog flushed it again. The first barrel failed to stop it, but at the second it screwed its head back, and I kept my eye on it. When it had gone about a hundred and thirty yards, it collapsed and fell exactly into the path. 
I shouted to Duran to retrieve it, and went on, calling the little pack to me.

A hundred yards further on we came on the scattered birds. The first to rise had too much steam on for me, I suppose-anyhow, it went on ; but the second, which tried a short flight in front of a dog, was duly gathered. Number three ran chuckling before another puppy, got just above me, and then, rising, twisted right over my head. Small wonder I missed him, for I never had a more awkward chance; but he had a second shave, for a fine falcon, quite unheeding the report of the gun, stooped at him. The partridge dropped shrieking, but in safety, among the thorn bushes.

The firing had brought Dinah and Harmony on the scene; but they, after snuffing about a bit, decided that they were not on in this act, and disappeared again. I tried on for another hundred yards, moved no more birds (no wonder this, for the stone-hen is a bad runner at any time, and a big hawk wheeling overhead is not likely to improve matters), and then descended to the road, and turned towards Kasici. I had not gone very far when the cry of the beagles reached my ear. They had got their hare on foot once more in the bottom. I stood fast.

My expectation that the hare would cross the road was not disappointed; nay, she did more, for 
she actually ran along it towards me, not noticing me. She must have seen me put the gun to my shoulder, I suppose, for as I pressed the trigger she wheeled downwards, and got what was meant for her head a good deal further aft. Still she rolled rather than ran, down the slope, and I shouted to Duran to go and pick her up. But she was not to be found. With hounds all round her, there was no question as to her being gone, so I went in myself to point out where $I$ had seen her last. Hardly had I done so, when, on little Vixen's putting her nose into a thorn bush, out she jumped. Knowing she could not go far, I withheld my fire, and away they went, all three couple (for Dorothy had at last cast up), scoring to cry in every variety of note and key. I regained the road, and scuttled along, Duran crashing through the bushes below. A hundred yards on I heard her cry; the music ceased, and when I reached the spot every hound was tearing at her. However, Duran rescued her with the loss of her scut and a little fur, and we went towards Lower Kasići for a last draw. As usual we soon found, but the hare went away at the bottom, and along a lane right through the houses. A terrific hubbub and barking of curs ensued. All the hounds were driven off the line except Dinah and Dorothy; but they were not to be discouraged, and a few minutes later I could see them circling right round 
the summit of the conical hill above the river, Dinah's white spots and shrill note making her conspicuous in the van, whilst Dorothy's darker saddle-mark showed in the rear. It was evident there was a rare scent, and I had little doubt they would drive her back in time; but, unfortunately, I had a particular reason for wanting to be at home early. The only thing I could do was to hand the gun to old Fezo, telling him to wait in the saddle to try and shoot her, so that the hounds might start for home. This he afterwards said he failed to do; at any rate, the hounds were out till nine o'clock that night-four hours and a half after myself.

On Christmas Eve the weather held up for a few hours, enabling us to make a short expedition in search of decorative evergreens. Holly, of course, was not to be had, but we managed to get some ivy, and, above all, plenty of mistletoe. This plant seems not to grow on fruit-trees here, but sometimes, as I have before remarked, on the stone pine, and mostly at Glavatičevo on high thorn trees. The business capabilities of their thorns I had painful reason for being able to speak to after getting out two or three clusters, none of which grew less than ten feet from the ground. Of these one was magnificent-a perfect sphere two feet in diameter, and covered with berries. Such a bunch would fetch gold in Covent 
Garden Market. It went up in the apex of the tent, and the other greenery made a very effective decoration in combination with the roe and chamois horns hanging on every rib of our canvas home.

Christmas Day was even more abominable than its predecessors. The scirocco wind blew hard, with some extra terrific gusts, and the rain never ceased. In fact, a worse day I don't think we ever had in camp. We could only comfort ourselves by commencing to make arrangements for early departure. Christmas fare, as known in England, was not unnaturally conspicuous by its absence, but our old Dalmatian specialité-stone-hens stewed in hare stock-made us some amends; and at night we toasted "absent friends" in mulled Konjica wine, which, when good, I personally prefer to the more fiery product of the Mostar grape.

I have already said that in this camp we had no visitors-except, indeed, the priest, and the local officer of gendarmerie, when on his monthly round. On Boxing Day, however, just after lunching, a little man appeared whom I had never seen before. He was dressed in a grey suit and high boots, and on the left side of his round grey cap he wore a tuft of black feathers. By way of brooch, these were held in place by a strip of black cardboard bearing the inscription Nouveautés in gold letters (obviously cut off a wall card or 
box). This was secured with two brass paper fasteners.

I incontinently put him down as a wandering lunatic, but he introduced himself as a travelling tailor, working at the gendarmerie barracks, and solicited an order for a suit. I need hardly say I did not close with this offer, which refusal did not prevent his shaking hands effusively and saying that he was very glad to have made my acquaintance, and to have seen the tent. After he had gone we had a hearty laugh at our queer caller.

At last, on the evening of the 27th, after a fortnight's continuous wet, the longed-for change came. It came in the shape of one of the fiercest boras we had seen in camp, combined with the hardest frost I have ever seen in twelve hours. Our new camp was less sheltered than the old one, and the wind split up the outer fly, scorched as it was by the fires of nearly four months; but its work was ended, and we could afford to laugh at the mishap.

Camp was finally struck on the morning of the 29th ; and whilst I was in the act of superintending the operation, I received the news of a sad and quite unexpected bereavement, which, in any case, would have put an end to a pleasure trip.

So we started off on our return journey sadly enough, winding up and up the steep hillside below Glavatičevo. When we had nearly reached the 
top, we met a Turk so comically muffled up that, in spite of my feelings, I felt inclined to laugh. But before long the laugh was on his side. It was not till we had reached the upper part of the first pass we had to traverse that we realized how strong the bora was, and then for the first time I understood what a bora in the mountains with the temperature below zero meant. To say that it went through one's clothes as if they had not existed gives one no idea of the fearful bitterness of the blast. Poor E- fairly cried with cold, and no wonder, till I made her get off and walk, and from choice she performed a great part of the journey on foot. The worst of it was that all our furs and thickest clothes were in a Mostar warehouse, providing, as we subsequently ascertained, a sumptuous repast for the moths.

All things come to an end, however, and, as fortunately the wind was behind us, we traversed the second bare and rocky pass at last, and struck a new road winding down the other side. As we descended we felt the wind less, but, on the other hand, the sun had set, and the temperature consequently was lower than ever. At the bottom of the hill we emerged on the Zimalje plain, and were once more on familiar ground. Cold and weary was the climb up to Ruiste gendarmerie barracks that night; but we were expected, and a room with a roaring fire was ready for us. Not till then 
did I really realize what the cold had been, for the pain of returning circulation to one's ears, hands, etc., was almost unbearable. However, before our dinner was ready we were better.

Next morning we were off before half-past eight, only to repeat the same experience in the Ruiste Pass. I pushed on until I reached a building at the bottom-a cattle-shed it turned out to be. I soon persuaded the boy in charge of it to evict his beasts, and by the time $\mathrm{E}$ - - arrived I had a fire burning up. Our men, of course, wanted to go to a han in the next village, but I pushed on to Mirićhan, where we lunched. It was strange to hear, as I did from a lugar* who happened to be there, of the death of my poor friend Miller at the very spot where we had rendezvous for several sporting expeditions-notably for the bear-shoot at which the Archduke was present, when the arrangements were principally made by him. An hour or so later we reached the Hotel Narenta at Mostar.

As on our first arrival in the capital, a fierce bora was blowing; but this time it continued to do so for thirty-three days (with the exception of one which was wet)-rather a sickener. As soon as we were settled, our faithful Duran left us, and parted with tears on his side, and without counting the money I gave him-an unheard-of trait in a Herzegovinian. I own I was sorry to lose him, * Forest-keeper. 
but of course, as he had a wife and child, and probably a sheep and goat or two, at Razice, he had to go. Before going he called me moj otac (my father) -an imagery exactly like that of the Hindoo who sometimes in a similar case addresses his employer as mabap.

We found Mostar much changed during our few months' absence, and many of our friendsprefect, sub-prefects, soldiers, and civilians-were gone. There were physical changes, too, in the shape of a fair number of new houses, and even of a new road. But these were to be expected. Our own stay was only to be a limited one, and there was so much to do that there was little time for sport. A fox-hunt or two, and a few hours at the snipe and woodcock with the good friends between whom I afterwards divided my little pack, comprised the whole of it.

By the end of January our arrangements were all made, and the closing scene of our Herzegovinian experience-the assembly of the few friends left in the place, the companions of many a hunt and many a cheery evening in the garrison casino, round our railway carriage door-took place on the 31st.

Before our train had crossed the frontier our tongues had been busy with the past-a pleasant retrospect indeed-and we had both agreed that for good fellowship, hospitality, and kindness to strangers, the Herzegovina would indeed be "bad to beat." 


\section{PART III.-DALMATIA ONCE MORE. 1896.}

\section{CHAPTER XXXVII.}

That night we were once more in Metković, where we found a brand-new bridge across the Narenta. I fancy the natives had hardly got used to it yet, for they brought our luggage across in a boat. Worthy descendants of the old Narentine pirates, they endeavoured to get half a sovereign out of me for this service, but failed signally. The little Café Europe had changed hands, greatly for the worse. Although it was very cold, the landlord absolutely refused to heat the café, and I don't think I ever felt the cold more in my life. However, next morning we started in a little steamer at five o'clock, and passed Fort Opus in the dark; but before we reached Trappano the sun rose, and we had a perfect day. From Trappano we turned back, and, calling at a couple of little ports on the Sabioncello Peninsula, we reached Stagno at half-past ten. Ample time was given us to walk 
across the narrow isthmus and survey the enormous walls which shut it off from the mainlandan old-time natural fortress. At Stagno Grande a rather larger steamer was waiting for us. Unfortunately, it was the eve of the festa of St. Blaise, the patron saint of Ragusa, and the boat was crowded with holiday-makers. At every port more joined us, till there was scarcely standing room, and the hold was crammed with live newly born lambs with their legs tied together, which were handled like parcels-a very cruel method of treatment.

Among other places we called at Luka, in the island of Giupana, and at Cannosa, both of which we had the year before marked down as campingplaces, and very pretty they both would have been. The plane trees of Cannosa are one of the sights of Dalmatia. It has been said that these trees, even more than the palms of Ragusa, remind one of the proximity of the East. Needless to say, they are of great antiquity, perhaps even as old as the celebrated plane trees at Buyukdere, on the Bosphorus, under which Godefroi de Bouillon is said to have rested on his way to the crusades.

From Cannosa we steered back again to Calamotta to pick up more passengers, mostly sea-sick, for there was a considerable "lop" on; and then at last, after a voyage of nearly twelve hours, we reached Gravosa, the port of Ragusa. 
Tired as we were after this long trip, we were so impatient to see the most celebrated Dalmatian town, that we decided to go in there to dinner. We found the inhabitants enjoying the national pastime of walking up and down attired in their best clothes, and we also found what Hans Breitman calls "the hapit of sdaring at sdrangers" very much en evidence.

Next day, however, we saw Ragusa at her best, the celebrated Stradone being decked with Venetian masts, bunting, and flowers, the streets gay with gorgeous native costumes, and the air full of the combined noises of salutes and brass bands.

But for all this, at the risk of being written down a Vandal, I must say that we were disappointed with Ragusa. This perhaps is hardly the fault of the place itself, which, if we had not known Venice, we might have found interesting enough. Unfortunately, in the last two years we had heard so much of it, that our expectations were pitched rather too high, and the old rival of Venice failed to come up to them.

But if the town itself proved disappointing, we were quite surprised and delighted with the Isle of Lacroma, which lies a few furlongs to the south-west of it. The Benedictine convent, originally a Franciscan one, and subsequently the property of two ill-fated Austrian archdukes, 
Maximilian and Rudolf, has this interest for Englishmen-that it was founded by Richard Cour de Lion in pursuance of a vow made under stress of weather in the Adriatic. Otherwise there is not much to see; but the gardens, and above all the wonderful woods of almost subtropical vegetation, are a sight which must be seen to be realized. The island is a paradise for birds, for no gun has been allowed to be fired there for years, and it is consequently one of the few spots in Italian and semi-Italian countries where blackbirds and thrushes are at peace. We were quite sorry to leave its oleanders, palms, oranges, and myrtles, and greatly envied the two friars who are the sole occupants of this delightful domain.

Our two days at Ragusa passed quickly enough, and our last hours were marked by a facetious incident. On receiving my hotel bill I noticed I had been charged for three days' rooms, and mildly protested I had only been there two. The answer was, that our steamer would not be in till midnight, and as they could not let the room to others (they had not had a chance) they must charge me; so I paid. Not an hour afterwards a steamer from the southward came in, and a message was brought up to us: "Would we mind waiting for our boat in a smaller room, as two gentlemen had just arrived, and they had no 
double-bedded room to give them?" Of course we said that, having paid for our room, we intended to have our money's worth; whereupon the money which I had objected to pay was instantly refunded. Nor were we inconvenienced, for our boat arrived rather before her advertised hour of eleven, and when I woke next morning we were at Cattaro.

Cattaro, like Ragusa, perhaps suffers somewhat from the exaggerated descriptions of it which one hears and reads, but the Bocche are undeniably fine. The town itself has little of interest, and when I first gained the deck I could see nothing but the bustling Riva, to which we were made fast, and the tremendous cliffs and precipices up which the endless zigzags of the Cettinje road wind. High up among them stands Fort San Giovanni, and by it is a tremendous mass of rock literally chained to the hillside, to prevent its falling right upon the town. To our right the cliffs fall back a little, and there the Budua road escapes from the valley.

Our time was too limited to allow us to do the sights of Cattaro, which I believe are limited in number. One is the chapel of its patron saint, Trifon, in the cathedral; another the great orange tree which grows in a cave near Fort San Giovanni, whose fruit has never been tasted by mortal man, the spot being quite inaccessible. 
A hawser entangled in the screw delayed our departure, but at last we got off, and were able to enjoy the scenery of the great lough. First came Perasto, with the castle of Santa Croce above it; then Risano, the Roman Rhizinium, and the oldest place in the Bocche di Cattaro, to which it at one time gave the name of Sinus Rhizonicus. Behind it extends the Crivošcie, of evil reputation.

We left the Gulf of Risano to our right, and a sharp turn to the left took us into the Catene, named like those of Sebenico, and for a similar reason. Then we ran for some time towards Castelnuovo, an old place fast coming into repute as a winter resort, by reason of its splendid climate; and then -lunch like a curtain descended over the panorama, and when we again emerged from the saloon. Punta d'Ostro lay behind us, and we had left the Bocche.

Budua-Lestua, and the old Turkish castle of Nehaj, in the Spizza district, all looked picturesque enough that beautiful winter morning, but perhaps "distance lent enchantment to the view." At all events, these were the last points of Austrian land we saw; and then Dalmatia faded from our view, to be but a memory, though, like most memories of travel, a pleasant one, for the inconveniences and drawbacks are readily forgotten, whilst we easily retain recollections of happy days, and of those whose friendship we have made on our journeys, and whom we hope to see again. 


\section{APPENDIX I.}

\section{THE BORA, WHAT IT IS.}

IT was not till the printed sheets of this volume passed through my hands that I realized that, although I had had a good deal to say therein about the bora, I had never said what the bora really is.

In the first place, I am not very sure that I know, often as I have experienced its effects. I have spoken of it, as it is generally spoken of, as a wind, but that I am told it is not. It certainly does not blow from the same quarter in various districts, as the only rule of its being apparently is that its direction is invariably at right angles to the principal mountains in the neighbourhood, and as the trend of these in Dalmatia is generally from north-west to south-east, the general quarter from which the borablows there is from the northeast.

Its range, roughly speaking, appears to be limited to a strip of coast not fifty miles broad, but extending in length from the extreme north of 
the Adriatic to Albania, but its worst effects are experienced in Istria. Such a bor a as we experienced at Mostar in the early part of the year '95, when half the town was unroofed-the new half, that is to say, for the low-lying Turkish houses, with their covering of stone slabs, mostly escaped -is not often known there, and, indeed, is said not to have occurred more than twice since the Austrian occupation.

I have been told that the bora is really a violent down-draught caused by the vast difference between the high temperature of the Adriatic littoral and the low one of the adjacent mountains, and some confirmation of this theory seems to be found in the fact that the bora is said only to continue at Mostar as long as the snow lies on the mountains beyond it. To this I cannot speak personally, for, as has been seen, I was never in Mostar during the summer.

On the other hand, an Austrian naval officer told me they suffered greatly from the bora when lying on the Lower Danube. I am inclined, however, to think that he was confusing it with a very familiar acquaintance of English readersthe east wind. 


\section{APPENDIX II.}

NATURAL HISTORY NOTES.

(1) The chamois being spoken of throughout this book as an antelope, it is just worth noticing, especially in connection with page 234, that it belongs to the group of goat-like antelopes, which is made up (in the old World) by the serow and gooral of the Himalaya, by three (? one) species allied to the first, and by three cemas from Thibet and Amurland, practically unknown to Europeans. The experiment of hybridizing chamois and goats would be most interesting, but is not likely to be tried in England, as there are no chamois in the "Zoo." For this information I am indebted to the artist whose drawings so greatly enhance the interest of this book. Strange to say, when illustrating "Gun, Rifle, and Hound" two years ago, he was confronted with a similar difficulty-there were no roe-deer. This, I think, should not be the case. However unjustly, we have got to look upon the Zoological Society's collection as a national thing; and therefore the 
fauna of our islands should be fully represented. Roe-deer can be bought for, I might almost say, a few shillings.

(2) Like all Indian sportsmen, I have spoken of the "mouse-deer" as if it were a deer. As a matter of fact, it forms a separate group, nearest allied (absurd as it seems) to the camel, and having some affinity with the pig! 


\section{APPENDIX III.}

OUTFIT FOR SPORTSMEN IN THE HERZEGOVINA.

(a) Battery. I would recommend a single $\cdot 400$ Express rifle, and a double 20-bore shot-and-ball gun. A hundred cartridges for the former and five hundred for the latter will be found sufficient. I recommend that both should be fitted with slings, as one often wants both hands, even when only after stone-hens.

(b) Saddlery. Plain hunting-saddle, narrow in the tree, and picketing bridle with suaffle bit. Saddle-bags are useful.

(c) Tents. Out-of-the-way and consequently little-shot-over ground can be reached only by some such tent as I have already spoken of, but much can be done from the gendarmerie posts, especially if a small tent and cot (these can be bought combined) are taken for one or two nights' use. Such an arrangement is far preferable to sleeping in a native kuca.

(d) Clothing. As for deer-stalking in Scotland.

(e) Boots. Highland shoes and spats are the 
best, especially if a pair of tennis-shoes are carried in the rucksack for the actual stalk. N.B.-When wearing these latter, avoid wet places on the rocks.

$(f)$ Seasons. For the best chamois-stalking one should reach Mostar early in August, so as to be on the very highest ground for the opening day (August 18). The chamois will be found high up till the end of September, when the weather is fine and hot. For bear, the best chance is from the middle of April on, according to the season. Wolf and boar always uncertain; for the last Bosnia is better. 
APPENDIX.

\section{APPENDIX IV.}

Recipes For COOKIng stone-hens (Perdix Graca).

No. I.

Truss the bird as if for boiling, and put it into a stewpan with half a pound of streaky bacon cut in squares of about an inch thick, shake in an ounce of flour, and add a clove of garlic. Fry these over the fire until the stone-hen has become brown all over; add two Spanish onions and four ripe tomatoes, two glasses of Tokay, pepper, and salt. Put the lid on and set the sterpan over the fire to cook slowly for about three-quarters of an hour, shaking it occasionally so as to turn the bird about.

Note.-This proportion of bacon is for English ; Herzegovinian being very strong, half the quantity, or even less, will suffice.

\section{No. II.}

Draw two stone-hens, cut off the heads, and truss with a piece of butter inside each, skewering 
the skin of the neck over it. Cut a lemon in slices and lay on the breasts, covering each with a slice of fat bacon. Put the birds in a stewpan, with two carrots, two onions, sliced, and a third stuck with cloves, one glass of Tokay, two bay leaves, thyme, and parsley, and pour over them half a pint of hare soup, made in the usual way. Simmer for one hour, and skim off the fat. Strain the gravy, and thicken with flour and butter. Just before serving, remove the lemon. 


\section{INDEX.}

A

ABsurd description of us in the Dalmatian press, 70

Accidents, 141, 269

- to our tent, 144,383

"Administered Provinces" of 'Turkey, progress in, 192

Almissa, 83 et seq.

Alpine crows, 334

Ancona, 12

Ante, 97

Aqueduct, Roman, 81

Arab horses at Mostar, 168

Archduke Ladislas, H.I.H. the late, 163 223

Arrowhead, stone, 256

Austrian Lloyd steamers, 73, 84, 105

- policy in Dalmatia, 61

A wild-goose chase, 184

\section{$\mathrm{B}$}

BADGERS, 253

Bear, habits of, 220

- beard, 252, 286, 297

shot, 228,252

surprised in his bath, 303

tracks found, 241, 252, 278

Beaters forbidden, 172

Bee-eaters, 253

Bectles, 130, 254

Bettina, 45, 49
Biograd, 35

Biokovo Mountains, 101, 108

Bjelopolje, 221

Blagaj, 163

Blato, Hutovo, 198

- Mostarsko, 162, 183

Boars, unsuccessful search for, 33 et seq., 370

Bocche di Cattaro, 391

Bogumile heresy, 211

tombs, 210, 325, 332

Bokolj, Mount, 24

Botin, 241, 276, 286

Bora in Dalmatia, 4, 27, 47, 93, 108,148

- in the Herzegovina, 197, 371, $383,385,393$

Borke, 349

L Lake, 342

Borovčići, 313

Botanist, a lost, 298

Brazza, island of, 77, 82, 84, 107

Brela, 103

"Bridget M. Malone," 249

Bua, 75

Budua, 392

Buna, 151

\section{C}

Calanotta, 388

Camp, amusements in, 346

- beds, 12,248

- by a cemetery, 43

- by the river, 316

- cookers, 136, 346, 382 
Camp in a frontier fort, 113

$\longrightarrow$ in an old seminary, 87

__ in an olive orchard, 71

__ in a ploughed field, 33

- in a road, 20

- in the forest, 244

- in the snow, 340

- life, comparison between that

in Dalmatia and in the Herzegovina, 245,319

on an islet, 39

- on an old well, 54

- stove, $156,247,319$

-, the last, 373

Campoformio, treaty of, 80

Canale di San Antonio, 50, 54

- di Zara, 28

Cannosa, 388

Capercailzie, 237, 253, 261

Castel Andreis, 64

Castelnuovo, 392

Catene, near Castelnuovo, 392

- near Sebenico, 55

Cattaro, 391

Cervan Mountains, 244

Cesma, 161

Cettina, river, 85 et seq.

Chamois, do they interbreed with goats? 234

- driving, 299 et seq.

- habits of, $284,285,287$

- - horns of, 259, 276, 291, 293

— missed, 263, 267, 276,279, 302

—, my first sight of, 202 shooting with dogs, 323,334 , 352 et seq.

303, 305, 334, 355
shot, 204, $274,277,285,289$,
Chepa, 340, 353
Christian and Moslem peasantry
compared, 312,349
Cippico Palace, 74
Coots, 121
Coral fishery, 57
Crapano, 56
Crivoscie, 8, 392
Crnagora Range, 239 et seq., 313
Curzola, 7 , bear drive in, 243
Cyprus donkeys, 168,170

D

Dachshunds, 5, 72, 139, 140, 261, $277,280,283,297$

Dalmatia described, 7

-, difficulties in camping in, 54

— history of, $7,8,16$

_ inducements to visit, 1,105 , 152

-

-. , railways in, 8,63

- , roads in, 20,41

$\longrightarrow$, routes to, 10

_., water in, $19,57,81$

—, wind in, 47

, wine in, 58,91

Dalmatian dogs, 6

Dandolo, 16

Dhužani waterfalls, 370

"Dinah," 334, 360, 378

Dinaric Alps, 2, 44

Diocletian, 76, 81

"Dorothy," 352, 376, 377

Duare, 91, 103

Dug-outs of the Narenta, 117

Duran, 320, 385

\section{E}

EAGles, 95, 253

Embarrassing curiosity of the natives, 22

Enmity, racial, in Dalmatia, 63 349 , religious, in the Herzegovina,

Establishment, horse-breeding, 166 -, tobacco, 164

Expenses of camp life in Dalmatia, 153

\section{F}

F auna of the Velez, 253

Fenmen of the Narenta marshes, 117

Fezo Zaklan, 340, 352, 377

Fish, 88, 121, 318

Fiume, 108

Flora of the Velez, 255

Fontana, Cavaliere, 55

Food, price of, in Dalmatia, 154

Fort Nicolò, 50 
Fort Opus, 111 et seq., 387 113

"Fox," 375-377

Fox drive near Mostar, 173

Foxes, 139, 253

G

GAćko, a robber shot at, 295

Game sanctuaries, 318, 371

Gendarmerie barracks as resthouses, 236

-, Dalmatian, 18, 34, 145

- Herzegovinian, 296

General Hoffmeister, 228, 301

Giupana, 388

Glavaticevo, camp at, 318

Goat-antelopes, 395

Goats, do they interbreed with chamois? 234

Gooral, 395

Government reserves, 318,371

Gradina, near Morter, 46

$\longrightarrow$, near Opuzen, 115

Gravosa, 388

Ground-sheet stolen, 145

Grušća, 332, 336, 353

- grouse, hazel, 322

Guard of honour supplied us, 34

Gubavica, Mala, 10.

- $\longrightarrow$ Velika, 104

Guzla, the, 185

Gypsies, 110

\section{H}

Hass, or Turkish inns, 185

Haras at Mostar, 166

Hare shooting, 181,374 et seq. by moonlight, 177

"Harmony," 328, 343, 376

Hawks, 111, 253

Hazel grouse, 322

Herzegovina, the, 159 et sey.

- , forests in, 242

-

$\longrightarrow$, Prefect of, 193

- , priests in, 317,347

$\longrightarrow$, roads in, 195
Herzegovina, the, towns of, 159

Hoopoes, 253

Horses, 166 et seq., 311

Hounds, 249, 323

Hum, the, 173

Hut, we build a, 244, 247

Hutovo Blato, 138

Huts, summer, 330, 332, 335

\section{I}

Ixcoronsta, 25, 44, 46

Inglesk, the, in a native canoe, 119

Inns in Dalmatia, 3, 390

Insect episode, an, 130 plagues in camp, $72,88,254$

Insects of the Velez liange, $25 t$

Insurgents, fight with, 315

\section{J}

JACKAI.s in Dalmatia, 2, 25, 102

Jader River, 81

Jagd zum Treibstock, 300

Jam, 256, 322

Jansenića, 163, 173, 175

Jealousy of the Dalmatiaus towards

Bosnia aud Herzegovina, 61

Jesuit college at Spalatro, 78 cousin, a, 4, 75

Jezero, camp by, 243 et seq.

-, water of, 248

Jorrocks quoted, 186, 269, 371, 374,375

Jusié, 137

li

KAPRI, 49

Kasići, 340, 375

Klunj, 311

Knin, 8, 9

Komić, royal luncheou at, 230

Konjića wine, 347,382

Krrka River, 66

- Falls of, 65 et seq.

Krusevicko Polje, 313

Krusevljani, 313

Kušići, 236 
L

LACROMA, 389

Lakat, 237 et seq.

Lämmergeier, 203, 227, 253, 292

Lang, Mr. A., quoted, 364

Ledjenice Hills, 313

Lesina, 7, 82, 109

Lestua, 392

Library, camp, 340

Licence to carry a gun in Dalmatia, 17,101

to carry a gun in the Herzegovina, 171

-, game, in the Herzegovina, 171

Lissa, 69

Ljeljen Mountain, 333

Luka, 388

Luke, 313

Lukomir, 334

\section{M}

Maḱarska, 108

Maligradać, 251, 306

Marshes at Vrana, 42 of the Narenta, 116 et ser.

Martello Tower, 148

Martens, 238, 253

Medjedikuk, 224

Meho Didic, 323

Melada, 13

Metković, 8, 148, 387

Milić, Dom N., 43

Miller, Herr, 197, 202, 227, 385

Mirićhan, 201, 225, 233, 385

Mistletoe, 205, 381

Monks on horseback, 97

Montenegro, 8, 264, 295

Morlaks, 23

- dress of, $23,46,79$

Morter, 44

- , camp at, 43

Mosque, first, seen, 150

- at Glavatičevo, 315

Mosques at Mostar, 163

Mostar, 159 et seq., 385 et seq.

Mouse-deer, 365, 395
$\mathrm{N}$

Narenta, River, 111

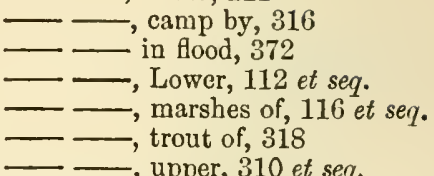

Narentine pirates 123,387

Nehaj, 392

Neum, 138

Nevesinje garrison, 191, 250, 264

Nicolò, Fort, 50, 54

Nomenclature of places in Dalmatia, 79

\section{0}

Orw industry, 58

Oke mouth of the Narenta, 112

Ombla River, 162

Opanke, 125, 179

Opuzen, 111 et seq.

- robbery from our camp at, 145

Osobac Mountain, 316

Outfit for the Herzegovina, 397

Owls, 253, 297

\section{$\mathrm{P}$}

Pack-S addLES, 233, 312, 313

Padežine, 236

Pakoštane, 33

—- camp at, 33

Partridge, Greek. See Stone-hen

- shooting, 180, 294

Pasman, 27

—, camp at, 20 islanders, 23

Passports advisable in Dalmatia, 158

- necessary in Herzegovina, 159

Pelagosas Isles, 73

Peličarić, Mr., 36

Pirates, 80, 108, 123,387

Plancic, Dom N., 43

Perasto, 392

Pigeons, 180

Plague at Pasman, 30

— at Zara, 16 
Poglizza, the, 83

Pola, 10

Powder a Government monopoly, 182

Previčio, 49, 50

Priko, 86 et seq.

Ptarmigan erroneously supposed by author to be found in Dalmatia, 2

Pučisčie, 107

Punta d'Ostro, 392

- Planka, 73

Puppies, 253, 377

\section{Q}

QUAIL shooting in Dalmatia, 37 , 71,118 183,294

Quaint prescriptions, 348

Quarnero, 108

Queer visitor, a, 382

\section{$\mathrm{R}$}

RADo, Signor, 113

Radopolje, 179

Ragusa, 389

Rakitnica, 333, 353

Ravens, 88

Razice, 329

Razića brook, 359

"Rex" 5, 38, 39, 261, 296, 375, 376

Riegeln, 300

Risano, 392

Robbery at Opuzen, 145

Rock-creepers, 253

Roedeer seen, 243, 244, 303, 338, - shot, 196, 205, 364

Rogosnića di Almissa, 108 di Sebenico, 68 et seq. di Sebenico, camp at, 71

Roman bridge at Buna, 151

Ruiste, 235, 384

- Pass, 191, 234, 385

\section{S}

Sabioncello Peninsula, 109, 387

Saint Blaise, 388
Saint John Ursinus, 75

- Justina's Isle, 39

Salona, 80

San Andrea, 69

Antonio, 50

Benedetto, 28

Giorgio di Lesina, 109

Michele, 24

Pietro, 84

Rocco, 44

Sanctuaries for game, 318,371

Sandpipers, 26

Sarica, 236

Scarabæus beetles, 131

Scardona, 66

Scorpions, 72

Sebenico, 55

Sebenico Vecchio, 56

Seminary, a disused, 86

Serow, 395

Servants, camp, 5, 31, 45, 248, 278 , 320

Shark, an imaginary, 90

"Short Stalks" quoted, 288

Snakes, 72, 118, 143, 254

Snipe shooting in Dalmatia, 41, 118,138

- - in the Herzegovina, 180, 197,386

- , solitary, $20 \bar{T}$

Snow in camp, 340

Spalatro, 76 et seq.

Spizza district, 7,392

Sponge fishing, 32,57

Squirrels, 253

Stag, a feral, 127

Stagno, 387

Stags represented on tombstones,211

Starimost, 161

Steamer nearly ashorc, 13

Stepansgrad, 163

Stone-hen shooting in Dalmatia, 97 et seq., 134 et seq.

$181,294,378$

Stone-hens (Perdix Graca) described, 99

- , receipts for cooking, 399

Storms in camp, $26,47,68,22,103$, $144,298,317,371,383$

Stretto, 45,49 
Superstitions of the Morlaks, 31 "Syndic, The," 32

\section{$\mathrm{T}$}

Tenperature in camp, high, 25, 47 - , low, 299, 340, 370

Tent, Austrian military, 305, 307

$\longrightarrow$, our, 20

in ' 95,248

Tkon, 28

'Tobacco culture, 150, 166

- State, factory, 164

Towns of Dalmatia, 9

- of the occupied provinces, 160

'Tragurium, 74

Trappano, 109, 387

Trau, 74

Tre Bocconi, 49

Trieste, 10

"Trieste, The," 105

Tumuli in the Herzegovina, 209

Turks, Herzegovinian, 188, 246, 312,340

'Turkish women in Mostar, 189

- in the country, 189, 344

Tyrolese bulls, 170

\section{U}

Ugliax, 27

Ugly visitor, an, 297

Uninteresting mosques at Mostar, 163

Upper Narenta Valley, 310 et seg.

\section{V}

Velebi't Mountains, 15

Velez Mountains, 232, 309

- — fauna of, 253

-

Velika Poglizza, 307

Velikigradać, 251, 279 et seq.

Venetian rule in Dalmatia, 16

"Venice, The little," 81

Viper, 96, 254

- horned, 254
Visitor, a quaint, 382

$\longrightarrow$, an undesirable, 297

Visočića Mountains, 332

Vissovac, 67

"Vixen," 380

Volcanoes, extinct, 29

Vrana, 36

- , castle at, 37

_- grotto at, 38

_- lake of, 36

- marshes at, 42

Vranjič, 81

Vrulja, 108

Vultures, 163, 253, 292, 334

\section{W}

"WALdMANN," 5, 139, 140

-_, his death, 244

Waterfowl, 40, 64, 87, 121, 184, 198

Weidmann, Der, 1

Widgeon, 40, 42, 253

Wild boar in Dalmatia, 2, 36

370

Wild cats, 102, 253

Woods of the Herzegovina, 340, 242

Woodcock, 179, 342, 345

Woodcraft, 366

Woodpeckers, 253, 367

Wood-pigeons, 253

Wolf at our tent, 297

- drives, 196

- shot by forester, 240

\section{Z}

ZABLAĆE, 51 et seq.

-, camp at, 53

, cave near, 63

Zaborani, 314

Zakusač, 95, 99

Zara, 14 et seq.

Zaravecchia, 35

Zatton, 66

Zeleni Pas, 251, 270 et seq., 284 et seq.

Zimlje, 235, 384

Zlarin, 51

Zoological Society's collection, 395

Zostrog, 109

Zuri, 49 
PRINTED BY WILLIAM CLOWES AND SONS, LIMITED. LONDON AND BECCLES. 

UNIVERSITY OF CALIFORNIA LIBRARY

Los Angeles

This book is DUE on the last date stamped below.

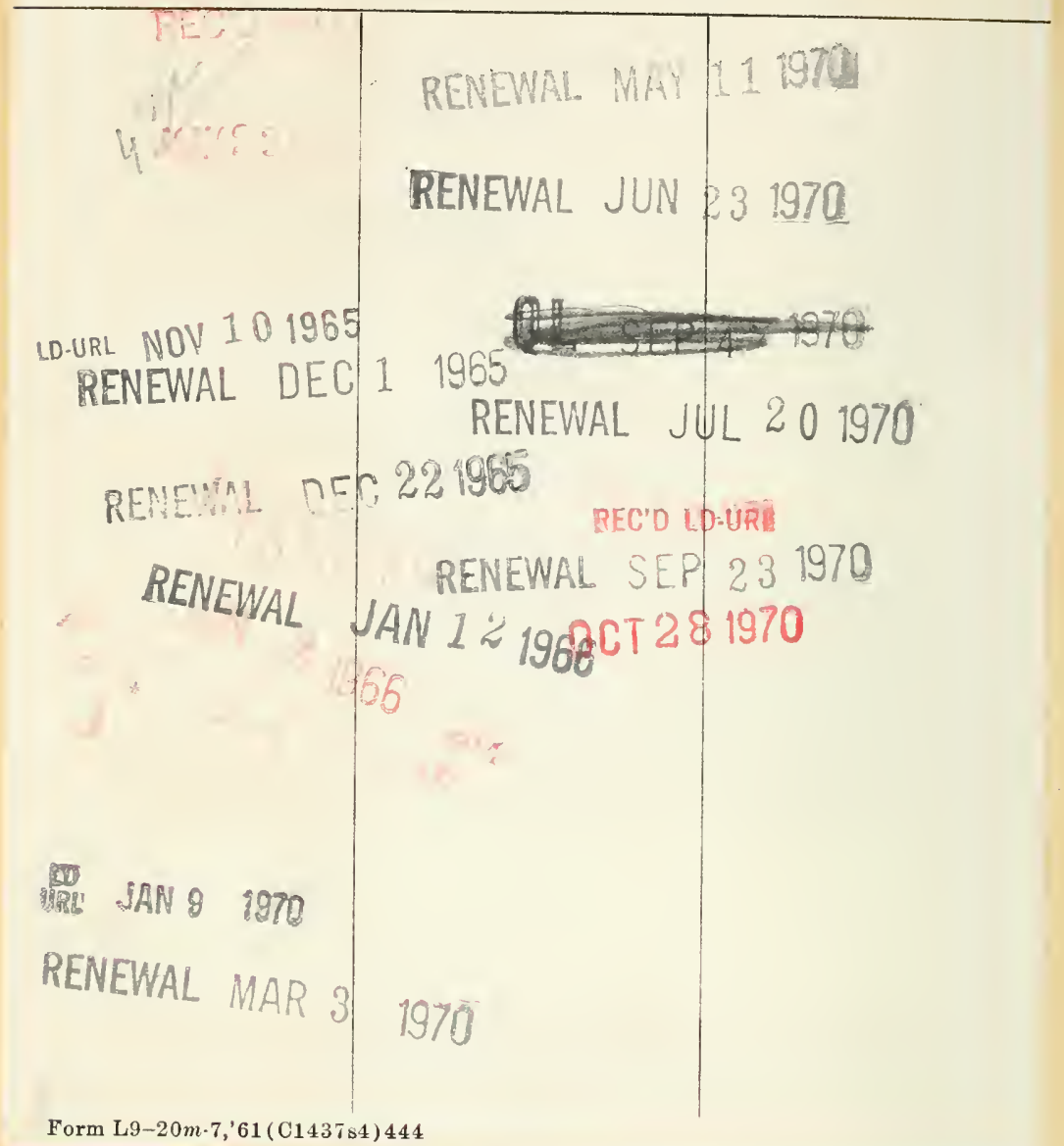

Form L9-20m-7,'61 (C1437ه4) 444 
UC SOUTHERN REGIONAL LIBRARY FACILITY 


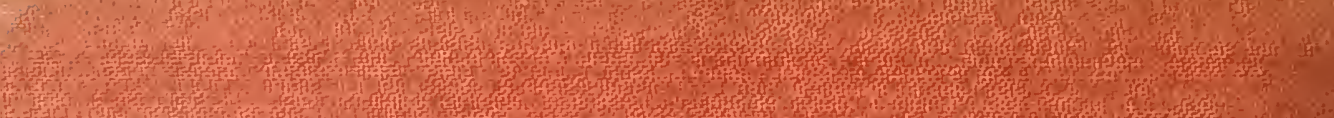

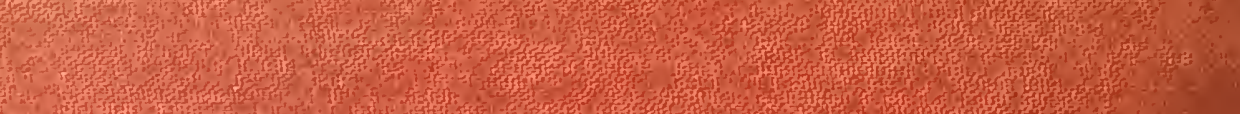

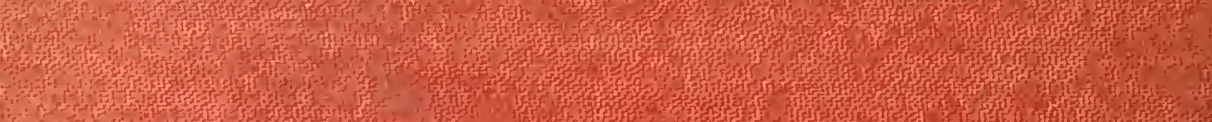
and

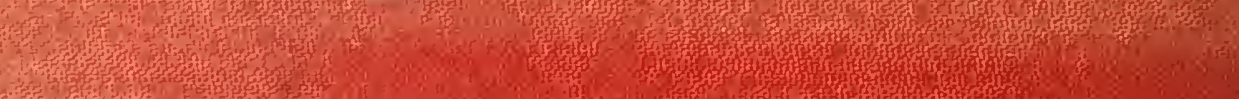
T.1. H. Wh 1
7

H. H. 1470) 1.

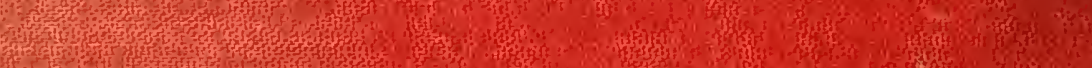
W

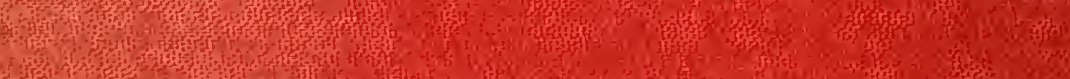

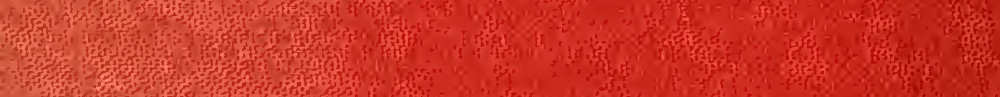
T.

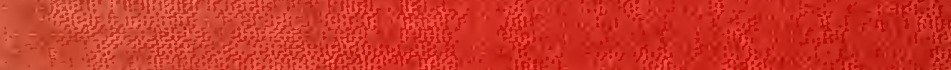
n An

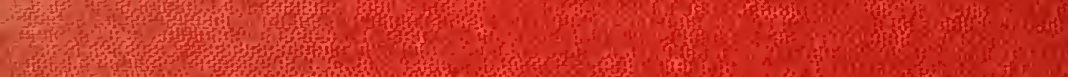
(1),

(x)

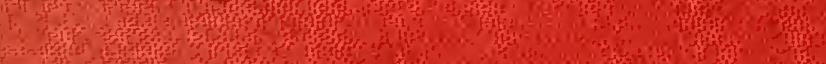

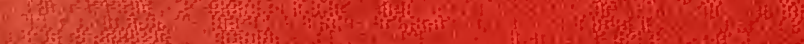
(1)

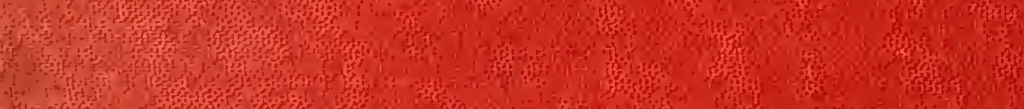

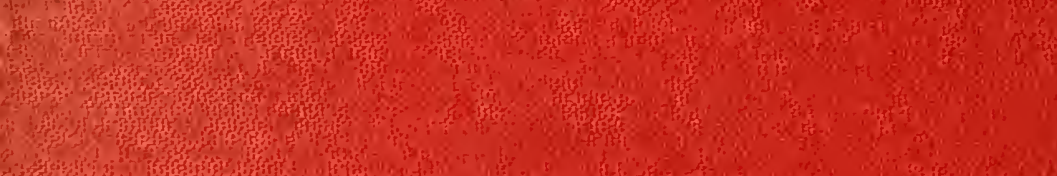
this

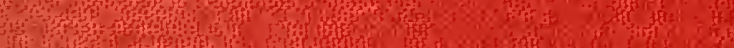
W.1. Q4 W

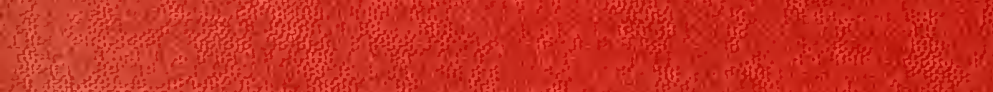
1.

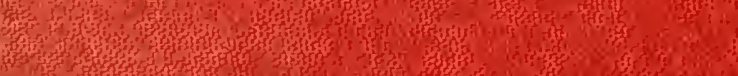

